YUANITA ASGITAMI

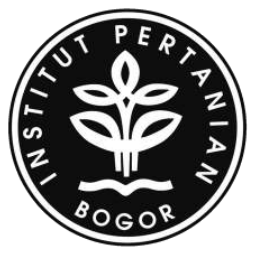

DEPARTEMEN ARSITEKTUR LANSKAP

FAKULTAS PERTANIAN

INSTITUT PERTANIAN BOGOR

BOGOR

2017 


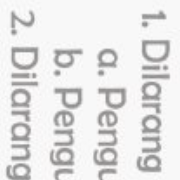

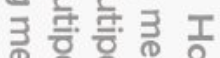

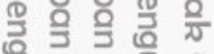

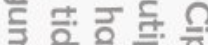

3응올 훙 훙

3 ठ

을 올 을. 을

은 흘. 됭 일 을

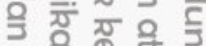

了을 융

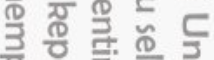

잉

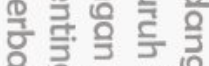

응 장

월

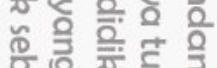

응 兽

을 음 궁

윽 잉

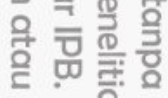

(O)

节

든 일

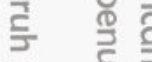

쫄 을

제

空 晃

폴. 을 을

을 글

흘 흘 울

3 융

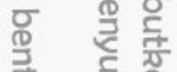

돈 돌

융 을

음 음 항

ᄃ 옹

용

흥 옴

출. 를

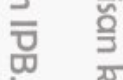

믈

O

율

हैำ

与

호

1

콩 


\section{PERNYATAAN MENGENAI SKRIPSI DAN SUMBER INFORMASI SERTA PELIMPAHAN HAK CIPTA}

Dengan ini saya menyatakan bahwa skripsi berjudul Evaluasi Fungsi Ekologis dan Estetika Pada Beberapa Taman Kota di Jakarta Selatan adalah benar karya saya dengan arahan dari komisi pembimbing dan belum diajukan dalam bentuk apa pun kepada perguruan tinggi mana pun. Sumber informasi yang berasal atau dikutip dari karya yang diterbitkan maupun tidak diterbitkan dari penulis lain telah disebutkan dalam teks dan dicantumkan dalam Daftar Pustaka di bagian akhir skripsi ini.

Dengan ini saya melimpahkan hak cipta dari karya tulis saya kepada Institut Pertanian Bogor.

Bogor, Januari 2017

Yuanita Asgitami A44120006 


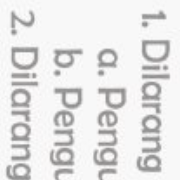

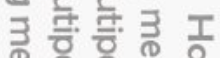

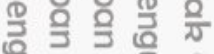

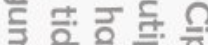

3응올 훙 훙

3 ठ

을 올 을. 을

은 흘. 됭 일 을

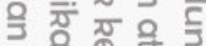

了을 융

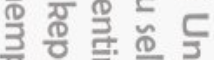

잉

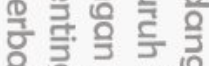

응 장

월

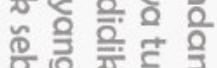

응 兽

을 음 궁

윽 잉

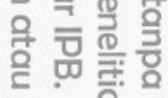

(O)

节

든 일

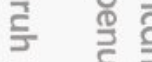

쫄 을

제

空 晃

폴. 을 을

을 글

흘 흘 울

3 융

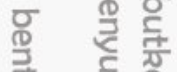

돈 돌

융 을

음 음 항

ᄃ 옹

용

흥 옴

출. 를

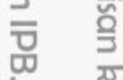

믈

O

율

हैำ

与

호

1

콩 


\author{
ABSTRAK \\ YUANITA ASGITAMI. Evaluasi Fungsi Ekologis Dan Estetika Pada Beberapa \\ Taman Kota Di Jakarta Selatan. Dibimbing oleh TATI BUDIARTI.
}

Taman kota sebagai salah satu jenis ruang terbuka hijau publik yang memiliki peran penting dalam meningkatkan kualitas lingkungan perkotaan. Dua aspek penting yang perlu dalam taman kota yaitu fungsi ekologis dan estetika. Untuk mengetahui sejauh mana pelaksanaan fungsi ekologis dan estetika, perlu adanya evaluasi menyeluruh dari aspek tersebut. Penelitian ini bertujuan untuk mengidentifikasi vegetasi, mengevaluasi pelaksanaan fungsi ekologis dan estetika, danzuntuk mengetahui persepsi serta preferensi pengguna dari lanskap di setiap taman. Penelitian dilaksanakan selama tujuh bulan dan berlokasi di empat taman di Jakarta Selatan, antara lain Taman Ayodya, Taman Martha Tiahahu, Taman Tangkuban Perahu dan Taman Mataram. Metode penelitian ini dibagi menjadi duas metode, evaluasi fungsi ekologis dan evaluasi kualitas estetika di setiap taman. Fungsi ekologis akan dievaluasi dengan membandingkan kondisi yang ada denğ dievaluasi dengan menggunakan metode scenic beauty estimation (SBE) serta preferensi pengguna dan persepsi. Hasil penilaian fungsi ekologis, Taman Tangkuban Perahu terbaik dalam fungsi peredam bising dan penahan angin, Taman Ayodya terbaik dalam modifikasi suhu dan Taman Martha Tiahahu terbaik dalàm fungsi kontrol kelembaban. Penilaian estetika, Taman Ayodya memiliki kuatitas estetika tertinggi dan Taman Tangkuban Perahu memiliki kualitas terendah. Kondisi ekologis yang baik berpengaruh terhadap kondisi estetika taman.

Kata kunci: estetika, evaluasi lanskap, fungsi ekologis, taman kota 


\begin{abstract}
I YUANITA ASGITAMI. The Evaluation of Ecological Function and Aesthetic of City Parks in South Jakarta. Supervised by TATI BUDIARTI.

City park as one type of the public green open space has an important role in improving the environmental quality. There are two important aspects that need to be evaluated within a city park which are its ecological function and aesthetic. In order to know how far the implementation of the ecological function and aesthetic . is required, there need to be a thorough evaluation of these aspects. This study $\subsetneq$ aims to identify the vegetation, evaluate the implementation of ecological function and aesthetic, and also to know user perceptions and preferences of the landscape in each park. This study takes time for seven months and located at four park in South Jakarta namely Ayodya Park, Martha Tiahahu Park, Tangkuban Perahu Park and Mataram Park. The method of this study is divided into two methods, the evaluation of ecological function and the evaluation of aesthetic quality in each park. Ecotogical function will be evaluated by comparing the existing condition with stan' $\overline{\text { dard }}$ criteria for ecological function, while aesthetic quality will be evaluated by using of scenic beauty estimation (SBE) method as well as user preferenees and perceptions. The result of evaluation on ecological function showed that Tangkuban Perahu Park has the best function of noise reductor and wind barier, Ayodya Park has the best function of temperature control, while Martha Tiahahu Park has the best function of humidity control. Based on aesthetic aspect, Agyodya Park is as the highest quality of aesthetic, while Tangkuban Perahu was the lowest quality of aesthetic. Good ecological condition affect the aesthetics condition of the park.
\end{abstract}

Key words: aestethic, city park, ecological function, landscape evaluation 


\title{
EVALUASI FUNGSI EKOLOGIS DAN ESTETIKA PADA BEBERAPA TAMAN KOTA DI JAKARTA SELATAN
}

\section{YUANITA ASGITAMI}

\author{
Skripsi \\ sebagai salah satu syarat untuk memperoleh gelar \\ Sarjana Arsitektur Lanskap \\ pada \\ Departemen Arsitektur Lanskap
}

\author{
DEPARTEMEN ARSITEKTUR LANSKAP \\ FAKULTAS PERTANIAN \\ INSTITUT PERTANIAN BOGOR \\ BOGOR \\ 2017
}




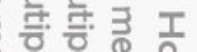

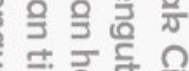

훙흐를 응

गे

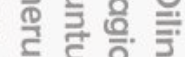

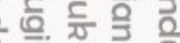

일융융

贾 音

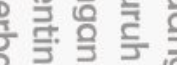

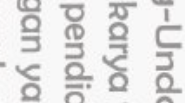

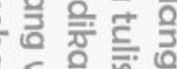

દ을

윽 올

西高要

(C) Hak Cipta Milik IPB, Tahun 2017

Hak Cipta Dilindungi Undang-Undang

Dilarang mengutip sebagian atau kesluruh karya tulis ini tanpa mencantumkan atau menyebutkan sumbernya. Pengutipan hanya untuk kepentingan pendidikan, penelitian, penulisan karya ilmiah, penyusunan laporan, penulisan kritik,atau tinjauan Suatu masalah; dan pengutipan tersebut tidak merugikan kepentingan IPB.

Dilarangmengumumkan dan memperbanyak sebagian atau seluruh karya tulis ini dalam bentuk apa pun tanpa izin IPB. 


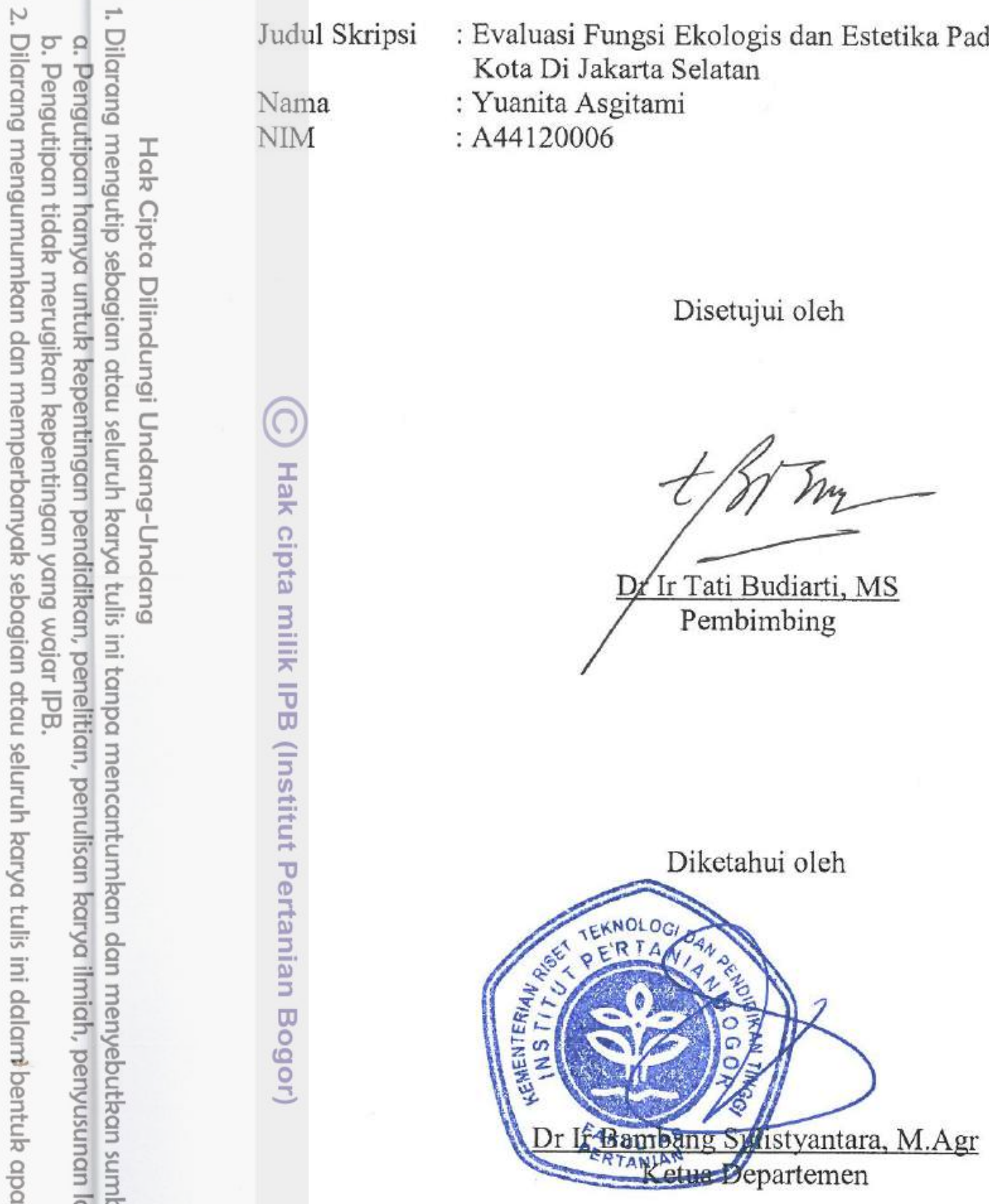




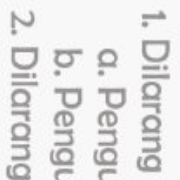

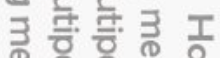

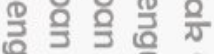

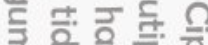

3응올 훙 훙

3 ठ

을 올 을. 을

은 흘. 됭 일 을

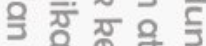

了을 융

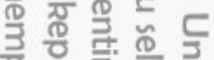

잉

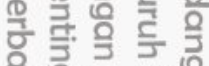

응 장

월

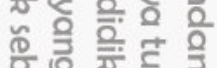

응 兽

을 음 궁

윽 잉

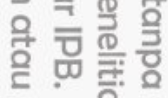

(O)

节

든 일

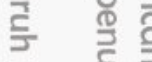

쫄 을

제

空 晃

폴. 을 을

을 글

흘 흘 울

3 융

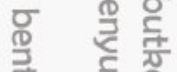

돈 돌

융 을

음 음 항

ᄃ 옹

용

흥 옴

출. 를

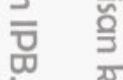

믈

O

율

हैำ

与

호

1

콩 


\section{PRAKATA}

Puji dan syukur penulis panjatkan kepada Allah SWT atas segala karuniaNya sehingga skripsi ini berhasil diselesaikan. Tema yang dipilih dalam penelitian yang dilaksanakan sejak bulan April 2016 sampai Oktober 2016 ini adalah studi tata hijau yang berjudul Evaluasi Fungsi Ekologis dan Estetika Pada Beberapa Taman Kota di Jakarta Selatan.

Pada kesempatan ini, penulis menyampaikan terima kasih kepada:

1. Bapak Sugito, Ibu Yumi Astuti, Wisnu Ary Wardhana dan keluarga besar (Redjawikarta serta keluarga besar Soetomo yang selalu memberi doa, kasih sayang dan semangat dalam setiap langkah hidup penulis;

2. Ilbu Dr Ir Tati Budiarti, MS selaku dosen pembimbing skripsi yang telah banyak memberi arahan kepada penulis selama penyusunan skripsi;

3. ZBapak Prof Dr Ir Wahyu Qamara Mugnisjah, MAgr selaku dosen apembimbing akademik yang telah memberikan bimbingan selama 3 tahun serta pesan-pesan moral yang akan selalu penulis ingat;

4. 三Bapak dan ibu dosen serta staf di Departemen Arsitektur Lanskap yang telah Zanyak memberi kesan kepada penulis selama masa perkuliahan;

5. Keluarga ARL 49 yang telah banyak memberi pengalaman berharga selama 4 ज̆ahun;

6. Pihak-pihak yang turut membantu dan tidak dapat disebutkan satu persatu, baik dalam hal pemikiran, dorongan moral maupun material dalam menyelesaikan penelitian ini.

Penulis menyadari bahwa penulisan skripsi ini masih jauh dari sempurna.

Oleh karena itu, penulis selalu terbuka atas segala kritik dan saran yang bersifat membangun agar dapat menjadi lebih baik lagi di masa mendatang. Semoga skripsi ini bermanfaat.

Bogor, Januari 2017

Yuanita Asgitami 


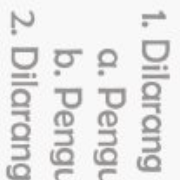

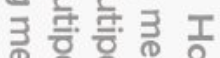

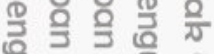

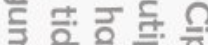

3응올 훙 훙

3 ठ

을 올 을. 을

은 흘. 됭 일 을

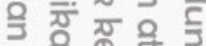

了을 융

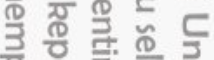

잉

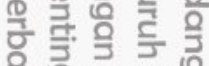

응 장

월

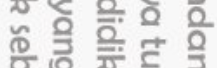

응 兽

을 음 궁

윽 잉

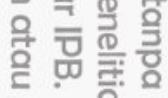

(O)

节

든 일

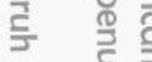

쫄 을

제

空 晃

폴. 을 을

을 글

흘 흘 울

3 융

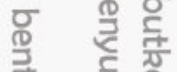

돈 돌

융 을

음 음 항

ᄃ 옹

용

흥 옴

출. 를

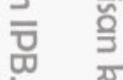

믈

O

율

हैำ

与

호

1

콩 


\section{DAFTAR ISI}

DAFTAR ISI

DAFTAR TABEL

DAFTAR GAMBAR

DAFTAR LAMPIRAN

1 PENDAHULUAN

1.1 Latar Belakang

1.2 Tujuan Penelitian

1.3 Manfaat Penelitian

1.4 Kerangka Pikir Penelitian

2 TINJAUAN PUSTAKA 3

2.1 Ruang Terbuka Hijau 3

$\overline{2} 2$ Taman 4

¿3 Evaluasi 4

2.4 Ekologi 5

2.5 Fungsi Tanaman dalam Lanskap 5

2.6 Estetika $\quad 7$

2.7 Scenic Beauty Estimation (SBE) 7

2.8 Persepsi dan Preferensi

3 METODE 8

3.1 Waktu dan Lokasi Penelitian 8

3.2 Alat dan Bahan 9

3.3 Metode Penelitian 9

3.4 Batasan Penelitian 17

4 KONDISI UMUM 18

4.1 Letak, Luas, dan Batas Lokasi 18

4.2 Keadaan Fisik Taman Ayodya, Taman Martha Tiahahu, Taman

$\begin{array}{lr}- \text { Tangkuban Perahu, dan Taman Mataram } & 18\end{array}$

5 ФASIL DAN PEMBAHASAN 21

5.1 Identifikasi Jenis dan Fungsi Tanaman 21

5.2 Evaluasi Fungsi Ekologis $\quad 24$

5.3 Evaluasi Fungsi Estetika 49

5.4 Persepsi dan Preferensi Responden $\quad 55$

5.5 Rekomendasi Pengembangan Tata Hijau Taman Kota 60

6 SIMPULAN DAN SARAN 63

6.1 Simpulan 63

6.2 Saran $\quad 64$

7 DAFTAR PUSTAKA $\quad 64$

$\begin{array}{ll}\text { RIWAYAT HIDUP } & 94\end{array}$ 


\section{DAFTAR TABEL}

工 1 Bentuk dan jenis data 10

은 2 Kriteria titik pengukuran 11

3 Kriteria penilaian fungsi ekologis 14

4 Baku mutu tingkat kebisingan 16

5 Jenis dan fungsi pohon pada Taman Ayodya 22

6 Jenis dan fungsi pohon pada Taman Martha Tiahahu 22

7 Jenis dan fungsi pohon pada Taman Tangkuban Perahu 23

8 Jenis dan fungsi pohon pada Taman Mataram 24

9 Penilajan aspek fungsi peredam bising di Taman Ayodya 25

10 Rekapitulasi hasil pengukuran tingkat kebisingan di Taman Ayodya 26

11 Penila arian aspek fungsi peredam bising di Taman Martha Tiahahu 26

12 Rekap̄itulasi hasil pengukuran tingkat kebisingan di Taman Martha Tiahăhu

13 Penilaian aspek fungsi peredam bising di Taman Tangkuban Perahu 28

14 Rekapitulasi hasil Pengukuran Tingkat Kebisingan di Taman Tangkikan Perahu

15 Penilaian aspek fungsi peredam bising di Taman Mataram 29

16 Rekapitulasi hasil pengukuran tingkat kebisingan di Taman Mataram 29

17 Persentase penilaian tanaman fungsi peredam bising 30

18 Selisih tingkat kebisingan yang dapat direduksi 31

19 Penilâaian aspek fungsi modifikasi suhu (peneduh) di Taman Ayodya 32

20 Rekapitulasi hasil pengukuran suhu di Taman Ayodya 33

21 Penitaian Aspek Fungsi Modifikasi Suhu (Peneduh) Di Taman Martha Tiahăhu

22 Rekapitulasi hasil pengukuran suhu di Taman Martha Tiahahu

23 Penilaian aspek fungsi modifikasi suhu (peneduh) di Taman Tangkuban Perahu

24 Rekapitulasi hasil pengukuran suhu di Taman Tangkuban Perahu 35

25 Penilaian aspek fungsi modifikasi suhu (peneduh) di Taman Mataram 35

26 Rekapitulasi hasil pengukuran suhu di Taman Mataram 36

27 Persentase penilaian tanaman fungsi modifikasi suhu (peneduh) 36

28 Selisih tingkat modifikasi suhu (peneduh) yang dapat direduksi di taman dengan elemen air

29 Selisih tingkat modifikasi suhu (peneduh) yang dapat direduksi di taman tanpa elemen air

30 Penilaian aspek fungsi kontrol kelembaban udara di Taman Ayodya

32 Penilaian aspek fungsi kontrol kelembaban udara di Taman Martha Tiahahu

33 Rekapitulasi hasil pengukuran kelembaban udara di Taman Martha Tiahahu

34 Penitaian aspek fungsi kontrol kelembaban udara di Taman Tangkuban Perahu

35 Rekapitulasi hasil pengukuran kelembaban udara di Taman Tangkuban Perahu 
37 Rekapitulasi hasil pengukuran kelembaban udara di Taman Mataram

38 Presentasi penilaian tanaman fungsi kontrol kelembaban udara

39 Selisih tingkat kontrol kelembaban udara yang dapat direduksi di taman dengan elemen air

40 Selisih tingkat kontrol kelembaban udara yang dapat direduksi di taman tanpa elemen air

41 Penilaian aspek fungsi penahan angin di Taman Ayodya

42 Penilaian aspek fungsi penahan angin di Taman Martha Tiahahu

43 Penilaian aspek fungsi penahan angin di Taman Tangkuban Perahu

44 Penilaian aspek fungsi penahan angin di Taman Mataram

45. Persentase penilaian tanaman fungsi penahan angin

46 Penilaian THI di Taman Ayodya, Taman Martha Tiahahu, Taman TTangkuban Perahu dan Taman Mataram

\section{DAFTAR GAMBAR}

1 Kerangka pikir penelitian

2 Ëokasi penelitian

3 Penentuan titik pengukuran iklim mikro Taman Ayodya

4 Penentuan titik pengukuran iklim mikro Taman Martha Tiahahu

5 Penentuan titik pengukuran iklim mikro Taman Mataram

6 Penentuan titik pengukuran iklim mikro Taman Tangkuban Perahu

7 (a) Lanskap Taman Ayodya tahun 1950, (b) Peresmian Taman Ayodya Ttahun 2009

8 Kondisi eksisting Taman Ayodya: (a) amfiteater mengarah ke danau dan (b) jogging track

9 KKondisi eksisting Taman Martha Tiahahu: (a) kolam air mancur, (b) Tpatung-patung binatang

10बKondisi eksisting Taman Tangkuban Perahu: (a) lapangan basket dan (b) jogging track

11 Kondisi eksisting Taman Mataram: (a) welcome area dan (b) tanaman hias

12 Persentase persepsi responden tentang kebisingan di (a) Taman Ayodya, (b) Taman Martha Tiahahu, (c) Taman Tangkuban Perahu dan (d) Taman Mataram

13 Persentase persepsi responden tentang suhu udara di (a) Taman Ayodya, (b) Taman Martha Tiahahu, (c) Taman Tangkuban Perahu dan (d) Taman Mataram

14 Persentase persepsi responden tentang kelembaban udara di (a) Taman Ayodya, (b) Taman Martha Tiahahu, (c) Taman Tangkuban Perahu dan (d) Taman Mataram

15 Persentase persepsi responden tentang hembusan angin di (a) Taman

Ayodya, (b) Taman Martha Tiahahu, (c) Taman Tangkuban Perahu dan (d) Taman Mataram

16 Sebaran foto lanskap Taman Ayodya dan klasifikasinya 
18 (a) Lanskap 10 (nilai SBE tertinggi) dan (b) Lanskap 20 (nilai SBE terendah)

19 Sebaran foto lanskap Taman Martha Tiahahu dan klasifikasinya

I 20 Nilai Scenic Beauty Estimation(SBE) setiap foto lanskap Taman Martha Tiahahu

21 (a) Lanskap 6 (nilai SBE tertinggi) dan (b) Lanskap 11 (nilai SBE terendah)

22 Sebaran foto lanskap Taman Martha Tiahahu dan klasifikasinya

23 Nilai Scenic Beauty Estimation(SBE) setiap foto lanskap Taman Tangkuban Perahu

(a) Lanskap 10 (nilai SBE tertinggi) dan (b) Lanskap 1 (nilai SBE terendah)

25 Sebaran foto lanskap Taman Martha Tiahahu dan klasifikasinya

26 Nilaiscenic Beauty Estimation(SBE) setiap foto lanskap Taman Mataram

27 (a) Lănskap 1 (nilai SBE tertinggi) dan (b) Lanskap 17 (nilai SBE terendah)

28 Persentase jenis kelamin responden di (a) Taman Ayodya, (b) Taman Marth̄a Tiahahu, (c) Taman Tangkuban Perahu dan (d) Taman Mataram

29 Persentase tempat tinggal responden di (a) Taman Ayodya, (b) Taman Martha Tiahahu, (c) Taman Tangkuban Perahu dan (d) Taman Mataram

30 Persentase profesi responden di (a) Taman Ayodya, (b) Taman Martha Tiahăhu, (c) Taman Tangkuban Perahu dan (d) Taman Mataram

31 Persentase tujuan responden di (a) Taman Ayodya, (b) Taman Martha Tiahahu, (c) Taman Tangkuban Perahu dan (d) Taman Mataram

32 Persentase persepsi responden terhadap pemandangan di (a) Taman Ayođya, (b) Taman Martha Tiahahu, (c) Taman Tangkuban Perahu dan (d) Tăman Mataram

33 Persentase persepsi responden terhadap penataan elemen taman di (a) Tamân Ayodya, (b) Taman Martha Tiahahu, (c) Taman Tangkuban Perahu dan (d) Taman Mataram

34 Persentase persepsi responden terhadap kebersihan taman di (a) Taman Ayodya, (b) Taman Martha Tiahahu, (c) Taman Tangkuban Perahu dan (d) Taman Mataram

35 Persentase persepsi responden terhadap keindahan kolam di (a) Taman Ayodya dan (b) Taman Martha Tiahahu

36 Persentase preferensi responden terhadap fasilitas di (a) Taman Ayodya dan (b) Taman Martha Tiahahu, (c) Taman Tangkuban Perahu dan (d) Taman Mataram

37 Persentase preferensi responden terhadap aktivitas di (a) Taman Ayodya dan (b) Taman Martha Tiahahu, (c) Taman Tangkuban Perahu dan (d) Taman Mataram

38 Contoh ilustrasi komposisi tanaman pengontrol kelembaban udara berdasarkan hasil pengamatan

39 Contoh ilustrasi tanaman peredam bising berdasarkan hasil pengamatan

40 Contoh ilustrasi komposisi tanaman penahan angin berdasarkan hasil pengamatan

41 Contoh ilustrasi fungsi estetika berdasarkan hasil pengamatan 
42 Contoh ilustrasi tanaman modifikasi suhu (peneduh) berdasarkan hasil pengamatan

\section{DAFTAR LAMPIRAN}

1 Contoh penilaian fungsi ekologis tanaman 66

2 Kuesioner pengunjung Taman Ayodya dan Taman Martha Tiahahu 69

3 Kuesioner pengunjung Taman Tangkuban Perahu dan Taman Mataram 72

4 Kuesioner Scenic Beauty Estimation $\quad 75$

5 Data pengukuran suhu udara maksimum $\left({ }^{\circ} \mathrm{C}\right)$ pertahun di Stasiun Klimatologi

Pondok Betung, Jakarta Selatan 10 tahun terakhir

6 Data pengukuran kelembaban udara (\%) pertahun di Stasiun Klimatologi Pondok Betung, Jakarta Selatan 10 tahun terakhir

7 SHasil pengukuran kebisingan perhari di Taman Ayodya 76

8 Hasil pengukuran kebisingan perhari di Taman Martha TIahahu 76

9 Hasil pengukuran kebisingan perhari di Taman Tangkuban Perahu 77

10 Hasil pengukuran kebisingan perhari di Taman Mataram 77

11 Hasil pengukuran suhu perhari di Taman Ayodya 77

12 $\overline{\text { Hasil pengukuran suhu perhari di Taman Martha Tiahahu }} 78$

13.Hasil pengukuran suhu perhari di Taman Tangkuban Perahu 78

14 Hasil pengukuran suhu perhari di Taman Mataram 79

15 Hasil pengukuran kelembaban udara perhari di Taman Ayodya $\quad 79$

16 Hasil pengukuran kelembaban udara perhari di Taman Martha Tiahahu $\quad 80$

17 Hasil pengukuran kelembaban udara perhari di Taman Tangkuban Perahu 80

18. Hasil pengukuran kelembaban udara perhari di Taman Mataram $\quad 81$

19 Perhitungan nilai SBE Taman Ayodya $\quad 81$

20 Perhitungan nilai SBE Taman Martha Tiahahu $\quad 81$

21 Perhitungan nilai SBE Taman Tangkuban Perahu 82

22.Perhitungan nilai SBE Taman Mataram $\quad 82$

23 F Foto lanskap Taman Ayodya $\quad 83$

24 Foto lanskap Taman Martha Tiahahu $\quad 86$

25 Foto lanskap Taman Tangkuban Perahu 88

26 Foto lanskap Taman Mataram 91 


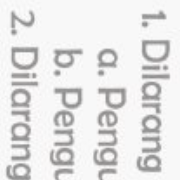

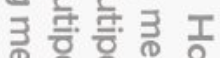

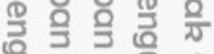

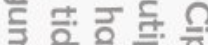

3응올 훙 훙

3 ठ

을 올 을. 을

은 흘. 됭 일 을

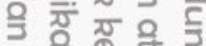

了을 융

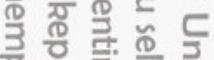

잉

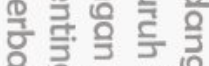

응 장

월

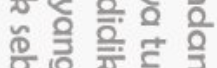

응 兽

을 음 궁

윽 잉

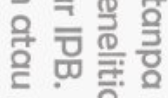

(O)

节

든 일

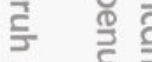

쫄 을

제

空 晃

폴. 을 을

을 글

흘 흘 울

3 융

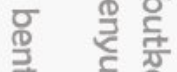

돈 돌

융 을

음 음 항

ᄃ 옹

용

흥 옴

출. 를

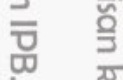

믈

O

율

हैำ

与

호

1

콩 


\section{PENDAHULUAN}

\subsection{Latar Belakang}

Pembangunan perkotaan yang pesat dapat menimbulkan dampak positif dan negatif, terutama terhadap lingkungan. Alih fungsi lahan merupakan dampak negatif pembangunan perkotaan yang menyebabkan kenyamanan kota menurun. Salah satu upaya untuk meningkatkan kembali kenyamanan kota adalah pembuatan ruang terbuka hijau. Ruang Terbuka Hijau (RTH) merupakan salah satio bagian utama dari pembangunan dan pengelolaan ruang-ruang kota dalam upaya mengendalikan kapasitas dan kualitas lingkungannya dan pada saat yang berșamaan juga untuk meningkatkan kesejahteraan warganya (Nurisjah 2005).

Dalam UU RI No. 26 Tahun 2007 tentang penataan ruang telah dijelaskan bahwa proporsi ruang terbuka hijau pada wilayah kota paling sedikit 30 persen darīluas wilayah kota. Namun dalam perkembangannya tidak sedikit kota yang belüm memenuhi proporsi tersebut. Belum tercapainya proporsi RTH di Jakarta Sela्ătan membuat pemerintah setempat harus optimal dan efektif dalam mengembalikan kenyamanan kota salah satunya dengan mengevaluasi taman kota yang sudah ada. Jakarta Selatan sebagai bagian yang tak terpisahkan dari wilayah DKIJ Jakarta menyumbang 25\% RTH untuk DKI Jakarta. RTH di Jakarta Selatan sebănyak 780 buah mencakup 45\% (353 buah) berupa taman. Dengan demikian, tamän-taman di Jakarta Selatan mempunyai pengaruh besar terhadap peningkatan kenyamanan kota Jakarta Selatan.

D Taman kota berfungsi memperbaiki kualitas lingkungan, namun saat ini tamän kota dianggap sebagai suatu pusat kegiatan rekreasi. Penelitian ini dilakukan untuk mengetahui apakah implementasi taman kota sesuai dengan fungsi taman yang sebenarnya. Beberapa taman yang berada di Jakarta Selatan yaitu Taman Ayodya, Taman Martha Tiahahu, Taman Tangkuban Perahu dan Taman Mataram. Keempat taman tersebut dipilih karena mempunyai luas yang hampir sama dan kondisi eksisting taman yang dekat dengan jalan. Keempat taman yang dipilih juga merupakan sample taman untuk melihat perbandingan pengaruh elemen taman yang berbeda (ada dan tidaknya elemen air pada taman).

Taman kota sebaiknya dapat memberi kenyamanan dan kesejahteraan bagi rakyatnya, baik secara jasmani atau rohani dengan memperhatikan dua aspek penting, yaitu fungsi ekologis dan estetika. Fungsi ekologis pada taman sebagai penjaga kualitas dan kestabilan lingkungan kota. Asrinya taman dapat menjadi filter dari kebisingan, pemecah angin dan pengatur iklim mikro. Penelitian terhadap keempat fungsi tersebut karena dapat dirasakan secara langsung oleh pengguna taman. Taman juga harus memiliki nilai estetika karena dapat menjaga dan meningkatkan kebersihan dan keindahan kota. Taman di kota yang indah akan menarik masyarakat sebagai sarana rekreasi dan edukasi, bahkan dapat menjadi daya tarik dan nilai jual bagi kota tersebut. Studi evaluasi tata hijau diperlukan untuk mengetahui apakah penerapan taman sudah memenuhi syarat fungsi ekologis dan estetika serta dapat menjadi pedoman dalam menciptakan suatu lanskap taman kota yang fungsional dan estetik. 


\subsection{Tujuan Penelitian}

I Tujuan penelitian ini antara lain.

1. Mengidentifikasi vegetasi pada Taman Ayodya, Taman Martha Tiahahu, Taman Tangkuban Perahu dan Taman Mataram beserta fungsinya;

2. Mengevaluasi fungsi ekologis dan estetika pada Taman Ayodya, Taman Martha Tiahahu, Taman Tangkuban Perahu dan Taman Mataram;

3. Mengetahui persepsi dan preferensi pengguna taman.

\subsection{Manfaat Penelitian}

Manfaat yang diperoleh dari hasil penelitian ini sebagai salah satu rekomendasi kepada pemerintah daerah dan pihak terkait mengenai penerapan tata $\subsetneq$ hijau taman di Jakarta Selatan, khususnya fungsi ekologis dan estetika.

\subsection{Kerangka Pikir Penelitian}

Jakârta Selatan merupakan salah satu kota yang memiliki banyak RTH berupa taman terbanyak se-DKI Jakarta. Banyaknya taman memiliki pengaruh besar datam mendukung keberlanjutan kota. Terdapat dua aspek yang perlu diperhatikan dalam penerapan taman, yaitu aspek fungsi ekologis dan aspek estetika. Fungsi ekologis yang dianalisis mencakup fungsi peredam bising, modifikasi suhu (peneduh), kontrol kelembaban udara dan penahan angin karena keempat fungsi tersebut dapat dirasakan secara langsung oleh pengguna taman. Nilai estetika menganalisa desain taman dan pemilihan jenis tanaman yang digunakañ. Evaluasi terhadap aspek fungsi ekologis berdasarkan kriteria standar dan aspe $\bar{k}$ nilai estetika dengan metode kuesioner akan menghasilkan deskripsi hasil fungsi ekologis dan deskripsi hasil kualitas estetik. Deskripsi tersebut akan disusun nâenjadi suatu rekomendasi konsep tata hijau untuk taman (Gambar 1). 


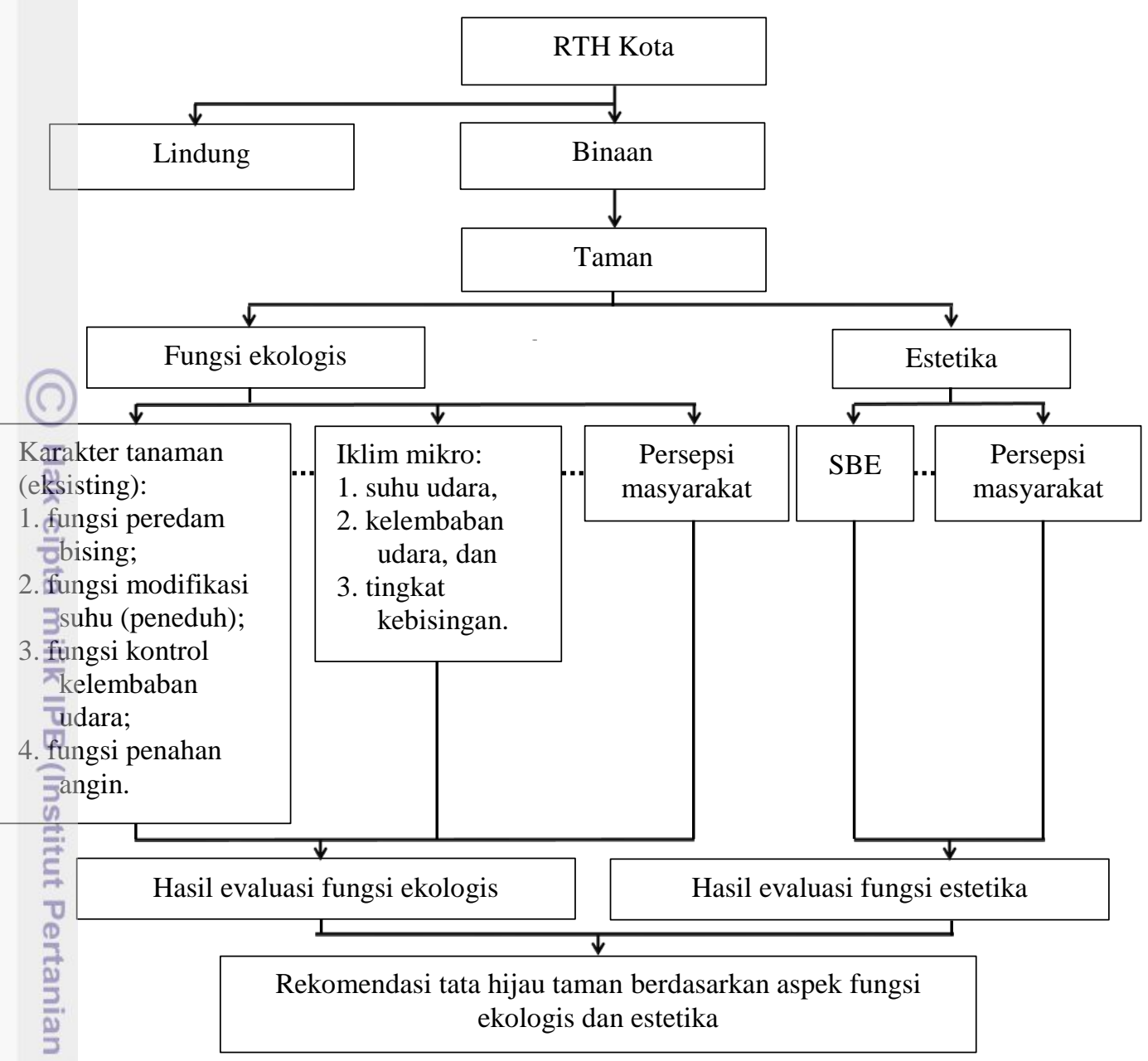

Gambar 1 Kerangka pikir penelitian

\section{TINJAUAN PUSTAKA}

\subsection{Ruang Terbuka Hijau}

Ruang terbuka (open space) adalah segala jenis lahan atau tanah yang tidak ada bangunan diatasnya. Ruang terbuka dibutuhkan (terutama di wilayah perkotaan) untuk memberi keseimbangan pada area yang telah padat oleh bangunan, untuk bergerak dan berekspresi dengan bebas setelah jenuh bekerja. Ruang terbuka terbagi atas ruang terbuka hijau dan ruang terbuka non-hijau. Wujud ruang terbuka hijau dan ruang terbuka non-hijau bisa berupa halaman, lapangan, atau taman kota.

Menurut Undang-Undang RI No.26 Tahun 2007, Ruang Terbuka Hijau (RTH) adalah area memanjang/jalur dan/atau mengelompok, yang penggunaannya lebih bersifat terbuka, tempat tumbuh tanaman, baik yang tumbuh secara alamiah 
maupun yang sengaja ditanam. Ruang Terbuka Hijau Kawasan Perkotaan adalah bagian dari ruang terbuka suatu kawasan perkotaan yang diisi oleh tumbuhan dan I tanaman guna mendukung manfaat ekologi, sosial, budaya, ekonomi dan estetika. Ruang terbuka hijau merupakan salah satu bagian utama dari pembangunan dan pengelolaan ruang-ruang kota dalam upaya mengendalikan kapasitas dan kualitas ? lingkungannya dan pada saat yang bersamaan juga untuk meningkatkan kesejahteraan warganya (Nurisjah 2005).

Fungsi utama (intrinsik) RTH berdasarkan Peraturan Menteri Pekerjaan Umum No.5 Tahun 2008 adalah fungsi ekologis yaitu sebagai pengatur iklim - mikro agar sistem sirkulasi udara dan air secara alami dapat berlangsung lancar, sebagai peneduh, produsen oksigen, penyerap air hujan, penyedia habitat satwa, penyerap zpolutan media udara, air dan tanah serta penahan angin. Fungsi tambahan (ekstrinsik) RTH adalah fungsi sosial dan budaya, fungsi ekonomi dan fungsi estetika. Manfaat ruang terbuka hijau menurut Carpenter, et al. (1975) - sebagai pêlembut suasana keras dari struktur fisik, menolong manusia mengatasi tekanan-tekanan dari kebisingan, udara panas dan polusi di sekitarnya serta sebagai pembentuk kesatuan ruang.

\subsection{Taman}

Laưrie (1986) mengemukakan bahwa asal mula pengertian kata taman (garden) 추 apat ditelusuri pada bahasa Ibrani gan, yang berarti melindungi dan mempertăhankan; menyatakan secara tidak langsung hal pemagaran atau lahan berpagar,@dan oden atau eden, yang berarti kesenangan atau kegembiraan. Jadi dalam bah̆asa Inggris perkataan "garden" memiliki gabungan dari kedua kata-kata tersebut, yang berarti sebidang lahan berpagar yang digunakan untuk kesenangan dan kegembiraan.

Berdasarkan Peraturan Menteri Dalam Negeri No. 1 Tahun 2007 Bab III Pasal 6, Taman kota merupakan salah satu bentuk ruang terbuka hijau kawasan perkotaan. Secara umum, taman kota mempunyai tiga fungsi yang satu sama lain mempunyai keterkaitan diantaranya fungsi ekologis, estetika, dan fungsi sosial. Fungsi ekologis memposisikan taman kota sebagai penyerap dari berbagai polusi yang diakibatkan oleh aktivitas penduduk, seperti meredam kebisingan dan menyerap kelebihan $\mathrm{CO}_{2}$ untuk kemudian mengembalikan menjadi $\mathrm{O}_{2}$. Selain itu, taman kota menjadi tempat untuk melestarikan berbagai jenis tumbuhan dan hewan. Fungsi estetik taman kota dapat mempercantik estetika sebuah kota, terutama dengan mempertahankan keasliannya. Fungsi sosial taman kota menjadi tempat berbagai macam aktivitas sosial seperti berolah raga, rekreasi, dan diskusi.

\subsection{Evaluasi}

Arifin et al. (2008) menyatakan bahwa evaluasi adalah suatu proses untuk menaksir kinerja dan keluaran yang dihasilkan oleh suatu program. Evaluasi pada suatu taman adalah menguji kesesuaian kondisi taman dengan rencana/rancangan taman dan kualitas yang standar serta pengelolaannya untuk perencanaan mendatang. Mekanisme evaluasi ini dilengkapi dengan perangkat pedoman (toolkit) yang meliputi standar prosedur operasi atau standard operating 
procedure (SOP) beserta indikator dan kriteria standar. Evaluasi dilakukan untuk menentukan keputusan apakah akan melanjutkan suatu program yang dinilai sukses atau apakah akan menghentikannya. Tujuan evaluasi adalah untuk mengkoleksi dan menampilkan informasi yang diperlukan dalam mendukung pengambilan kesimpulan dan keputusan tentang suatu program serta nilainya. Hasil evaluasi digunakan untuk membantu memutuskan apakah suatu program akan dilanjutkan atau dihentikan dan bagaimana cara pengembangannya (Hidayat 2010).

Pada hakekatnya, evaluasi diyakini sangat berperan dalam upaya meningkatkan kualitas operasional suatu program dan berkontribusi penting dalam memandu pembuat kebijakan di seluruh strata organisasi. Dengan menyusun desain evaluasi yang baik dan menganalisis hasilnya dengan tajam, kegiatan evaluasi dapat memberi gambaran tentang bagaimana kualitas operasional program, layanan, kekuatan dan kelemahan yang ada, efektivitas biaya serta arah produktif yang potensial untuk masa depan (Hidayat 2010).

\subsection{Ekologi}

Ekologi berasal dari bahasa Yunani yaitu oikos yang berarti rumah atau tempat untuk tinggal sedangkan logos berarti ilmu. Secara umum, ekologi didẹnisikan sebagai ilmu yang mempelajari hubungan timbal balik antara organisme dan lingkungannya (Forman dan Gordon 1986). Berdasarkan Peraturan Meñteri Dalam Negeri No. 1 Tahun 2007, ekologis adalah hubungan timbal balik antara kelompok organisme dan lingkungannya.

Catenese dalam Sembiring (2005) menyatakan fungsi ruang terbuka hijau sebagai ekologis akan memberikan keseimbangan ekologis untuk mencegah polüsi udara di perkotaan melalui unsur vegetasi yang beragam. Menurut Carpenter et al. 1975, fungsi tanaman pada ruang terbuka hijau yang berfungsi sebâgai ekologis adalah pengendali iklim dan pencegah erosi. Pengendali iklim untuk kenyamanan manusia dengan faktor yang mempengaruhi seperti suhu, radiasi sinar matahari, angin, kelembaban, suara dan aroma.

\subsection{Fungsi Tanaman dalam Lanskap}

Booth (1983) mengemukakan bahwa tanaman memiliki tiga fungsi utama dalam lingkungan perkotaan yaitu fungsi struktural, fungsi lingkungan, dan fungsi visual. Fungsi lingkungan dapat dikatakan juga sebagai fungsi ekologis. Tanaman memiliki peranan penting yang berpengaruh pada kehidupan manusia baik secara langsung maupun tidak langsung. Fungsi-fungsi tanaman menurut Grey dan Deneke (1978), Booth (1983), dan Carpenter et al. (1975) antara lain meliputi perbaikan iklim, bidang teknik, bidang arsitektur, nilai estetik, dan habitat kehidupan liar. Agar dapat memenuhi fungsi-fungsi ekologis tanaman, terdapat béberapa kriteria yang harus diperhitungkan, yaitu:

\subsubsection{Peredam Bising}

Efektifitas tanaman dalam mengontrol kebisingan tergantung pada tinggi tanaman, kepadatan daun, dan jarak penanaman. Laurie (1986) menyatakan 
bahwa kemampuan tanaman dalam mereduksi kebisingan tergantung dari ukuran dan kerapatan daun. Laurie (1986) juga menyatakan bahwa penanaman pohon dan I semak dapat mengurangi tingkat kebisingan diudara. Kebisingan dapat direduksi Whingga $10 \mathrm{~dB}$ pada jalur yang tersusun dari pohon yang tinggi dan rimbun. - Semakin dekat tanaman ke sumber kebisingan akan semakin efektif tanaman 2 tersebut dalam meredam bising. Tingkat kebisingan yang dapat direduksi oleh tanaman juga dipengaruhi oleh intensitas, frekuensi, dan arah suara (Carpenter et al. 1975)

\section{으. 2.5.2 Modifikasi Suhu (Peneduh)}

Suht lingkungan sangat dipengaruhi oleh radiasi matahari, untuk itu diperlukan tanaman sebagai media penangkap radiasi untuk menurunkan suhu lingkungān. Efektifitas tanaman dalam menangkap radiasi matahari tergantung pada kepâdatan daun, bentuk daun, dan pola percabangan (Grey dan Deneke 1978). Sepperti yang dikatakan Simonds (1983) pohon yang memiliki batas kanopi tinggi be dapat menghalangi sinar matahari dan menurunkan suhu lingkungan yaitu bertajuk febar, bentuk daun lebar, dan memiliki ketinggian kanopi lebih dari 2 meter.

\subsubsection{Pengontrol Kelembaban Udara}

Grey dan Deneke (1978) menyatakan kriteria tanaman yang dapat menangkap jatuhnya air hujan dan mengontrol pergerakan air ke tanah adalah tanaman berdaun jarum atau berdaun kasar (berambut), pola percabangan horizontał dan tekstur batang yang kasar. Tanaman dapat mengontrol kelembaban udara dengan melakukan transpirasi, yaitu melepaskan uap air ke udara. Semakin banyak jumlah daun maka semakin banyak jumlah uap air yang dikeluarkan, dengan demikian kelembaban udara semakin tinggi (Carpenter et al. 1975).

\subsubsection{Penahan Angin}

Salah satu cara memanipulasi kecepatan angin yaitu dengan keberadaan tanaman yang dapat menghalangi atau membelokkan arah angin. Komposisi tanaman yang berbeda ketinggian mampu mengurangi kecepatan angin sekitar 4050\% (Carpenter et al. 1975). Grey dan Deneke (1978) menyatakan bahwa tingkat proteksi suatu area terhadap angin tergantung pada ketinggian tanaman. Beberapa kriteria tanaman sebagai penahan angin menurut Dahlan (1992), antara lain: (1) memiliki dahan yang kuat namun cukup lentur; (2) daunnya tidak mudah gugur oleh terpaan angin yang agak kuat; (3) tajuk tidak terlalu rapat dan juga tidak terlalu jarang. Tajuk yang terlalu rapat akan mengakibatkan terbentuknya angin turbulen, sedangkan tajuk yang terlalu jarang tidak dapat berfungsi sebagai penahan angin. Kerapatan tanaman yang ideal antara 75-85\%; (4) tinggi tanaman harus cukup, agar dapat bekerja sebagai pelindung dengan baik. 


\subsection{Estetika}

Estetika merupakan istilah yang erat kaitannya dengan keindahan. Estetika dapat didefinisikan sebagai suatu kondisi persepsi pasca indera yang dapat menggugah perasaan seseorang (Porteous 1983). Simonds (1983) menyatakan estetika merupakan hubungan yang harmonis dari semua elemen atau komponen yang dirasakan. Estetika dalam lanskap dapat berarti suatu keindahan yang dapat mempengaruhi kualitas suatu lingkungan dan merupakan salah satu sumber daya alam (SDA) sehingga perlu dilestarikan dan ditingkatkan kualitasnya.

Manusia pada umumnya menyukai keindahan, untuk itu manusia senantiasa menjadikan lingkungannya tetap indah (Heath 1988). Salah satu upaya yang dilakukan manusia adalah perlindungan terhadap kualitas keindahan lingkungan. Kualitas estetika suatu lanskap secara langsung dapat memberikan kepuasan pada seseorang, dan secara tidak langsung dapat mempengaruhi perilaku manusia. Kuălitas estetika mempunyai kontribusi dalam membentuk karakter dan identitas suatu tempat (Heath 1988). menurut Nassar (1988) komponen dari suatu objek dalam menentukan tingkat estetikanya dapat ditentukan melalui dua penilaian, yaitū formal dan simbolik. Estetika formal menilai suatu objek berdasarkan bentetk, ukuran, warna, kompleksitas, dan keseimbangan suatu objek. Sedangkan estetika simbolik menilai suatu objek berdasarkan pada makna konotatif dari objekk tersebut setelah dialami oleh pengamat.

\subsection{Scenic Beauty Estimation (SBE)}

Menurut Daniel dan Boster (1976) keindahan pemandangan lanskap mefupakan salah satu sumber daya alam yang sangat penting. Secara objektif kein̄dahan pemandangan sulit diukur karena bersifat kualitatif, namun dengan menggunakan metode Scenic Beauty Estination (SBE) penilaian secara kualitatif tersebut dapat ditransformasikan menjadi nilai kuantitatif. Metode SBE adalah suatu metode pendugaan keindahan pemandangan yang dikembangkan oleh Daniel dan Boster, yang merupakan model paling dikenal untuk evaluasi lanskap (Bergen 1993).

Scenic Beauty Estimation (SBE) merupakan suatu metode untuk menilai suatu lanskap atau objek lanskap berdasarkan keindahan yang disukai. Metode ini menggunakan kuesioner untuk mengetahui preferensi masyarakat terhadap suatu lanskap tertentu. Penerapan metode SBE terdiri dari tiga langkah utama, yaitu pengambilan foto lanskap, presentasi slide foto, dan analisis data (Daniel dan Boster 1976). Metode SBE mengukur preferensi masyarakat dengan penilaian melalui sistem rating dengan skala 1-10 terhadap slide foto. Menurut Kaplan (1988) penilaian manusia terhadap pemandangan melalui foto sama baiknya dengan menilai pemandangan secara langsung.

\subsection{Persepsi dan Preferensi}

Kata persepsi menurut Kamus Besar Bahasa Indonesia didefinisikan sebagai proses seseorang mengetahui beberapa hal melalui panca indera. Porteous (1977) mendefinisikan persepsi sebagai suatu respon berbentuk tindakan yang 
dihasilkan dari kombinasi faktor internal manusia dengan faktor eksternal yaitu keadaan fisik dan sosial. Persepsi tiap individu dapat berbeda. Eckbo (1964) I berpendapat bahwa persepsi dipengaruhi oleh latar belakang intelektual dan pengalaman emosional, pergaulan dan sikap seseorang. Semakin dalam latar - belakang intelektual dan semakin banyak pengalaman emosional yang dialami 2 seseorang akan sangat mempengaruhi kedalaman persepsinya terhadap suatu objek.

Preferensi didefinisikan sebagai suatu tindakan untuk memilih yang ditentukan oleh banyak faktor. Faktor yang mempengaruhi preferensi masyarakat . terhadap suatu kualitas visual lanskap ditentukan baik kualitas lanskap tersebut maupun keadaan psikologi masyarakat yang mengamati (Permata, 2002). Menurut Abello dan Bernaldez (1986) faktor-faktor yang mempengaruhi preferensi masyarakât antara lain usia, jenis kelamin, tingkat sosial, tingkat pendidikan dan budaya. Ereferensi juga dipengaruhi oleh rasa keterkaitan seseorang terhadap suatu tempat selama ia biasa hidup atau tinggal lama didalamnya. Dengan kata lain preferensi seseorang dipengaruhi juga oleh rasa familiaritas (Nassar, 1988).

\section{METODE}

\subsection{Waktu dan Lokasi Penelitian}

Këgiatan penelitian ini berlangsung selama 7 bulan sejak bulan April sampai Oktober 2016. Penelitian dilaksanakan di beberapa taman di Jakarta Selatan yaitu Taman Ayodya, Taman Martha Tiahahu, Taman Tangkuban Perahu dan Tamån Mataram. Taman Ayodya terletak di Jalan Barito, Kel. Kramat Pela, Kec. Kebäyoran Baru. Taman Martha Tiahahu terletak di Jalan Sisingamangaraja, Kel. Melawai, Kec. Kebayoran Baru. Taman Tangkuban Perahu terletak di Jalan Tangkuban Perahu, Kel. Guntur, Kec. Setia Budi. Taman Mataram terletak di Jalan Mataram Raya, Kel. Selong, Kec. Kebayoran Baru. Empat lokasi dipilih karena memiliki luas area yang hampir sama dan kondisi eksisting taman yang dekat dengan jalan. Keempat taman yang dipilih juga merupakan sample taman untuk melihat perbandingan pengaruh elemen taman yang berbeda (ada dan tidaknya elemen air berupa kolam pada taman). Ada atau tidak adanya elemen air dapat membantu mengetahui efektifitas dalam mengontrol iklim mikro. Peta lokasi penelitian dapat dilihat pada Gambar 2. 


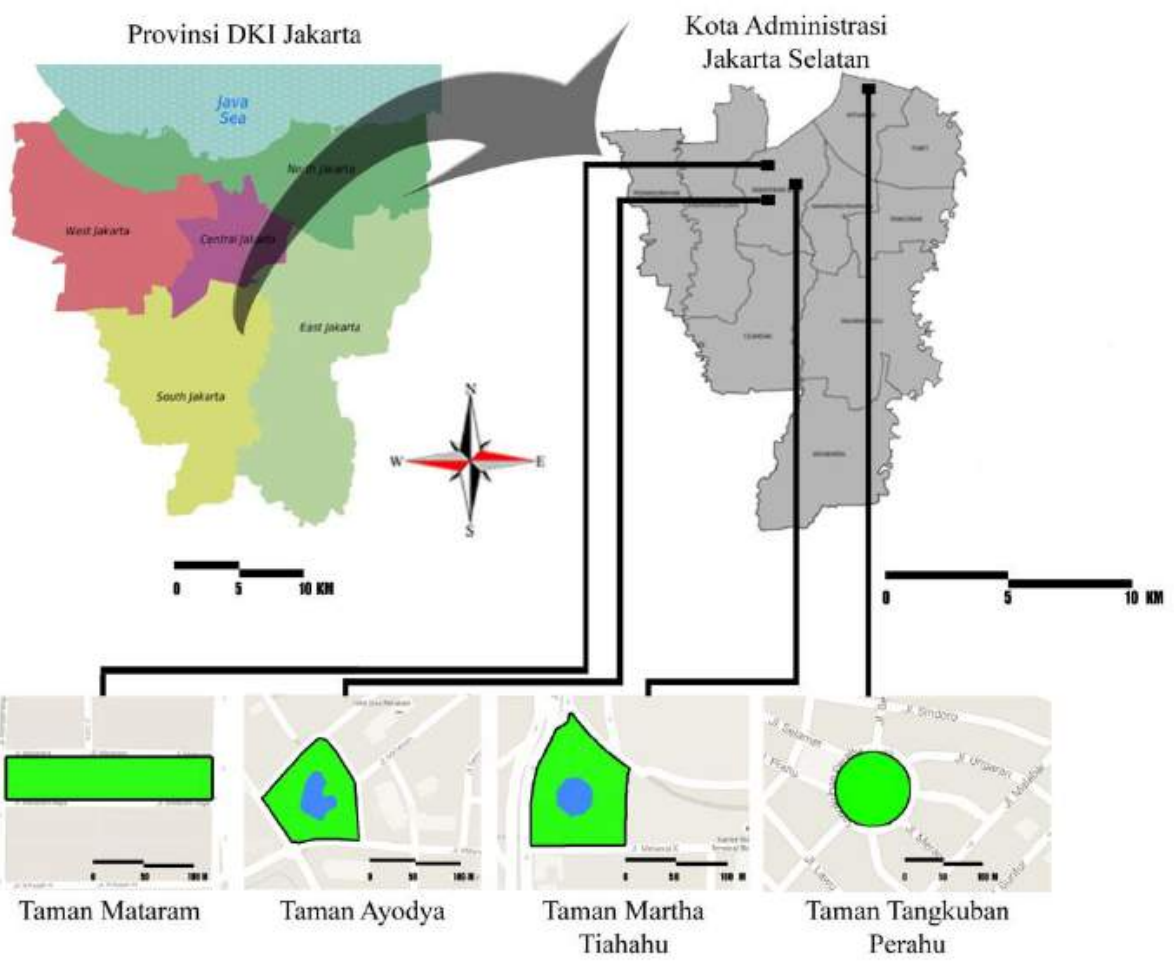

Sumber: Google maps 2016

Gambar 2 Lokasi penelitian

\subsection{Alat dan Bahan}

Bahan yang digunakan dalam penelitian ini adalah peta Taman Ayodya, Tannan Martha Tiahahu, Taman Tangkuban Perahu dan Taman Mataram, survey sheet, dan kuesioner. Alat yang digunakan adalah kamera untuk pengambilan gambar, Thermo Hygrometer Digital untuk mengukur suhu dan kelembaban, Sound Level Meter untuk mengukur tingkat kebisingan, dan software untuk mengolah data dan gambar seperti Microsoft Office dan Excel 2010, autoCAD 2013 dan Adobe Photoshop CS3.

\subsection{Metode Penelitian}

Studi ini menggunakan dua metode, yaitu evaluasi terhadap aspek fungsi ekologis dan evaluasi terhadap kualitas estetika Taman Ayodya, Taman Martha Tiahahu, Taman Tangkuban Perahu dan Taman Mataram. Penelitian ini mengacu pada penelitian yang dilakukan oleh Wungkar (2005) dengan beberapa modifikasi. Pengumpulan data dilakukan dengan cara pengamatan di lapang, wawancara dengan pihak terkait, penyebaran kuesioner, dan studi literatur. Data yang dibutuhkan mencakup data fisik dan biofisik, data iklim, data letak geografis, tata guna lahan, dan data sosial ekonomi. Penelitian ini dilakukan dengan tahapan kerja meliputi tahapan persiapan, inventarisasi, evaluasi, dan penyusunan rekomendasi. 


\subsubsection{Tahap Persiapan}

Tahap persiapan merupakan tahap awal sebelum penelitian dimulai atau 응 disebut dengan tahap prasurvei yang meliputi kegiatan penentuan lokasi ? penelitian, pembuatan proposal usulan penelitian, konsultasi dengan pembimbing, - pengumpulan data sekunder, studi pustaka dan literatur, serta mengurus perizinan kepada instansi yang terkait. Pada tahap ini, studi literatur bertujuan untuk mengetahui kondisi secara umum tapak yang akan diamati sebelum turun ke L lapangan secara langsung. Selain itu, untuk mengetahui potensi dan kendala pada tapak yang akan diamati sehingga mempermudah ketika mengambil data.

\subsubsection{Tahap Inventarisasi}

Tahă inventarisasi merupakan tahapan pengumpulan data dan informasi $\subset$ terkait tapak yang mendukung penelitian. Pada tahap ini dilakukan pengumpulan data primer dan data sekunder. Data primer diperoleh melalui pengamatan dan pengukurân secara langsung pada tapak, pemotretan dan penyebaran kuesioner kepada responden. Data sekunder diperoleh melalui pencarian data di dinas terkait dan pengêtimpulan studi pustaka dan literatur.

Jenis data yang dibutuhkan dalam tahap ini mencakup data letak geografis, vegetasi, iklim, kebisingan, dan persepsi masyarakat (Tabel 1). Metode pengambi $\overline{\text { Han }}$ data menggunakan teknik survei dan studi pustaka. Survei meliputi pengamatạn langsung, pengambilan dokumentasi dan penyebaran kuesioner kepada responden. Studi pustaka dilakukan dengan mencari data dari buku acuan, data informasi, jurnal, dan dokumen dari instansi pemerintah yang terkait.

Padā tahap ini dilakukan pengukuran iklim mikro (suhu dan kelembaban udara) dân tingkat kebisingan yang dibutuhkan sebagai bahan analisis dan penilaian Selain itu, dilakukan juga pemotretan foto lanskap pada masing-masing taman kota sebagai bahan kelengkapan kuesioner. Penyebaran kuesioner akan dilakukano dua tahap, kepada pengunjung masing-masing taman kota sebanyak 30 kuesioner secara purposive sampling dan kepada responden khusus yaitu 30 mahasiswa Departemen Arsitektur Lanskap IPB semester 4 dan 8 yang telah mengambil MK. Teori Desain Lanskap.

Tabel 1 Bentuk dan jenis data

\begin{tabular}{|c|c|c|c|}
\hline Jenis Data & Parameter & Bentuk Data & Sumber Data \\
\hline Letak geografis & $\begin{array}{l}\text { Batas wilayah } \\
\text { Luas wilayah }\end{array}$ & $\begin{array}{l}\text { spasial - } \\
\text { deskriptif }\end{array}$ & $\begin{array}{l}\text { Dinas Pertamanan dan Pemakaman } \\
\text { DKI Jakarta }\end{array}$ \\
\hline Vegetasi & $\begin{array}{l}\text { Sebaran } \\
\text { vegetasi } \\
\text { Jumlah vegetasi } \\
\text { Jenis vegetasi }\end{array}$ & $\begin{array}{l}\text { spasial- } \\
\text { deskriptif }\end{array}$ & Survei lapang \\
\hline Iklim mikro & $\begin{array}{l}\text { Suhu udara } \\
\text { Kelembaban } \\
\text { udara }\end{array}$ & Deskriptif & $\begin{array}{l}\text { Survei lapang (Thermo } \\
\text { Hygrometer) - Badan Meteorologi, } \\
\text { Klimatologi dan Geofisika }\end{array}$ \\
\hline Kebisingan & $\begin{array}{l}\text { Baku mutu } \\
\text { Kebisingan }\end{array}$ & $\begin{array}{l}\text { spasial- } \\
\text { deskriptif }\end{array}$ & Survei lapang (Sound Level Meter) \\
\hline
\end{tabular}


Tabel 1 Bentuk dan jenis data (lanjutan)

\begin{tabular}{llll}
\hline Jenis Data & \multicolumn{1}{c}{ Parameter } & Bentuk Data & \multicolumn{1}{c}{ Sumber Data } \\
\hline Penahan Angin & $\begin{array}{l}\text { Jenis vegetasi } \\
\text { Tinggi vegetasi }\end{array}$ & $\begin{array}{l}\text { spasial- } \\
\text { deskriptif }\end{array}$ & Survei lapang \\
Kensepsi dan & Kenyamanan & deskriptif - & Survei lapang (Kuesioner) \\
Preferensi & Estetika & kualitatif & \\
masyarakat & & & \\
\hline
\end{tabular}

a Pengukuran Iklim Mikro (Suhu dan Kelembaban Udara)

Data suhu dan kelembaban udara dibutuhkan sebagai bahan pembanding untuk penilaian fungsi ekologis. Pengukuran ini dilakukan di dalam dan di luar taman, tujuannya adalah mengetahui efek fungsi taman kota sebagai pengontrol suhü perkotaan. Masing-masing taman dibagi menjadi empat segmen pengukuran, masing-masing segmen diambil beberapa titik pengukuran. Berikut adalah tabel kriteria titik pengukuran.

Tabel 2 Kriteria titik pengukuran

\begin{tabular}{ll}
\hline Elemen Taman & \multicolumn{1}{c}{ Titik Pengukuran } \\
\hline Taman memiliki elemen air & 1. Di atas rumput tanpa naungan \\
& 2. Di atas perkerasan tanpa naungan \\
& 3. Di atas rumput di bawah naungan pohon \\
& 4. Di atas rumput tanpa naungan dekat air \\
& 5. Di atas perkerasan tanpa naungan dekat air \\
& 6. Di atas rumput dibawah naungan pohon dekat air \\
1. Di atas rumput tanpa naungan \\
2. Di atas perkerasan tanpa naungan \\
\end{tabular}

Sumber: Mahardi 2013 dengan modifikasi

Cara pengukuran dengan mencatat suhu dan kelembaban udara maksimum setiap 20 detik sekali selama satu menit. Pengukuran dilakukan saat pagi pukul 08.00-09.00, siang pukul 13.00-14.00, dan sore hari pukul 16.00-17.00 pada keempat taman tersebut saat cuaca cerah. Pada setiap waktu pengukuran dilakukan tiga kali pengulangan pada hari yang berbeda hingga didapatkan suhu dan kelembaban udara rata-rata. Pengukuran di luar taman dilakukan dengan menentukan titik pengukuran yang berjarak kurang lebih 10 meter ke arah luar dari taman. Titik pengukuran adalah lokasi yang mudah dijangkau dan disesuaikan dengan kondisi eksisting pada tapak.

b. Pengukuran Tingkat Kebisingan

Sama seperti pengukuran iklim mikro, pengukuran tingkat kebisingan juga dilakukan di dalam dan di luar taman kota. Hal ini dilakukan untuk mengetahui efektifitas tanaman dalam mengurangi kebisingan dari luar. Cara pengukuran kébisingan dengan mencatat nilai bising maksimum setiap 20 detik sekali selama satu menit hingga mendapatkan nilai bising rata-rata. Titik pengukuran berjarak 10 meter dari batas tepi taman ke arah dalam taman dan ke arah luar taman. Titik pengukuran ditentukan berdasarkan jarak terdekat dari sumber kebisingan, seperti 


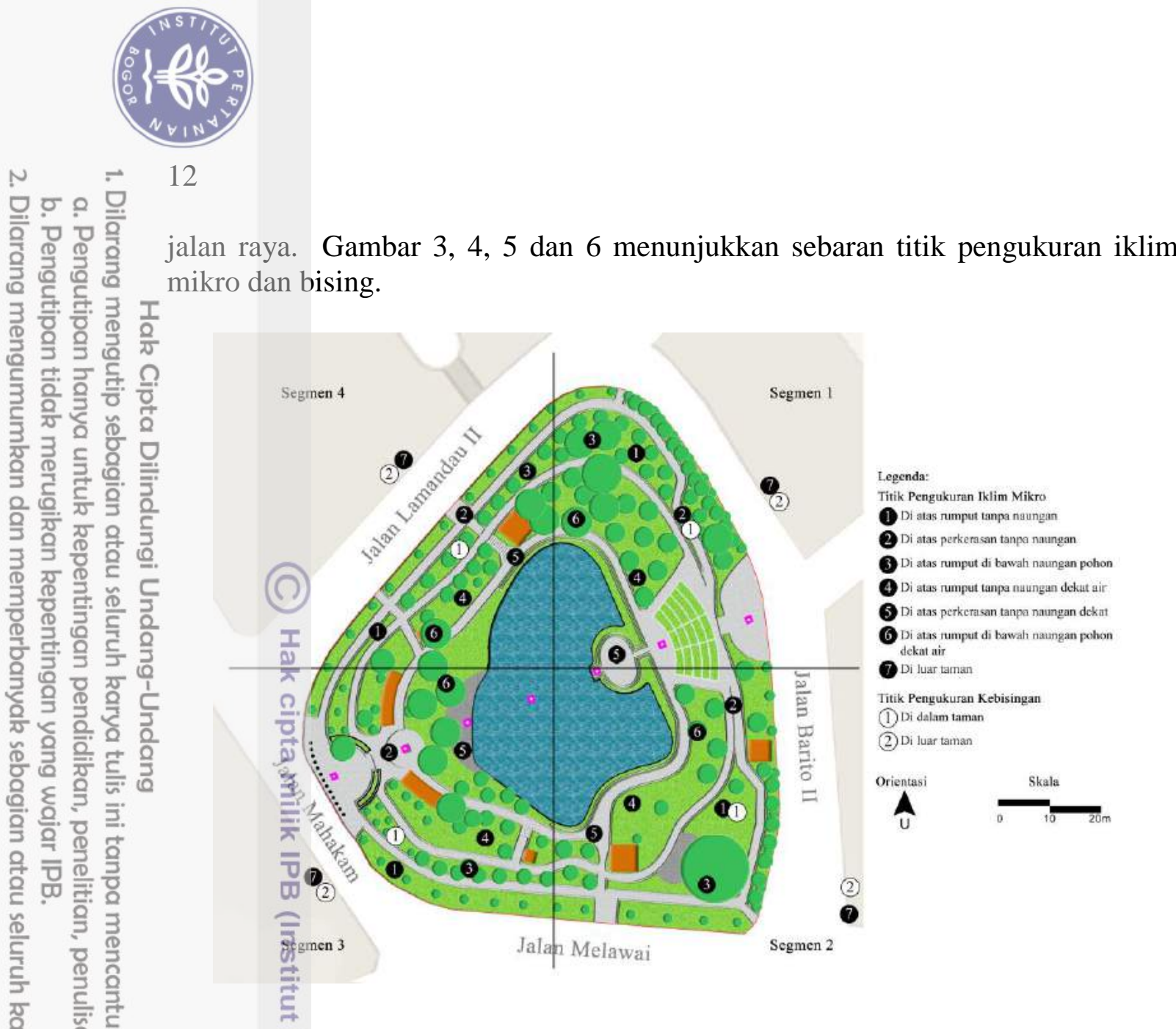

Gambaro3 Penentuan titik pengukuran iklim mikro dan bising Taman Ayodya

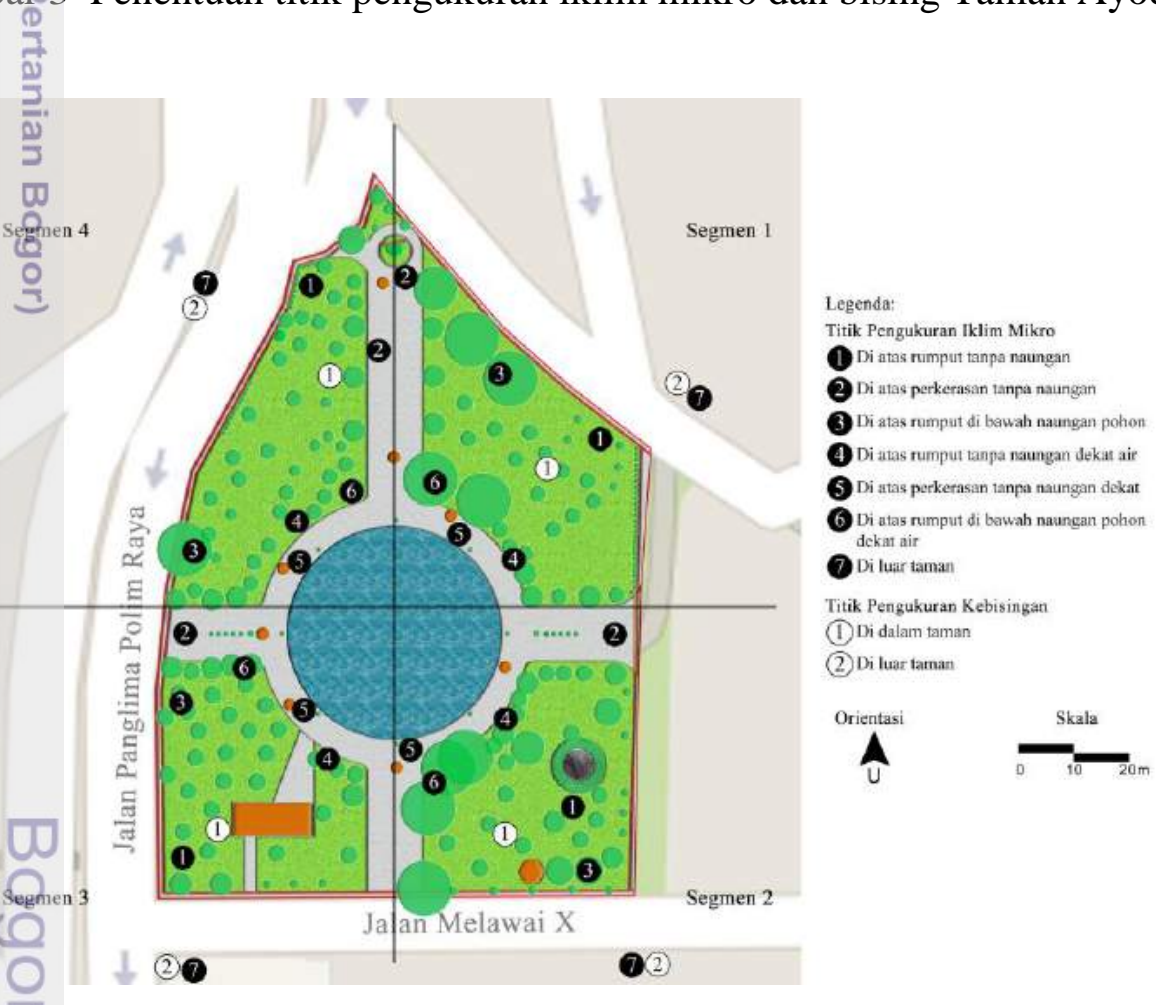

Gambar 4 Penentuan titik pengukuran iklim mikro dan bising Taman Martha Tiahahu 


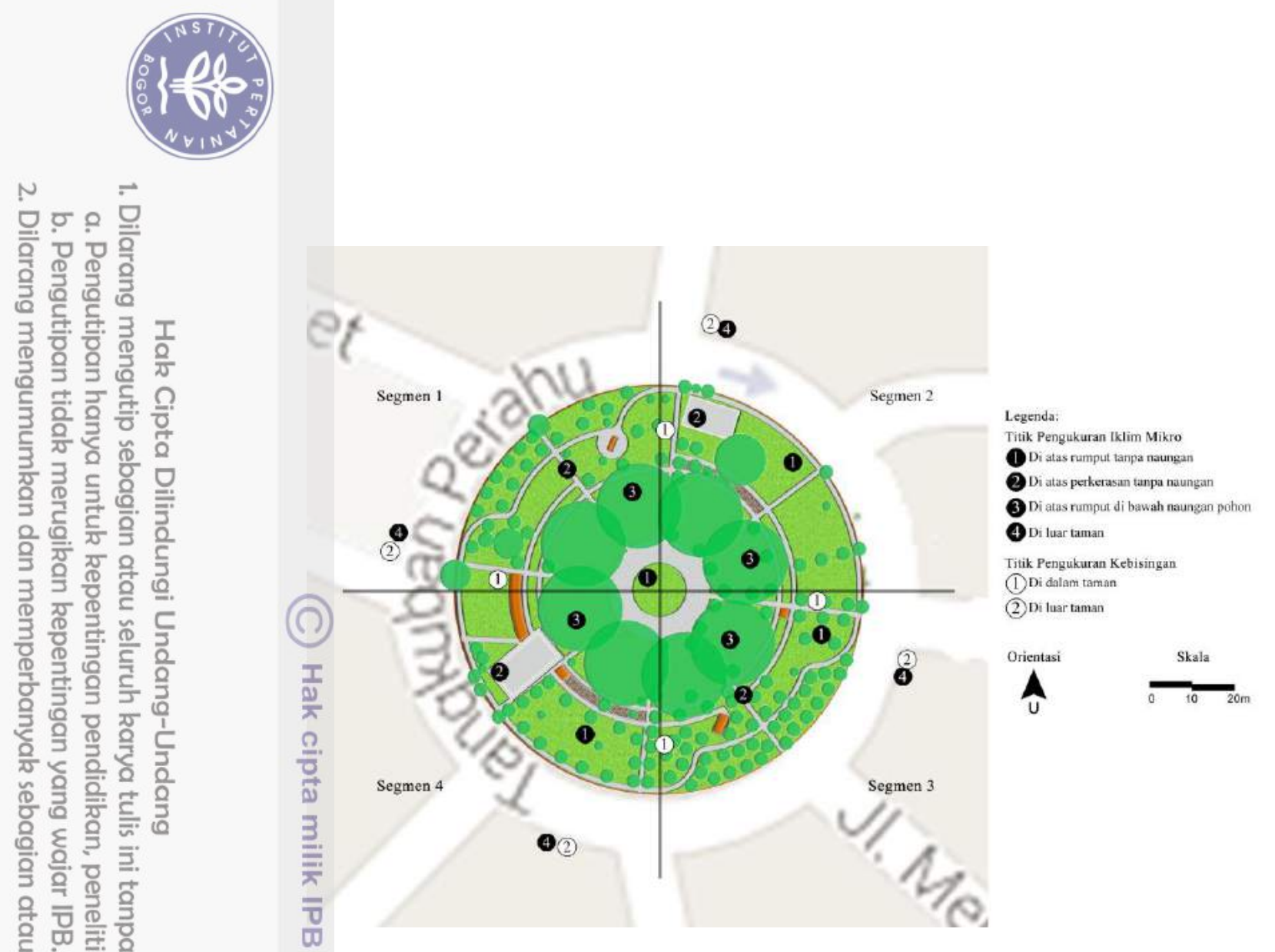

Gamळar 5 Penentuan titik pengukuran iklim mikro dan bising Taman

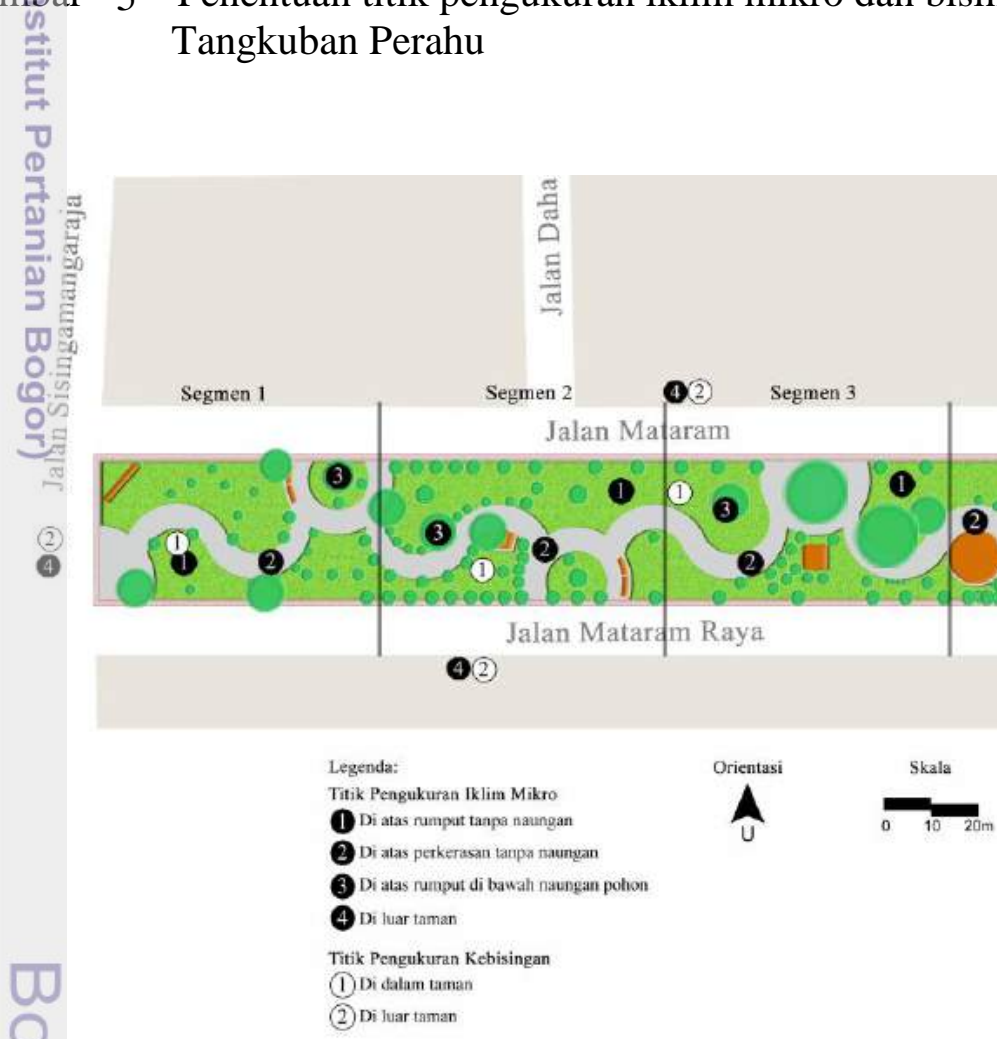

Gambar 6 Penentuan titik pengukuran iklim mikro dan bising Taman Mataram 


\section{c Pemotretan Foto Lanskap}

Objek pengambilan foto ditentukan berdasarkan fungsi area pada taman 증 yang dibagi sesuai dengan kondisi eksisting tapak, seperti gerbang utama dan signage, jalan setapak, kolam, lapangan olahraga, dan area bermain. Titik - pemotretan yang dilakukan adalah dengan sudut pandang sejajar dan posisi setinggi mata. Pemotretan dilakukan dengan menggunakan kamera digital. Gambar diambil dengan titik fokus tertinggi dan diusahakan tidak terhalang oleh bangunan atau tanaman lain.

으. d Persepsi dan Preferensi Masyarakat

Pengambilan data sosial berupa persepsi dan preferensi pengunjung dilakukan dengan pembagian kuesioner kepada pengunjung taman. Waktu pengambitan kuesioner kepada responden bersamaan dengan pengambilan data iklim mikro dan kebisingan yaitu pagi, siang dan sore hari. Pertanyaan yang diberikan terkait karakteristik pengunjung, tujuan, pendapat dan keinginan pengunjūie mengenai taman. Jumlah responden untuk setiap taman 30 responden sehingga total responden dari empat taman yang diteliti yaitu 120 responden.

\subsubsection{Evaluasi}

A $\overline{\bar{n}}$ alisis data dilakukan secara deskriptif dan analisis kualitatif. Pada tahap ini akan dilakukan identifikasi jenis vegetasi beserta fungsinya. Hasil inventarisasi dianalisis dengan literatur. Sedangkan kualitas estetika dianalisis menggunakan data kuesionerterhadap responden.

a Evaluași fungsi ekologis

Dasar penilaian untuk aspek fungsi ekologis disesuaikan dengan kriteria fungsi tapaman lanskap berdasarkan literatur (Tabel 3) (Mahardi 2013). Variabel penilaianountuk fungsi ekologis pohon terdiri atas fungsi peredam kebisingan, modifikasi suhu (peneduh), kontrol kelembaban udara, dan penahan angin. Teknik penilaian fungsi ekologis menggunakan rumus Key Performance Index (KPI) untuk memberi nilai pada masing-masing kriteria (Hidayat 2008). Nilai tertinggi yang diberikan adalah 4 dan yang terendah adalah 1 . Penilaian berdasarkan perbandingan antar spesies pohon dalam taman yang diteliti. Hasil penilaian dibedakan menjadi kategori sangat baik, baik, sedang, dan buruk, serta dihitung persentasenya terhadap total jenis dan total individu tanaman.

Tabel 3 Kriteria penilaian fungsi ekologis

\begin{tabular}{|c|c|}
\hline Variabel & Kriteria Penilaian \\
\hline Peredam bising & 1. Tajuk rapat dan massa daun rapat (DPU Dirjen Bina Marga 1996) \\
\hline & 2. Berdaun tebal (Grey dan Deneke 1978) \\
\hline & 3. Struktur cabang dan batang besar (Grey dan Deneke 1978) \\
\hline & 4. Berdaun jarum (Grey dan Deneke 1978) \\
\hline Modifikasi suhu & 1. Ketinggian kanopi lebih dari 2 m (Simonds 1983) \\
\hline (peneduh) & $\begin{array}{l}\text { 2. Bentuk tajuk spreading, bulat, dome, irregular (DPU Dirjen Bina } \\
\text { Marga 1996) }\end{array}$ \\
\hline 10 & 3. Massa daun padat (DPU Dirjen Bina Marga 1996) \\
\hline
\end{tabular}


Tabel 3 Kriteria penilaian fungsi ekologis (lanjutan)

\begin{tabular}{|c|c|}
\hline Variabel & Kriteria Penilaian \\
\hline $\begin{array}{l}\text { Modifikasi suhu } \\
\text { (peneduh) }\end{array}$ & 4. Daun tebal (Carpenter et al. 1975) \\
\hline \multirow{4}{*}{$\begin{array}{l}\text { Kontrol kelembaban } \\
\text { udara }\end{array}$} & 1. Kerapatan daun rendah (Bianpoen et al. 1989) \\
\hline & 2. Berdaun jarum atau kasar (Grey dan Deneke 1978) \\
\hline & 3. Tekstur batang kasar (Grey dan Deneke 1978) \\
\hline & 4. Jumlah daun banyak (Carpenter et al. 1975) \\
\hline \multirow{4}{*}{ Penahan angin } & 1. Tanaman tinggi (Carpenter et al. 1975$)$ \\
\hline & 2. Daunnya tidak mudah gugur (Dahlan 1992) \\
\hline & 3. Massa daun rapat (DPU Dirjen Bina Marga 1996) \\
\hline & 4. Berdaun tebal (DPU Dirjen Bina Marga 1996) \\
\hline
\end{tabular}

Penilaian

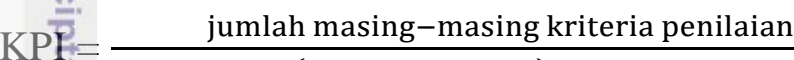

= $\overline{\text { jumlah ideal (total maksimum)masing-masing kriteria }}$

Kategori

Nilą 1: Buruk, bila $\leq 40 \%$ kriteria terpenuhi

Nilai 2: Sedang, bila 41-60\% kriteria terpenuhi

Nifi 3: Baik, bila 61-80\% kriteria terpenuhi

Nilai 4: Sangat baik, bila $\geq 81 \%$ kriteria terpenuhi

(Hiđayat, 2008)

Persentase terhadap total jenis $=\frac{\text { jumlah jenis tanaman kategori }}{\text { total jenis tanaman }} \times 100 \%$

Perš̉ntase terhadap total individu $=\frac{\text { jumlah individu tanaman kategori }}{\text { total individu tanaman }} \times 100 \%$ 00

Skor per taman

(Pessentase terhadap total individu kategori Buruk x 1) + (Persentase terhadap total individu kategori Sedang x 2) + (Persentase terhadap total individu kategori Baik x 3) + (Persentase terhadap total individu kategori Sangat baik x 4).

Selanjutnya hasil penilaian dibandingkan dengan pengukuran iklim mikro yang meliputi suhu udara, kelembaban udara, dan tingkat kebisingan dianalisis dengan membandingkan kondisi iklim mikro pada tapak dengan kondisi kenyamanan ideal. Indeks kenyamanan iklim mikro dihitung menggunakan rumus Thermal Humidity Index (THI). Berdasarkan Laurie (1986), manusia di daerah tropis akan merasa relatif nyaman jika berada pada suhu udara sekitar $27-28^{\circ} \mathrm{C}$. Sedangkan tingkat kebisingan dibandingkan dengan standar baku mutu kebisingan (Tabel 4). Formulasi THI adalah sebagai berikut.

Keterangan:

$\mathrm{THI}=0,8 \mathrm{~T}+(\mathrm{RH} \times \mathrm{T}) / 500$

$\mathrm{THI}=$ Thermal Humidity Index

$\mathrm{T}=$ Suhu udara $\left({ }^{\circ} \mathrm{C}\right)$

RH $=$ Kelembaban udara $(\%)$ 
Tabel 4 Baku mutu tingkat kebisingan

\begin{tabular}{|c|c|c|}
\hline No & Peruntukan Kawasan/Lingkungan Kegiatan & Tingkat Kebisingan (dBA) \\
\hline \multirow[t]{13}{*}{ A } & Peruntukan Kawasan: & \\
\hline & 1. Perumahan dan Permukiman & 55 \\
\hline & 2. Perdagangan dan Jasa & 70 \\
\hline & 3. Perkantoran dan Perdagangan & 65 \\
\hline & 4. Ruang Terbuka Hijau & 50 \\
\hline & 5. Industri & 70 \\
\hline & 6. Pemerintahan dan Fasilitas Umum & 60 \\
\hline & 7. Rekreasi & 70 \\
\hline & 8. Khusus: & \\
\hline & Bandar Udara *) & \\
\hline & IStasiun Kereta Api & 60 \\
\hline & Pelabuhan Laut & 70 \\
\hline & Cagar Budaya *) & \\
\hline \multirow[t]{4}{*}{$\mathrm{B}$} & Lingkungan Kegiatan: & \\
\hline & 1. Rumah Sakit atau sejenisnya & 55 \\
\hline & 2. Sekolah atau sejenisnya & 55 \\
\hline & 3. Témpat Ibadah atau sejenisnya & 55 \\
\hline
\end{tabular}

Ket: *) disesuaikan dengan Ketentuan Menteri Perhubungan.

Sumber: KepMNLH No. KEP-48/MENLH/11/1996

b Evaluasi kualitas estetika

Pênilaian dan evaluasi untuk kualitas estetika dilakukan dengan menerapkan metode Scenic Beauty Estimation (SBE) yang diperkenalkan oleh Daniel dā Boster (1976). Penerapan metode SBE terdiri dari tiga langkah utama, yaitu: (1) pengambilan foto lanskap, (2) presentasi slide foto, dan (3) analisis data.

Responden yang dituju adalah orang yang sudah mendapatkan pemahaman lebih jath tentang ilmu arsitektur lanskap, yaitu mahasiswa Departemen Arsitekturo Lanskap IPB semester 4 dan 8 sebanyak 30 mahasiswa yang telah mengambil MK. Teori Desain Lanskap. Harapannya responden dapat menilai secara objektif terkait kualitas estetika yang akan dievaluasi. Hasil penilaian responden selanjutnya diolah secara statistik dengan perhitungan SBE berdasarkan skala penilaian $1-10$.

Penilaian yang dilakukan oleh responden kemudian akan diubah menjadi sebuah nilai dengan menggunakan formulasi sebagai berikut:

$$
Z_{i j}=\frac{R_{i j}-\bar{R}_{j}}{S_{j}}
$$

Keterangan:

$\mathrm{Zij}=$ Standar penilaian untuk nilai respon ke i oleh responden $\mathrm{j}$

$\overline{\mathrm{R}} \mathrm{j}=$ nilai rata-rata dari semua nilai oleh responden $\mathrm{j}$

Rij = nitai $\mathrm{i}$ dari responden $\mathrm{j}$

$\mathrm{S}_{\mathrm{j}} \quad=$ standar deviasi dari seluruh nilai oleh responden $\mathrm{j}$

Kemudian dilakukan tahap analisis terhadap data yang diperoleh dari tahap presentasi slide. Analisa data ditujukan untuk mendapatkan nilai SBE yaitu indeks kuantitas pendugaan keindahan suatu lanskap (Daniel dan Boster 1976). Tiap peringkat nilai akan dihitung frekuensi kumulatif, peluang kumulatif, nilai Z, dan nilai $Z$ rata - rata. Kemudian ditentukan satu nilai $\mathrm{Z}$ dari foto lanskap tertentu 
sebagai standar (nilai Z yang paling mendekati nol). Nilai SBE diformulasikan sebagai berikut:

SBEx $=(Z L x-$ ZLs $) \times 100$

Keterangan:

SBEx = Nilai SE lanskap ke $\mathrm{x}$

ZLx = Nilai rata-rata Z lanskap ke $\mathrm{x}$

ZLs = Nilai rata-rata Z lanskap standar

Bereasarkan nilai SBE yang diperoleh, setiap objek dikelompokkan menjadi kualitas estetika rendah, kualitas estetika sedang, dan kualitas estetika tinggi. Pengelompokkan ini dilakukan dengan menggunakan standar oleh Daniel dan Boster (1976), yaitu kualitas estetika rendah memiliki nilai SBE $<-20$, kualitas estetika sedang apabila memiliki nilai SBE antara -20 sampai 20, dan kualitas estetika tinggi apabila nilai SBE $>20$.

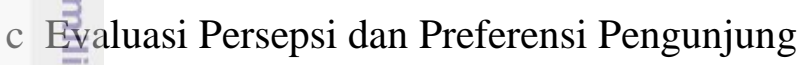

Berdasarkan penyebaran kuesioner, dapat diketahui karakteristik engunjung, tujuan, serta keinginan pengunjung pada tapak. Data persepsi dan preferensi pengunjung diolah menggunakan metode statistika deskriptif. Hasil pengolahan data dibuat menjadi bagan atau diagram untuk penjelasan yang lebih mudah.

\subsubsection{Rekomendasi}

Pada tahap ini dirumuskan rekomendasi untuk penerapan tata hijau di taman kota terkait aspek fungsi ekologis dan estetika. Rekomendasi ini dirumuskan sebagai acuan bagi pemerintah daerah dalam pengembangan taman kotas selanjutnya.

\subsection{Batasan Penelitian}

Kegiatan penelitian yang dilakukan di empat lokasi di Jakarta Selatan sebatas mengevaluasi pengaruh vegetasi terhadap iklim mikro dan bising dengan membandingkan data hasil pengukuran lapang secara berkala. Unsur iklim mikro yang diukur pun hanya 2 unsur yang telah disebutkan pada kerangka pikir sebelumnya yaitu suhu udara dan kelembaban udara. Selain itu, dilakukan evaluasi estetika taman dengan penilaian SBE dan karakteristik pengunjung taman dengan penyebaran kuesioner. Hasil akhir dari penelitian ini dirangkum secara spasial dan deskriptif. 


\section{KONDISI UMUM}

\subsection{Letak, Luas, dan Batas Lokasi}

Penelitian dilaksanakan di empat taman di Jakarta Selatan, yaitu Taman Ayodya, Taman Martha Tiahahu, Taman Tangkuban Perahu, dan Taman Mataram. Secara Administratif, Taman Ayodya terletak di Jalan Barito, Kel. Kramat Pela, Kec. Kebayoran Baru dan secara geografis terletak pada 6 ${ }^{\circ} 14^{\prime} 43^{\prime \prime}$ LS $106^{\circ} 47^{\prime} 40^{\prime \prime}$ BT. Taman yang memiliki luas $8307 \mathrm{~m}^{2}$ memiliki akses terbuka dari wilayah sekitar dan batas taman berupa semak rendah. Batasan tapak Taman Ayodya yaitu Jalan Lamandau II di sebelah utara, Jalan Mahakam di sebelah timur, Jalän Melawai di sebelah selatan dan Jalan Barito II di sebelah barat.

Taman Martha Tiahahu terletak di Jalan Sisingamangaraja, Kel. Melawai, Kec. Kebâyoran Baru dan secara geografis terletak pada 6 ${ }^{\circ} 14^{\prime} 36^{\prime \prime}$ LS $106^{\circ} 47^{\prime} 55^{\prime \prime}$ BT. Luasitaman sebesar $9402 \mathrm{~m}^{2}$ memiliki batas yang jelas dengan wilayah di sekitarnyā yaitu pagar besi. Batasan tapak Taman Martha Tiahahu yaitu Jalan Sunan Kälijaga di sebelah utara, mall Blok M Square di sebelah timur, Jalan Melawai X di sebelah selatan dan Jalan Panglima Polim Raya di sebelah barat.

Tanan Tangkuban Perahu terletak di Jalan Tangkuban Perahu, Kel. Guntur, Kec. Setia Budi dan secara geografis terletak pada 6 $12^{\circ} 27^{\prime \prime}$ LS $106^{\circ} 50$ '07” BT. Luas tanfan sebesar $7481 \mathrm{~m}^{2}$ memiliki batas yang jelas dengan wilayah di sekitarnyâ yaitu pagar besi. Batasan tapak Taman Tangkuban Perahu yaitu Jalan Gede di sebelah utara, Jalan Merbabu di sebelah timur, Jalan Muria di sebelah selatan dan Jalan Prahu di sebelah barat.

Tamäan Mataram terletak di Jalan Mataram Raya, Kel. Selong, Kec. Kebayoran Baru dan secara geografis terletak pada 6 13 '58” LS $106^{\circ} 47^{\prime} 58^{\prime \prime}$ BT. Luas taman sebesar $8058 \mathrm{~m}^{2}$ memiliki akses terbuka dari wilayah sekitar dan batas taman berupa semak rendah. Batasan tapak Taman Mataram yaitu Jalan Mataram de sebelah utara, Jalan Pattimura di sebelah timur, Jalan Mataram Raya di sebelah selatan dan Jalan Sisingamangaraja di sebelah barat.

\subsection{Keadaan Fisik Taman Ayodya, Taman Martha Tiahahu, Taman Tangkuban Perahu, dan Taman Mataram}

Kawasan yang saat ini bernama Taman Ayodya awalnya merupakan taman dengan danau kecil di tengahnya dan telah ada sejak tahun 1950-an (Gambar 7a). Tahun 1970-an hingga 1980-an taman ini beralih fungsi menjadi area penjualan bunga dan penjualan ikan hias yang dikenal sebagai Pasar Barito. Kemudian pada tahun 2007 Pemerintah Provinsi (Pemprov) DKI Jakarta berusaha mengembalikan fungsi ruang terbuka hijau taman dari Pasar Barito. Dalam usaha mengembalikan fungsi ruang terbuka hijau tersebut, Pemprov melalui Dinas Pertamanan dan Pemakaman DKI Jakarta melakukan sayembara desain taman. Tepat tanggal 15 Maret 2009 lahirlah sebuah taman yang diberi nama Taman Ayodya yang diresmikan oleh Gubernur Jakarta, Fauzi Bowo (Gambar 7b). 


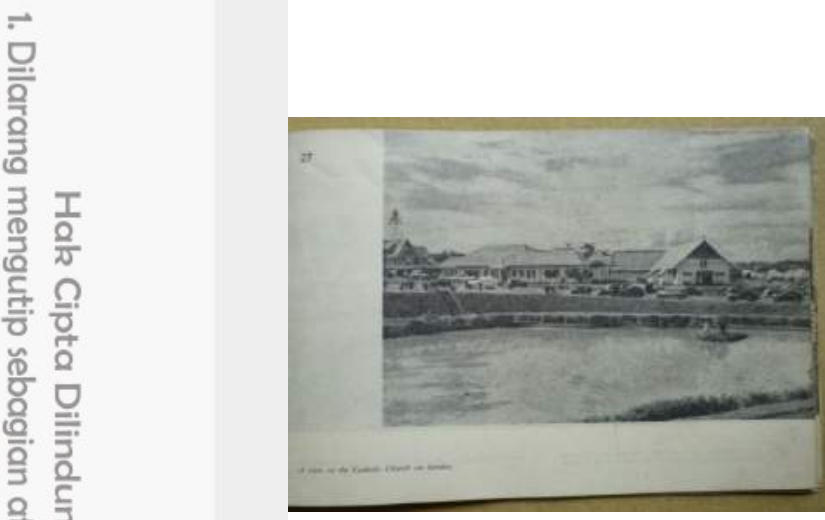

(a)

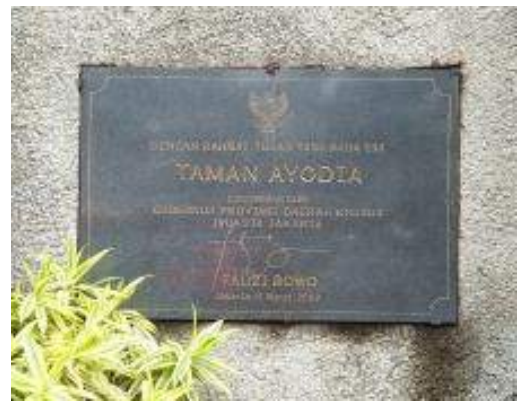

(b)

Sumber: (a) Buku Kebajoran, a new town under construction $\begin{array}{cc}\text { Gambar } & \text { (a) Lanskap Taman Ayodya tahun 1950, (b) Peresmian Taman Ayodya } \\ & \text { tahun } 2009\end{array}$

Taman Ayodya memiliki fasilitas seperti sarana olahraga (outdoor gym), perpustakaan apung, amfiteater, jogging track, gazebo dan kursi taman (Gambar 8). Fasilitas Taman Ayodya sudah lebih termanfaatkan dibanding ketiga taman lain, terlihat dengan lebih banyak aktivitas yang dilakukan pengguna taman seperti jogging, berlatih olahraga di gym outdoor dan duduk-duduk. Segi penfeliharaan taman ini juga cukup baik, kondisi taman dan kolamnya terawat dan bersih dari sampah.

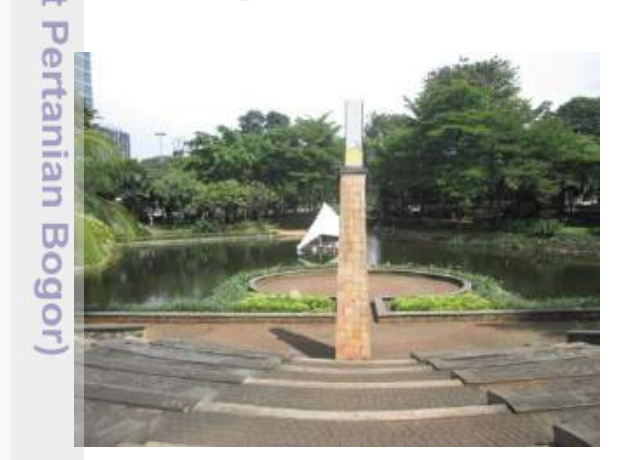

(a)

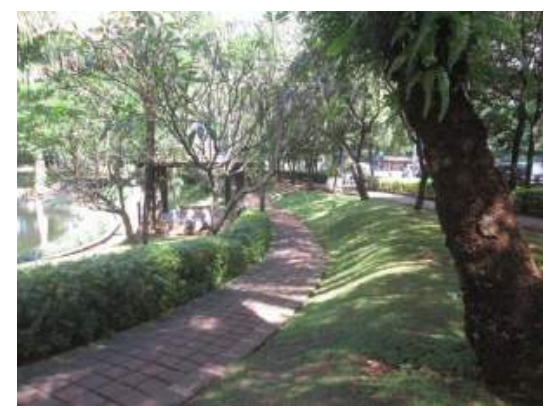

(b)

Gambar 8 Kondisi eksisting Taman Ayodya: (a) amfiteater mengarah ke danau dan (b) jogging track

Tidak jauh dari Taman Ayodya, terdapat sebuah taman yang namanya diambil dari salah satu nama pahlawan perempuan Indonesia, Christina Martha Tiahahu. Taman Martha Tiahahu merupakan taman yang berada di tengah kota karena letaknya yang tidak jauh dari pusat perbelanjaan dan terminal Blok M, Kebayoran Baru. Taman yang dirancang oleh M. Soesilo sejak tahun 1948 ini adalah salah satu taman milik Pemerintah Provinsi DKI Jakarta yang dikelola setiap harinya oleh pihak swasta (PT. Langgeng Ayomlestari). Focal Point taman ini jalah sebuah kolam air mancur yang dapat dinikmati pengunjung taman (Gambar 9a). Fasilitas yang terdapat dalam taman seperti bangku taman dan patung-patung binatang sebagai penghias taman yang dapat dijadikan objek foto 
pengunjung (Gambar 9b). Taman yang banyak digunakan sebagai tempat melepas penat ini awalnya terbuka untuk umum, namun dengan alasan keamanan akhirnya I diberlakukan jam buka taman mulai pukul 09.00 hingga pukul 17.00 WIB. Meski pengelolaan taman ini dikelola oleh swasta, fasilitas yang ada di taman banyak yang perlu diperbaiki.

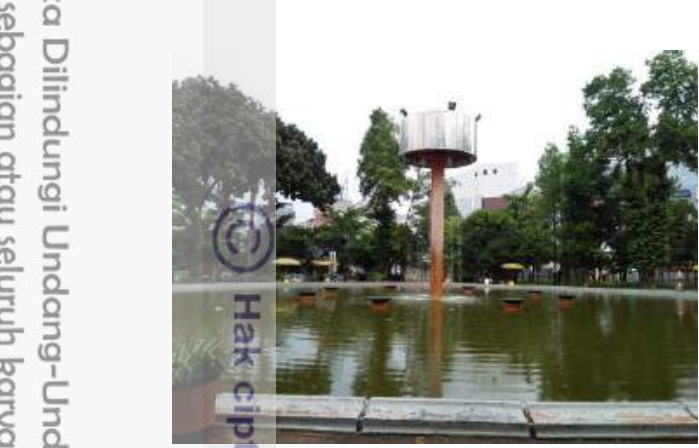

(a)

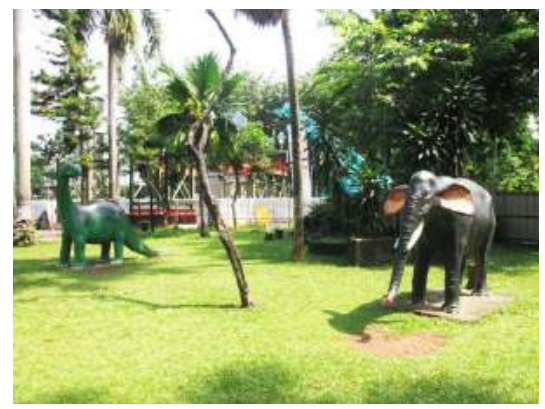

(b)

Gambar $\overline{\bar{F}}$ Kondisi eksisting Taman Martha Tiahahu: (a) kolam air mancur, (b) patung-patung binatang

Tanḡ $\overline{\overline{\bar{a}}}$ Tangkuban Perahu merupakan salah satu taman di DKI Jakarta yang bagi sebagian orang masih mengira taman ini terletak di Jawa Barat. Penamaan Tangkuban Perahu dikarenakan letak taman yang berada di Jalan Tangkuban Perahu. Tetak taman yang berada disekitar kawasan perumahan, pedidikan dan perkantorān ini cukup aktif penggunaannya karena siapapun mudah untuk berkunjung ke taman. Penggunaan taman ini aktif setiap hari terutama saat siang. Taman mïlai sepi saat petang karena didalam taman tidak banyak tersedia lampu serta rapatnya tajuk pohon membuat cahaya dari jalan terhalang masuk kedalam taman. Fasilitas yang tersedia ditaman ini cukup lengkap, diantaranya ada fasilitas olahraga flapangan basket dan futsal), jogging track, area bermain anak, jalur refleksi, dll (Gambar 10).

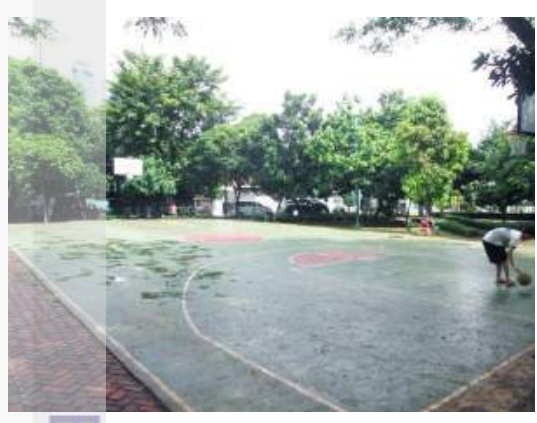

(a)

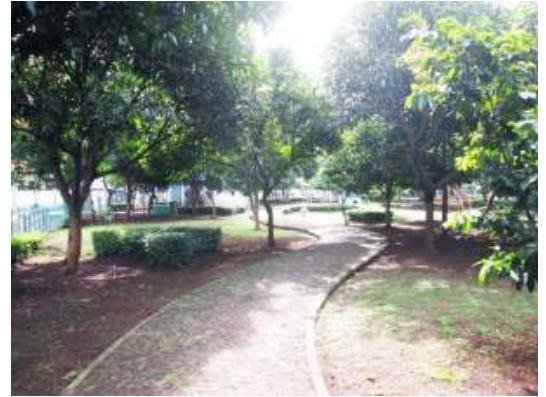

(b)

Gambar 10 Kondisi eksisting Taman Tangkuban Perahu: (a) lapangan basket dan (b) jogging track 
Berbeda dengan ketiga taman sebelumnya, Taman Mataram dahulunya adalah sebuah SPBU (Stasiun Pengisian Bahan Bakar Umum). Sesuai peruntukannya, lahan SPBU tersebut berada di jalur hijau yang harus direfungsi. Upaya Pemprov DKI Jakarta untuk melakukan refungsi dapat terlaksana pada tahun 2009 dengan terbitnya Surat Keputusan (SK) Gubernur DKI Jakarta No. 728/2009 Tanggal 7 Mei 2009 Tentang Penertiban 27 (Dua Puluh Tujuh) Titik Lokasi Stasiun pengisian Bahan Bakar Umum (SPBU) yang beroperasi di Jalur Hijau/Taman/Ruang Terbuka Hijau dan Daerah Milik Jalan. Pembangunan Taman Mataram dilaksanakan secara bertahap mulai tahun 2011 selama dua tahun. Fasilitas yang ada di Taman Mataram diantaranya bangku taman, area bermain anak, shelter dan jogging track (Gambar 11). Beberapa pohon pelindung dan tanaman hias juga sudah banyak di taman yang baru berusia 3 tahun ini.

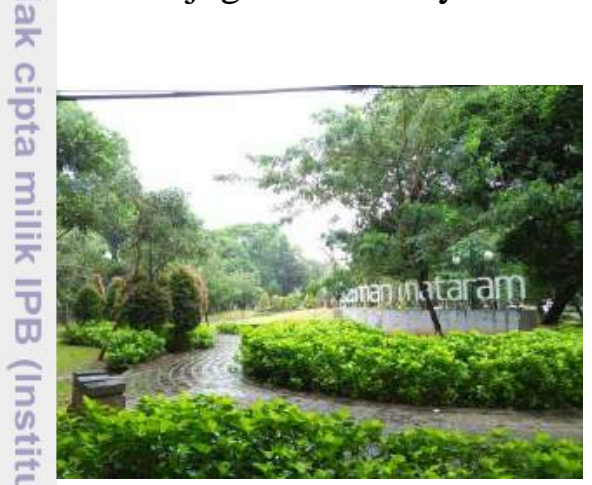

(a)

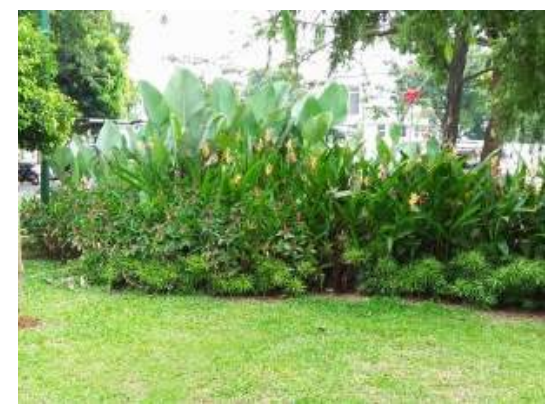

(b)

Ganear 11 Kondisi eksisting Taman Mataram: (a) welcome area dan (b) tanaman hias

\section{HASIL DAN PEMBAHASAN}

\subsection{Identifikasi Jenis dan Fungsi Tanaman}

Identifikasi jenis dan fungsi tanaman yang ada di empat taman yang diteliti. Hasil identifikasi jenis dan fungsi tanaman ialah adanya perbedaan tipe vegetasi. Tipe vegetasi yang berbeda-beda dapat mempengaruhi kondisi taman secara ekologis maupun estetika.

\subsubsection{Taman Ayodya}

Tipe vegetasi yang ada di Taman Ayodya diantaranya pohon peneduh, pohon pengarah dan tanaman display (estetika) berupa semak dan tanaman penutup tanah serta rumput. Vegetasi di Taman Ayodya terdiri atas 18 spesies dan $17 Z$ individu pohon (Tabel 5). Tanaman yang paling banyak ditemukan di Taman Ayedya adalah Sikat botol (Callistemon citrinus) yang berfungsi sebagai pengarah. Ketapang daun kecil (Bucida molineti) dan Beringin (Ficus benjamina) berfungsi sebagai peneduh. Cemara norflok (Araucaria heterophylla), Bismarck palm (Bismarckia nobilis), dan Canary island date palm (Phoenix canariensis) berfungsi sebagai focal point. Pola penanaman di Taman Ayodya bervariasi, ada 
tanaman sejenis yang ditanam berkelompok, tanaman berkelompok campuran, dan tanaman soliter. Kondisi tanaman di taman ini cukup baik karena I pemeliharaan yang intensif.

Tabel 5 Jenis dan fungsi pohon pada Taman Ayodya

\begin{tabular}{|c|c|c|c|c|}
\hline No & Nama Ilmiah & Nama Lokal & Jumlah & Fungsi \\
\hline 1 & Agathis dammara & Damar & 3 & screen \\
\hline 2 & Araucaria heterophylla & Cemara norflok & 7 & estetika \\
\hline 3 & Bismarckia nobilis & Bismarck palm & 3 & estetika \\
\hline 4 & Borassus flabellifer & Lontar & 16 & barrier \\
\hline 5 & Bucida molineti & Ketapang daun kecil & 9 & peneduh \\
\hline 6 & Cattistemon citrinus & Sikat botol & 54 & pengarah, barrier \\
\hline 7 & $\begin{array}{l}\text { Chity sallidocarpus } \\
\text { lucubensis }\end{array}$ & Palem kuning & 7 & estetika \\
\hline 8 & Cō̄os nucifera & Kelapa & 19 & estetika \\
\hline 9 & Cyrtostachis renda & Palem merah & 2 & estetika \\
\hline 10 & Ficus benjamina & Beringin & 1 & peneduh \\
\hline 11 & Mi & Tanjung & 28 & barrier \\
\hline 12 & Phōenix canariensis & Canary island date palm & 5 & estetika \\
\hline 13 & Plūeria rubra & Kamboja & 7 & estetika \\
\hline 14 & Potyalthia longifolia & Glodogan tiang & 11 & pengarah, screen \\
\hline 15 & Pterocarpus indicus & Angsana & 2 & peneduh \\
\hline 16 & Samanea saman & Trembesi & 1 & pengarah, screen \\
\hline 17 & Tabébuia chrysanta & Tabebuya & 2 & pengarah \\
\hline 18 & Terminalia catappa & Ketapang & 1 & peneduh, estetika \\
\hline
\end{tabular}

\subsubsection{Taman Martha Tiahahu}

Tịpe vegetasi yang ada di Taman Martha Tiahahu diantaranya pohon peneduh, pohon pengarah dan tanaman display (estetika) berupa semak dan rumput. Wegetasi di Taman Martha Tiahahu terdiri atas 16 spesies dan jumlah 162 individu pohon (Tabel 6). Tanaman yang paling banyak ditemukan di Taman Martha Tiahahu adalah Pinus (Pinus merkusii) yang berfungsi sebagai pengontrol bising. Tanaman peneduh diantaranya Sawo kecik (Manilkara kauki), Bungur (Lagerstromia speciosa) dan Ketapang (Terminalia catappa). Pola penanaman di Taman Martha Tiahahu bervariasi, ada tanaman sejenis yang ditanam berkelompok dan tanaman berkelompok campuran. Kondisi tanaman di taman ini cukup baik karena pemeliharaan yang intensif, namun terdapat beberapa tanaman semak yang tidak dipangkas.

Tabel 6 Jenis dan fungsi pohon pada Taman Martha Tiahahu

\begin{tabular}{rllrl}
\hline No & \multicolumn{1}{c}{ Nama Ilmiah } & \multicolumn{1}{c}{ Nama Lokal } & Jumlah & Fungsi \\
\hline 1 & Averrhoa carambola & Belimbing & 2 & peneduh \\
2 & Bismarckia nobilis & Bismarck palm & 7 & estetika \\
3 & Chrysalidocarpus & Palem kuning & 11 & estetika \\
& lutescens & Biola cantik & 3 & peneduh \\
4 & Ficus lyrata & 1 & peneduh \\
5 & Lagerstromia speciosa & Bungur & 6 & peneduh \\
6 & Mangifera indica & Mangga & Sawn kecik & peneduh \\
7 & Manilkara kauki & Sawo & & \\
\hline
\end{tabular}


Tabel 6 Jenis dan fungsi pohon pada Taman Martha Tiahahu (lanjutan)

\begin{tabular}{rllrl}
\hline No & \multicolumn{1}{c}{ Nama Ilmiah } & \multicolumn{1}{c}{ Nama Lokal } & Jumlah & \multicolumn{1}{c}{ Fungsi } \\
\hline 8 & Mascarena lagenicaulis & Palem botol & 2 & estetika \\
9 & Pinus merkusii & Pinus & 49 & peneduh \\
10 & Polyalthia fragrans & Glodogan bulat & 6 & screen, estetika \\
11 & Pterocarpus indicus & Angsana & 4 & peneduh \\
12 & Roystonea regia & Palem raja & 21 & pengarah \\
13 & Sweitenia mahogani & Mahoni & 5 & peneduh \\
14 & Terminalia catappa & Ketapang & 1 & peneduh \\
15 & Veitchia merilii & Palem putri & 20 & pengarah \\
16 & Wodyetia bifurcata & Palem ekor tupai & 2 & pengarah \\
\hline
\end{tabular}

\section{1 $\frac{\overline{3}}{2}$ Taman Tangkuban Perahu}

Tipe vegetasi yang ada di Taman Tangkuban Perahu diantaranya pohon penèduh, pohon pengarah, pengontrol bising dan tanaman display (estetika) berupa semak dan tanaman penutup tanah. Vegetasi di Taman Tangkuban Perahu terdiri atas 13 spesies dan jumlah 159 individu pohon (Tabel 7). Tanaman yang palīg banyak ditemukan di Taman Tangkuban Perahu adalah Mangga (Māngifera indica) yang berfungsi sebagai peneduh. Tanaman pengarahnya seperti Tabebuya (Tabebuia chrysanta). Pola penanaman di Taman Tangkuban Perăhu bervariasi, ada tanaman sejenis yang ditanam berkelompok, tanaman berkelompok campuran. Kondisi tanaman di taman ini cukup baik karena penteliharaan yang intensif, namun terdapat beberapa tanaman pembatas jalan yang tidak terawat dan rumput yang tidak tumbuh maksimal karena tajuk pohon terlalu rapat.

Tabel 7 Jenis dan fungsi pohon pada Taman Tangkuban Perahu

\begin{tabular}{|c|c|c|c|c|}
\hline $\mathrm{Ng}$ & Nama Ilmiah & Nama Lokal & Jumlah & Fungsi \\
\hline$\frac{0}{d}$ & Araucaria heterophylla & Cemara norflok & 2 & estetika \\
\hline 3 & Artocarpus communis & Sukun & 1 & peneduh \\
\hline 3 & Artocarpus heterophyllus & Nangka & 1 & peneduh \\
\hline 4 & Butia capitata & Jelly palm & 1 & estetika \\
\hline 5 & Mangifera indica & Mangga & 127 & peneduh \\
\hline 6 & Manglietia glauca & Manglid & 1 & peneduh \\
\hline 7 & Persea americana & Alpukat & 1 & peneduh \\
\hline 8 & Prunus avium & Ceri & 1 & estetika \\
\hline 9 & Pterocarpus indicus & Angsana & 1 & peneduh \\
\hline 10 & Samanea saman & Trembesi & 8 & peneduh \\
\hline 11 & Swietenia mahogani & Mahoni & 6 & peneduh \\
\hline 12 & Tabebuia chrysanta & Tabebuya & 8 & pengarah \\
\hline 13 & Tamarindus indica & Asam jawa & 1 & peneduh \\
\hline
\end{tabular}

\subsubsection{Taman Mataram}

Tipe vegetasi yang ada di Taman Mataram diantaranya pohon pengarah, pohon pengontrol bising, pohon peneduh dan tanaman display (estetika) berupa semak dan tanaman penutup tanah serta rumput. Vegetasi di Taman Mataram terdiri atas 12 spesies dan jumlah 146 individu pohon (Tabel 8). Tanaman yang paling banyak ditemukan di Taman Mataram adalah Canary island date palm 
(Phoenix canariensis) yang berfungsi sebagai pengarah. Tanaman pengarah lainnya seperti Sikat botol (Callistemon citrinus) dan Tabebuya (Tabebuia I chrysanta) yang juga dominan di taman ini. Pola penanaman di Taman Mataram bervariasi, ada tanaman sejenis yang ditanam berkelompok, tanaman berkelompok - campuran. Kondisi tanaman di taman ini cukup baik karena pemeliharaan yang ¿ intensif, namun terdapat beberapa tanaman yang terserang penyakit dan hama seperti ulat.

Tabel 8 Jenis dan fungsi pohon pada Taman Mataram

\begin{tabular}{rllrl}
\hline No & Nama Ilmiah & \multicolumn{1}{c}{ Nama Lokal } & Jumlah & \multicolumn{1}{c}{ Fungsi } \\
\hline 1 & Alstonia scholaris & Pulai & 3 & estetika \\
& Artacarpus heterophyllus & Nangka & 1 & peneduh \\
& Callistemon citrinus & Sikat botol & 26 & pengarah \\
4 & Ficus elastica & Beringin karet & 1 & peneduh \\
5 & Mimusops elengi & Tanjung & 23 & pengarah \\
6 & Phönix canariensis & Canary island date & 40 & barrier \\
& palm & & \\
7 & Potralthia fragrans & Glodogan bulat & 1 & estetika \\
8 & Pterocarpus indicus & Angsana & 2 & peneduh \\
9 & Sarganea saman & Trembesi & 9 & peneduh \\
10 & Sweitenia mahogani & Mahoni & 5 & peneduh \\
11 & TaFebuia chrysanta & Tabebuya & 26 & pengarah, estetika \\
12 & Terminalia catappa & Ketapang & 9 & estetika \\
\hline
\end{tabular}

\subsection{Evaluasi Fungsi Ekologis}

Iklim mikro pada keempat lokasi penelitian relatif sama dengan suhu ratarata antara $30^{\circ} \mathrm{C}$ sampai $34^{\circ} \mathrm{C}$. Kondisi tersebut sejalan dengan iklim Jakarta Selatan berdasarkan data BMKG Stasiun Pondok Betung selama 10 tahun terakhir (Lampiran 4 dan 5). Dengan kondisi tersebut maka yang dapat membedakan nilai kenyamanan setiap taman adalah pengaruh keberadaan vegetasi dalam mengontrol iklim mikro. Robinette (1983) mengemukakan bahwa area yang ternaungi menerima sedikit energi radiasi matahari dibandingkan dengan area yang terbuka sehingga area ternaungi memiliki suhu yang lebih rendah. Tanaman dalam lanskap memiliki fungsi yang dibagi menjadi tiga kategori, yaitu fungsi struktural, fungsi lingkungan, dan fungsi visual (Booth 1983). Fungsi lingkungan dapat juga dikatakan sebagai fungsi ekologis. Penelitian ini menjabarkan fungsi ekologis tanaman menjadi empat, antara lain: 1) peredam bising; 2) modifikasi suhu (peneduh); 3) pengontrol kelembaban udara; dan 4) penahan angin.

\subsubsection{Fungsi peredam bising}

Berdasarkan SK Menteri Negara Lingkungan Hidup No: Kep.Men48/MEN.DH/11/1996, kebisingan adalah bunyi yang tidak diinginkan dari usaha atau kégiatan dalam tingkat dan waktu tertentu yang dapat menimbulkan gangguaßkesehatan manusia dan kenyamanan lingkungan. Tingkat kebisingan yang dianjurkan untuk kawasan RTH adalah 50 dBA dan kawasan rekreasi 70 dBA. Beberapa kriteria tanaman yang digunakan sebagai peredam bising antara lain: 
K1 = Berdaun tebal (Grey dan Deneke 1978)

K2 = Tajuk rapat, massa daun rapat (DPU Dirjen Bina Marga 1996)

K3 = Struktur cabang dan batang besar (Grey dan Deneke 1978)

K4 = Berdaun jarum (Grey dan Deneke 1978)

Penilaian terhadap fungsi peredam bising berdasarkan keempat kriteria tersebut pada masing-masing taman diuraikan ke dalam Tabel 9, 11, 13 dan 15.

Tabel 9 Penilaian aspek fungsi peredam bising di Taman Ayodya

\begin{tabular}{|c|c|c|c|c|c|c|c|}
\hline \multirow{3}{*}{ Nama Ilmiah } & \multirow{3}{*}{ Nama Lokal } & \multirow{2}{*}{\multicolumn{4}{|c|}{$\begin{array}{l}\text { Kriteria Fungsi Peredam } \\
\text { Bising }\end{array}$}} & \multirow{3}{*}{ Skor } & \multirow{3}{*}{ Kategori } \\
\hline & & & & & & & \\
\hline & & $\mathrm{K} 1$ & $\mathrm{~K} 2$ & K3 & K4 & & \\
\hline \multirow{2}{*}{$\begin{array}{l}\text { Agathis dammara } \\
\text { Arē̄ucaria heterophylla } \\
\cong .\end{array}$} & Damar & 2 & 3 & 3 & 2 & $63 \%$ & Baik \\
\hline & Cemara norflok & 4 & 4 & 2 & 4 & $88 \%$ & Sangat baik \\
\hline Bismarckia nobilis & Bismarck palm & 1 & 3 & 2 & 3 & $56 \%$ & Sedang \\
\hline Borassus flabellifer & Lontar & 2 & 2 & 2 & 3 & $59 \%$ & Sedang \\
\hline Bucida molineti & $\begin{array}{l}\text { Ketapang daun } \\
\text { kecil }\end{array}$ & 2 & 1 & 3 & 1 & $44 \%$ & Sedang \\
\hline Caltistemon citrinus & Sikat botol & 3 & 2 & 2 & 4 & $69 \%$ & Baik \\
\hline $\begin{array}{l}\text { Chrysallidocarpus } \\
\text { lueubensis }\end{array}$ & Palem kuning & 2 & 2 & 2 & 4 & $63 \%$ & Baik \\
\hline Coēos nucifera & Kelapa & 2 & 2 & 2 & 4 & $63 \%$ & Baik \\
\hline Cyrtostachis renda & Palem merah & 3 & 2 & 1 & 4 & $63 \%$ & Baik \\
\hline Ficus benjamina & Beringin & 4 & 3 & 4 & 1 & $75 \%$ & Baik \\
\hline Mimusoph elengi & Tanjung & 3 & 2 & 2 & 1 & $50 \%$ & Sedang \\
\hline Phoenix canariensis & $\begin{array}{l}\text { Canary island } \\
\text { date palm }\end{array}$ & 4 & 3 & 3 & 4 & $88 \%$ & Sangat baik \\
\hline Plümeria rubra & Kamboja & 2 & 2 & 2 & 1 & $44 \%$ & Sedang \\
\hline Polyalthia longifolia & Glodogan tiang & 4 & 1 & 3 & 2 & $63 \%$ & Baik \\
\hline Pterocarpus indicus & Angsana & 2 & 1 & 3 & 1 & $44 \%$ & Sedang \\
\hline Samanea saman & Trembesi & 2 & 1 & 3 & 1 & $44 \%$ & Sedang \\
\hline Tabebuia chrysanta & Tabebuya & 3 & 2 & 2 & 2 & $56 \%$ & Sedang \\
\hline Terminalia catappa & Ketapang & 2 & 3 & 2 & 1 & $50 \%$ & Sedang \\
\hline
\end{tabular}

Penilaian KPI menunjukkan mayoritas tanaman Taman Ayodya berkategori sedang terhadap fungsi peredam bising (Tabel 9). Tanaman berkategori sedang terletak menyebar dan beberapa dijadikan barrier taman. Sebaliknya, tanaman dengan kategori baik dan sangat baik dalam fungsi peredam bising letaknya menyebar, ditanam soliter dan berkelompok di dalam taman. Tanaman kategori baik dan sangat baik digunakan sebagai estetika, screen, pengarah dan peneduh. Cemara norflok (Araucaria heterophylla) dan Canary island date palm (Phoenix canariensis) merupakan tanaman peredam bising kategori sangat baik yang digunakan sebagai estetika dan ditanam secara soliter di dalam taman. Pohon Agathis dammara, Callistemon citrinus, Cocos nucifera merupakan beberapa tanaman kategori baik yang ditaman berkelompok sebagai screen, pengarah dan penaung di dalam taman. Berdasarkan segi penataan, seharusnya tanaman peredam bising kategori baik dan sangat baik diletakkan di tepi taman karena dekat dengan sumber kebisingan dan cenderung efektif dalam meredam bising. 
Tingkat kebisingan juga dinilai dengan pengukuran di lapang. Pengukuran bising di Taman Ayodya dilakukan tiga kali pengulangan yaitu pada hari senin I tanggal 16 Mei 2016, hari sabtu tanggal 21 Mei 2016 dan hari selasa tanggal 28 Juni 2016. Berdasarkan pengukuran, tingkat kebisingan didalam taman dapat f tereduksi hingga 9.2 dBA dibandingkan dengan diluar taman. Tabel 10 $\div$ menunjukkan rekapitulasi hasil pengukuran tingkat kebisingan di Taman Ayodya.

Tabel 10 Rekapitulasi hasil pengukuran tingkat kebisingan di Taman Ayodya

\begin{tabular}{ccccc}
\hline & Pagtu & Siang & Sore \\
\hline Titik ukur(dBA) & & & & \\
\hline Dalam tapak & 1 & 62.3 & 68.3 & 68.2 \\
Luar tapak & 2 & 67.1 & 68.4 & 70.1 \\
$\frac{\Omega}{3}$ & 3 & 64.8 & 64.6 & 67.0 \\
& 4 & 63.8 & 63.1 & 73.9
\end{tabular}

Titik pengukuran bising merupakan sisi terluar taman yang paling mendekati sumber kebisingan, sehingga didapatkan empat titik yang mewakili keseluruhan taman. Titik pertama adalah sisi timur laut taman yang berbatasan dengan Jallan Mahakam yang menggunakan jajaran pohon Borassus flabellifer dan Callistemèn citrinus. Titik kedua adalah sisi tenggara taman yang berbatasan dengan Jẩan Melawai yang menggunakan jajaran pohon Borassus flabellifer dan Callistemon citrinus. Titik ketiga adalah sisi barat daya taman yang berbatasan dengan Taman Langsat yang menggunakan jajaran Mimusoph elengi yang dikombinasikan dengan Acalypha macrophylla. Titik keempat adalah sisi barat laut yang berbatasan dengan Jalan Lamandau II yang menggunakan jajaran Mimusoph elengi yang dikombinasikan dengan Acalypha macrophylla. Hasil pengukurân menunjukkan bahwa Taman Ayodya belum memenuhi baku mutu kebisingan sebagai kawasan RTH namun memenuhi sebagai kawasan rekreasi.

Tabel 11 Penilaian aspek fungsi peredam bising di Taman Martha Tiahahu

\begin{tabular}{|c|c|c|c|c|c|c|c|}
\hline \multirow{3}{*}{ Nama Ilmiah } & \multirow{3}{*}{ Nama Lokal } & \multirow{2}{*}{\multicolumn{4}{|c|}{ Kriteria Fungsi Peredam }} & \multirow{3}{*}{ Skor } & \multirow{3}{*}{ Kategori } \\
\hline & & & & & & & \\
\hline & & $\mathrm{K} 1$ & K2 & K3 & K4 & & \\
\hline Averrhoa carambola & Belimbing & 2 & 1 & 2 & 2 & $44 \%$ & Sedang \\
\hline Bismarckia nobilis & Bismarck palm & 1 & 3 & 2 & 3 & $56 \%$ & Sedang \\
\hline $\begin{array}{l}\text { Chrysalidocarpus } \\
\text { lutescens }\end{array}$ & Palem kuning & 2 & 2 & 2 & 4 & $63 \%$ & Baik \\
\hline Ficus lyrata & Biola cantik & 3 & 3 & 4 & 1 & $69 \%$ & Baik \\
\hline Lagerstromia speciosa & Bungur & 3 & 2 & 2 & 1 & $50 \%$ & Sedang \\
\hline Mangiferaindica & Mangga & 4 & 3 & 2 & 2 & $69 \%$ & Baik \\
\hline Manilkarakauki & Sawo kecik & 3 & 3 & 2 & 1 & $56 \%$ & Sedang \\
\hline $\begin{array}{l}\text { Mascarena } \\
\text { lagenicautis }\end{array}$ & Palem botol & 2 & 3 & 2 & 4 & $69 \%$ & Baik \\
\hline Pinus merkusii Jungh. & Pinus & 1 & 2 & 3 & 4 & $63 \%$ & Baik \\
\hline Polyalthia fragrans & Glodogan bulat & 3 & 1 & 3 & 2 & $56 \%$ & Sedang \\
\hline Pterocarpus indicus & Angsana & 2 & 1 & 3 & 1 & $44 \%$ & Sedang \\
\hline Roystonea regia & Palem raja & 2 & 2 & 2 & 4 & $63 \%$ & Baik \\
\hline
\end{tabular}


Tabel 11 Penilaian aspek fungsi peredam bising di Taman Martha Tiahahu (lanjutan)

\begin{tabular}{|c|c|c|c|c|c|c|c|}
\hline \multirow{3}{*}{ Nama Ilmiah } & \multirow{3}{*}{ Nama Lokal } & \multicolumn{4}{|c|}{ Kriteria Fungsi Peredam } & \multirow{3}{*}{ Skor } & \multirow{3}{*}{ Kategori } \\
\hline & & & & & & & \\
\hline & & K1 & K2 & K3 & K4 & & \\
\hline Sweitenia mahogani & Mahoni & 3 & 2 & 2 & 2 & $56 \%$ & Sedang \\
\hline Terminalia catappa L. & Ketapang & 2 & 3 & 2 & 1 & $50 \%$ & Sedang \\
\hline Veitchia merilii & Palem putri & 2 & 2 & 2 & 4 & $63 \%$ & Baik \\
\hline Wodyetia bifurcata & $\begin{array}{l}\text { Palem ekor } \\
\text { tupai }\end{array}$ & 2 & 2 & 2 & 4 & $63 \%$ & Baik \\
\hline
\end{tabular}

Penilaian KPI menunjukkan mayoritas tanaman Taman Martha tiahahu berkategori baik dan sedang terhadap fungsi peredam bising (Tabel 11). Tanaman denğan kategori baik dalam fungsi peredam bising letaknya menyebar, ditanam solifer dan berkelompok di dalam taman. Tanaman kategori baik digunakan sebägai estetika, peneduh dan pengarah. Pohon Bismarckia nobilis dan Mašcarena lagenicaulis merupakan tanaman peredam bising kategori baik yang ditā̄am soliter dan digunakan sebagai estetika di dalam taman. Pohon Ficus lyräta, Mangifera indica dan Roystonea regia merupakan beberapa tanaman kategori baik yang ditaman berkelompok sebagai peneduh dan pengarah. Pen⿳亠口冋lihan tanaman sudah baik karena pohon yang ada mendapat kategori sedang sampai baik sebagai tanaman peredam bising, namun dapat lebih baik jika pohon ditambah dan dikombinasikan dengan penggunaan semak agar lebih efektif dalam meredam bising.

Pengukuran bising di Taman Martha Tiahahu dilakukan tiga kali pengulangan yaitu pada hari kamis tanggal 19 Mei 2016, hari minggu tanggal 22 Mei 2016 dan hari senin tanggal 23 Mei 2016. Berdasarkan pengukuran, tingkat kebisingan didalam taman dapat tereduksi hingga $6.8 \mathrm{dBA}$ dibandingkan dengan diluar taman. Tabel 12 menunjukkan rekapitulasi hasil pengukuran tingkat kebissingan di Taman Martha Tiahahu.

Tabel 12 Rekapitulasi hasil pengukuran tingkat kebisingan di Taman Martha Tiahahu

\begin{tabular}{lllll}
\hline & & Waktu & & \\
\multicolumn{1}{l}{} & & Pagi & Siang & Sore \\
\hline \multirow{2}{*}{ Titik ukur(dBA) } & & & & 73.8 \\
& 1 & 68.9 & 68.5 & 72.3 \\
& 2 & 61.9 & 70.6 & 70.1 \\
Lalam tapak & 3 & 62.0 & 70.5 & 70.9 \\
& 4 & 64.1 & 65.7 & 76.7 \\
\hline
\end{tabular}

Titik pengukuran bising Taman Martha Tiahahu pertama adalah sisi timur laut taman yang berbatasan dengan Terminal Blok $M$ yang menggunakan jajaran pohon Pterocarpus indicus. Titik kedua adalah sisi tenggara taman yang berbatasan dengan Jalan Melawai X yang menggunakan jajaran pohon Veitchia merilii dan.Pinus merkusii. Titik ketiga adalah sisi barat daya taman yang berbatasan dengan Jalan Panglima Polim Raya yang menggunakan jajaran 
Manilkara kauki. Titik keempat adalah sisi barat laut yang berbatasan dengan Jalan Panglima Polim Raya yang menggunakan jajaran Pinus merkusii. Hasil I pengukuran menunjukkan bahwa Taman Ayodya belum memenuhi baku mutu kebisingan sebagai kawasan RTH maupun kawasan rekreasi.

Tabel 13 Penilaian aspek fungsi peredam bising di Taman Tangkuban Perahu

\begin{tabular}{|c|c|c|c|c|c|c|c|}
\hline \multirow{3}{*}{ Nama Ilmiah } & \multirow{3}{*}{ Nama Lokal } & \multirow{2}{*}{\multicolumn{4}{|c|}{ Kriteria Fungsi Peredam }} & \multirow{3}{*}{ Skor } & \multirow{3}{*}{ Kategori } \\
\hline & & & & & & & \\
\hline & & K1 & $\mathrm{K} 2$ & K3 & K4 & & \\
\hline Araucariaheterophylla & Cemara norflok & 4 & 4 & 2 & 4 & $88 \%$ & Sangat baik \\
\hline Artocarpus communis & Sukun & 2 & 2 & 2 & 2 & $50 \%$ & Sedang \\
\hline $\begin{array}{l}\text { Artocarpus: } \\
\text { heteroph }\end{array}$ & Nangka & 2 & 2 & 3 & 1 & $50 \%$ & Sedang \\
\hline Butia capitata & Jelly palm & 4 & 3 & 4 & 4 & $94 \%$ & Sangat baik \\
\hline Mangiferāindica & Mangga & 4 & 3 & 2 & 2 & $69 \%$ & Baik \\
\hline Manglieti glauca & Manglid & 3 & 3 & 4 & 2 & $75 \%$ & Baik \\
\hline Persea americana & Alpukat & 4 & 3 & 2 & 1 & $63 \%$ & Baik \\
\hline Prunus avium & Ceri & 3 & 1 & 2 & 2 & $50 \%$ & Sedang \\
\hline Pterocarp $\overline{\bar{u}}$ indicus & Angsana & 2 & 1 & 3 & 1 & $44 \%$ & Sedang \\
\hline Samanea saman & Trembesi & 2 & 1 & 3 & 1 & $44 \%$ & Sedang \\
\hline Swieteniamahogani & Mahoni & 3 & 2 & 2 & 2 & $56 \%$ & Sedang \\
\hline Tabebuia ehrysanta & Tabebuya & 3 & 2 & 2 & 2 & $56 \%$ & Sedang \\
\hline Tamarindus indica & Asam jawa & 2 & 1 & 3 & 1 & $44 \%$ & Sedang \\
\hline
\end{tabular}

Penilaian KPI menunjukkan mayoritas tanaman Taman Tangkuban Perahu berkategori sedang terhadap fungsi peredam bising (Tabel 13). Tanaman kategori sangat baik letaknya menyebar, ditanam soliter dan digunakan sebagai estetika. Jumlah tanaman kategori sangat baik hanya 2\% dari total individu pohon yang ada. Pohơ Mangifera indica adalah salah satu tanaman peredam bising kategori baik yang dominan di taman dan ditanam berkelompok. Letak dan jumlah Mangiferê indica sangat berpengaruh terhadap kebisingan yang masuk kedalam taman.

Pengukuran bising di Taman Tangkuban Perahu dilakukan tiga kali pengulangan yaitu pada hari minggu tanggal 15 Mei 2016, hari selasa tanggal 24 Mei 2016 dan hari sabtu tanggal 25 Juni 2016. Berdasarkan pengukuran, tingkat kebisingan didalam taman dapat tereduksi hingga 6.6 dBA dibandingkan dengan diluar taman. Tabel 14 menunjukkan rekapitulasi hasil pengukuran tingkat kebisingan di Taman Tangkuban Perahu.

Tabel 14 Rekapitulasi hasil Pengukuran Tingkat Kebisingan di Taman Tangkuban Perahu

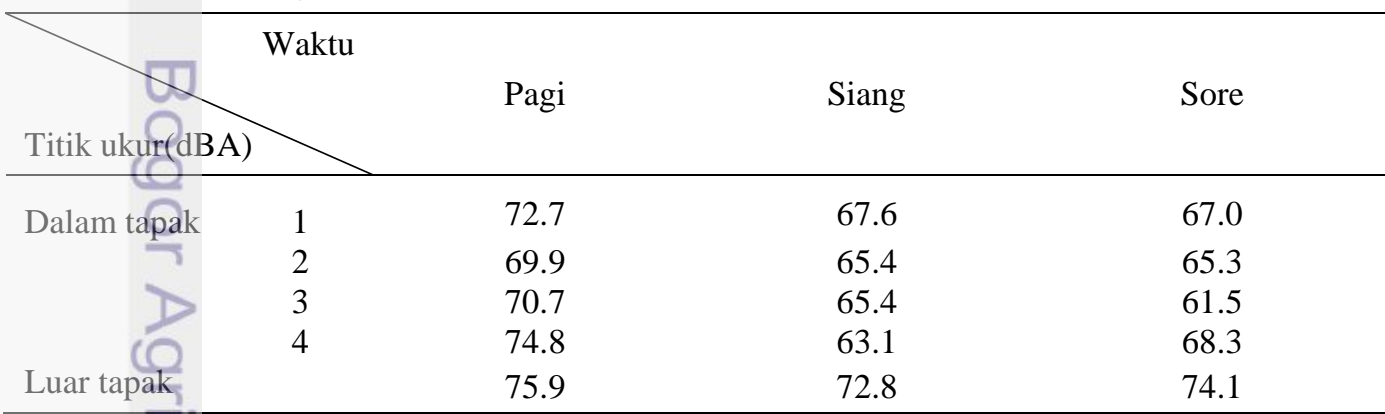


Titik pengukuran bising Taman Tangkuban Perahu pertama adalah sisi utara taman yang berbatasan dengan Jalan Gede yang menggunakan jajaran pohon Mangifera indica. Titik kedua adalah sisi timur taman yang berbatasan dengan Jalan Merbabu yang menggunakan jajaran pohon Mangifera indica. Titik ketiga adalah sisi selatan taman yang berbatasan dengan Jalan Muria yang menggunakan jajaran Mangifera indica. Titik keempat adalah sisi barat yang berbatasan dengan Masjid Tangkuban Perahu yang menggunakan Butia capitata. Hasil pengukuran menunjukkan bahwa Taman Tangkuban Perahu belum memenuhi baku mutu kebisingan sebagai kawasan RTH namun memenuhi sebagai kawasan rekreasi.

Tabel 15 Penilaian aspek fungsi peredam bising di Taman Mataram

\begin{tabular}{|c|c|c|c|c|c|c|c|}
\hline \multirow{3}{*}{$\begin{array}{l}\frac{\bar{T}}{\mathrm{~N}} \\
\text { Nama Ilmiah } \\
\underline{\Omega}\end{array}$} & \multirow{3}{*}{ Nama Lokal } & \multicolumn{4}{|c|}{ Kriteria Fungsi Peredam } & \multirow{3}{*}{ Skor } & \multirow{3}{*}{ Kategori } \\
\hline & & & & & & & \\
\hline & & $\mathrm{K} 1$ & $\mathrm{~K} 2$ & K3 & $\mathrm{K} 4$ & & \\
\hline Alstonia scholaris & Pulai & 3 & 3 & 3 & 1 & $63 \%$ & Baik \\
\hline $\begin{array}{l}\text { Artocarpus } \\
\text { heterophyllus }\end{array}$ & Nangka & 2 & 2 & 3 & 1 & $50 \%$ & Sedang \\
\hline Cätistemon citrinus & Sikat botol & 3 & 2 & 2 & 4 & $69 \%$ & Baik \\
\hline Ficus benjamina & Beringin & 4 & 3 & 4 & 1 & $75 \%$ & Baik \\
\hline Mimusops elengi & Tanjung & 3 & 2 & 2 & 1 & $50 \%$ & Sedang \\
\hline Phoenix canariensis & $\begin{array}{l}\text { Canary island } \\
\text { date palm }\end{array}$ & 4 & 3 & 3 & 4 & $88 \%$ & Sangat baik \\
\hline Potyalthia fragrans & Glodogan bulat & 3 & 1 & 3 & 2 & $56 \%$ & Sedang \\
\hline Pterocarpus indicus & Angsana & 2 & 1 & 3 & 1 & $44 \%$ & Sedang \\
\hline Samanea saman & Trembesi & 2 & 1 & 3 & 1 & $44 \%$ & Sedang \\
\hline Sweitenia mahogani & Mahoni & 3 & 2 & 2 & 2 & $56 \%$ & Sedang \\
\hline Tabebuia chrysanta & Tabebuya & 3 & 2 & 2 & 2 & $56 \%$ & Sedang \\
\hline Terminalia catappa $\mathrm{L}$. & Ketapang & 2 & 3 & 2 & 1 & $50 \%$ & Sedang \\
\hline
\end{tabular}

Penilaian KPI menunjukkan mayoritas tanaman Taman Mataran berkategori sedang terhadap fungsi peredam bising (Tabel 15). Tanaman berkategori sedang terletak menyebar dan ditanam soliter di dalam taman. Tanaman kategori sangat baik (Phoenix canariensis) letaknya menyebar, ditanam soliter dan digunakan sebagai barrier. Jumlah tanaman kategori sangat baik merupakan tanaman dominan di taman ini.

Pengukuran bising di Taman Mataram dilakukan tiga kali pengulangan yaitu pada hari rabu tanggal 18 Mei 2016, hari minggu tanggal 26 Juni 2016 dan hari senin tanggal 27 Juni 2016. Berdasarkan pengukuran, tingkat kebisingan didalam taman dapat tereduksi hingga 5.6 dBA dibandingkan dengan diluar taman. Tabel 16 menunjukkan rekapitulasi hasil pengukuran tingkat kebisingan di Taman Mataram.

Tabel 16 Rekapitulasi hasil pengukuran tingkat kebisingan di Taman Mataram

\begin{tabular}{lllll} 
Titik ukur(dBA) & Pagi & Siang & Sore \\
\hline Dałam tapak & 1 & & & 66.1 \\
\hline
\end{tabular}




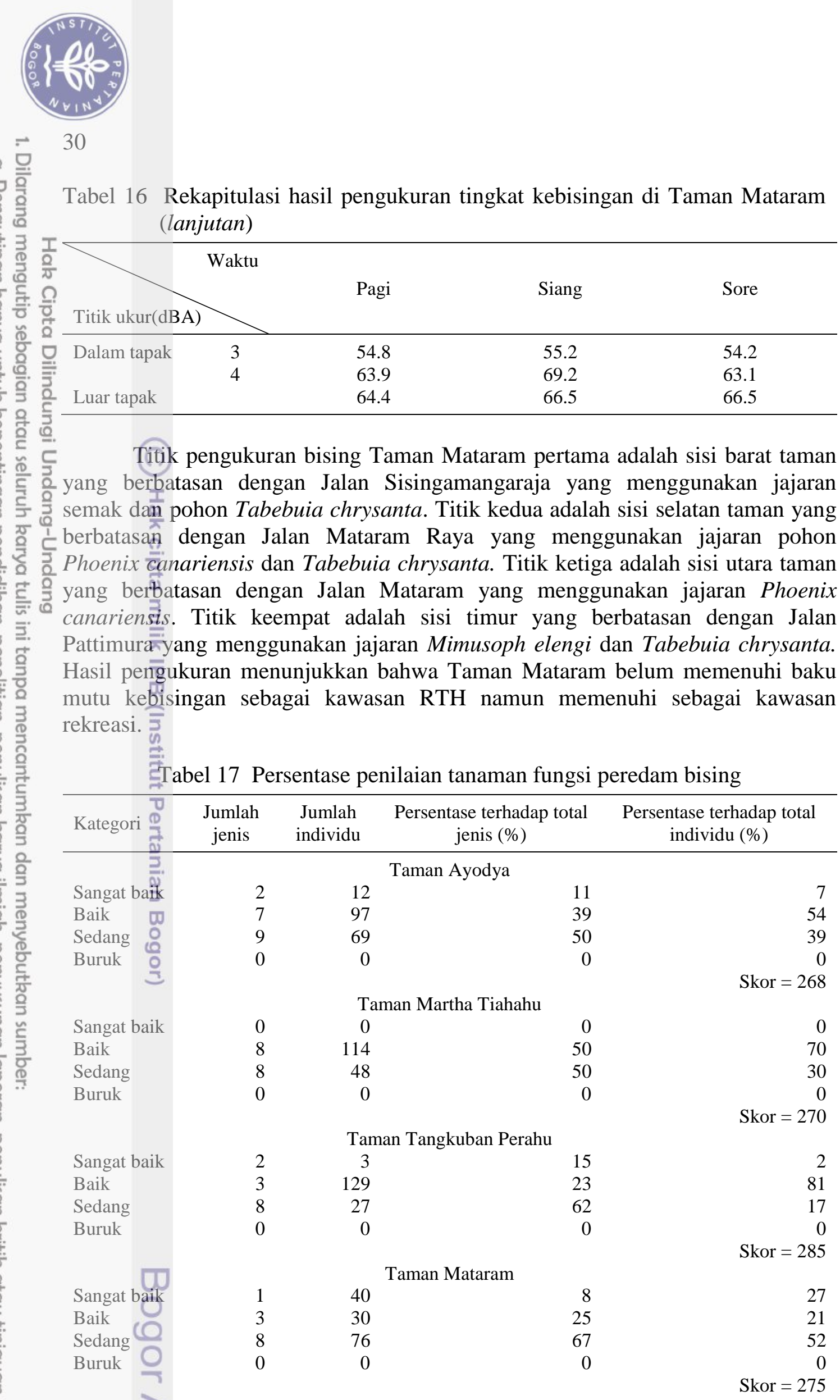


Tabel 18 Selisih tingkat kebisingan yang dapat direduksi

\begin{tabular}{|c|c|c|c|c|c|}
\hline Titik ukur(dBA) & Taman & $\begin{array}{c}\text { Taman } \\
\text { Ayodya }\end{array}$ & $\begin{array}{l}\text { Taman } \\
\text { Martha } \\
\text { Tiahahu }\end{array}$ & $\begin{array}{c}\text { Taman } \\
\text { Tangkuban } \\
\text { Perahu }\end{array}$ & $\begin{array}{c}\text { Taman } \\
\text { Mataram }\end{array}$ \\
\hline \multirow[t]{3}{*}{ Dalam tapak } & $\mathrm{P} 1 *$ & 64,5 & 64,2 & 72 & 59,7 \\
\hline & $\mathrm{P} 2$ & 66,1 & 68,8 & 65,4 & 61,3 \\
\hline & P3 & 67 & 71,8 & 65,5 & 59,4 \\
\hline Rata-rata & & 65,9 & 68,3 & 67,6 & 60,1 \\
\hline Luar tapak & & 75,1 & 75,1 & 74,2 & 65,7 \\
\hline Selisih & & $-9,2$ & $-6,8$ & $-6,6$ & $-5,6$ \\
\hline
\end{tabular}

* P1, P2, dan P3 merupakan waktu pengambilan data dari 12 titik di dalam taman

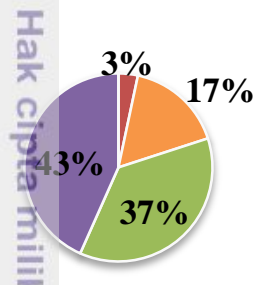

(a)

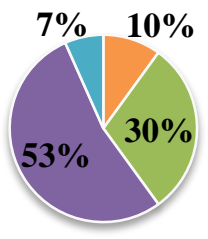

(b)

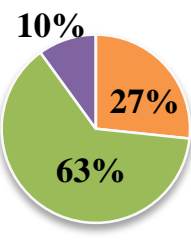

(c)

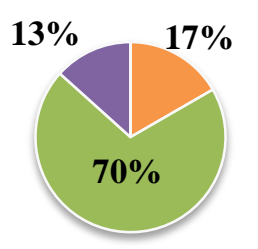

- Sangat tenang

- Tenang

$\square$ Sedang

- Bising

- Sangat bising

(d)

Gambar 12 Persentase persepsi responden tentang kebisingan di (a) Taman Ayodya, (b) Taman Martha Tiahahu, (c) Taman Tangkuban Perahu dan (d) Taman Mataram

Hasil penilaian berdasarkan vegetasi keseluruhan menunjukkan taman dengan nilai fungsi peredam bising terbaik adalah Taman Tangkuban Perahu (Tabel 17). Hasil tersebut tidak sejalan dengan pengukuran tingkat kebisingan di lapầng (Tabel 18). Jika dibandingkan dengan persepsi masyarakat terhadap kebisingan, hasil penilaian vegetasi sejalan yaitu Taman Tangkuban Perahu adaPah taman yang lebih tenang diantara keempat taman (Gambar 12). Hal ini disebabkan oleh beberapa faktor seperti letak dan jarak tanaman ke sumber kebisingan, frekuensi kendaraan yang berada disekitar, dan komposisi/penataan tanaman sebagai barrier.

\subsubsection{Fungsi modifikasi suhu (peneduh)}

Menurut Booth (1983) suhu udara di dalam bayang-bayang kanopi ini dapat lebih rendah $8^{\circ} \mathrm{C}$ daripada suhu udara di ruang terbuka. Pohon-pohon besar yang bertajuk lebar sangatlah efektif sebagai peneduh karena daun pepohonan tersebut dapat menahan, mencerminkan, mengabsorpsi, dan membawa radiasi matahari (Grey dan Deneke 1978). Aktivitas di taman kota umumnya dilakukan pada pagi hingga sore hari saat radiasi matahari masih sangat tinggi. Untuk itu keberadaan tanaman peneduh sangat dibutuhkan khususnya di taman kota.

Beberapa kriteria tanaman yang digunakan sebagai peneduh antara lain:

$\mathrm{K} d=$ Bentuk tajuk spreading, bulat, dome, irregular (DPU Dirjen Bina Marga 1996)

K2 = Massa daun rapat (DPU Dirjen Bina Marga 1996)

K3 $\Rightarrow$ Ketinggian kanopi lebih dari 2 m (Simonds 1983)

$\mathrm{K} 4=$ Berdaun tebal (Carpenter et al. 1975) 
Penilaian terhadap fungsi modifikasi suhu (peneduh) berdasarkan keempat

a tersebut pada masing-masing taman diuraikan ke dalam Tabel 19, 21, 23

I dan 25

Tabel 19 Penilaian aspek fungsi modifikasi suhu (peneduh) di Taman Ayodya

Kriteria Fungsi

Nama Ilmiah Nama Lokal Nodifikasi Suhu

\begin{tabular}{llccccccc} 
& & K1 & K2 & K3 & K4 & & & \\
\hline Agathis dammara & Damar & 2 & 1 & 3 & 3 & $56 \%$ & Sedang
\end{tabular}

Araucaria heterophylla

Bismarckia nobilis

Borassus flabellifer

Cemara norflok

$69 \%$ Baik

$\begin{array}{lllllll}\text { Bismarck palm } & 1 & 4 & 2 & 3 & 63 \% & \text { Baik }\end{array}$

Bucida molineti

Lontar

Ketapang daun

$69 \%$ Baik

kecil

Callistemon citrinus

Chrysallidocarpus

Sikat botol

Palem kuning

Kelapa

Cocos nuêtfera

Cyrtostachis renda

Ficus benfamina

Mimusophelengi

Phoenix canariensis

in

Plumeria Fubra

Polyalthiälongifolia

Pterocarpus indicus

Palem merah

Beringin

Tanjung

Canary island

date palm

Kamboja

Glodogan tiang

Angsana

Trembesi

Samanea Saman

Tabebuia ç hrysanta

Tabebuya

$\begin{array}{lll}4 & 4 & 2\end{array}$

1

$69 \%$ Baik

Terminaliż.catappa

Ketapang

Penilaian KPI menunjukkan $88 \%$ tanaman Taman Ayodya berkategori baik sampai sangat baik terhadap fungsi modifikasi suhu (peneduh) (Tabel 19). Tanaman dengan kategori baik dan sangat baik dalam fungsi modifikasi suhu letaknya menyebar, ditanam soliter dan berkelompok di dalam taman. Tanaman kategori baik juga digunakan sebagai estetika dan pengarah. Pohon Ficus benjamina merupakan pohon dengan skor tertinggi di taman untuk fungsi modifikasi suhu yaitu 94\%.

Pengukuran suhu di Taman Ayodya dilakukan tiga kali pengulangan yaitu pada hari senin tanggal 16 Mei 2016, hari sabtu tanggal 21 Mei 2016 dan hari selasa tanggal 28 Juni 2016. Berdasarkan pengamatan, suhu udara rata-rata di atas rumput di bawah pohon mempunyai suhu terendah diantara titik pengukuran lain di dalam taman dan mampu mereduksi suhu hingga $2.7^{\circ} \mathrm{C}$ dibandingkan dengan suhu luar taman. Suhu di atas rumput tanpa naungan dekat badan air mampu mereduksi suhu $0.1^{\circ} \mathrm{C}$ dibanding suhu di atas rumput tanpa naungan jauh dari badan air. Hasil pengukuran suhu di atas perkerasan mempunyai nilai suhu tertinggi diantara titik pengukuran lain di dalam taman (Lampiran 10). Tabel 20 adalah rekapitulasi hasil pengukuran suhu di Taman Ayodya. 
Tabel 20 Rekapitulasi hasil pengukuran suhu di Taman Ayodya

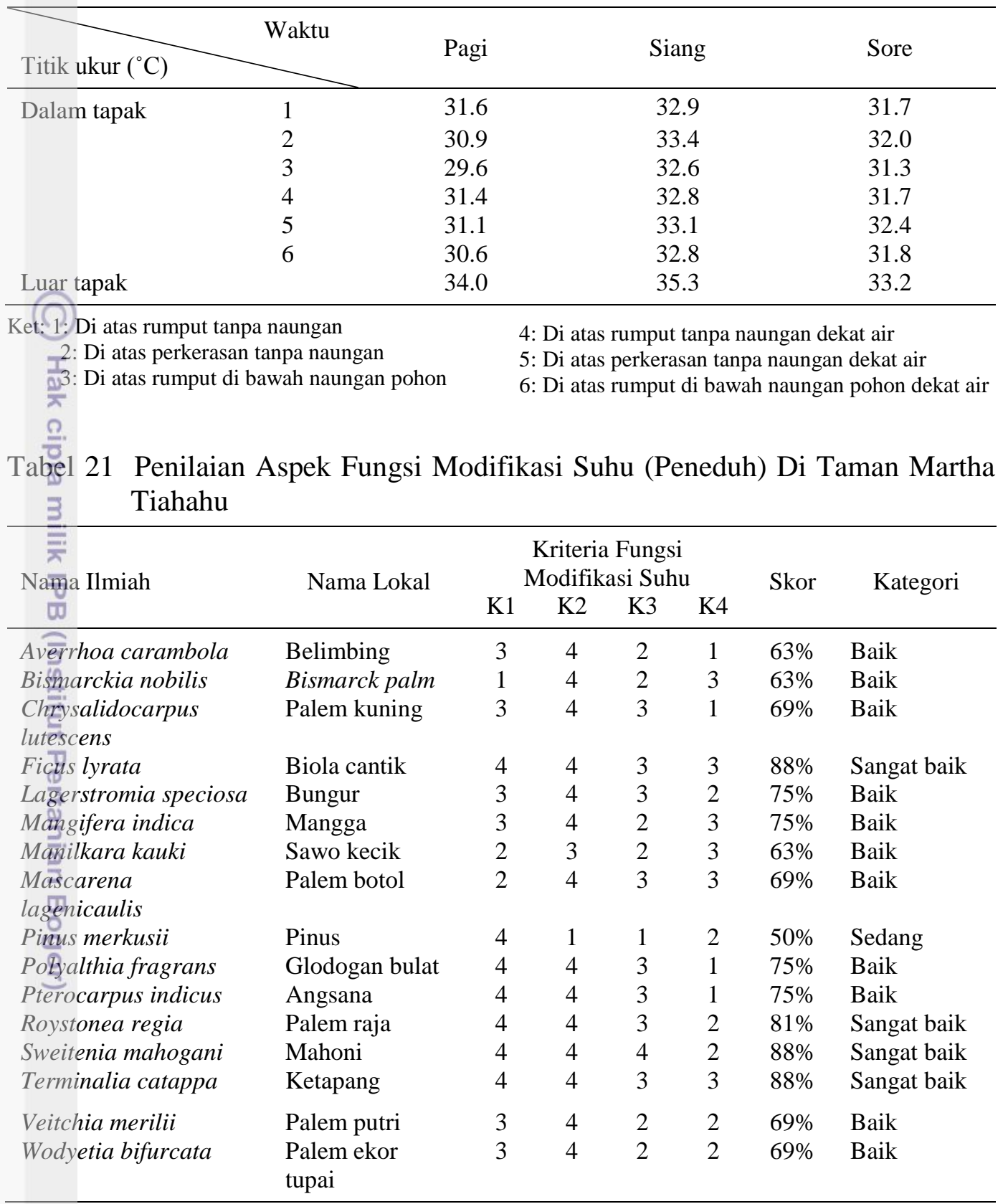

Penilaian KPI menunjukkan mayoritas tanaman Taman Martha Tiahahu berkategori baik terhadap fungsi modifikasi suhu (peneduh) (Tabel 21). Tanaman dengan kategori baik letaknya menyebar, ditanam soliter dan berkelompok di dalam taman. Tanaman kategori baik dan sangat baik juga digunakan sebagai estetika dan pengarah. Pohon Sweitenia mahogani dan Terminalia catappa merupakan pohon dengan skor tertinggi di taman ini yaitu $88 \%$.

Pengukuran suhu di Taman Martha Tiahahu dilakukan tiga kali pengulangan yaitu pada hari kamis tanggal 19 Mei 2016, hari minggu tanggal 22 Mei 2016 dan hari senin tanggal 23 Mei 2016. Berdasarkan pengamatan, suhu udara rata-rata di atas rumput di bawah pohon mempunyai suhu terendah diantara 
titik pengukuran lain di dalam taman dan mampu mereduksi suhu hingga $1.6^{\circ} \mathrm{C}$ dibandingkan dengan suhu luar taman. Suhu di atas rumput tanpa naungan jauh I dari badan air mampu mereduksi suhu $0.1^{\circ} \mathrm{C}$ dibanding suhu di atas rumput tanpa naungan dekat badan air. Hasil pengukuran suhu di atas perkerasan mempunyai f nilai suhu tertinggi diantara titik pengukuran lain di dalam taman (Lampiran 11). Tabel 22 adalah tabel rekapitulasi hasil pengukuran suhu di Taman Martha 을 Tiahahu.

Tabel 22 Rekapitulasi hasil pengukuran suhu di Taman Martha Tiahahu

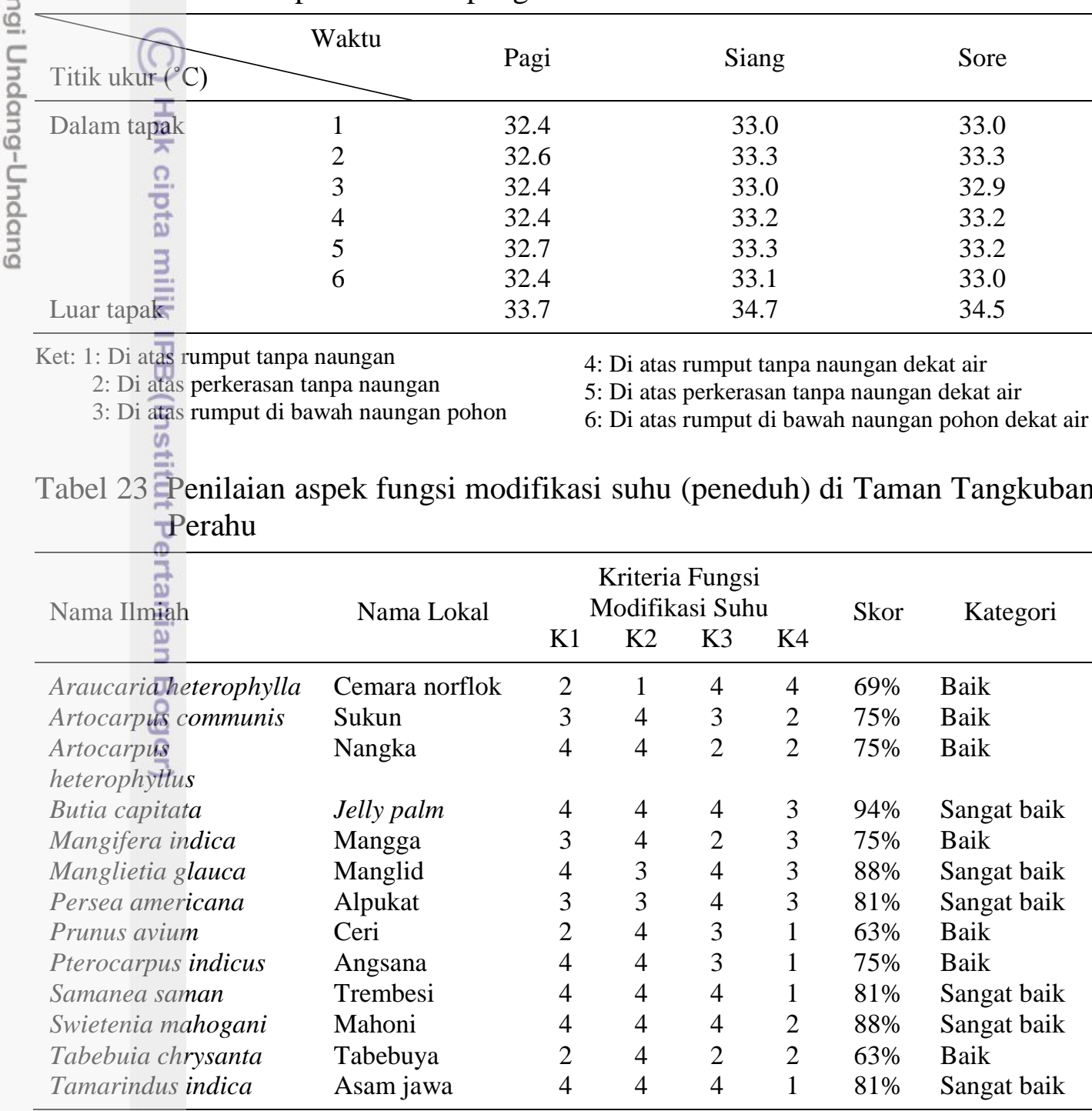

Penilaian KPI menunjukkan tanaman Taman Tangkuban Perahu berkategori diatas baik terhadap fungsi modifikasi suhu (peneduh) (Tabel 23). Tanaman-dengan kategori sangat baik letaknya menyebar, ditanam soliter dengan jumlah individu pohon yang tidak banyak. Pohon Butia capitata merupakan pohon dengan skor tertinggi di taman ini yaitu 94\%.

Pengukuran suhu di Taman Tangkuban Perahu dilakukan tiga kali pengulangan yaitu pada hari minggu tanggal 15 Mei 2016, hari selasa tanggal 24 
Mei 2016 dan hari sabtu tanggal 25 Juni 2016. Berdasarkan pengamatan, suhu udara rata-rata di atas rumput di bawah pohon mempunyai suhu terendah diantara titik pengukuran lain di dalam taman dan mampu mereduksi suhu hingga $1.5^{\circ} \mathrm{C}$ dibandingkan dengan suhu luar taman. Suhu di atas rumput tanpa naungan mampu mereduksi suhu $0.2^{\circ} \mathrm{C}$ dibanding suhu di atas perkerasan di dalam taman (Lampiran 12). Tabel 24 adalah rekapitulasi hasil pengukuran suhu di Taman Tangkuban Perahu.

Tabel 24 Rekapitulasi hasil pengukuran suhu di Taman Tangkuban Perahu

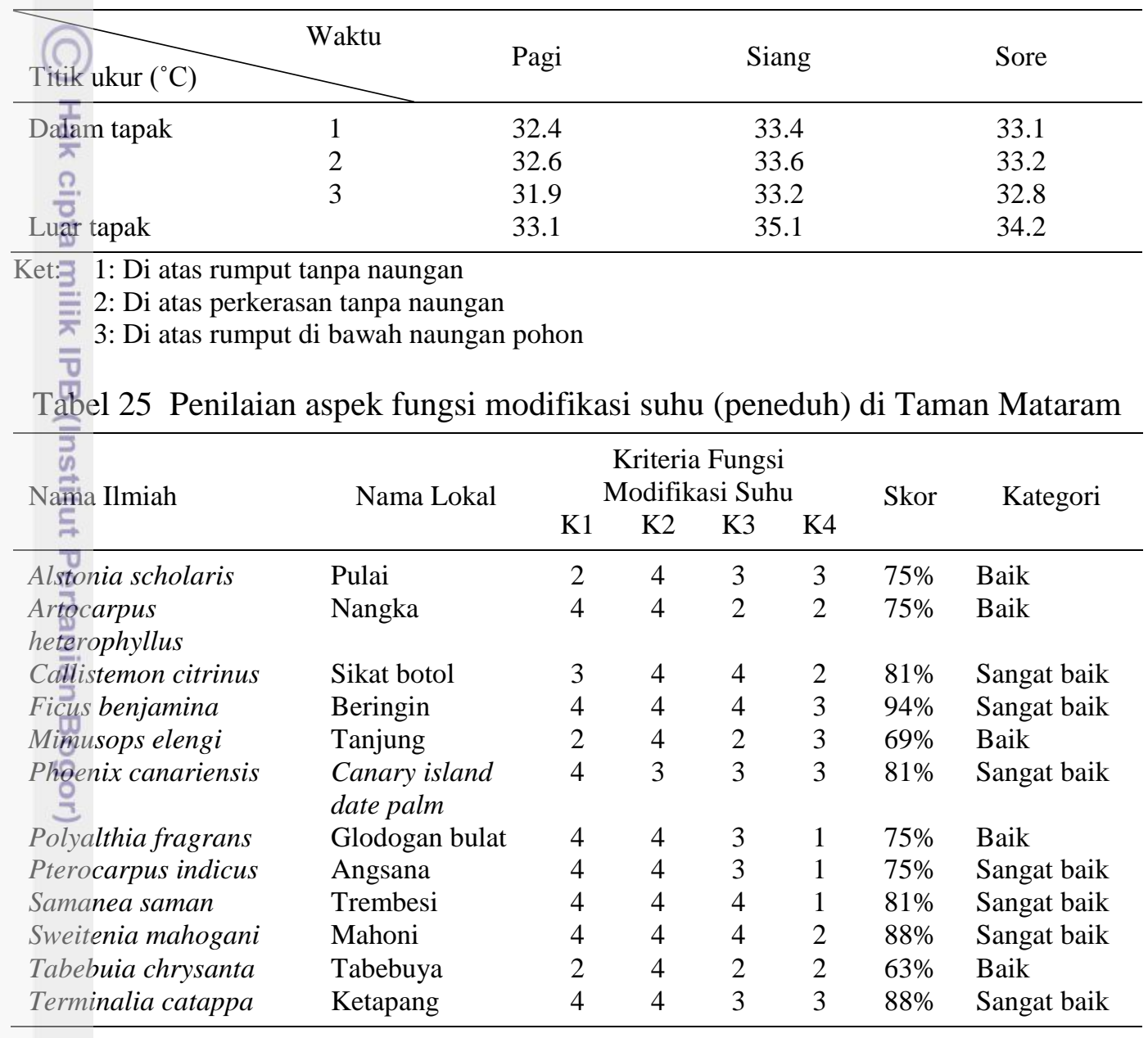

Penilaian KPI menunjukkan mayoritas tanaman Taman Mataram berkategori sangat baik terhadap fungsi modifikasi suhu (peneduh) (Tabel 25). Tanaman dengan kategori sangat baik letaknya menyebar, ditanam soliter dan berkelompok. Selain sebagai peneduh, tanaman berkategori sangat baik juga digunakan sebagai pengarah, barrier, dan estetika taman. Sama seperti di Taman Ayodya, Pohon Ficus benjamina merupakan pohon dengan skor tertinggi di taman ini yaitu $94 \%$.

Pengukuran suhu di Taman Mataram dilakukan tiga kali pengulangan yaitu pada hari rabu tanggal 18 Mei 2016, hari minggu tanggal 26 Juni 2016 dan hari senin tanggal 27 Juni 2016. Berdasarkan pengamatan, suhu udara rata-rata di atas rumput di bawah pohon mempunyai suhu terendah diantara titik pengukuran 


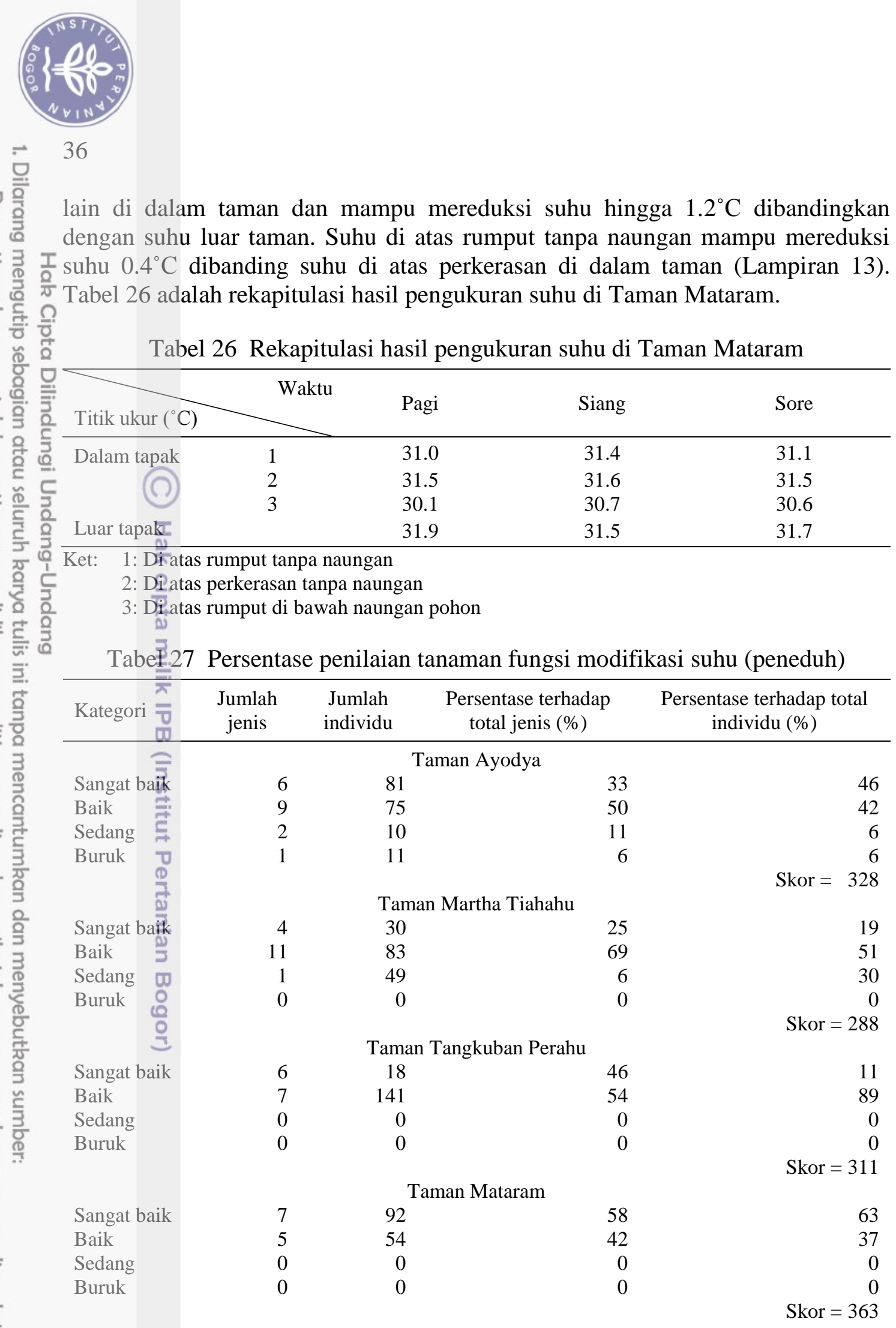

Tabel 28 Selisih tingkat modifikasi suhu (peneduh) yang dapat direduksi di taman Odengan elemen air

\begin{tabular}{lccc} 
& & \\
Titik ukur $\left({ }^{\circ} \mathrm{C}\right)$ & Taman Ayodya & Taman Martha Tiahahu \\
\hline Dalam tapak & $\mathrm{P} 1^{*}$ & 31.0 & 32.5 \\
& $\mathrm{P} 2$ & 33.0 & 33.2 \\
\hline
\end{tabular}


Tabel 28 Selisih tingkat modifikasi suhu (peneduh) yang dapat direduksi di taman dengan elemen air (lanjutan)

\begin{tabular}{lccc} 
& Taman & Taman Ayodya & Taman Martha Tiahahu \\
Titik ukur $\left({ }^{\circ} \mathrm{C}\right)$ & & & \\
\hline Dalam tapak & P3 & 33.1 & 33.2 \\
Rata-rata & & 32.4 & 32.9 \\
Luar tapak & & -1.8 & 34.3 \\
Selisih & & -1.3 \\
\hline
\end{tabular}

* P1, P2, dan P3 merupakan waktu pengambilan data dari 72 titik di dalam taman

Tabel 29 Selisih tingkat modifikasi suhu (peneduh) yang dapat direduksi di taman tanpa elemen air

\begin{tabular}{|c|c|c|c|}
\hline Titik ukur $\left({ }^{\circ} \mathrm{C}\right.$ & Taman & Taman Tangkuban Perahu & Taman Mataram \\
\hline Dafam tapak & P1* & 32.3 & 30.7 \\
\hline$\overline{\bar{\lambda}}$ & $\mathrm{P} 2$ & 33.4 & 31.3 \\
\hline $\bar{\nabla}$ & P3 & 33.0 & 31.1 \\
\hline Ratä-rata & & 32.9 & 31.0 \\
\hline Luât tapak & & 34.1 & 31.1 \\
\hline Selisih & & -1.2 & -0.1 \\
\hline
\end{tabular}

* PE $\mathrm{P} 2$, dan $\mathrm{P} 3$ merupakan waktu pengambilan data dari 36 titik di dalam taman

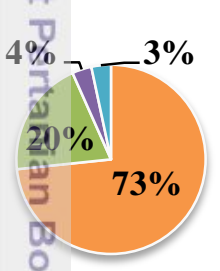

(a)

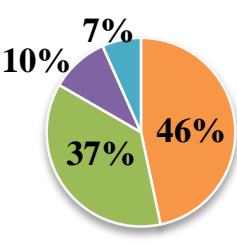

(b)

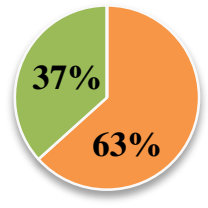

(c)

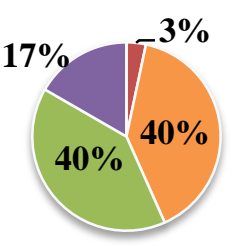

(d)

Gambar 13 Persentase persepsi responden tentang suhu udara di (a) Taman Ayodya, (b) Taman Martha Tiahahu, (c) Taman Tangkuban Perahu dan (d) Taman Mataram

Hasil penilaian berdasarkan pohon keseluruhan menunjukkan taman dengan nilai fungsi modifikasi suhu (peneduh) terbaik adalah Taman Ayodya (Tabel 26). Hasil tersebut sejalan dengan pengukuran tingkat modifikasi suhu (peneduh) di lapang (Tabel 29). Persepsi responden juga menunjukkan Taman Ayodya paling sejuk. Berbeda dengan taman tanpa elemen air, selisih suhu didalam dan diluar taman lebih kecil karena taman yang dilengkapi elemen air mampu menurunkan suhu 0.1-0.6 ${ }^{\circ} \mathrm{C}$. Elemen air dapat meningkatkan kelembaban dan akan berdampak pada penurunan suhu disekitarnya.

5.2.3 Fungsi kontrol kelembaban udara

Kelembaban udara sangat berpengaruh terhadap kenyamanan thermal bagi manusia. Kelembaban yang tinggi menyebabkan kondisi yang tidak nyaman bagi manusia. Kelembaban udara ideal manusia untuk dapat beraktivitas dengan 
nyaman adalah sekitar 40-75\% (Laurie, 1986). Tanaman dibutuhkan untuk meningkatkan evaporasi sehingga kelembaban udara di bawah kanopi dapat I menurun.

Beberapa kriteria tanaman yang digunakan sebagai pengontrol kelembaban udara antara lain:

K1 = Kerapatan daun rendah (Bianpoen et al. 1989)

K2 = Berdaun jarum atau kasar (Grey dan Deneke 1978)

K3 = Tekstur batang kasar (Grey dan Deneke 1978)

K4 = Jumlah daun banyak (Carpenter et al. 1975)

Penilaian terhadap fungsi kontrol kelembaban udara berdasarkan keempat

kriteria tersebut pada masing-masing taman diuraikan ke dalam Tabel 30, 32, 34

dan 36.

\begin{tabular}{llllllll} 
Tabel 30 Penilaian aspek fungsi kontrol kelembaban udara di Taman Ayodya \\
\hline
\end{tabular}

Penilaian KPI menunjukkan mayoritas tanaman Taman Ayodya berkategori sedang terhadap fungsi kontrol kelembaban udara (Tabel 30). Tanaman dengan kategori baik dan sangat baik dalam fungsi kontrol kelembaban udara letaknya menyebar, ditanam soliter dan berkelompok di dalam taman. Tanamankategori baik juga digunakan sebagai estetika, peneduh dan pengarah. Pohon Phoenix canariensis merupakan pohon berkategori sangat baik dengan skor tertinggi di taman untuk fungsi kontrol kelembaban yaitu $81 \%$.

Pengukuran kelembaban udara di Taman Ayodya dilakukan tiga kali pengulangan yaitu pada hari senin tanggal 16 Mei 2016, hari sabtu tanggal 21 Mei 2016 dan hari selasa tanggal 28 Juni 2016. Berdasarkan pengamatan, kelembaban udara rata-rata di atas rumput di bawah pohon dekat air mempunyai kelembaban 
tertinggi diantara titik pengukuran lain di dalam taman dan mampu menaikkan kelembaban hingga 6\% dibandingkan dengan kelembaban luar taman. Kelembaban di atas rumput tanpa naungan dekat badan air mampu menaikkan kelembaban $1 \%$ dibanding kelembaban di atas rumput tanpa naungan jauh dari badan air. Hasil pengukuran kelembaban di atas perkerasan mempunyai nilai kelembaban terrendah diantara titik pengukuran lain di dalam taman (Lampiran 14). Tabel 31 adalah rekapitulasi hasil pengukuran kelembaban udara di Taman Ayodya.

Tabel 31 Rekapitulasi hasil pengukuran kelembaban udara di Taman Ayodya

\begin{tabular}{|c|c|c|c|c|}
\hline Titīk ukur (\%) & Waktu & Pagi & Siang & Sore \\
\hline Dalam tapak & 1 & 70 & 68 & 68 \\
\hline$\frac{7}{0}$ & 2 & 72 & 68 & 69 \\
\hline त) & 3 & 71 & 69 & 69 \\
\hline 3 & 4 & 71 & 69 & 69 \\
\hline 를 & 5 & 68 & 69 & 69 \\
\hline 玄 & 6 & 67 & 70 & 70 \\
\hline Luār tapak & & 67 & 62 & 65 \\
\hline
\end{tabular}

Ket: I: Di atas rumput tanpa naungan

2: Di atas perkerasan tanpa naungan

4: Di atas rumput tanpa naungan dekat air

5: Di atas perkerasan tanpa naungan dekat air

Di atas rumput di bawah naungan pohon

6: Di atas rumput di bawah naungan pohon dekat air

Tabē 32 Penilaian aspek fungsi kontrol kelembaban udara di Taman Martha Tiahahu

\begin{tabular}{|c|c|c|c|c|c|c|c|}
\hline \multirow{2}{*}{ Nama Ilmiah } & \multirow[t]{2}{*}{ Nama Lokal } & \multicolumn{4}{|c|}{$\begin{array}{l}\text { Kriteria Fungsi Kontrol } \\
\text { Kelembaban Udara }\end{array}$} & \multirow[t]{2}{*}{ Skor } & \multirow[t]{2}{*}{ Kategori } \\
\hline & & K1 & $\mathrm{K} 2$ & K3 & K4 & & \\
\hline Averrhoa carambola & Belimbing & 2 & 2 & 2 & 3 & $56 \%$ & Sedang \\
\hline Bismarckia nobilis & Bismarck palm & 3 & 3 & 4 & 1 & $69 \%$ & Baik \\
\hline $\begin{array}{l}\text { Chrysalidocarpus } \\
\text { lutescens }\end{array}$ & Palem kuning & 2 & 4 & 3 & 2 & $69 \%$ & Baik \\
\hline Ficus lyrata & Biola cantik & 1 & 1 & 2 & 3 & $44 \%$ & Sedang \\
\hline Lagerstromia speciosa & Bungur & 1 & 1 & 2 & 3 & $44 \%$ & Sedang \\
\hline Mangifera indica & Mangga & 1 & 2 & 2 & 3 & $50 \%$ & Sedang \\
\hline Manilkara kauki & Sawo kecik & 2 & 1 & 3 & 3 & $56 \%$ & Sedang \\
\hline $\begin{array}{l}\text { Mascarena } \\
\text { lagenicaulis }\end{array}$ & Palem botol & 2 & 4 & 2 & 2 & $63 \%$ & Baik \\
\hline Pinus merkusii & Pinus & 4 & 4 & 3 & 3 & $88 \%$ & Sangat baik \\
\hline Polyalthia fragrans & Glodogan bulat & 1 & 2 & 2 & 3 & $50 \%$ & Sedang \\
\hline Pterocarpus indicus & Angsana & 1 & 1 & 2 & 3 & $44 \%$ & Sedang \\
\hline Roystonea regia & Palem raja & 2 & 4 & 2 & 2 & $63 \%$ & Baik \\
\hline Sweitenia mahogani & Mahoni & 1 & 2 & 2 & 3 & $50 \%$ & Sedang \\
\hline Terminalia catappa & Ketapang & 1 & 1 & 3 & 3 & $50 \%$ & Sedang \\
\hline Veitchia merilii & Palem putri & 2 & 4 & 3 & 2 & $69 \%$ & Baik \\
\hline Wodyetia bifurcata & $\begin{array}{l}\text { Palem ekor } \\
\text { tupai }\end{array}$ & 2 & 4 & 3 & 2 & $69 \%$ & Baik \\
\hline
\end{tabular}

Sama seperti Taman Ayodya, Penilaian KPI menunjukkan mayoritas tanaman Taman Martha Tiahahu berkategori sedang terhadap fungsi kontrol 
kelembaban udara (Tabel 32). Tanaman dengan kategori baik dan sangat baik dalam fungsi kontrol kelembaban udara letaknya menyebar, ditanam soliter dan I berkelompok di dalam taman. Tanaman kategori baik juga digunakan sebagai estetika, peneduh dan pengarah. Pohon Pinus merkusii yang dominan di taman ini masuk dalam kategori sangat baik dengan skor tertinggi di taman untuk fungsi kontrol kelembaban yaitu $88 \%$.

Pengukuran kelembaban udara di Taman Martha Tiahahu dilakukan tiga kali pengulangan yaitu pada hari kamis tanggal 19 Mei 2016, hari minggu tanggal 22 Mei 2016 dan hari senin tanggal 23 Mei 2016. Berdasarkan pengamatan, . kelembaban udara rata-rata di atas rumput di bawah pohon mempunyai $\subsetneq$ kelembaban tertinggi diantara titik pengukuran lain di dalam taman dan mampu menaikkan kelembaban hingga 3\% dibandingkan dengan kelembaban luar taman. Kelembab̆an di atas rumput tanpa naungan jauh dari badan air mampu menaikkan $\subsetneq$ kelembaban $1 \%$ dibanding kelembaban di atas rumput tanpa naungan dekat badan air. Hasi pengukuran kelembaban di atas perkerasan mempunyai nilai kelembaban terrendah diantara titik pengukuran lain di dalam taman (Lampiran 15). Tabet 33 adalah rekapitulasi hasil pengukuran kelembaban udara di Taman Martha Tî̀ahahu.

Tabel $33^{\text {m }}=$ Rekapitulasi hasil pengukuran kelembaban udara di Taman Martha Tiahahu

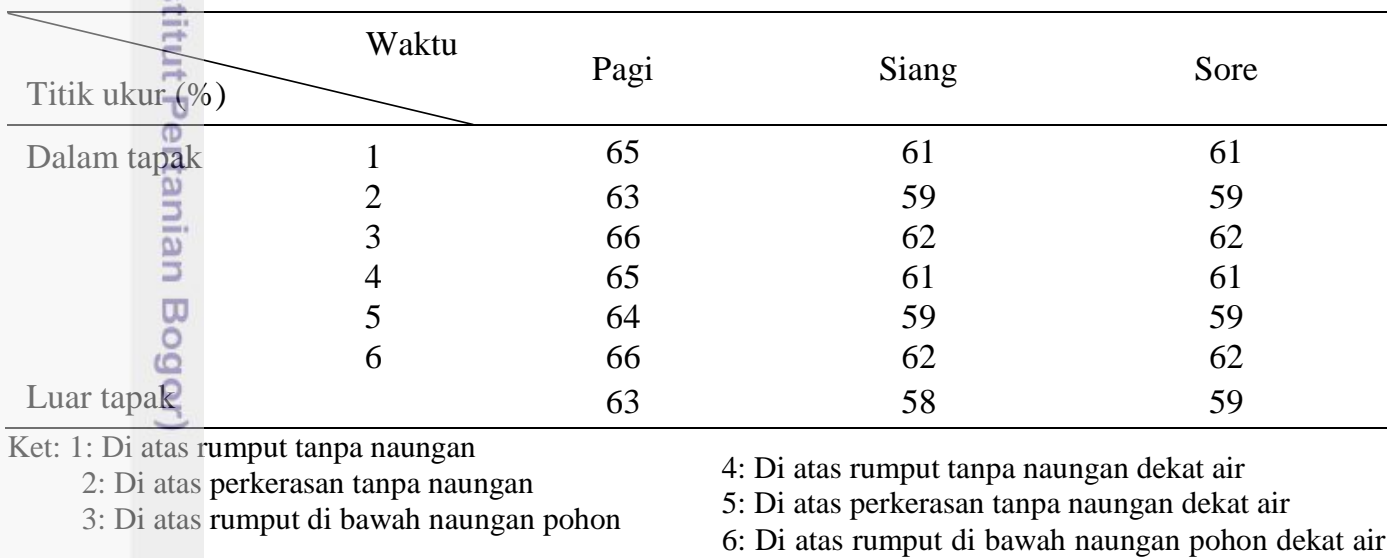

Tabel 34 Penilaian aspek fungsi kontrol kelembaban udara di Taman Tangkuban Perahu

\begin{tabular}{|c|c|c|c|c|c|c|c|}
\hline \multirow{2}{*}{ Nama Ilmiah } & \multirow{2}{*}{ Nama Lokal } & \multicolumn{4}{|c|}{$\begin{array}{l}\text { Kriteria Fungsi Kontrol } \\
\text { Kelembaban Udara }\end{array}$} & \multirow{2}{*}{ Skor } & \multirow{2}{*}{ Kategori } \\
\hline & & K1 & K2 & K3 & K4 & & \\
\hline Araucaria heterophylla & Cemara norflok & 4 & 4 & 2 & 4 & $88 \%$ & Sangat baik \\
\hline Artocarpus communis & Sukun & 1 & 2 & 2 & 3 & $50 \%$ & Sedang \\
\hline $\begin{array}{l}\text { Artocarpus } \\
\text { heterophyllus }\end{array}$ & Nangka & 1 & 1 & 4 & 4 & $63 \%$ & Baik \\
\hline Butia capitata & Jelly palm & 1 & 4 & 4 & 3 & $75 \%$ & Baik \\
\hline Mangiferaindica & Mangga & 1 & 2 & 2 & 3 & $50 \%$ & Sedang \\
\hline Manglietia glauca & Manglid & 1 & 2 & 2 & 3 & $50 \%$ & Sedang \\
\hline Persea americana & Alpukat & 1 & 1 & 2 & 3 & $44 \%$ & Sedang \\
\hline Prunus avium & Ceri & 1 & 2 & 2 & 4 & $56 \%$ & Sedang \\
\hline Pterocarpus indicus & Angsana & 1 & 1 & 2 & 3 & $44 \%$ & Sedang \\
\hline
\end{tabular}


Tabel 34 Penilaian aspek fungsi kontrol kelembaban udara di Taman Tangkuban Perahu (lanjutan)

\begin{tabular}{llcccccc}
\hline & \multicolumn{9}{c}{ Kriteria Fungsi Kontrol } \\
Nama Ilmiah & Nama Lokal & \multicolumn{3}{c}{ Kelembaban Udara } & Skor & Kategori \\
& & K1 & K2 & K3 & K4 & & \\
\hline Samanea saman & Trembesi & 1 & 1 & 3 & 4 & $56 \%$ & Sedang \\
Swietenia mahogani & Mahoni & 1 & 2 & 2 & 3 & $50 \%$ & Sedang \\
Tabebuia chrysanta & Tabebuya & 1 & 2 & 3 & 3 & $56 \%$ & Sedang \\
Tamarindus indica & Asam jawa & 1 & 1 & 3 & 4 & $56 \%$ & Sedang \\
\hline
\end{tabular}

Penilaian KPI menunjukkan mayoritas tanaman Taman Tangkuban Perahu berkategori sedang terhadap fungsi kontrol kelembaban udara (Tabel 34). Tanaman dengan kategori baik dan sangat baik dalam fungsi kontrol kelembaban udafa letaknya menyebar, ditanam soliter di dalam taman dan jumlah individu pohon hanya 4 individu. Tanaman kategori baik dan sangat baik juga digunakan sebagai peneduh dan estetika. Pohon Araucaria heterophylla di taman ini masuk dalām kategori sangat baik dengan skor tertinggi di taman untuk fungsi kontrol kelèmbaban yaitu $88 \%$.

๘ Pengukuran kelembaban udara di Taman Tangkuban Perahu dilakukan tiga kali pengulangan yaitu pada hari minggu tanggal 15 Mei 2016, hari selasa tanggal 24 Mei 2016 dan hari sabtu tanggal 25 Juni 2016. Berdasarkan pengamatan, kelembaban udara rata-rata di atas rumput di bawah pohon mempunyai kelembaban tertinggi diantara titik pengukuran lain di dalam taman dangmampu menaikkan kelembaban hingga 6\% dibandingkan dengan kelembaban luae taman. Hasil pengukuran kelembaban di atas perkerasan mempunyai nilai kelembaban terrendah diantara titik pengukuran lain di dalam taman (Lampiran 16)? Tabel 35 adalah rekapitulasi hasil pengukuran kelembaban udara di Taman Tangkuban Perahu.

Tabel 35 Rekapitulasi hasil pengukuran kelembaban udara di Taman Tangkuban Perahu

\begin{tabular}{llccc}
\hline & Waktu & Pagi & Siang & Sore \\
\hline Titik ukur (\%) & & & & 64 \\
Dalam tapak & 1 & 74 & 60 & 60 \\
& 2 & 70 & 58 & 66 \\
Luar tapak & 3 & 75 & 51 & 58 \\
\hline
\end{tabular}

Tabel 36 Penilaian aspek fungsi kontrol kelembaban udara di Taman Mataram

\begin{tabular}{llcccccc}
\hline & & \multicolumn{9}{c}{ Kriteria Fungsi Kontrol } \\
Nama Ilmiah & Nama Lokal & \multicolumn{7}{c}{ Kelembaban Udara } & Skor & Kategori \\
& & K1 & K2 & K3 & K4 & & \\
\hline $\begin{array}{l}\text { Alstonia scholaris } \\
\text { Artocarpus }\end{array}$ & Pulai & 1 & 1 & 3 & 3 & $50 \%$ & Sedang \\
heterophyllus & Nangka & 1 & 1 & 4 & 4 & $63 \%$ & Baik \\
$\begin{array}{l}\text { Caltistemon citrinus } \\
\text { Ficus benjamina }\end{array}$ & Sikat botol & 1 & 4 & 3 & 4 & $75 \%$ & Baik \\
\hline
\end{tabular}




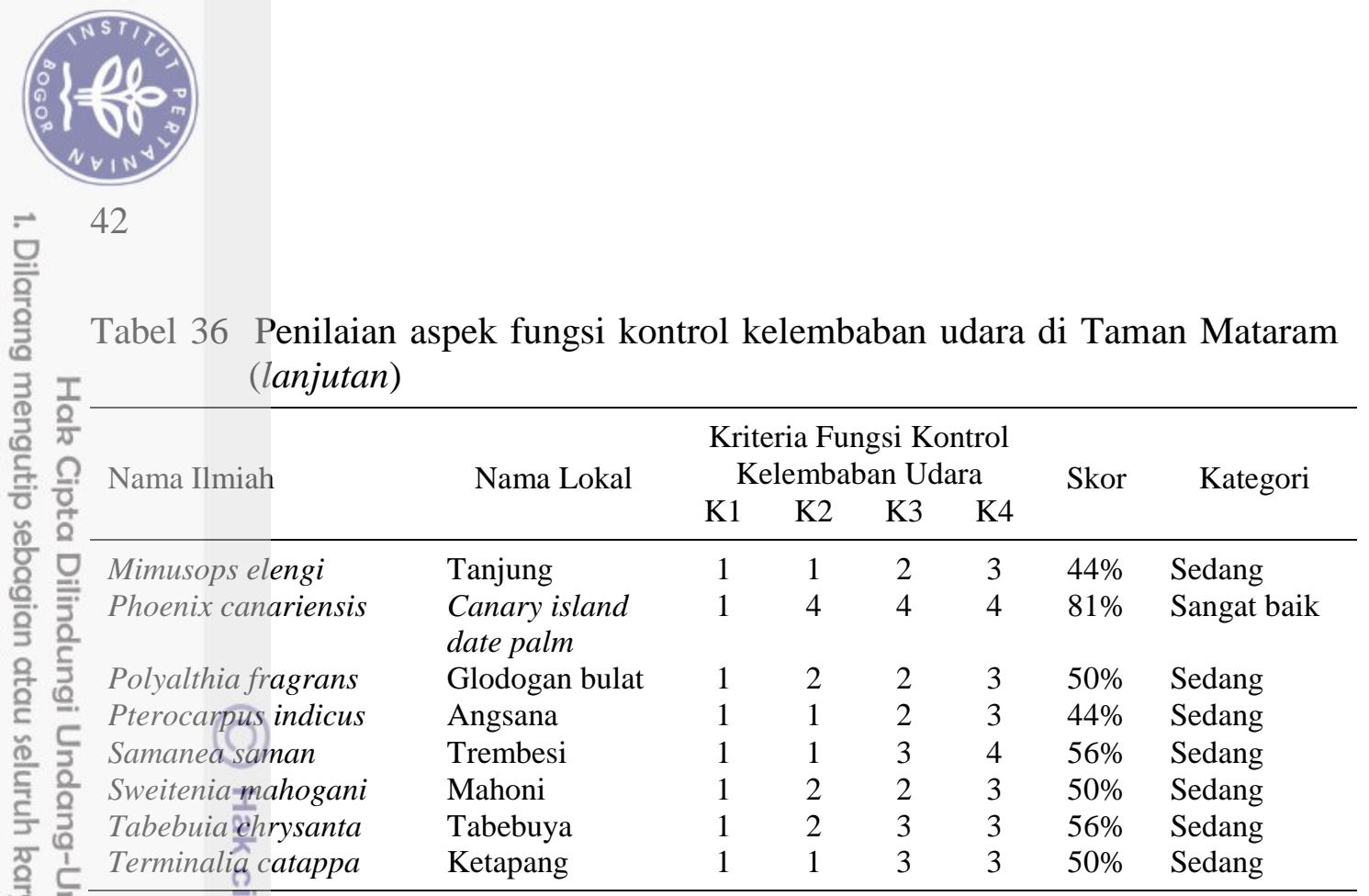

Pênilaian KPI menunjukkan mayoritas tanaman Taman Mataram berkategori sedang terhadap fungsi kontrol kelembaban udara (Tabel 36). Tanaman dengan kategori baik dan sangat baik dalam fungsi kontrol kelembaban udara letaknya menyebar, ditanam soliter di dalam taman. Tanaman kategori baik dan sangat baik juga digunakan sebagai barrier, peneduh dan pengarah. Pohon Phoenix ęanariensis yang dominan di taman ini masuk dalam kategori sangat baik dengan skor tertinggi di taman untuk fungsi kontrol kelembaban yaitu $81 \%$.

Pengukuran kelembaban udara di Taman Mataram dilakukan tiga kali pengulangan yaitu pada hari rabu tanggal 18 Mei 2016, hari minggu tanggal 26 Juni 2016 dan hari senin tanggal 27 Juni 2016. Berdasarkan pengamatan, kelembaban udara rata-rata di atas rumput di bawah pohon mempunyai kelembabän tertinggi diantara titik pengukuran lain di dalam taman dan mampu menaikkan kelembaban hingga 3\% dibandingkan dengan kelembaban luar taman (Lampiran 17). Tabel 37 adalah rekapitulasi hasil pengukuran suhu di Taman Mataram을

Tabel 37 Rekapitulasi hasil pengukuran kelembaban udara di Taman Mataram

\begin{tabular}{lcccc} 
& Waktu & Pagi & Siang & Sore \\
Titik ukur (\%) & & & & 58 \\
Dalam tapak & 1 & 59 & 57 & 57 \\
& 2 & 60 & 58 & 59 \\
Luar tapak & 3 & 60 & 56 & 56 \\
\hline
\end{tabular}

Tabel 38 Presentasi penilaian tanaman fungsi kontrol kelembaban udara

\begin{tabular}{|c|c|c|c|c|}
\hline KategoriW & $\begin{array}{l}\text { Jumlah } \\
\text { jenis }\end{array}$ & $\begin{array}{l}\text { Jumlah } \\
\text { individu }\end{array}$ & $\begin{array}{l}\text { Persentase terhadap total } \\
\text { jenis }(\%)\end{array}$ & $\begin{array}{c}\text { Persentase terhadap total } \\
\text { individu (\%) }\end{array}$ \\
\hline \multicolumn{5}{|c|}{ Taman Ayodya } \\
\hline Sangat baik & 2 & 12 & 11 & 7 \\
\hline Baik & 6 & 100 & 33 & 56 \\
\hline Sedang & 10 & 65 & 56 & 37 \\
\hline Buruk & 0 & 0 & 0 & 0 \\
\hline & & & & Skor $=270$ \\
\hline
\end{tabular}


Tabel 38 Presentasi penilaian tanaman fungsi kontrol kelembaban udara (lanjutan)

\begin{tabular}{|c|c|c|c|c|}
\hline Kategori & $\begin{array}{l}\text { Jumlah } \\
\text { jenis }\end{array}$ & $\begin{array}{l}\text { Jumlah } \\
\text { individu }\end{array}$ & $\begin{array}{l}\text { Persentase terhadap total } \\
\text { jenis }(\%)\end{array}$ & $\begin{array}{l}\text { Persentase terhadap total } \\
\text { individu }(\%)\end{array}$ \\
\hline \multicolumn{5}{|c|}{ Taman Martha Tiahahu } \\
\hline Sangat baik & 1 & 49 & 6 & 30 \\
\hline Baik & 6 & 63 & 38 & 39 \\
\hline Sedang & 9 & 50 & 56 & 31 \\
\hline Buruk & 0 & 0 & 0 & 0 \\
\hline \multirow{2}{*}{\multicolumn{5}{|c|}{ Taman Tangkuban Perahu }} \\
\hline & & & & \\
\hline Sangat baik & 1 & 2 & 8 & 1 \\
\hline Baik & 2 & 2 & 15 & 1 \\
\hline Seđ̄ang & 10 & 155 & 77 & 97 \\
\hline Burruk & 0 & 0 & 0 & 0 \\
\hline क्ष & & & & Skor $=204$ \\
\hline 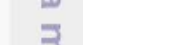 & \multicolumn{4}{|c|}{ Taman Mataram } \\
\hline Sangat baik & 1 & 40 & 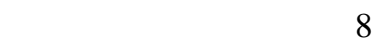 & 27 \\
\hline Baik & 2 & 27 & 17 & 18 \\
\hline Seđ̄āng & 9 & 79 & 75 & 54 \\
\hline Burruk & 0 & 0 & 0 & 0 \\
\hline$\widehat{\equiv}$ & & & & Skor $=273$ \\
\hline
\end{tabular}

Tabel 39 Selisih tingkat kontrol kelembaban udara yang dapat direduksi di taman dengan elemen air

\begin{tabular}{lccc} 
& Taman & Taman Martha Tiahahu \\
\hline Dalam tapak & $\mathrm{P}^{*}$ & 70 & 65 \\
0 & $\mathrm{P} 2$ & 69 & 60 \\
0 & $\mathrm{P} 3$ & 69 & 61 \\
Rata-rata & & 69 & 62 \\
Luar tapak & 64 & 60 \\
Selisih & 5 & 2 & 2 \\
\hline
\end{tabular}

* P1, P2, dan P3 merupakan waktu pengambilan data dari 72 titik di dalam taman

Tabel 40 Selisih tingkat kontrol kelembaban udara yang dapat direduksi di taman tanpa elemen air

\begin{tabular}{lccc}
\hline & Taman & Taman Mataram \\
\hline Titik ukur (\%) & & & \\
\hline Dalam tapak & $\mathrm{P}^{*}$ & 73 & 60 \\
& $\mathrm{P} 2$ & 60 & 58 \\
Rata-rata & $\mathrm{P} 3$ & 63 & 58 \\
Luar tapak & & 65 & 58 \\
Selisih & & 4 & 56 \\
\hline
\end{tabular}

* P1, P2, dan P3 merupakan waktu pengambilan data dari 36 titik di dalam taman 


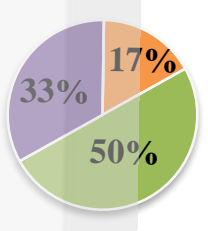

(a)

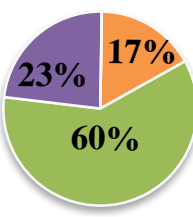

(b)

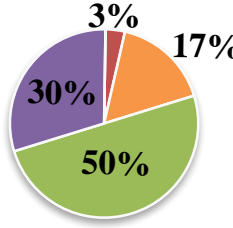

(c)

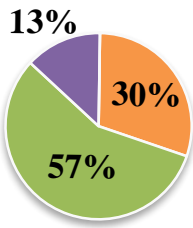

- Sangat kering

Kering

- Sedang

- Lembab

- Sangat lembab

(d)

Gambar 14 Persentase persepsi responden tentang kelembaban udara di (a) Taman Ayodya, (b) Taman Martha Tiahahu, (c) Taman Tangkuban Perahu dan (d) Taman Mataram

Hasil penilaian keseluruhan menunjukkan taman dengan nilai fungsi kontrol kellembaban udara terbaik adalah Taman Martha Tiahahu (Tabel 38). Hasil tersebut tidak sejalan dengan pengukuran tingkat kontrol kelembaban udara di lapang (Tabel 39 dan 40) namun sejalan dengan persepsi responden yaitu Taman Ayodya. Kelembaban udara di Taman Ayodya sedikit banyak dipengaruhi adanya elemen air berupa danau buatan yang berada di tengah taman. Taman Tangkuban Perahu m̄erupakan taman yang mempunyai kelembaban tertinggi jika dibandingkan dengan Taman Mataram karena Taman Tangkuban Perahu memiliki lebih banyak pohon peneduh yang ditanam rapat sehingga cahaya matarahi tidak banyak masuk ke dalam taman dan sifat tanah yang liat juga membuat taman ini semakin Fembab.

\subsubsection{Fungsi penahan angin}

Tăaman dapat mengurangi kecepatan angin serta memanipulasi pergerakan angin sehingga memberi perlindungan pada ruang di dalamnya. Komposisi tanaman yang berbeda ketinggian mampu mengurangi kecepatan angin sekitar 40-50\% (Carpenter et al., 1975). Beberapa kriteria tanaman yang digunaka sebagai penahan angin antara lain:

K1 = Dau tidak mudah gugur (Dahlan 1992)

K2 = Massa daun rapat (DPU Dirjen Bina Marga 1996)

K3 = Tanaman tinggi (Carpenter et al. 1975)

K4 = Daun tebal (DPU Dirjen Bina Marga 1996)

Penilaian terhadap fungsi penahan angin berdasarkan keempat kriteria tersebut pada masing-masing taman diuraikan ke dalam Tabel 41-44.

Tabel 41 Penilaian aspek fungsi penahan angin di Taman Ayodya

\begin{tabular}{llcccccc} 
& & \multicolumn{3}{c}{ Kriteria Fungsi } \\
Nama Ilmiah & Nama Lokal & \multicolumn{3}{c}{ Penahan Angin } & Skor & Kategori \\
& & K1 & K2 & K3 & K4 & & \\
\hline $\begin{array}{l}\text { Agathis dammara } \\
\text { Araucariaheterophylla }\end{array}$ & Damar & 4 & 4 & 2 & 3 & $81 \%$ & Sangat baik \\
$\begin{array}{l}\text { Cemara norflok } \\
\text { Bismarckia nobilis }\end{array}$ & 3 & 4 & 4 & 4 & $94 \%$ & Sangat baik \\
Borassusflabellifer & Bismarck palm & 3 & 4 & 1 & 3 & $69 \%$ & Baik \\
\hline & Lontar & 4 & 2 & 2 & 2 & $63 \%$ & Baik \\
\hline
\end{tabular}


Tabel 41 Penilaian aspek fungsi penahan angin di Taman Ayodya (lanjutan)

\begin{tabular}{|c|c|c|c|c|c|c|c|}
\hline \multirow{2}{*}{ Nama Ilmiah } & \multirow{2}{*}{ Nama Lokal } & \multicolumn{4}{|c|}{$\begin{array}{l}\text { Kriteria Fungsi } \\
\text { Penahan Angin }\end{array}$} & \multirow{2}{*}{ Skor } & \multirow{2}{*}{ Kategori } \\
\hline & & $\mathrm{K} 1$ & $\mathrm{~K} 2$ & $\mathrm{~K} 3$ & $\mathrm{~K} 4$ & & \\
\hline Bucida molineti & $\begin{array}{l}\text { Ketapang daun } \\
\text { kecil }\end{array}$ & 4 & 4 & 2 & 1 & $69 \%$ & Baik \\
\hline Callistemon citrinus & Sikat botol & 3 & 4 & 3 & 2 & $75 \%$ & Baik \\
\hline $\begin{array}{l}\text { Chrysallidocarpus } \\
\text { lucubensis }\end{array}$ & Palem kuning & 3 & 4 & 2 & 2 & $69 \%$ & Baik \\
\hline Cocos nucifera & Kelapa & 3 & 3 & 2 & 2 & $63 \%$ & Baik \\
\hline Cyrtostachis renda & Palem merah & 3 & 3 & 3 & 2 & $69 \%$ & Baik \\
\hline Ficus benjamina & Beringin & 4 & 4 & 4 & 3 & $94 \%$ & Sangat baik \\
\hline Mimusoph elengi & Tanjung & 3 & 3 & 3 & 2 & $69 \%$ & Baik \\
\hline Phoenix canariensis & $\begin{array}{l}\text { Canary island } \\
\text { date palm }\end{array}$ & 4 & 3 & 4 & 3 & $88 \%$ & Sangat baik \\
\hline Plumeria rubra & Kamboja & 3 & 2 & 2 & 2 & $56 \%$ & Sedang \\
\hline Potyalthia longifolia & Glodogan tiang & 4 & 3 & 4 & 1 & $75 \%$ & Baik \\
\hline Pterocarpus indicus & Angsana & 4 & 3 & 2 & 1 & $63 \%$ & Baik \\
\hline Samanea saman & Trembesi & 4 & 2 & 2 & 1 & $56 \%$ & Sedang \\
\hline Tā̄ebuia chrysanta & Tabebuya & 3 & 3 & 3 & 2 & $69 \%$ & Baik \\
\hline 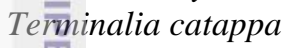 & Ketapang & 4 & 4 & 2 & 3 & $81 \%$ & Sangat baik \\
\hline
\end{tabular}

Penilaian KPI menunjukkan mayoritas tanaman Taman Ayodya berkategori baik terhadap fungsi penahan angin (Tabel 41). Tanaman dengan kategori baik dan sangat baik dalam fungsi penahan angin letaknya menyebar, ditanam soliter di dalam taman. Tanaman kategori baik dan sangat baik juga digunakan sebagai barrier, peneduh dan pengarah. Pohon Ficus benjamina yang berāda di sebelah tenggara taman ini masuk dalam kategori sangat baik dengan skors tertinggi di taman untuk fungsi penahan angin yaitu $94 \%$.

\begin{tabular}{|c|c|c|c|c|c|c|c|}
\hline \multirow{2}{*}{$\begin{array}{c}7 \\
\text { Nama Ilmiah }\end{array}$} & \multirow[b]{2}{*}{ Nama Lokal } & \multicolumn{4}{|c|}{$\begin{array}{l}\text { Kriteria Fungsi } \\
\text { Penah Angin }\end{array}$} & \multirow{2}{*}{ Skor } & \multirow{2}{*}{ Kategori } \\
\hline & & $\mathrm{K} 1$ & $\begin{aligned} \text { enah } \\
\mathrm{K} 2\end{aligned}$ & $\begin{array}{l}\text { Ang } \\
\text { K3 }\end{array}$ & $\mathrm{K} 4$ & & \\
\hline Averrhoa carambola & Belimbing & 3 & 2 & 2 & 1 & $50 \%$ & Sedang \\
\hline Bismarckia nobilis & Bismarck palm & 3 & 4 & 1 & 3 & $69 \%$ & Baik \\
\hline $\begin{array}{l}\text { Chrysalidocarpus } \\
\text { lutescens }\end{array}$ & Palem kuning & 3 & 4 & 2 & 2 & $69 \%$ & Baik \\
\hline Ficus lyrata & Biola cantik & 4 & 2 & 3 & 3 & $75 \%$ & Baik \\
\hline Lagerstromia speciosa & Bungur & 4 & 3 & 3 & 2 & $75 \%$ & Baik \\
\hline Mangifera indica & Mangga & 3 & 3 & 4 & 3 & $81 \%$ & Sangat baik \\
\hline Manilkara kauki & Sawo kecik & 3 & 2 & 3 & 3 & $69 \%$ & Baik \\
\hline $\begin{array}{l}\text { Mascarena } \\
\text { lagenicaulis }\end{array}$ & Palem botol & 2 & 3 & 2 & 3 & $63 \%$ & Baik \\
\hline Pinus merkusii & Pinus & 4 & 1 & 1 & 2 & $50 \%$ & Sedang \\
\hline Polyalthia fragrans & Glodogan bulat & 4 & 3 & 3 & 1 & $69 \%$ & Baik \\
\hline Pterocarpus indicus & Angsana & 4 & 3 & 2 & 1 & $63 \%$ & Baik \\
\hline Roystonea regia & Palem raja & 4 & 3 & 2 & 2 & $69 \%$ & Baik \\
\hline Sweitenia mahogani & Mahoni & 3 & 3 & 3 & 2 & $69 \%$ & Baik \\
\hline Terminalia catappa & Ketapang & 4 & 4 & 2 & 3 & $81 \%$ & Sangat baik \\
\hline
\end{tabular}


Tabel 42 Penilaian aspek fungsi penahan angin di Taman Martha Tiahahu (lanjutan)

\begin{tabular}{|c|c|c|c|c|c|c|c|}
\hline \multirow{2}{*}{ Nama Ilmiah } & \multirow[t]{2}{*}{ Nama Lokal } & \multicolumn{4}{|c|}{$\begin{array}{l}\text { Kriteria Fungsi } \\
\text { Penahan Angin }\end{array}$} & \multirow[t]{2}{*}{ Skor } & \multirow[t]{2}{*}{ Kategori } \\
\hline & & K1 & K2 & $\mathrm{K} 3$ & K4 & & \\
\hline Veitchia merilii & Palem putri & 3 & 4 & 2 & 2 & $69 \%$ & Baik \\
\hline Wodyetia bifurcata & $\begin{array}{l}\text { Palem ekor } \\
\text { tupai }\end{array}$ & 3 & 4 & 2 & 2 & $75 \%$ & Baik \\
\hline
\end{tabular}

Penilaian KPI menunjukkan 94\% tanaman Taman Martha Tiahahu berkategori baik sampai sangat baik terhadap fungsi penahan angin (Tabel 42). Tanaman Idengan kategori baik dan sangat baik dalam fungsi penahan angin letaknya menyebar, ditanam soliter dan berkelompok di taman. Tanaman kategori baik dan-sangat baik juga digunakan sebagai barrier, peneduh dan pengarah. Pohon Mangifera indica dan Terminalia catappa masuk dalam kategori sangat baik dengan skor tertinggi di taman untuk fungsi penahan angin masing-masing yaitu $81 \%$

Tabel $\overline{\overline{4}}$ 移 Penilaian aspek fungsi penahan angin di Taman Tangkuban Perahu

\begin{tabular}{|c|c|c|c|c|c|c|c|}
\hline \multirow{2}{*}{ Nama Ilmilah } & \multirow{2}{*}{ Nama Lokal } & \multicolumn{4}{|c|}{$\begin{array}{l}\text { Kriteria Fungsi } \\
\text { Penahan Angin }\end{array}$} & \multirow{2}{*}{ Skor } & \multirow{2}{*}{ Kategori } \\
\hline & & K1 & K2 & K3 & K4 & & \\
\hline Araucariatheterophylla & Cemara norflok & 3 & 4 & 4 & 4 & $94 \%$ & Sangat baik \\
\hline Artocarpus communis & Sukun & 4 & 3 & 2 & 2 & $69 \%$ & Baik \\
\hline $\begin{array}{l}\text { Artocarpus } \\
\text { heterophy } \overline{\text { tu}}\end{array}$ & Nangka & 4 & 1 & 2 & 2 & $56 \%$ & Sedang \\
\hline Butia captitata & Jelly palm & 4 & 3 & 4 & 3 & $75 \%$ & Baik \\
\hline Mangiferaindica & Mangga & 3 & 3 & 4 & 3 & $81 \%$ & Sangat baik \\
\hline Manglietia glauca & Manglid & 4 & 4 & 3 & 3 & $88 \%$ & Sangat baik \\
\hline Persea americana & Alpukat & 3 & 2 & 4 & 3 & $75 \%$ & Baik \\
\hline Prunus avium & Ceri & 3 & 2 & 3 & 1 & $56 \%$ & Sedang \\
\hline Pterocarpus indicus & Angsana & 4 & 3 & 2 & 1 & $63 \%$ & Baik \\
\hline Samanea saman & Trembesi & 4 & 2 & 2 & 1 & $56 \%$ & Sedang \\
\hline Swietenia mahogani & Mahoni & 3 & 3 & 3 & 2 & $69 \%$ & Baik \\
\hline Tabebuia chrysanta & Tabebuya & 3 & 3 & 3 & 2 & $69 \%$ & Baik \\
\hline Tamarindus indica & Asam jawa & 4 & 2 & 2 & 1 & $56 \%$ & Sedang \\
\hline
\end{tabular}

Penilaian KPI menunjukkan mayoritas tanaman Taman Tangkuban Perahu berkategori baik sampai sangat baik terhadap fungsi penahan angin (Tabel 43). Tanaman dengan kategori baik dan sangat baik dalam fungsi penahan angin letaknya menyebar, ditanam soliter dan berkelompok di taman. Tanaman kategori baik dan sangat baik juga digunakan sebagai peneduh dan pengarah. Pohon Mangifera indica yang dominan di taman ini masuk dalam kategori sangat baik dengan Skor $81 \%$. Selain itu, pohon Araucaria heterophylla dan Manglietia glauca juga termasuk dalam kategori sangat baik dalam fungsi penahan angin dengan skor masing-masing $94 \%$ dan $88 \%$. 
Tabel 44 Penilaian aspek fungsi penahan angin di Taman Mataram

\begin{tabular}{|c|c|c|c|c|c|c|c|}
\hline \multirow[t]{2}{*}{ Nama Ilmiah } & \multirow[t]{2}{*}{ Nama Lokal } & & \multicolumn{3}{|c|}{ Kriteria Fungsi } & \multirow[t]{2}{*}{ Skor } & \multirow[t]{2}{*}{ Kategori } \\
\hline & & $\mathrm{K} 1$ & $\mathrm{~K} 2$ & $\mathrm{~K} 3$ & $\mathrm{~K} 4$ & & \\
\hline Alstonia scholaris & Pulai & 4 & 4 & 3 & 3 & $88 \%$ & Sangat baik \\
\hline $\begin{array}{l}\text { Artocarpus } \\
\text { heterophyllus }\end{array}$ & Nangka & 4 & 1 & 2 & 2 & $56 \%$ & Sedang \\
\hline Callistemon citrinus & Sikat botol & 3 & 4 & 3 & 2 & $75 \%$ & Baik \\
\hline Ficus benjamina & Beringin & 4 & 4 & 4 & 3 & $94 \%$ & Sangat baik \\
\hline Mimusops elengi & Tanjung & 3 & 3 & 3 & 2 & $69 \%$ & Baik \\
\hline Phoenix canariensis & $\begin{array}{l}\text { Canary island } \\
\text { date palm }\end{array}$ & 4 & 3 & 4 & 3 & $88 \%$ & Sangat baik \\
\hline Potyalthia fragrans & Glodogan bulat & 4 & 3 & 3 & 1 & $69 \%$ & Baik \\
\hline Ptêrocarpus indicus & Angsana & 4 & 3 & 2 & 1 & $63 \%$ & Baik \\
\hline Samanea saman & Trembesi & 4 & 2 & 2 & 1 & $56 \%$ & Sedang \\
\hline Swètenia mahogani & Mahoni & 3 & 3 & 3 & 2 & $69 \%$ & Baik \\
\hline Tab̄ebuia chrysanta & Tabebuya & 3 & 3 & 3 & 2 & $69 \%$ & Baik \\
\hline Terminalia catappa & Ketapang & 4 & 4 & 2 & 3 & $81 \%$ & Sangat baik \\
\hline
\end{tabular}

Penilaian KPI menunjukkan mayoritas tanaman Taman Mataram berkategori baik sampai sangat baik terhadap fungsi penahan angin (Tabel 44). Tanâman dengan kategori baik dan sangat baik dalam fungsi penahan angin letaknya menyebar, ditanam soliter dan berkelompok di taman. Tanaman kategori baik $\vec{k}$ dan sangat baik juga digunakan sebagai peneduh dan pengarah. Pohon Ficus benjamina di taman ini merupakan pohon berkategori sangat baik dengan skor tertinggi yaitu $88 \%$. Pohon berkategori sangat baik juga dimiliki pohon Alstonia schölaris, Phoenix canariensis dan Terminalia catappa yang mempunyai skor diatäs $81 \%$.

Tabel 45 Persentase penilaian tanaman fungsi penahan angin

\begin{tabular}{|c|c|c|c|c|}
\hline Kategori & $\begin{array}{l}\text { Jumlah } \\
\text { jenis }\end{array}$ & $\begin{array}{l}\text { Jumlah } \\
\text { individu }\end{array}$ & $\begin{array}{c}\text { Persentase terhadap total } \\
\text { jenis }(\%)\end{array}$ & $\begin{array}{l}\text { Persentase terhadap total } \\
\text { individu }(\%)\end{array}$ \\
\hline \multicolumn{5}{|c|}{ Taman Ayodya } \\
\hline Sangat baik & 5 & 17 & 28 & 10 \\
\hline Baik & 11 & 152 & 61 & 86 \\
\hline Sedang & 2 & 8 & 11 & 5 \\
\hline Buruk & 0 & 0 & 0 & 0 \\
\hline & & & & Skor $=305$ \\
\hline \multicolumn{5}{|c|}{ Taman Martha Tiahahu } \\
\hline Sangat baik & 2 & 7 & 13 & 4 \\
\hline Baik & 12 & 104 & 75 & 64 \\
\hline Sedang & 2 & 51 & 13 & 31 \\
\hline Buruk & 0 & 0 & 0 & 0 \\
\hline \multirow{2}{*}{\multicolumn{5}{|c|}{ Taman Tangkuban Perahu }} \\
\hline & & & & \\
\hline Sangat baik & 3 & 130 & a & 82 \\
\hline Baik & 6 & 18 & 46 & 11 \\
\hline Sedang & 4 & 11 & 31 & 7 \\
\hline \multirow{2}{*}{ Buruk } & 0 & 0 & 0 & 0 \\
\hline & & & & Skor $=375$ \\
\hline
\end{tabular}


Tabel 45 Persentase penilaian tanaman fungsi penahan angin (lanjutan)

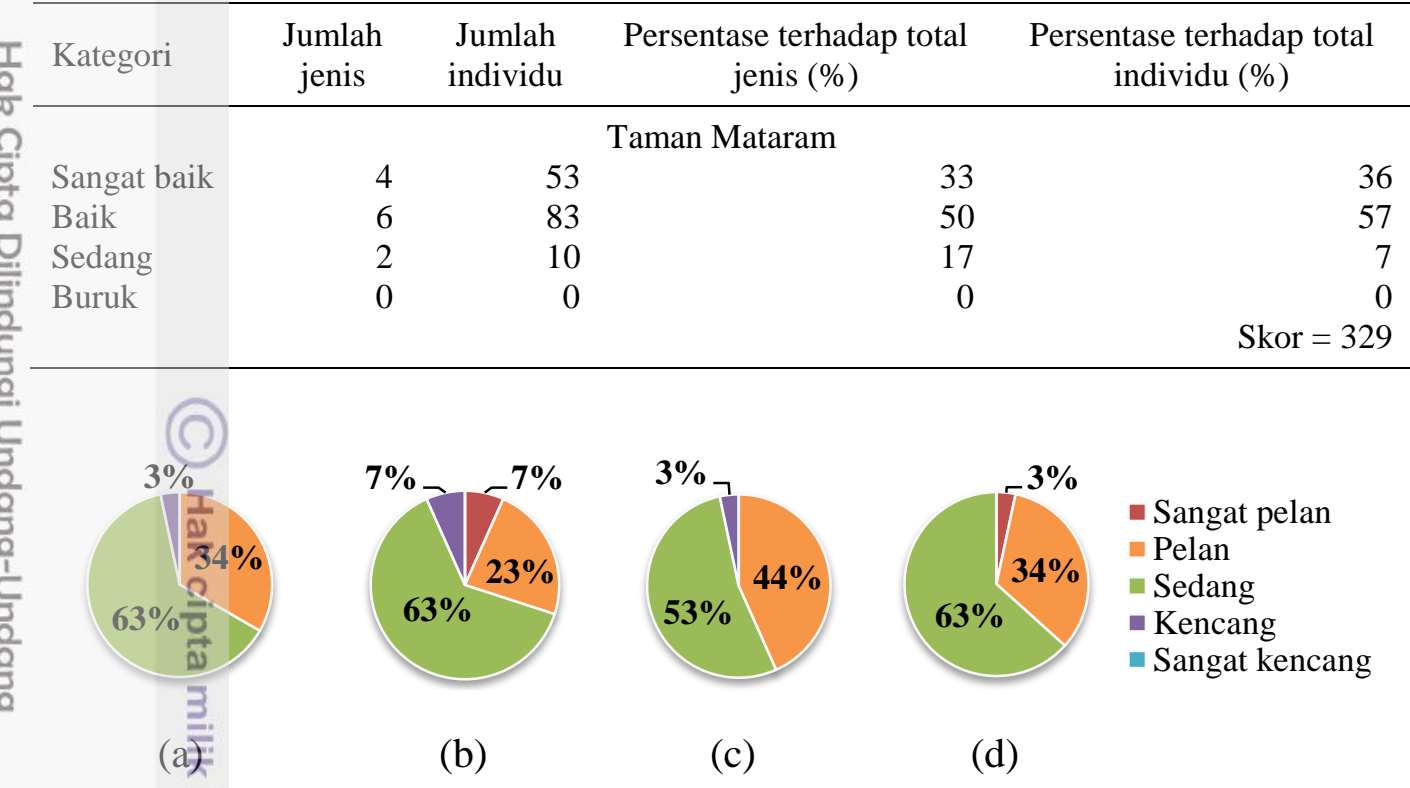

Gambar $\overline{\overline{0}}$ Persentase persepsi responden tentang hembusan angin di (a) Taman Ayodya, (b) Taman Martha Tiahahu, (c) Taman Tangkuban Perahu dan (d) Taman Mataram

Hăsil penilaian keseluruhan menunjukkan taman dengan nilai fungsi penahan āngin terbaik adalah Taman Tangkuban Perahu (Tabel 45). Hasil tersebut sejalan dēngan pengukuran tingkat penahan angin berdasarkan persepsi responden (Gambar 15). Jenis dan letak vegetasi berpengaruh dalam menahan hembusan angin yang kencang.

\subsubsection{Penilaian THI}

THI (Temperature Humidity Index) adalah salah satu metode untuk mengukur pengaruh parameter-parameter iklim terhadap kenyamanan manusia. Berdasarkan Laurie (1986), manusia di daerah tropis akan merasa relatif nyaman jika berada pada suhu udara sekitar $27-28^{\circ} \mathrm{C}$ sedangkan untuk kelembaban udara yang nyaman bagi manusia untuk beraktivitas adalah sekitar 40-75\%. Tabel 46 menunjukkan penilaian THI di Taman Ayodya, Taman Martha Tiahahu, Taman Tangkuban Perahu, dan Taman Mataram.

Tabel 46 Penilaian THI di Taman Ayodya, Taman Martha Tiahahu, Taman Tangkuban Perahu dan Taman Mataram

\begin{tabular}{lcccccc}
\hline & \multicolumn{2}{c}{ T rata-rata $\left({ }^{\circ} \mathrm{C}\right)$} & \multicolumn{2}{c}{ RH rata-rata $(\%)$} & THI & THI \\
\multicolumn{1}{c}{$\begin{array}{c}\text { Dalam } \\
\text { taman }\end{array}$} & $\begin{array}{c}\text { Luar } \\
\text { taman }\end{array}$ & $\begin{array}{c}\text { Dalam } \\
\text { taman }\end{array}$ & $\begin{array}{c}\text { Luar } \\
\text { taman }\end{array}$ & $\begin{array}{c}\text { dalam } \\
\text { taman }\end{array}$ & $\begin{array}{c}\text { luar } \\
\text { taman }\end{array}$ \\
\hline Taman Ayodya & 32.4 & 34,2 & 69 & 64 & 30.4 & 31.7 \\
Taman Martha Tiahahu & 33.0 & 34.3 & 62 & 60 & 30.4 & 31.6 \\
Taman Tangkuban Perahu & 32.9 & 34.1 & 65 & 61 & 30.6 & 31.4 \\
Taman Mataram & 31 & 31.1 & 58 & 56 & 28.4 & 28.4 \\
\hline
\end{tabular}

Suhu udara di Taman Martha Tiahahu adalah yang tertinggi dan Taman Mataram-adalah yang terendah diantara taman lainnya. Perbedaan suhu keempat 
taman masih relatif sama dan suhu udara tersebut kurang nyaman bagi manusia. Sebaliknya, kelembaban udara di empat taman merupakan kondisi nyaman untuk beraktivitas.

Iklim mikro juga dihitung dengan menggunakan formulasi THI. Taman Ayodya memiliki indeks THI sebesar 30.4, Taman Martha Tiahahu sebesar 30.4, Taman tangkuban Perahu sebesar 30.6 dan Taman Mataram sebesar 28.4. Hasil penghitungan THI menunjukan bahwa keempat taman tersebut belum dapat mencapai kenyamanan ideal sesuai dengan pernyataan Laurie (1986). Walau demikian, jika indeks THI dibandingkan dengan kondisi di luar taman, kondisi di dalam taman memiliki nilai index yang lebih rendah. Hal ini menunjukkan bahwa keempat taman mampu mengurangi suhu udara dan meningkatkan kenyamanan.

\subsection{Evaluasi Fungsi Estetika}

Penilaian SBE dengan penyebaran kuesioner dilakukan kepada 30 mahasiswa Arsitektur Lanskap semester IV dan VIII. Hasil penilaian tersebut menghasilkan nilai SBE untuk setiap foto lanskap pada keempat taman yang disajikan dalam bentuk grafik balok nilai SBE untuk masing-masing taman. Hasil fotō lanskap yang dinilai juga akan dibagi dalam 3 kategori, yaitu: kualitas estetika tinggi, sedang dan rendah. Nilai SBE tertinggi menunjukkan lanskap yang secă $\overline{\text { ra }}$ visual dinilai paling indah dan disukai oleh responden, sebaliknya nilai SBE

\subsection{Taman Ayodya}

Foto lanskap pada Taman Ayodya yang dipresentasikan sebanyak 20 buah. Fotē lanskap tersebut mewakili seluruh area di Taman Ayodya karena lokasinya menyebar (Gambar 16). Mayoritas foto lanskap Taman Ayodya berkualitas tinggi danosedang seperti ditunjukkan pada Gambar 17. Penilaian lanskap tertinggi di Taman Ayodya adalah lanskap 10 (SBE 111,27) sedangkan penilaian lanskap terendah di Taman Ayodya adalah lanskap 20 (SBE -131,28)(Gambar 18).

Kategori nilai foto SBE tinggi Taman Ayodya memiliki pola desain organik, dominan elemen lunak seperti air dan tanaman dengan ragam tanaman pohon dan semak. Kategori nilai foto SBE sedang memiliki pola desain organik, adanya elemen keras dan lunak dengan ragam tanaman pohon dan semak. Kategori nilai foto SBE rendah memiliki pola desain geometris, dominan berelemen keras dengan ragam tanaman semak. 
뭉

舟

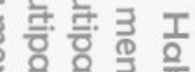

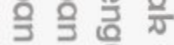

흥흥흠 움

政造

远急长.

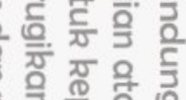

지융

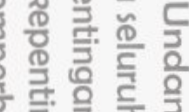

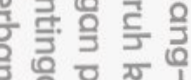

일 옹동

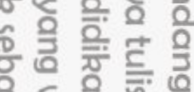

ह้ํํำ

윽일 혹

믈
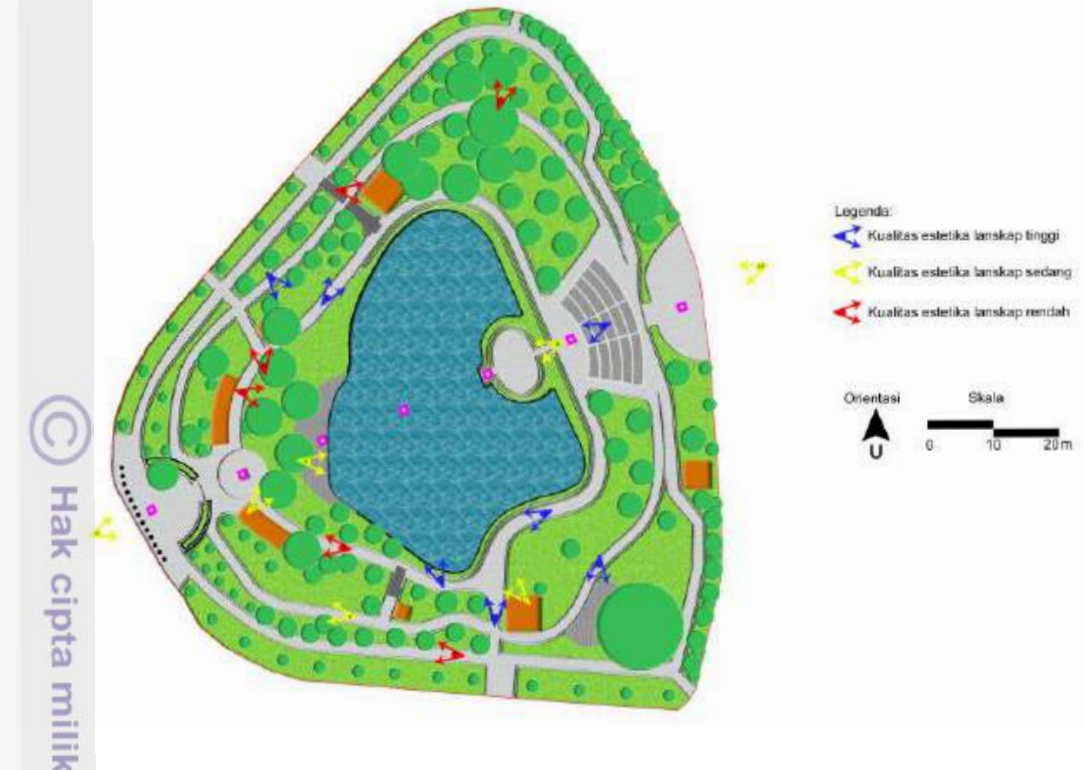

Gambar 16 Sebaran foto lanskap Taman Ayodya dan klasifikasinya

西

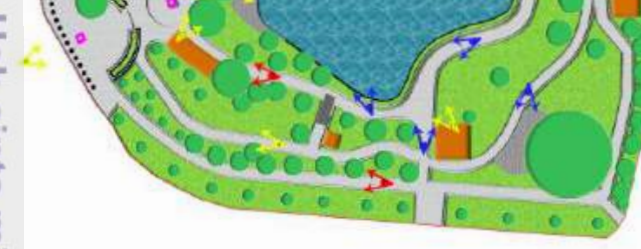

ใิ

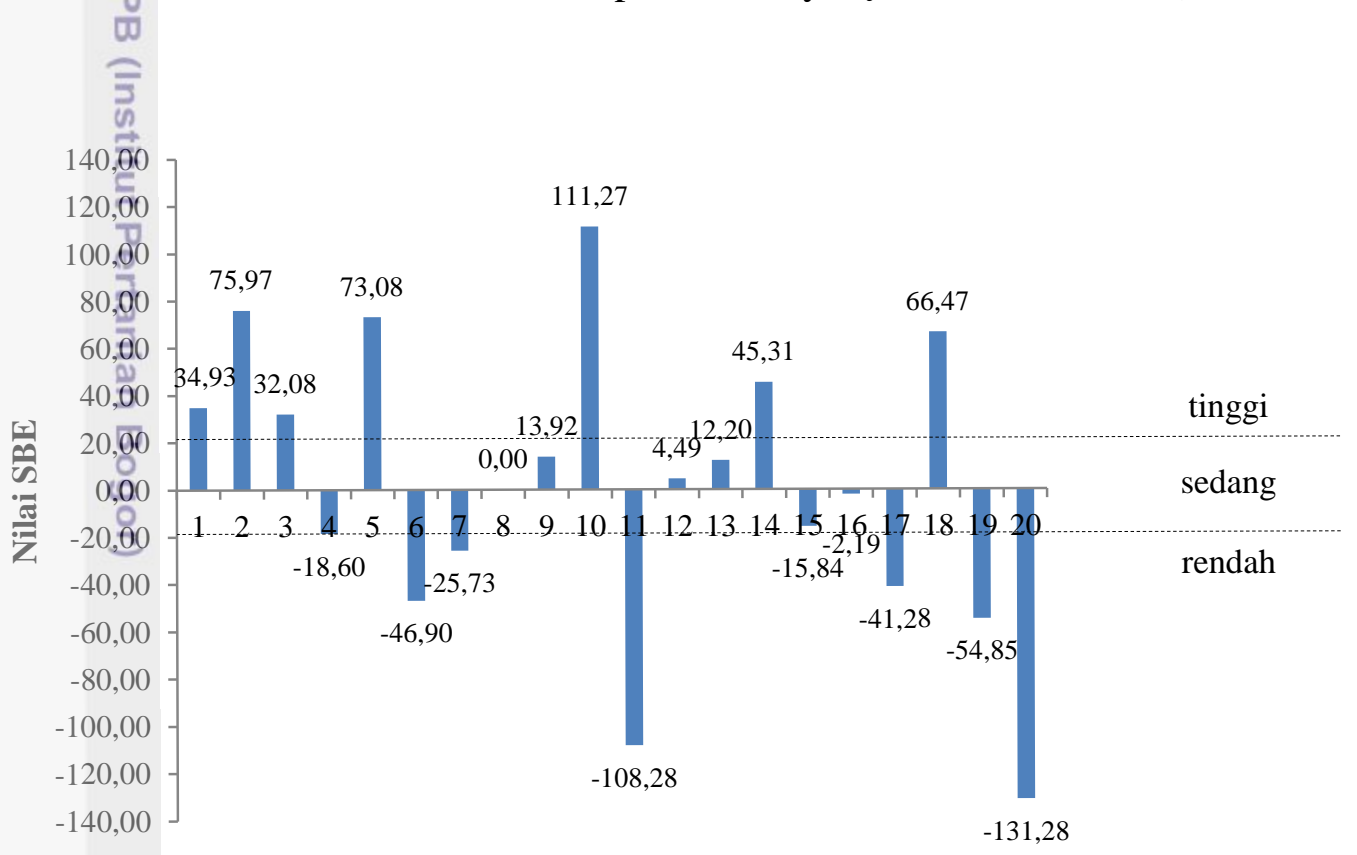

Gambar 17 Nilai Scenic Beauty Estimation(SBE) setiap foto lanskap Taman Ayodya 


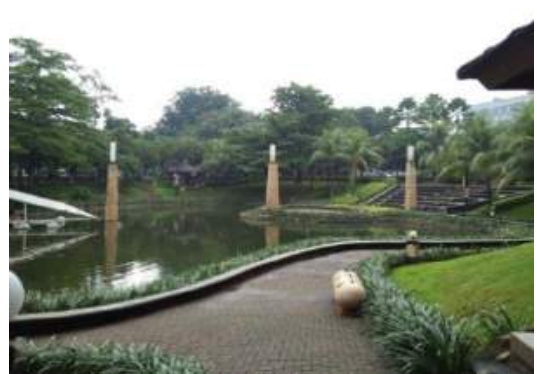

(a)

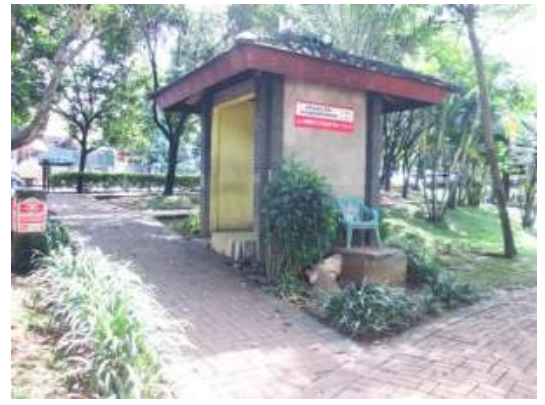

(b)

Gambar 18 (a) Lanskap 10 (nilai SBE tertinggi) dan (b) Lanskap 20 (nilai SBE terendah)

5.3.2 Taman Martha Tiahahu

Foto lanskap pada Taman Martha Tiahahu yang dipresentasikan sebanyak 20 biah. Foto lanskap tersebut mewakili seluruh area di Taman Martha Tiahahu karēna lokasinya menyebar (Gambar 19). Mayoritas foto lanskap Taman Martha Tiahahu berkualitas tinggi seperti ditunjukkan pada Gambar 20. Penilaian lanskap tertinggi di Taman Martha Tiahahu adalah lanskap 6 (SBE 80,63) sedangkan penilaian lanskap terendah di Taman Martha Tiahahu adalah lanskap 11 (SBE 107,02) (Gambar 21).

Kategori nilai foto SBE tinggi Taman Martha Tiahahu memiliki pola desain organik, dominan elemen lunak seperti air dan tanaman dengan ragam tanăman pohon dan lawn. Kategori nilai foto SBE sedang memiliki pola desain orgånik, dominan elemen lunak dengan ragam tanaman pohon. Kategori nilai foto SBE rendah memiliki pola desain organik, dominan berelemen keras dengan ragam tanaman pohon.
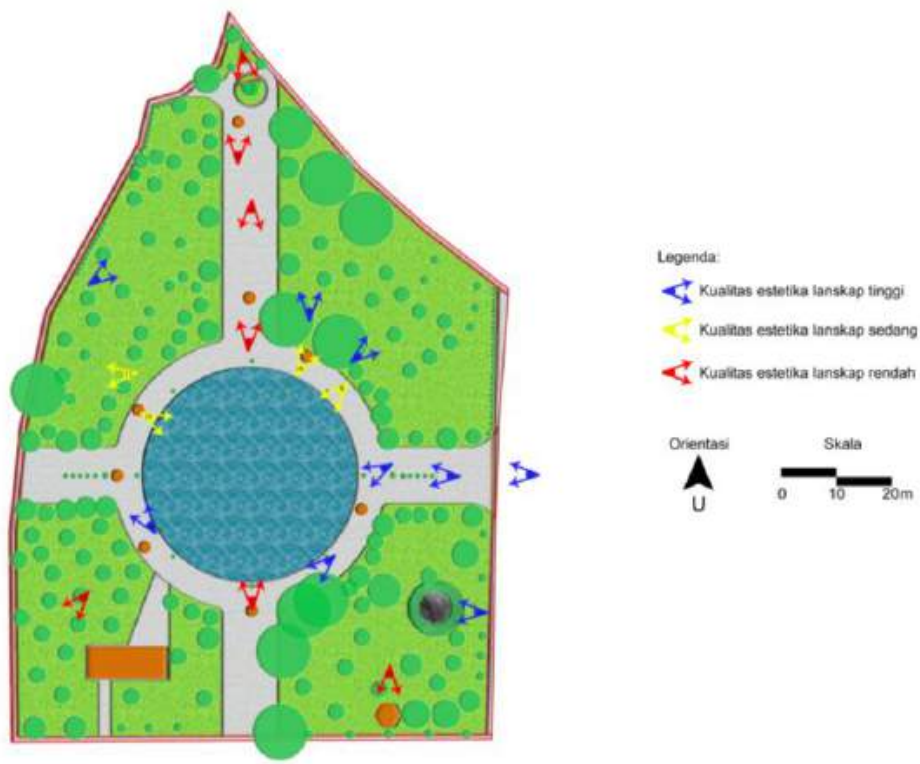

Gambar 19 Sebaran foto lanskap Taman Martha Tiahahu dan klasifikasinya 


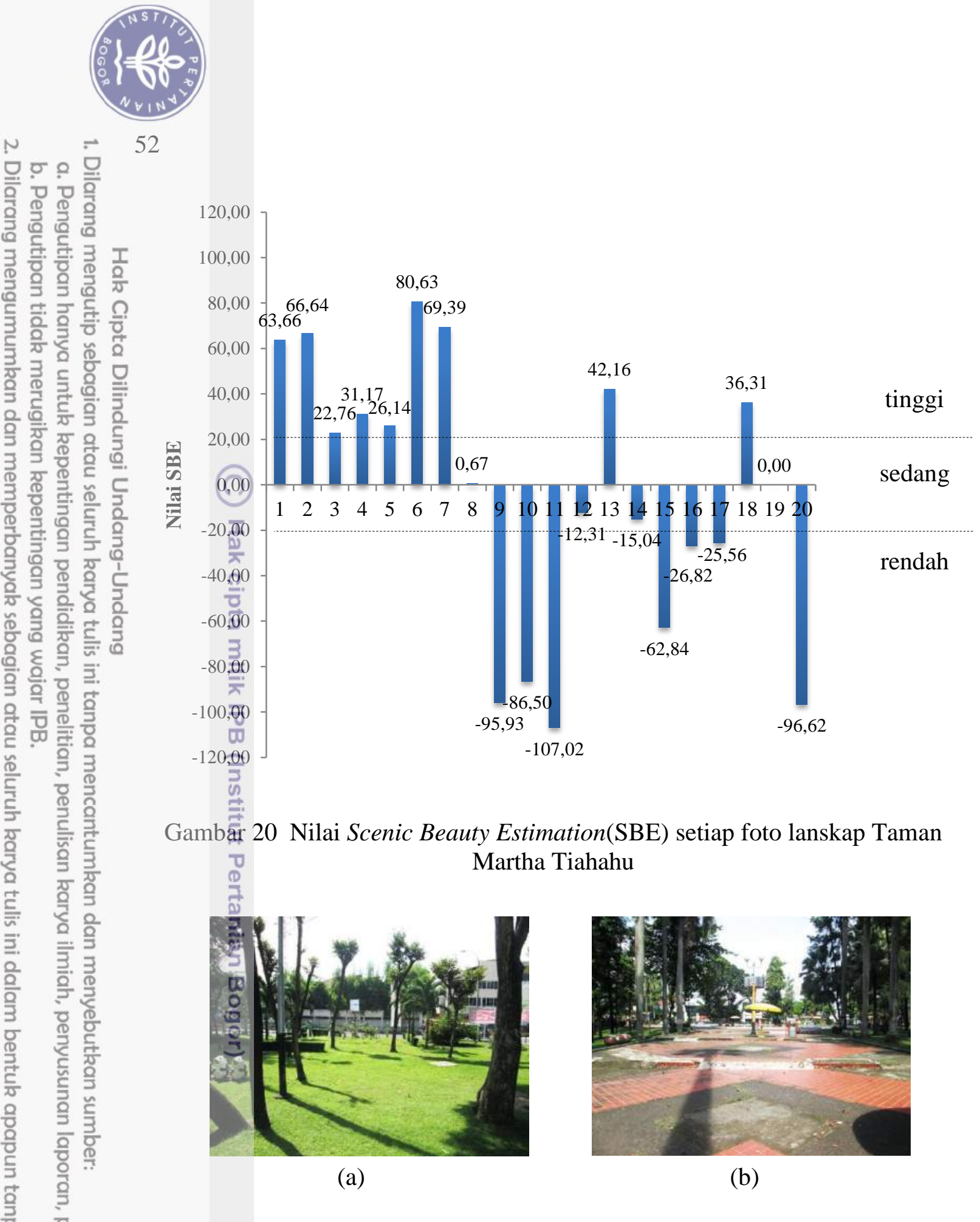

Gambar 21 (a) Lanskap 6 (nilai SBE tertinggi) dan (b) Lanskap 11 (nilai SBE terendah)

\subsubsection{Taman Tangkuban Perahu}

Foto lanskap pada Taman Tangkuban Perahu yang dipresentasikan sebanyak 20 buah. Foto lanskap tersebut mewakili seluruh area di Taman Tangkuban Perahu karena lokasinya menyebar (Gambar 22). Mayoritas foto lanskap Taman Tangkuban Perahu berkualitas sedang seperti ditunjukkan pada Gambar 23. Penilaian lanskap tertinggi di Taman Tangkuban Perahu adalah lanskap 10 (SBE 124,75) sedangkan penilaian lanskap terendah di Taman Tangkuban Perahu adalah lanskap 1 (SBE -145,78) (Gambar 24). 
Kategori nilai foto SBE tinggi Taman Tangkuban Perahu memiliki pola desain organik, dominan elemen lunak seperti air dan tanaman dengan ragam tanaman pohon dan semak. Kategori nilai foto SBE sedang memiliki pola desain organik, dominan elemen lunak dengan ragam tanaman pohon. Kategori nilai foto SBE rendah memiliki pola desain organik, dominan berelemen keras dengan ragam tanaman pohon.

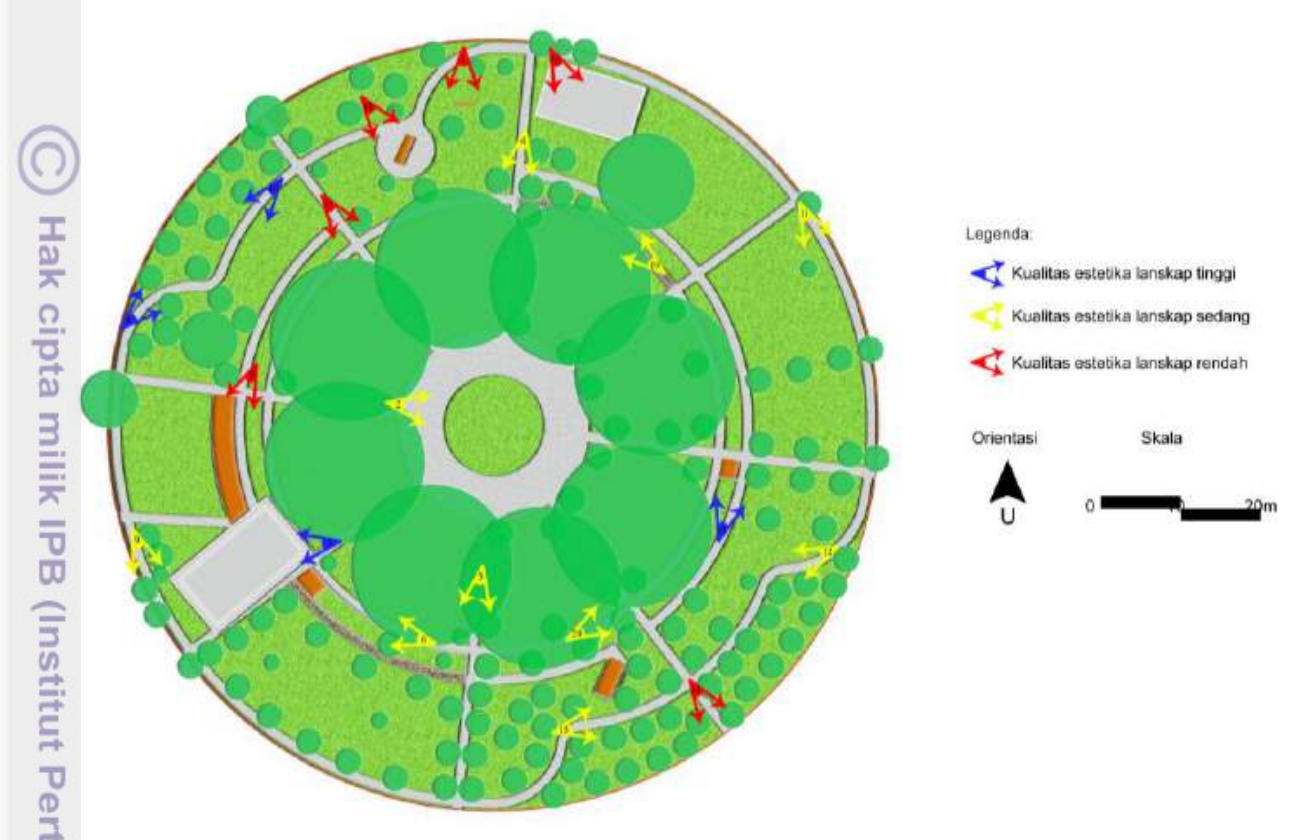

Gambar 22 Sebaran foto lanskap Taman Martha Tiahahu dan klasifikasinya

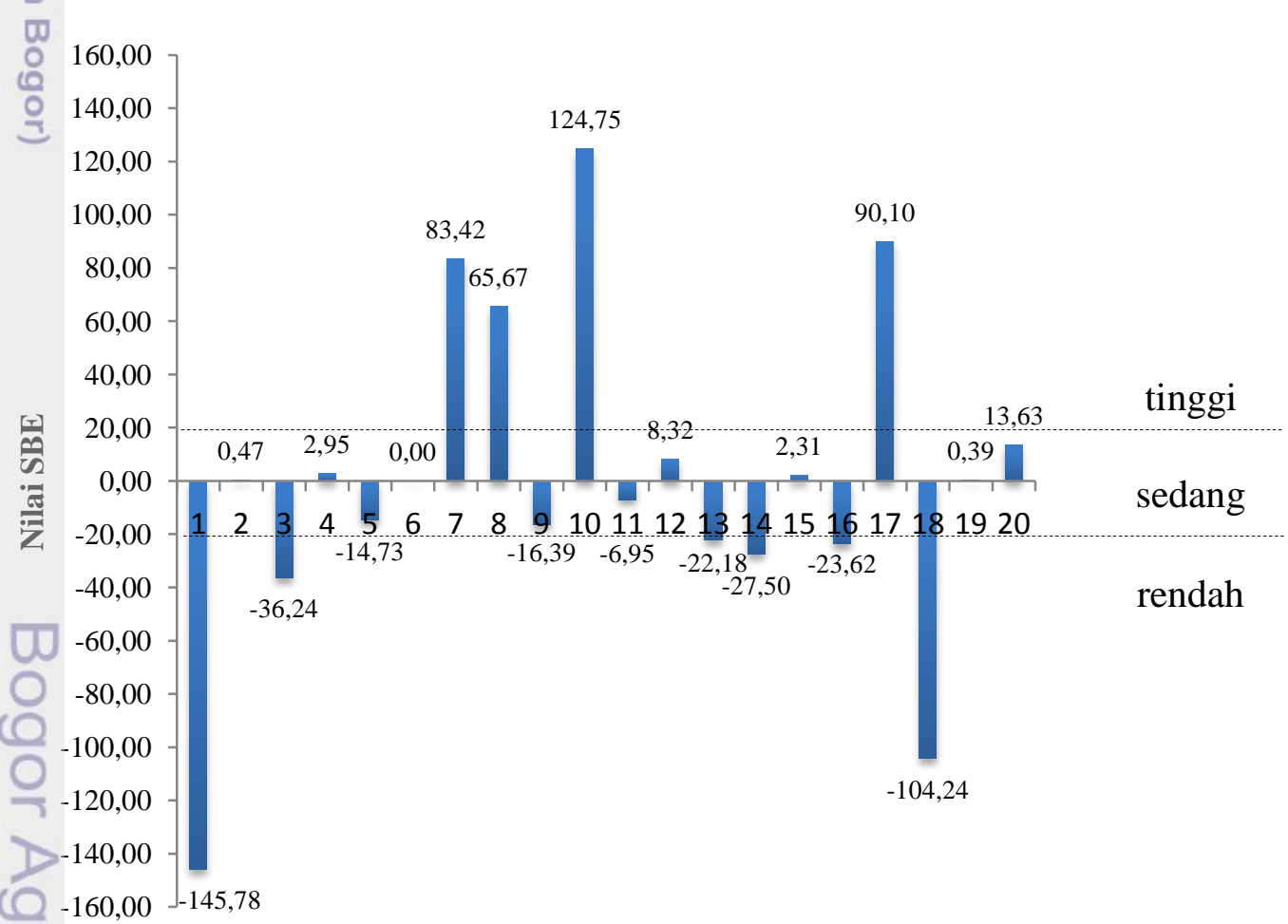

Gambar 23 Nilai Scenic Beauty Estimation(SBE) setiap foto lanskap Taman Tangkuban Perahu 


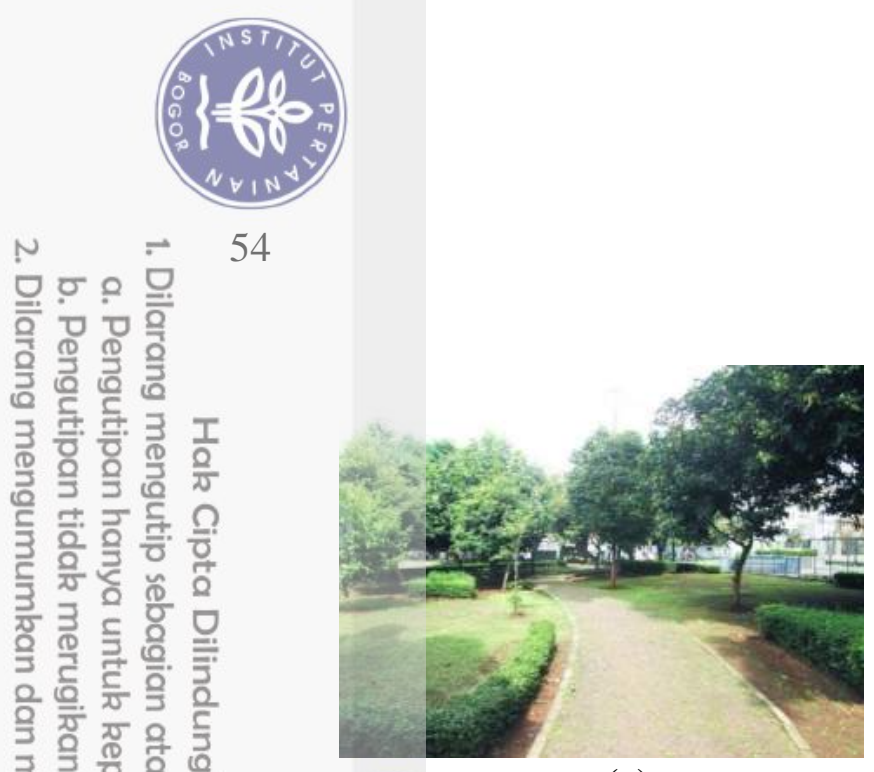

(a)

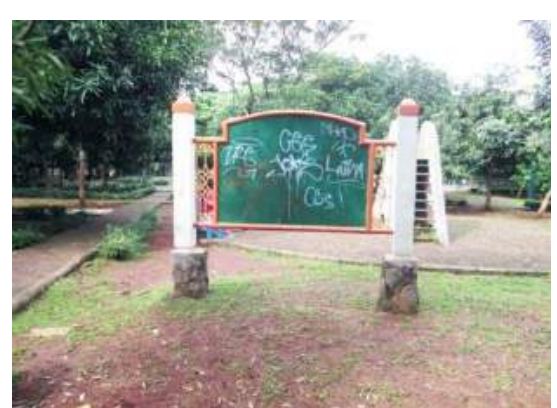

(b)

Gambarn24 (a) Lanskap 10 (nilai SBE tertinggi) dan (b) Lanskap 1 (nilai SBE terendah)

\subsubsection{Taman Mataram}

Föto lanskap pada Taman Mataram yang dipresentasikan sebanyak 20 buah. Foto lanskap tersebut mewakili seluruh area di Taman Mataram karena lokasinyāmenyebar (Gambar 25). Mayoritas foto lanskap Taman Mataram berkualitas sedang seperti ditunjukkan pada Gambar 26. Penilaian lanskap tertinggi di Taman Mataram adalah lanskap 1 (SBE 66,12) sedangkan penilaian lanskap têrendah di Taman Mataram adalah lanskap 17 (SBE -112,82) (Gambar 27).

Kategori nilai foto SBE tinggi Taman Tangkuban Perahu memiliki pola desain organik, dominan elemen lunak seperti air dan tanaman dengan ragam tanaman pohon dan semak. Kategori nilai foto SBE sedang memiliki pola desain organik, đöminan elemen lunak dengan ragam tanaman pohon. Kategori nilai foto SBE renđah memiliki pola desain organik, dominan berelemen keras dengan ragam taraman pohon.
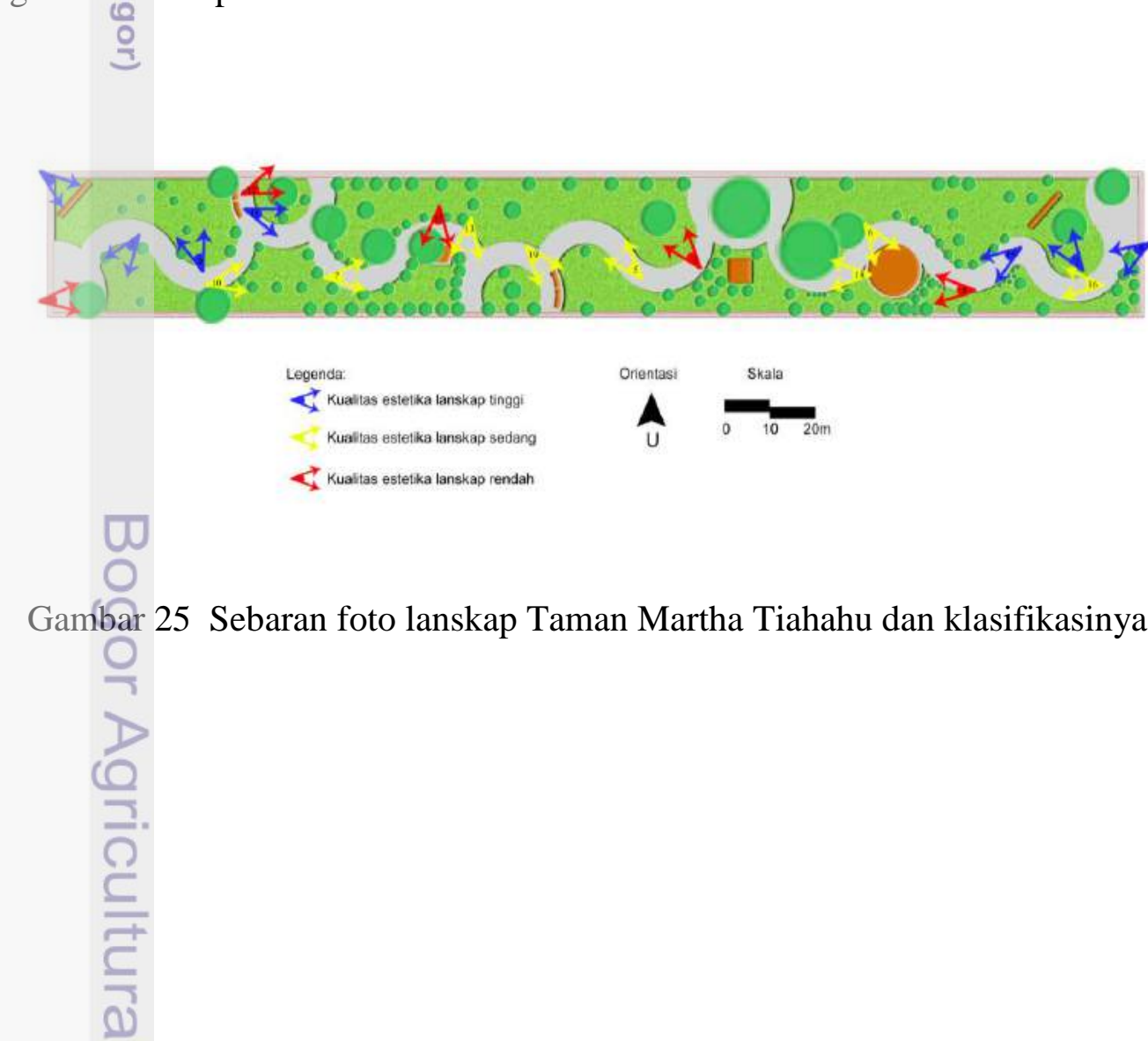

U

Gambar 25 Sebaran foto lanskap Taman Martha Tiahahu dan klasifikasinya 


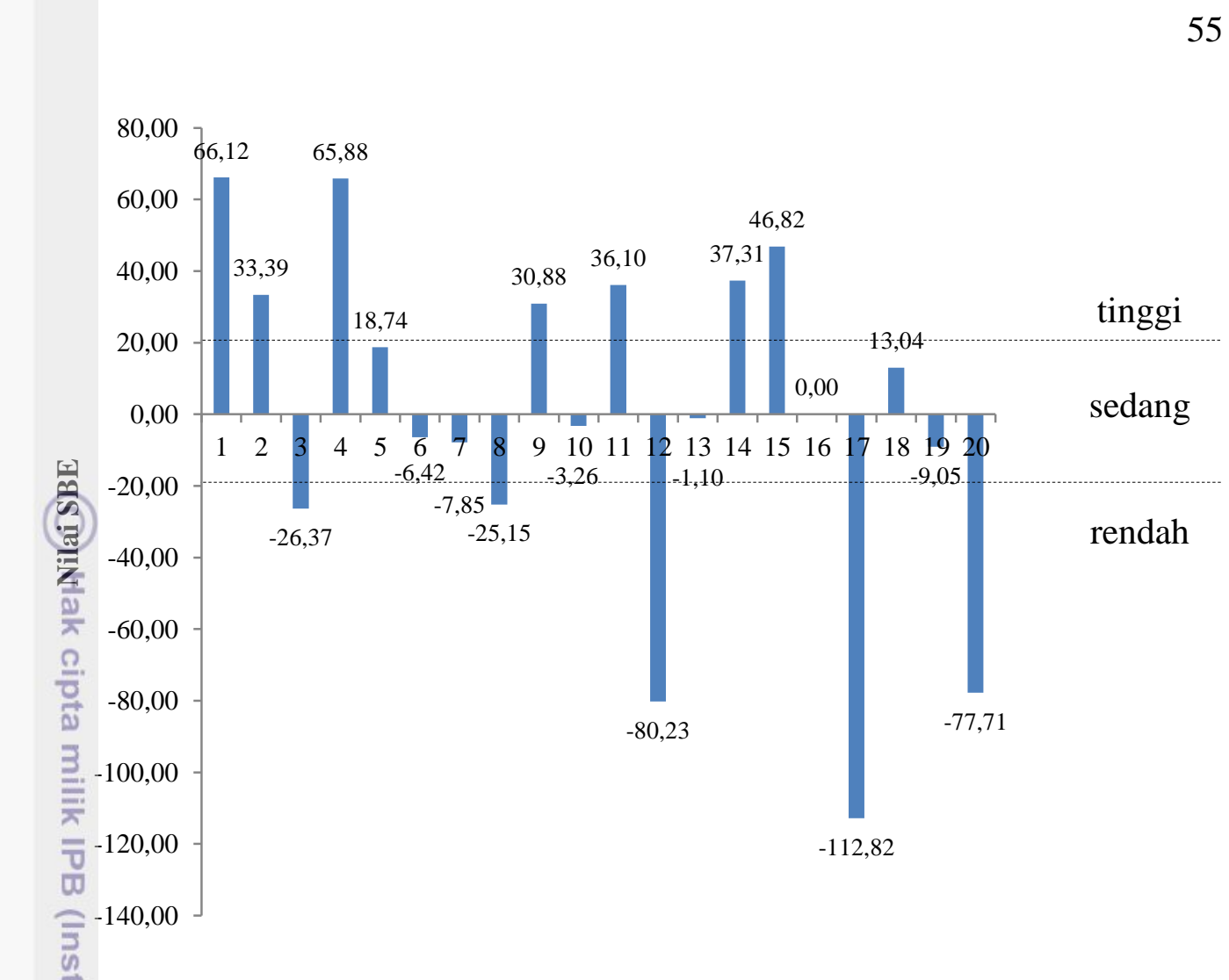

Gam̄bar 26 Nilai Scenic Beauty Estimation(SBE) setiap foto lanskap Taman Mataram

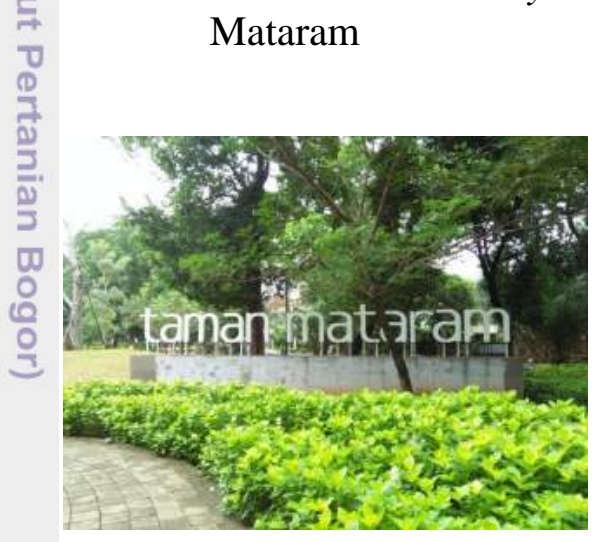

(a)

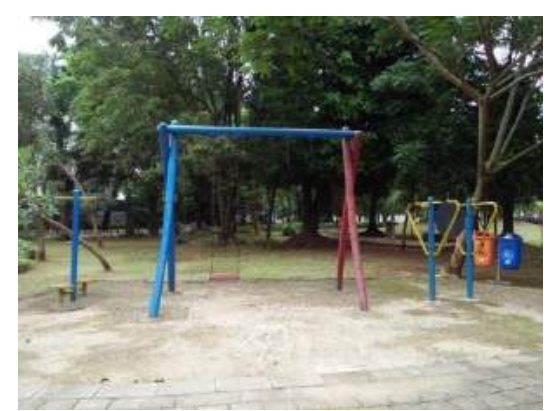

(b)

Gambar 27 (a) Lanskap 1 (nilai SBE tertinggi) dan (b) Lanskap 17 (nilai SBE terendah)

\subsection{Persepsi dan Preferensi Responden}

Penyebaran kuesioner telah dilakukan kepada 120 orang responden (pengunjung taman) dengan bobot tiap taman sebanyak 30 orang responden. Jumlah tersebut diharapkan dapat mewakili seluruh pengunjung di tiap taman. Hasil pengolahan kuesioner, didapat karakteristik dan persepsi responden mengenai estetika dan kenyamanan di tiap taman. Persepsi masyarakat diperlukan datam penelitian ini karena masyarakat sebagai salah satu unsur atau aktor dalam pemeliharaan taman sehingga perlu adanya kesamaan persepsi dalam 
pengembangannya. Masyarakat juga yang secara langsung menggunakan fasilitas yang ada pada taman dan secara tidak langsung ikut berpartisipasi dalam

I mengelola taman.

\subsubsection{Karakteristik Responden}

Karakteristik responden yang diamati dalam penelitian ini terdiri dari jenis kelamin, tempat tinggal, profesi dan tujuan. Pengetahuan terhadap ․ㅡㄹ karakteristik responden dapat digunakan untuk mengetahui preferensi responden mengunjungi taman dan pengetahuan masyarakat tentang keberadaan taman serta - fungsi taman dalam kehidupan masyarakat. Diagram pie pada Gambar 28-31 menunjukkan masing-masing karakteristik responden setiap taman.

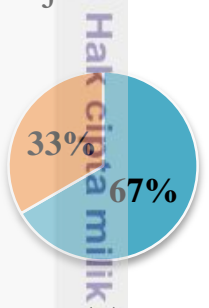

(a)

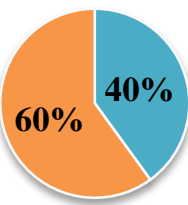

(b)

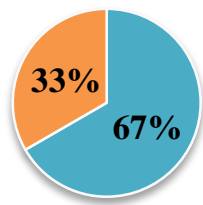

(c)

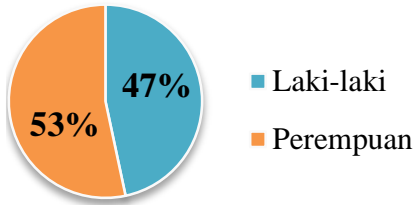

(d)

Gambar 28 Persentase jenis kelamin responden di (a) Taman Ayodya, (b) Taman Martha Tiahahu, (c) Taman Tangkuban Perahu dan (d) Taman Mataram

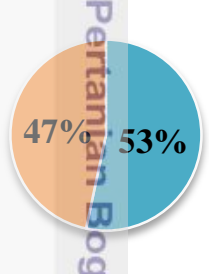

(a)

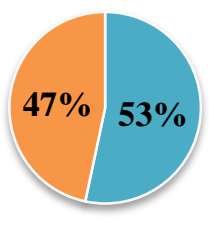

(b)

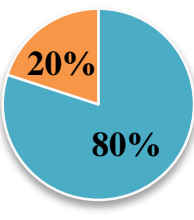

(c)

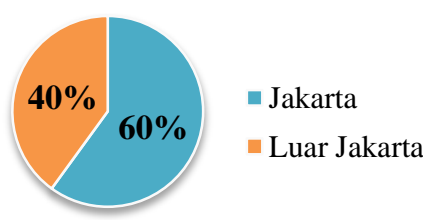

(d)

Gambar 29 Persentase tempat tinggal responden di (a) Taman Ayodya, (b) Taman Martha Tiahahu, (c) Taman Tangkuban Perahu dan (d) Taman Mataram

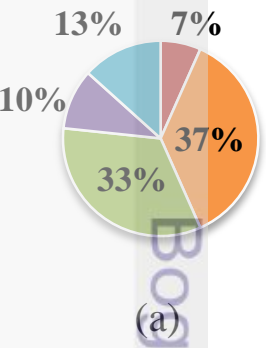

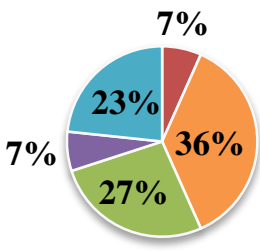

(b)

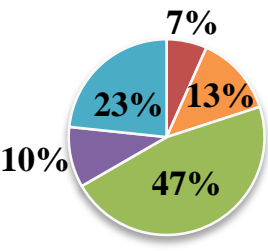

(c)

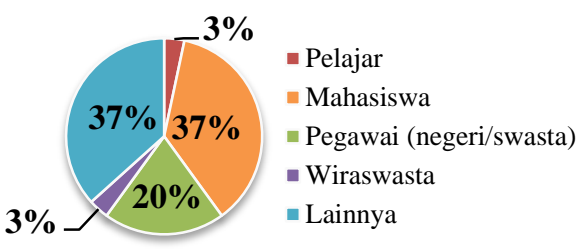

(d)

Gambar 30 Persentase profesi responden di (a) Taman Ayodya, (b) Taman Martha Tiahahu, (c) Taman Tangkuban Perahu dan (d) Taman Mataram 


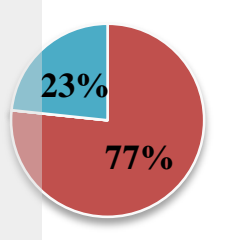

(a)

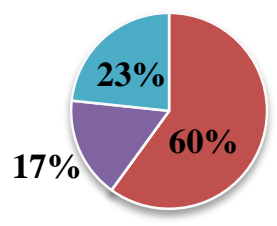

(b)

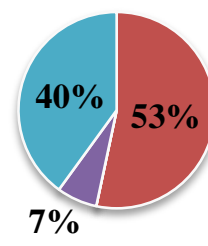

(c)

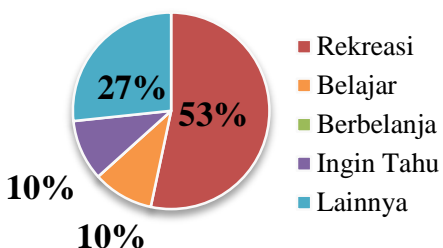

(d)

Gambar 31 Persentase tujuan responden di (a) Taman Ayodya, (b) Taman Martha Tiahahu, (c) Taman Tangkuban Perahu dan (d) Taman Mataram

Persentase pengunjung keempat taman masih seimbang antara perempuan dan laki-laki. Pengunjung taman didominasi masyarakat yang tinggal disekitar tamạn dan berasal dari Jakarta serta berprofesi sebagai pegawai. Mayoritas responden mengunjungi taman untuk rekreasi atau sekedar istirahat.

\subsubsection{Persepsi Responden}

Persepsi responden yang diamati dalam penelitian ini terkait pemandangan di tāman, penataan elemen taman, kenyamanan suhu udara, kebisingan, hembusan angin, kelembaban udara, kebersihan taman dan kesan kolam ditaman. Tiap pertanyaan memiliki lima pilihan dan responden hanya dapat memilih satu jawäban menurut persepsi mereka. Pilihan jawaban meliputi sangat buruk, buruk, sedāng, baik dan sangat baik namun disesuaikan dengan pertanyaan yang diberikan. Diagram pie pada Gambar 32-35 menunjukkan masing-masing persepsi responden setiap taman.

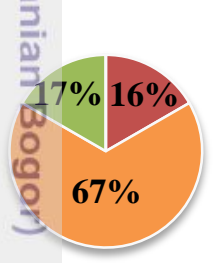

(a)

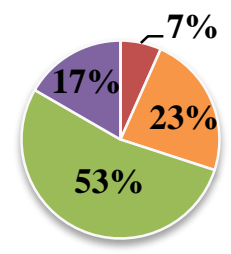

(b)

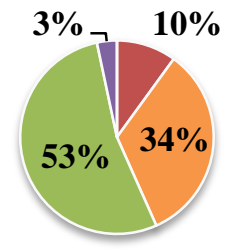

(c)

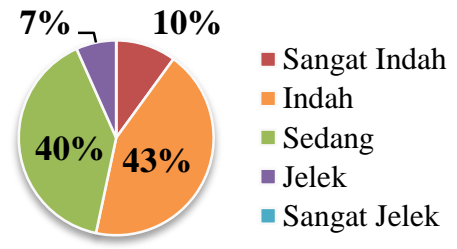

(d)

Gambar 32 Persentase persepsi responden terhadap pemandangan di (a) Taman Ayodya, (b) Taman Martha Tiahahu, (c) Taman Tangkuban Perahu dan (d) Taman Mataram

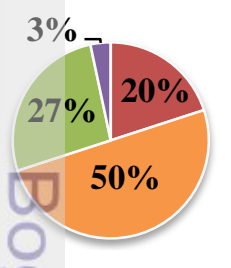

(a)

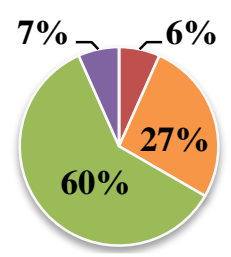

(b)

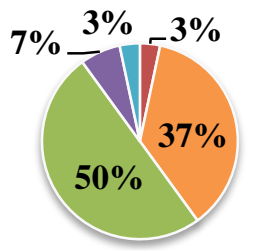

(c)

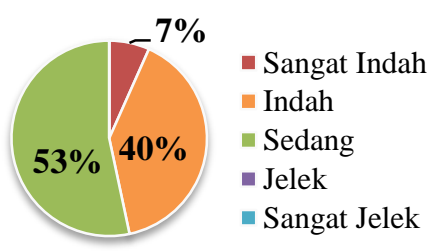

(d)

Gambar 33 Persentase persepsi responden terhadap penataan elemen taman di (a) Taman Ayodya, (b) Taman Martha Tiahahu, (c) Taman Tangkuban Perahu dan (d) Taman Mataram 


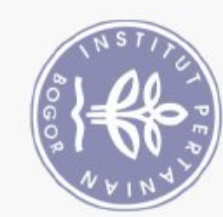

58

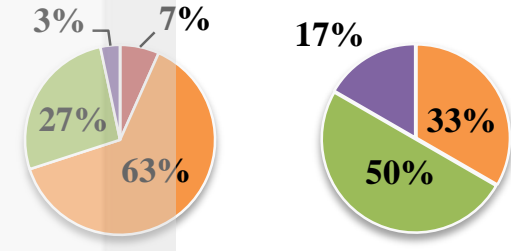

(a)

(b)

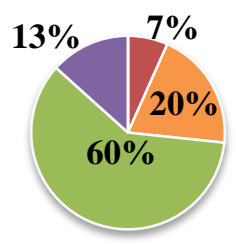

(c)

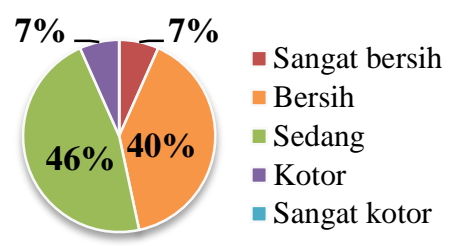

(d)

Gambar 34 Persentase persepsi responden terhadap kebersihan taman di (a) Taman Ayodya, (b) Taman Martha Tiahahu, (c) Taman Tangkuban Perahu dan (d) Taman Mataram

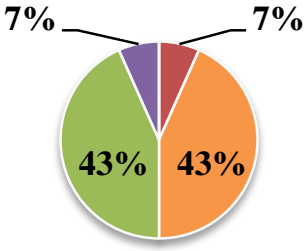

(a)

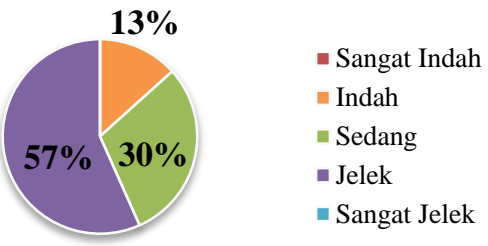

(b)

Gambar 35 Persentase persepsi responden terhadap keindahan kolam di (a) Taman Ayodya dan (b) Taman Martha Tiahahu

Hăsil persepsi masyarakat mengenai keindahan (pemandangan, penataan, dan kebersihan) taman ternyata sejalan dengan hasil evaluasi kualitas estetika menggunakan SBE. Berdasarkan persepsi mengenai pemandangan taman, Taman Ayodya mendapat persepsi yang paling indah, kedua Taman Mataram, ketiga Taman Tangkuban Perahu dan yang terakhir Taman Martha Tiahahu. Penataan elemen dan kebersihan keempat taman mayoritas dinilai sedang oleh responden. Kesan kolam di Taman Ayodya dinilai indah, namun kesan kolam di Taman Martha Tiahahu dinilai jelek karena kurangnya atraksi yang ditampilkan di kolam.

\subsubsection{Preferensi Responden}

Preferensi responden terhadap aktivitas dan fasilitas yang diinginkan menjadi pertimbangan mengenai fungsi taman yang diinginkan oleh pengunjung taman. Hasil kuesioner menunjukkan keinginan responden dengan tersedianya beberapa fasilitas pendukung di taman yang dapat menunjang aktivitas pengunjung (Gambar 36 dan 37). Fasilitas tersebut meliputi tempat duduk, toilet, musala, taman bermain dan lapangan olahraga. Preferensi tersebut untuk mengakomodasi kegiatan yang ingin dilakukan pengunjung seperti duduk-duduk, olahraga, bermain dan fotografi. Adanya tanaman berbunga dan berwarna merupakan keinginan responden untuk menambah keindahan taman karena dapat memberiOkesan menarik dan tidak monoton. Responden juga menginginkan penggunaan tanaman yang bertajuk lebar untuk menambah kesejukan dan kenyamanan di taman. 


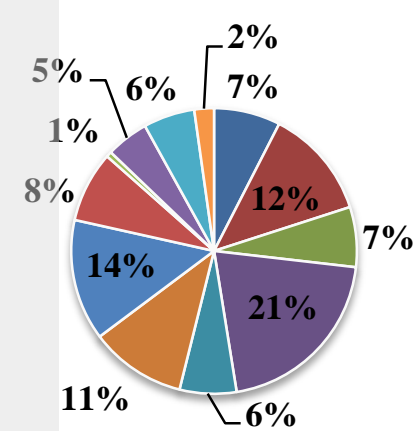

(a)

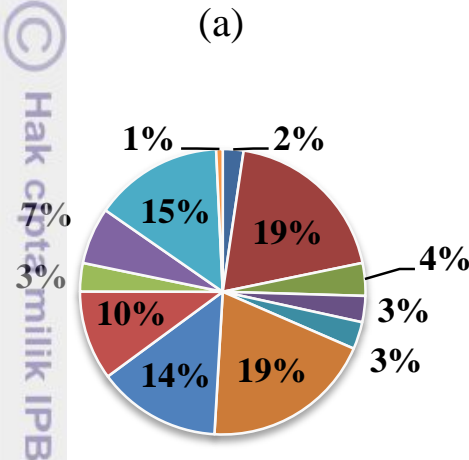

(c)

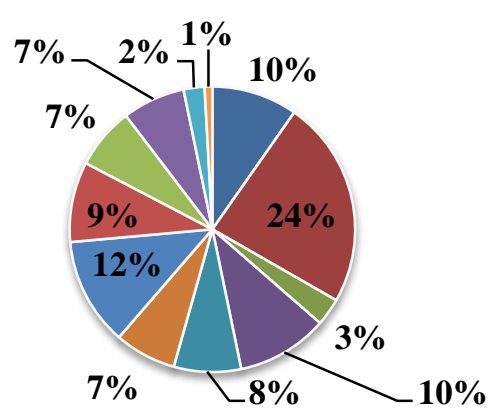

(b)

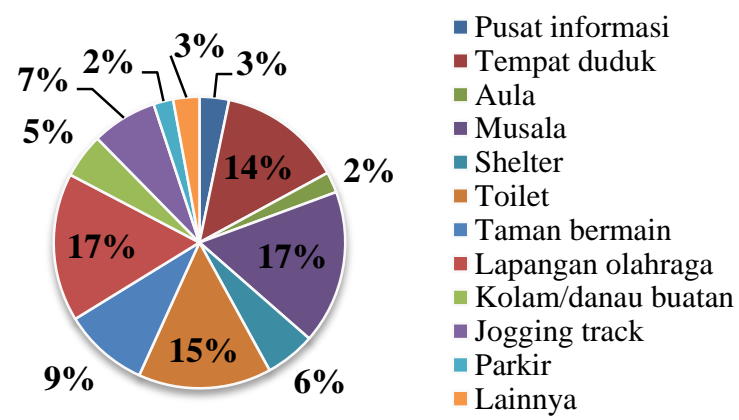

(d)

Gambar 36 Persentase preferensi responden terhadap fasilitas di (a) Taman Ayodya dan (b) Taman Martha Tiahahu, (c) Taman Tangkuban Perahu dan (d) Taman Mataram

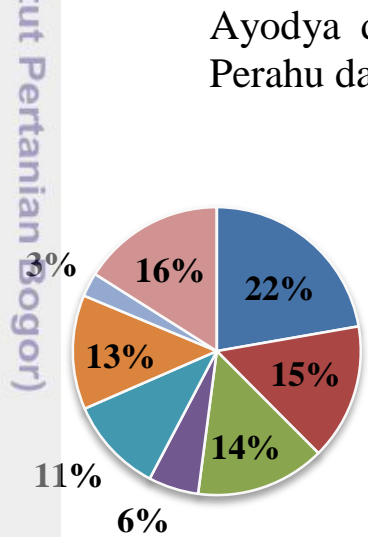

(a)

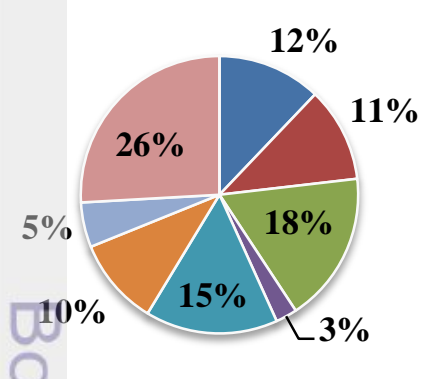

(c)

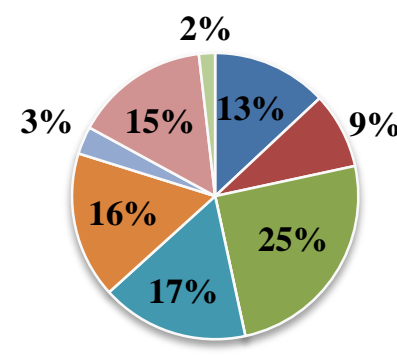

(b)

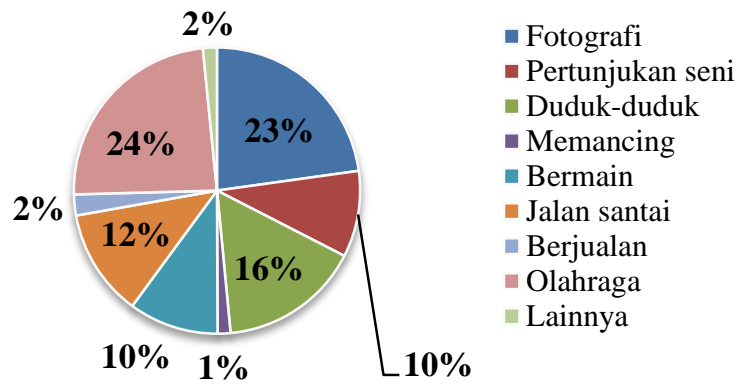

(d)

Gambar 37 Persentase preferensi responden terhadap aktivitas di (a) Taman Ayodya dan (b) Taman Martha Tiahahu, (c) Taman Tangkuban Perahu dan (d) Taman Mataram 
Preferensi responden terhadap fasilitas di Taman Ayodya terbanyak ialah musala. Lokasi taman yang berada diantara hotel, gereja dan pemukiman I membuat pengunjung yang tinggal jauh dari taman kesulitan mencari musala ketika memasuki waktu sholat. Masjid terdekat berada sekitar $1 \mathrm{~km}$ dari taman. Preferensi responden terbanyak terhadap aktivitas yang ingin ditambah di Taman Ayodya adalah fotografi karena tujuan pengunjung mayoritas untuk rekreasi.

Preferensi responden terhadap fasilitas di Taman Martha Tiahahu terbanyak adalah tempat duduk. Hal ini sejalan dengan preferensi responden terhadap aktivitas didalam taman. Pengunjung yang mayoritas mahasiswa dan . pegawai sering menggunakan taman ini untuk istirahat dan rekreasi, namun tidak banyak tempat duduk yang cukup untuk mengakomodasi kebutuhan tersebut. Tempat duduk yang sudah ada pun perlu diperbaiki karena banyak yang sudah rusak.

Preferensi responden terhadap fasilitas di Taman Tangkuban Perahu terbanyak ialah tempat duduk dan toilet. Pembuatan toilet dibutuhkan untuk mengakomodasi semua pengunjung taman meski letak taman yang bersebrangan dengan masjid. Berada diantara pemukiman menjadikan taman ini salah satu tempat re $\bar{k}$ reasi dan beristirahat. Preferensi responden terhadap aktivitas didalam taman terbanyak ialah olahraga. Taman ini sering digunakan untuk aktivitas jogging, permainan bulu tangkis, futsal, basket, dan pijat kaki (refleksi), namun fasilitas yang sudah ada belum dapat mengakomodasi semua kegiatan tersebut.

Preferensi responden terhadap fasilitas di Taman Mataram terbanyak ialah lapangan olahraga dan musala. Hal ini sejalan dengan aktivitas terbanyak yang diinginkan responden ialah olahraga dan fotografi. Taman yang aktif digunakan hari sabtut-minggu ini banyak digunakan sebagai area olahraga seperti jogging atau sekeđar duduk-duduk menikmati taman.

\subsection{Rekomendasi Pengembangan Tata Hijau Taman Kota}

Rekomendasi pengembangan tata hijau taman kota untuk mengoptimalkan fungsi taman sebagai peredam bising, modifikasi suhu, pengontrol kelembaban udara dan penahan angin serta estetika setiap taman yang diteliti. Berdasarkan penilaian fungsi ekologis dan estetika diketahui setiap taman mempunyai satu masalah utama. Taman ayodya baik dalam modifikasi suhu dan estetika taman, namun belum dapat mengontrol kelembaban udara. Karakter fisik tanaman, komposisi dan jarak antar tanaman dapat mempengaruhi tingkat kelembaban suatu taman. Karakter fisik tanaman yang dapat mengontrol kelembaban udara berdasarkan ketetapan oleh Bianpoen et al. (1989), Grey dan Deneke (1978) dan Carpenter et al. (1975), dan literatur lainnya seperti kerapatan daun rendah, berdaun jarum atau kasar, tekstur batang kasar dan jumlah daun banyak. Komposisi tanaman dengan kerapatan yang sedang dapat mengontrol kelembaban udara. Cemara norflok (Araucaria heterophylla) dan Pinus (Pinus merkusii) adalah beberapa tanaman yang dapat mengontrol kelembaban udara secara optimal. Contoh ilustrasi komposisi penanaman untuk mengontrol kelembaban udara berdasarkan hasil pengamatan dapat dilihat pada Gambar 38. 


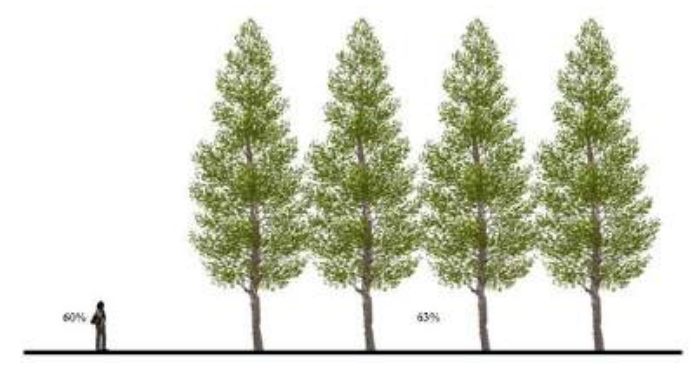

Gambar 38 Contoh ilustrasi komposisi tanaman pengontrol kelembaban udara berdasarkan hasil pengamatan

- Taman Ayodya merupakan taman dengan nilai estetika tertinggi. Perâeliharaan tanaman seperti penyiraman, pemupukan, pemangkasan, penyulaman dan pengendalian gulma serta penyakit tanaman yang sudah baik dipertahankan. Pembersihan kolam, pemberian pakan ikan dan memfungsikan air mañcur secara rutin serta perawatan bangunan taman juga diperhatikan agar estetika taman tetap terjaga keindahannya.

Taman Martha Tiahahu yang terletak diantara terminal, pusat perbelanjaan dan $\overline{\text { jalan }}$ raya mempunyai masalah utama taman yaitu fungsi taman sebagai peredam bising dan penahan angin. Karakter fisik tanaman yang dapat meredam

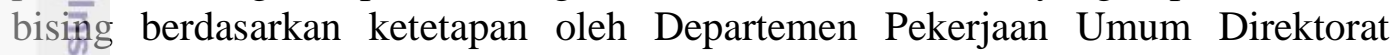
Jenđral Bina Marga (1996), Grey dan Deneke (1978) dan literatur lainnya seperti tajuk rapat dan massa daun rapat, berdaun tebal, struktur cabang dan batang besar sertä berdaun jarum. Komposisi tanaman pohon dan semak serta penempatan tanaman fungsi peredam bising dekat sumber suara dapat mengefektifkan pegärangan bising. Beberapa tanaman yang dapat meredam bising seperti Jelly palm (Butia capitata), Cemara norflok (Araucaria heterophylla) dan Canary island date palm (Phoenix canariensis). Contoh ilustrasi komposisi penanaman untek meredam bising berdasarkan hasil pengamatan dapat dilihat pada Gambar $39 . \stackrel{\circ}{9}$

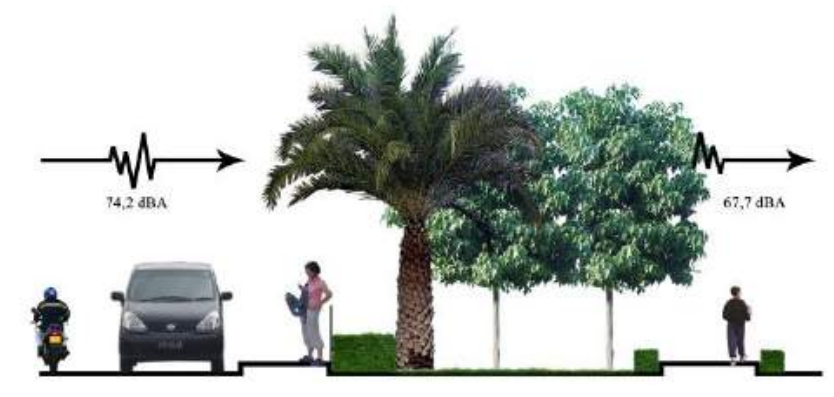

Gambar 39 Contoh ilustrasi tanaman peredam bising berdasarkan hasil pengamatan

Karakter fisik tanaman untuk penahan angin berdasarkan ketetapan oleh Carpenter et al. (1975), Dahlan (1992) dan Departemen Pekerjaan Umum Direktorat Jendral Bina Marga (1996) seperti tanaman tinggi, daun tidak mudah 
gugur, massa daun rapat dan berdaun tebal. Komposisi tanaman dengan perbedaan ketinggian dapat mengurangi kecepatan angin. Beberapa tanaman yang dapat I menahan angin seperti Beringin (Ficus benjamina), Cemara norflok (Araucaria heterophylla) dan Canary island date palm (Phoenix canariensis). Gambar 40 menunjukkan contoh ilustrasi komposisi tanaman penahan angin berdasarkan ' hasil pengamatan.

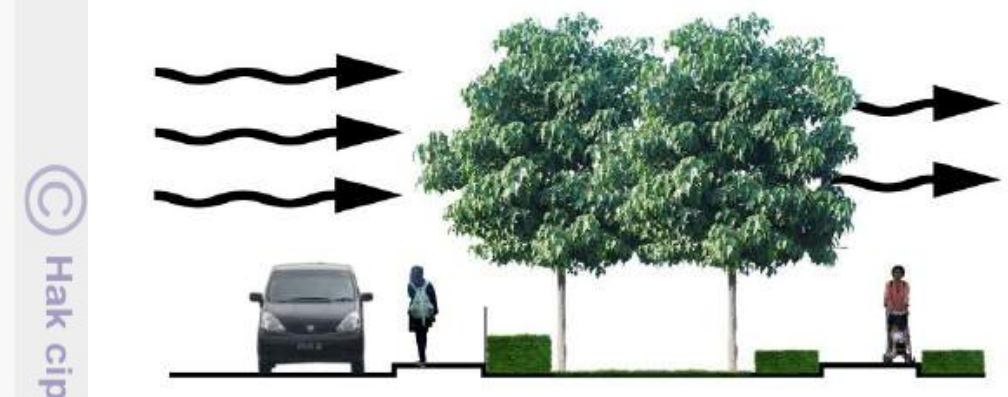

Gambar 40 Contoh ilustrasi komposisi tanaman penahan angin berdasarkan hasil pengamatan

Tamnan Martha Tiahahu merupakan taman dengan lawn terluas diantara taman yäng lain. Pemeliharaan tanaman seperti penyiraman, pemupukan, pemangkâsan tajuk semak, penyulaman dan pengendalian gulma serta penyakit tanaman perlu ditingkatkan. Pembersihan kolam dan memfungsikan air mancur secara rutin serta perawatan bangunan taman juga lebih diperhatikan agar estetika taman tetap terjaga keindahannya.

Taman Tangkuban Perahu adalah taman dengan fungsi peredam bising dan penahian angin yang baik diantara tiga taman yang lain. Akan tetapi, fungsi estetika đan kontrol kelembaban menjadi masalah utama di taman ini. Berdasarkan penilaian SBE, peningkatan nilai estetika taman dapat dipengaruhi pola desain, elemen taman dan ragam tanaman. Penerapan pola desain taman yang organik dạpat dilakukan dengan memperhatikan prinsip-prinsip desain agar taman menarik secara visual. Lima prinsip desain menurut Whiting dan De Jong (2012) yaitu adanya unity (kesatuan dari unsur-unsur yang disusun), balance (keseimbangan antar elemen taman), simplicity and variety (simpel dan variasi), emphasis (suatu elemen yang dapat dijadikan focal point atau kontras dengan elemen sekitarnya) dan sequence (irama antar elemen taman).

Elemen taman yang dominan elemen lunak seperti tanaman dengan ragam tanaman dari pohon hingga semak juga lebih disukai pengunjung. Oleh karena itu perlu penambahan tanaman display berupa tanaman berbunga dan berwarna di Taman Tangkuban Perahu. Beberapa tanaman semak yang dapat digunakan untuk menambah estetika seperti Hanjuang (Cordyline sp.), Teh-tehan (Acalypha macrophylla), Pisang hias (Heliconia sp.) Selain itu, perbaikan terhadap fasilitas taman seperti signage dapat menjadikan signage salah satu focal point dapat dilihat pada Gambar 41. Kontrol kelembaban taman ini dengan memangkas tajuk beberapa tanaman atau merelokasi beberapa tanaman agar jarak antar tanaman tidak terlalu rapat. 

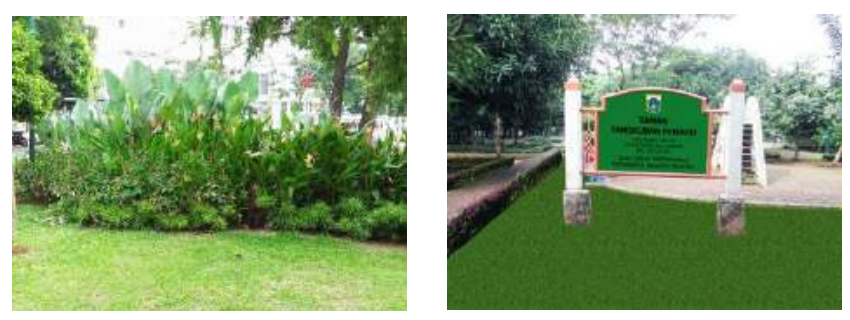

Gambar 41 Contoh ilustrasi fungsi estetika berdasarkan hasil pengamatan

Permasalah utama Taman Mataram adalah belum optimalnya fungsi modifikasi suhu. Karakter fisik tanaman yang dapat memodifikasi suhu (peneduh) berēasarkan ketetapan oleh Simonds (1983), Departemen Pekerjaan Umum Direktorat Jendral Bina Marga (1996), Carpenter et al. (1975) dan literatur lainnya seperti ketinggian kanopi lebih dari $2 \mathrm{~m}$, bentuk tauk spreading, bulat dome atau irreguler, massa daun padat dan daun tebal. Beberapa tanaman yang dapât memodifikasi suhu (peneduh) seperti Beringin (Ficus benjamina), Biola cantik (Ficus lyrata), Ketapang (Terminalia catappa) dan Trembesi (Samanea

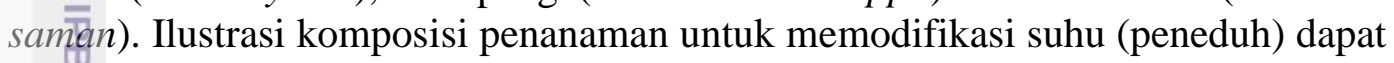
dilihat pada Gambar 42.
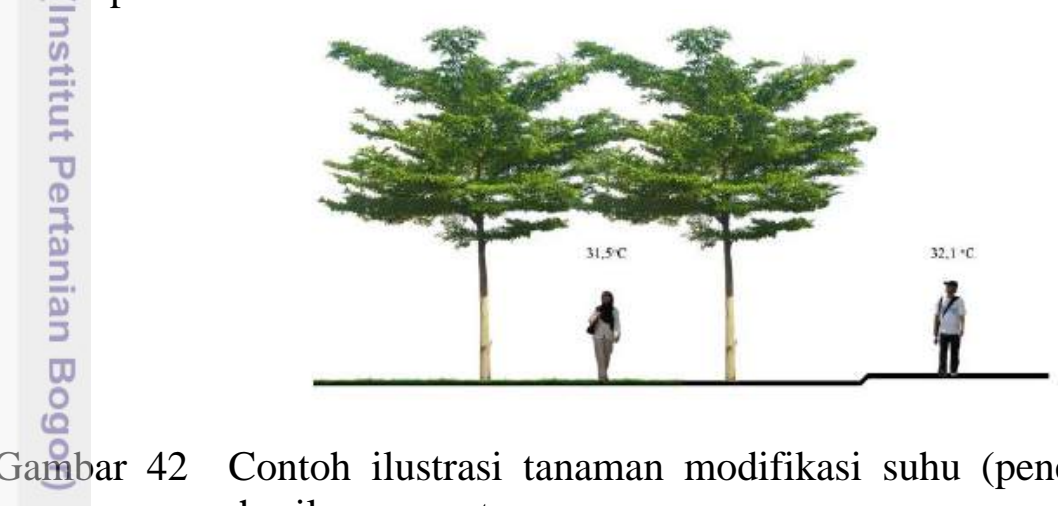

Gambar 42 Contoh ilustrasi tanaman modifikasi suhu (peneduh) berdasarkan hasil pengamatan

Taman Mataram merupakan taman dengan usia yang paling muda diantara ketiga taman lainnya. Pemeliharaan tanaman seperti penyiraman, pemupukan, penyulaman dan pengendalian gulma serta penyakit tanaman perlu ditingkatkan mengingat tanaman yang ada masih merupakan tanaman muda. Penambahan fasilitas seperti toilet dan mushola serta memperbaiki fasilitas yang ada seperti area olahraga serta perawatan bangunan taman juga diperhatikan agar estetika taman tetap terjaga dan meningkat keindahannya.

\section{SIMPULAN DAN SARAN}

\subsection{SIMPULAN}

Kondisi tanaman di empat taman relatif baik dan dipelihara secara insentif sehingga tumbuh dengan optimal. Hasil evaluasi fungsi ekologis menunjukkan Taman Tangkuban Perahu terbaik dalam fungsi peredam bising, modifikasi suhu 
64

(taman non-elemen air) dan penahan angin, Taman Ayodya terbaik dalam modifikasi suhu (taman berelemen air), Taman Martha Tiahahu terbaik dalam I fungsi kontrol kelembaban udara untuk taman berelemen air dan Taman Mataram terbaik dalam fungsi kontrol kelembaban udara untuk taman non-elemen air. Keberadaan taman sangat berpengaruh terhadap perbaikan kualitas lingkungan, suhu udara mampu diturunkan hingga $1,8^{\circ} \mathrm{C}$, kelembaban udara mampu diturunkan hingga 5\% dan kebisingan mampu direduksi hingga 9,2 dBA. Taman yang dilengkapi elemen air lebih mampu menurunkan suhu udara dibanding taman non-elemen air. Penilaian kualitas estetika tertinggi ialah Taman Ayodya . dan Taman Tangkuban Perahu memiliki kualitas terendah. Penyebaran kuesioner menghasilkan preferensi responden terhadap penambahan sarana dan prasarana di taman untuk mengakomodasi aktivitas. Selain itu, pola desain organik dengan elemen dominan softscape (tanaman, air) dapat menambah keindahan taman $\subsetneq$ karena memberi kesan menarik dan tidak monoton.

\subsection{SARAN}

Penelitian ini diharapkan dapat menjadi salah satu acuan dalam pembangunan taman di kota dengan memperhatikan aspek fungsi ekologis dan estetika. Penggunaan tanaman sebaiknya disesuaikan dengan fungsi yang dibutuhkan agar kondisi ekologis dan estetika lebih optimal. Pengaplikasian prinsip désain juga dibutuhkan agar taman lebih estetik.

\section{DAFTAR PUSTAKA}

[BMKG] Badan Meteorologi, Klimatologi dan Geofisika. 2016. Data Kelembaban Udāra dan Data Suhu Maksimum Stasiun Klimatologi Pondok Betung. Jakarta (ID): Manajemen Database MKKuG

[Kemendagri] Kementerian Dalam Negeri. 2007. Peraturan Menteri Dalam Negeri Republik Indonesia Nomor 1 Tahun 2007 tentang penataan Ruang Terbuka Hijau di Wilayah Perkotaan. Jakarta (ID): Kemendagri.

[KemenLH] Kementerian Lingkungan Hidup. 1996. Keputusan Menteri Lingkungan Hidup Nomor 48 Tahun 1996 tentang Baku Tingkat Kebisingan. Jakarta (ID): KemenLH.

Abello RP, Bernaldez FG. 1986. Landscape Preference amd Personality. Landscape and Urban Planning, 13(1986):19-28

Arifin HS, Munandar A, Arifin NHS, Pramukanto Q, Damayanti VD. 2008. Sampoerna Hijau Kotaku Hijau. Bogor: Sampoerna Hijau.

Bergen SD. 1993. Mitigating Potential Impact to Visual Quality During the Design of Forest Operational Plans[thesis]. Washington (USA): University of Washington.

Booth NK. 1983. Basic Elements of Landscape Architecture Design. Illnois: Waveland Press inc.

Carpenter PL, Walker TD, Lanphear FO. 1975. Plants in The Landscape. San Fransisco (ID): W. H. Freeman and Co. 481p.

Dahlan EN. 1992. Membangun Kota Kebun (Garden City) Bernuansa Hutan Kota. Bogor (ID): IPB Pr. 
Daniel TC, Boster RS. 1976. Measuring Landscape Aesthetics: the Scenic Beauty Estimation Method. USDA Forest Service Research Paper. RM- 167.

Eckbo G. 1964. Urban Landscape Design. New York: Mc.Graw-Hill Book Co. 248p.

Forman RTT, Gordon M. 1986. Landscape Ecology. USA: John Willey \& Sons.

Grey GW, F.J. Deneke. 1978. Urban Forestry. New York: John Willey and Sons inc.

Hadinoto K. 1950. Kebajoran, A New Town Under Construction. Jakarta: Van Dorp Djakarta.

Heath TF. 1988. Behavioral and Perceptual Aspects of The Aesthetics of Urban Environments. New York: Cambridge Univ Pr. hlm. 6-10.

Hidayat AMA. 2010. Studi Evaluasi Taman Kota sebagai Taman Terapeutik

긋 (Studi Kasus: Taman Cilaki Atas, Kota Bandung) [skripsi]. Bogor (ID):

气. Institut Pertanian Bogor.

Hidayat I. 2008. Evaluasi Jalur Hijau Jalan sebagai Penyangga Lingkungan

3 Sekitarnya dan Keselamatan Pengguna Jalan Bebas Hambatan Jagorawi

[thesis]. Bogor (ID): Institut Pertanian Bogor.

Kaplan S. 1988. Perception and Landscape: Conception and Misconceptions. In

Jack LN. Editor. Enviromental Aesthetics. New York (US): Cambridge

= Univ Pr. 44-45p.

Laurie M. 1986. Pengantar kepada Arsitektur Pertamanan (terjemahan) Terbitan

kedua. Penerbit Intermatra. Bandung. 103 hal.

Mahrardi F. 2013. Evaluasi Fungsi Ekologis dan Estetika Pada Beberapa Taman

¿ Kota Di Jakarta [skripsi]. Bogor (ID): Institut Pertanian Bogor.

Nassarar JL. 1988. Environmental Aesthetic Theory, Research and Applications.

New York (US): Cambridge Univ Pr. 529p.

Nựsjah S. 2005. Penilaian Masyarakat terhadap Ruang Terbuka Hijau (RTH)

Jo Wilayah Perkotaan: Kasus Kotamadya Bogor [disertasi]. Bogor (ID):

$\because$ Institut pertanian Bogor.

Pemerintah Republik Indonesia. 2007. Undang-Undang Republik Indonesia Nomor 26 Tahun 2007 tentang Penataan Ruang. Jakarta (ID): Sekretariat Negara.

Permata DLJ. 2002. Preferensi Masyarakat terhadap Lanskap Visual Pemukiman (Studi Kasus Pemukiman di Kabupaten Cianjur dan Kotamadya Bogor). [skripsi]. Bogor (ID): Institut Pertanian Bogor.

Porteous JD. 1977. Environment and Behavior Planning and Everyday Urban Life. New York: Addison-Wesley Publishing Company. 446p.

Porteous JD. 1983. Environtmental Aesthetics: Idea, Politics dan Planning. New York: Cambridge University Press. 529p. (Terjemahan)

Sembiring E. 2005. Analisis Tentang Fungsi Ruang Terbuka Hijau. [tesis]. Medan (ID): Universitas Sumatera Utara.

Simonds JO. 1983. Landscape Architecture. New York: Mc Graw - Hill Book Co.

Whiting D, De JJ. 2012. Ater ise Landscape Design: Principles of Landscape Design. Colorado (US): Colorado State University Extension.

Wūngkar MM. 2005. Evaluasi Aspek Fungsi dan Kualitas Estetika Arsitektural Pohon Lanskap Jalan Kota Bogor [tesis]. Bogor (ID): Institut Pertanian Bogor. 


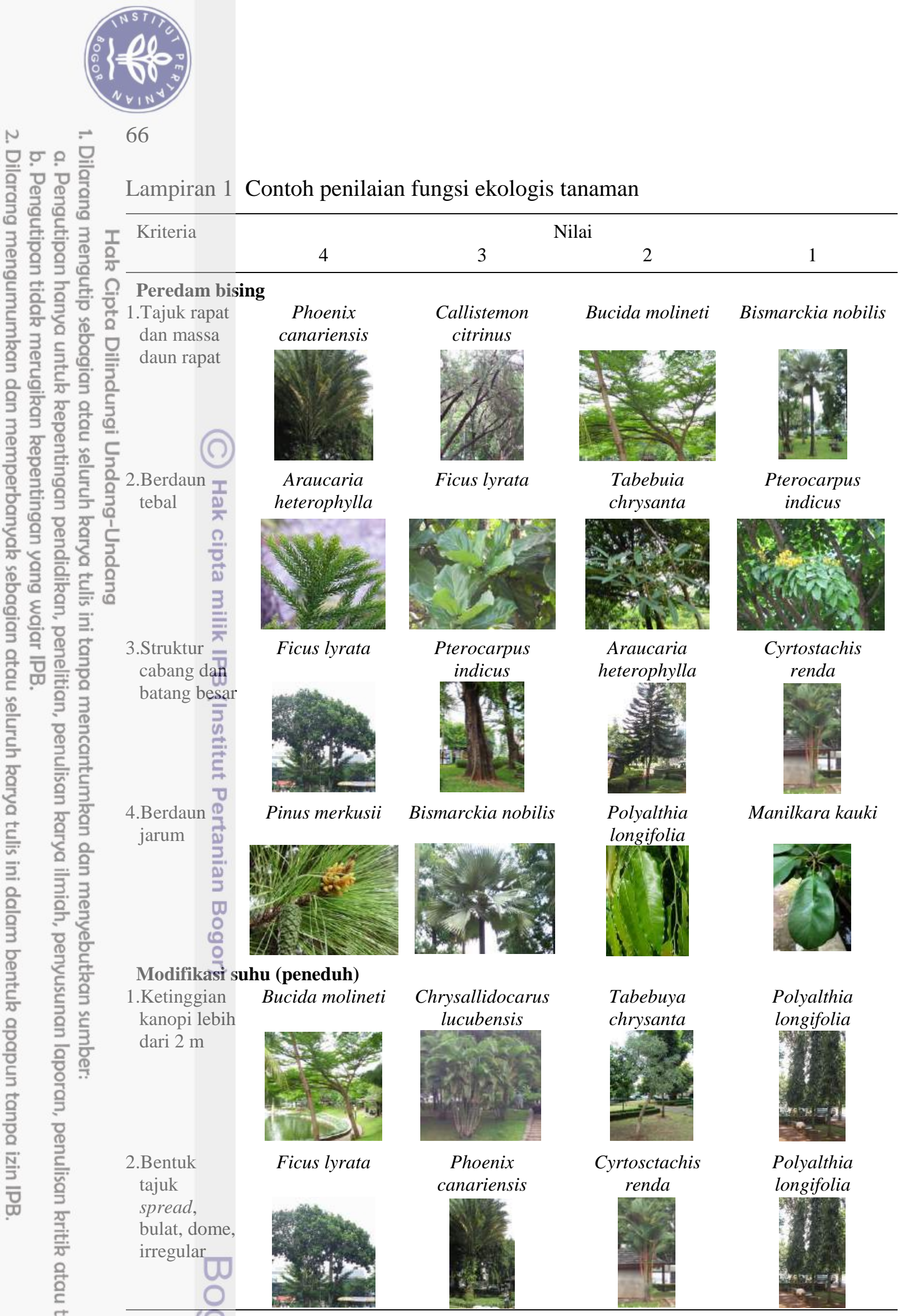




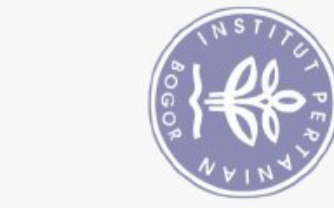

\section{Daun tebal}

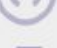

$\frac{T}{\frac{\pi}{\pi}}$

ำำ

\section{Kontrol kelembaban}

1.Kêrapatan damn rendah

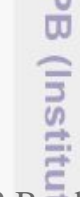

2.Berdaun jarum atau kașar

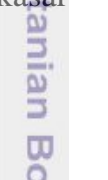

3. Tekstur batang kasar

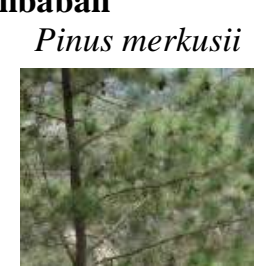

Bis

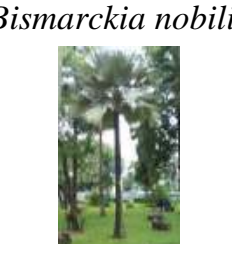

Pinus merkusii
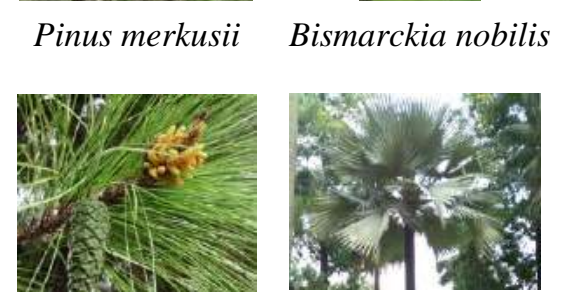

Araucaria heterophylla

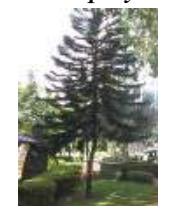

\section{Jumlah daun} banyak
Araucaria heterophylla

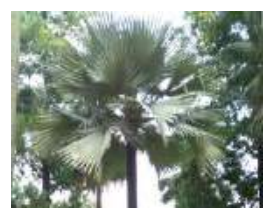

Mimusoph elengi

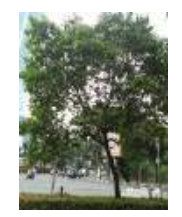

Mimusoph elengi

$$
\text { Ficus lyrata }
$$

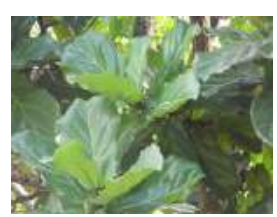
Nilai

2

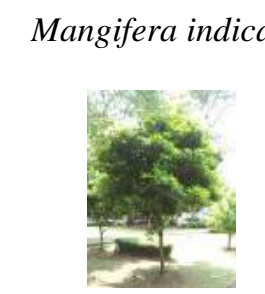

Plumeria rubra

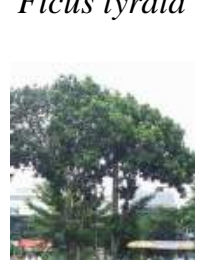

Tabebuia
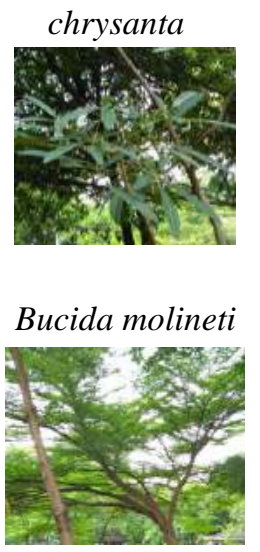

Polyalthia

longifolia

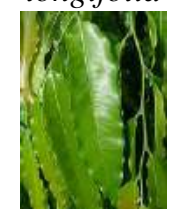

Plumeria rubra

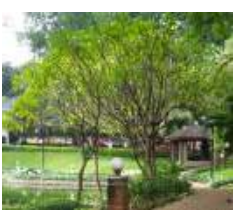

Veitchia merilii
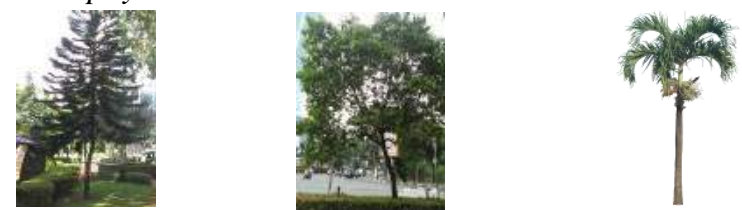

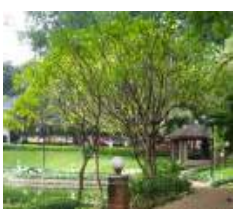

Pterocarpus indicus

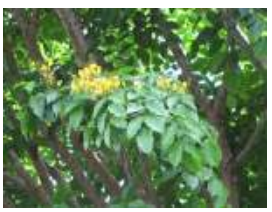

Ficus lyrata

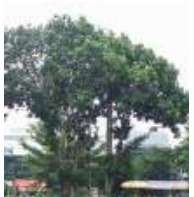

Manilkara kauki

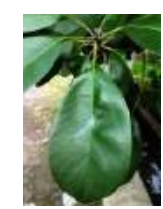

Rainbow eucalyptus

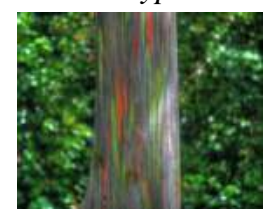

Bismarckia nobilis

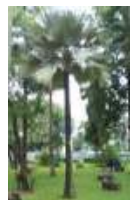



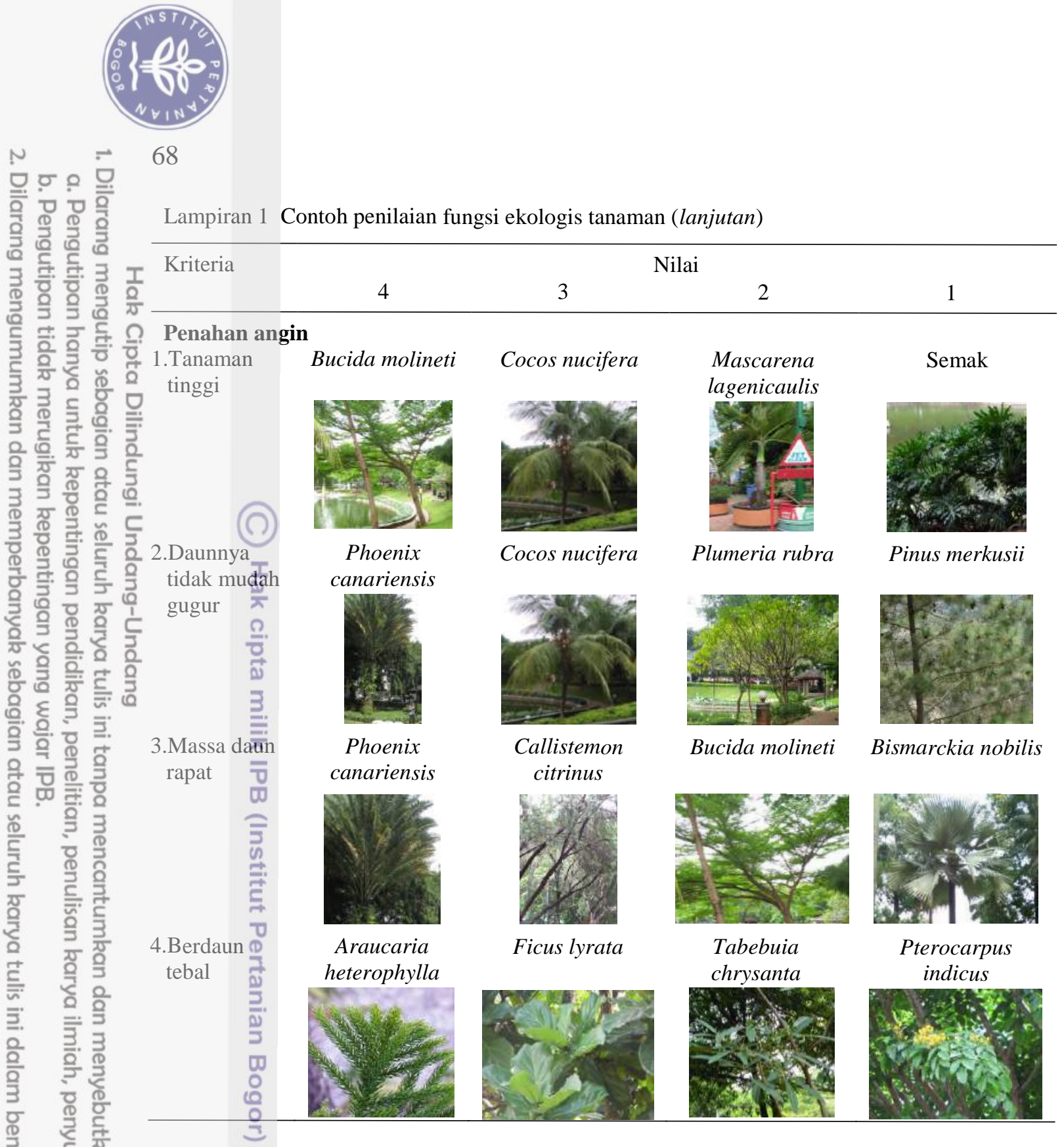
Lampiran 2 Kuesioner pengunjung Taman Ayodya dan Taman Martha Tiahahu

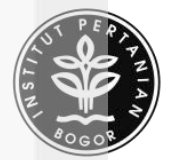

DEPARTEMEN ARSITEKTUR LANSKAP

FAKULTAS PERTANIAN

INSTITUT PERTANIAN BOGOR

Kuesioner Penelitian

EVALUASI FUNGSI EKOLOGIS DAN ESTETIKA PADA BEBERAPA TAMAN KOTA DI JAKARTA SELATAN

Tanggal Pengambilan :

No. Kuesioner

Assălamualaykum Wr. Wb.

Saya Yuanita Asgitami, mahasiswa semester 8 Departemen Arsitektur Lanskap di Instiftut Pertanian Bogor. Saya mengharapkan bantuan dari Bapak/Ibu/Kakak/Adik untuk mengisi kuesioner penelitian saya yang berjudul Evaluasi Fungsi Ekologis dan Estetika pada Beberapa Taman Kota di Jakarta Selatan. Terima kasih atas kesễdiaannya.

\section{A. Karakteristik Responden}

1. Nama

2. Umur

3. Jenis kelamin

4. Daerah Asal

5. Pẹndidikan terakhir Anda:
Ja. SD
b. SMP
c. SMA

d. Perguruan tinggi

e. Lainnya

6. Pekerjaan/Profesi Anda saat ini:
a. Pelajar
Jd. Wiraswasta
b. Mahasiswa
c. Pegawai (Negeri/Swasta)
e. Lainnya.

\section{B. Preferensi Responden}

7. Tujuan Anda mengunjungi taman:
a. Rekreasi
b. Belajar
c. Berbelanja
d. Ingin tahu
e. Lainnya

8. Kunjungan Anda ke taman untuk:
a. Pertama kali
b. Kedua kali
c. Ketiga kali
d. Lebih dari ketiga kali

9. Lama kunjungan Anda di taman:
a. $<30$ menit
b. 30-60 menit
c. 1-2 jam

d. $>2$ jam

10. Frekuensi kunjungan Anda:
ca. Setiap hari
b. Setiap minggu
c. Setiap bulan
d. Tidak tentu
e. Lainnya

11. Jarak taman dari tempat tinggal Anda:
a. $<500 \mathrm{~m}$
b. $500 \mathrm{~m}-1 \mathrm{~km}$
c. $>1 \mathrm{~km}$
Od. $1-3 \mathrm{~km}$
e. $>3 \mathrm{~km}$ 
C. Persepsi Responden

13. Kesan Anda tentang pemandangan taman:
a. Sangat indah
b. Indah
c. Sedang
d. Jelek
e. Sangat jelek
Lokasi mana saja yang menurut Anda indah?

14. Kesan Anda tentang penataan taman:
a. Sangat indah
b. Indah
c. Sedang
d. Jelek
e. Sangat jelek

Lokasi mana saja yang menurut Anda indah?

15. Kesan-Anda terhadap kenyamanan suhu di taman:
a. Sangat sejuk
b. Sejuk
c. Sedang
d. Panas
e. Sangat panas
Lokasi mana saja yang menurut Anda sejuk?

16. KesantAnda tentang kebisingan taman:
a. Sañgat tenang
b. Tenang
c. Sedang
d. Bising
e. Sangat bising

Lokasi mana saja yang menurut Anda tenang?

17. Kesan Anda tentang hembusan angin pada taman:
a. Sañgat pelan
b. Pelan
c. Sedang
d. Kencang
e. Sangat kencang

Lokași mana saja yang menurut Anda pelan?

18. Kesam Anda tentang kelembaban udara taman:
a. Sangat kering
b. Kering
c. Sedang
d. Lémbab
e. Sangat lembab
Lokasi mana saja yang menurut Anda lembab?

19. Kesan Anda terhadap kebersihan taman:
a. Sangat bersih
b. Bersih
c. Sedang
d. Kotor
e. Sangat kotor

20. Kesan Anda terhadap kolam/danau pada taman:
a. Sangat indah
b. Indah
c. Sedang
d. Jelek
e. Sangat jelek

21. Lokasi mana yang paling Anda disenangi? (jawaban minimal tiga (3))

Lokasi

a. Gerbang utama

b. Jatan setapak

c. Kolam/danau

d. Area bermain

e. Kursi-kursi taman

f. Lapangan terbuka

g. WC umum

h. Parkir kendaraan
Ranking 
i. Lainnya (sebutkan)

22. Aktivitas/kegiatan apa saja yang ingin Anda lakukan, jika kawasan taman ini akan dikembangkan lebih lanjut? (jawaban minimal tiga (3))

Kegiatan

Ranking

a. Fotografi

b. Pertunjukan seni

c. Duduk-duduk

d. Memancing

e. Bermain

f. Jalan santai

g. Berjualan

th. Olahraga

i. Lainnya (sebutkan)

23. Jenis fasilitas apa saja yang Anda inginkan untuk menunjang kegiatan tersebut? (jawaban minimal tiga (3))
3 Fasilitas
. Pusat informasi
b. Tempat duduk
c. Aula
d. Musala
Shelter
f. Toilet
g. Taman bermain
फ. Lapangan olahraga
i. Kolam/danau buatan
J. Jogging track
k. Parkir
प. Lainnya (sebutkan)

24. Apakah anda merasa puas berkunjung ke taman ini?
a. Sangat puas
b. Puas
d. Tidak puas
e. Sangat tidak puas
c. Sedang

Ranking

25. Saran dan harapan Anda untuk Taman ini.

Terima kasih atas partisipasi Anda

Wassalamualaykum Wr.Wb 
Lampiran 3 Kuesioner pengunjung Taman Tangkuban Perahu dan Taman Mataram

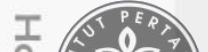

DEPARTEMEN ARSITEKTUR LANSKAP

FAKULTAS PERTANIAN

INSTITUT PERTANIAN BOGOR

Kuesioner Penelitian

EVALUASI FUNGSI EKOLOGIS DAN ESTETIKA PADA BEBERAPA TAMAN KOTA DI JAKARTA SELATAN

Tanggal Pengambilan :

No. Kuesioner

Assalamualaykum Wr. Wb.

ᄃ Saya Yuanita Asgitami, mahasiswa semester 8 Departemen Arsitektur Lanskap di

Institut Pertanian Bogor. Saya mengharapkan bantuan dari Bapak/Ibu/Kakak/Adik untuk mengisi kuesioner penelitian saya yang berjudul Evaluasi Fungsi Ekologis

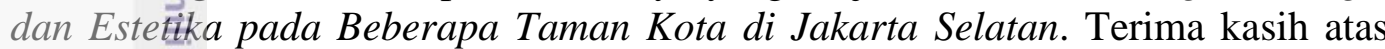
kesediaan̄y. 孟

A. Karakteristik Responden

1. Nama

2. Umur

3. Jenis kelamin

4. Daerahosal :

5. Pendidik an terakhir Anda:
a. $\mathrm{SD}$.
b. SMP
c. SMA
d. Perguruan tinggi
e. Lainnya

6. Pekerjaan/Profesi Anda saat ini:
a. Pepajar
b. Mahasiswa
c. Pegawai (Negeri/Swasta)
d. Wiraswasta
e. Lainnya

B. Preferensi Responden

7. Tujuan Anda mengunjungi taman:
a. Rekreasi
b. Belajar
c. Berbelanja
d. Ingin tahu
e. Lainnya

8. Kunjungan Anda ke taman untuk:
a. Pertama kali
b. Kedua kali
c. Ketiga kali
d. Lebih dari ketiga kali

9. Lama kunjungan Anda di taman:
a. $<30$ menit
b. 30-60 menit
c. 1-2 jam
d. $>2$ jam

10. Frekuensi kunjungan Anda:
a. Setiap hari
b. Setiap minggu
c. Setiap bulan
d. Tidak tentu
e. Lainnya

11. Jarak taman dari tempat tinggal Anda:
a. $<500 \mathrm{~m}$
b. $500 \mathrm{~m}-1 \mathrm{~km}$
c. $>1 \mathrm{~km}$
d. $1 \ominus 3 \mathrm{~km}$
e. $>3 \mathrm{~km}$ 
C. Persepsi Responden

13. Kesan Anda tentang pemandangan taman:
a. Sangat indah
b. Indah
c. Sedang
d. Jelek
e. Sangat jelek
Lokasi mana saja yang menurut Anda indah?

14. Kesan Anda tentang penataan taman:
a. Sangat indah
b. Indah
c. Sedang
d. Jelek
e. Sangat jelek

Lokasi mana saja yang menurut Anda indah?

15. Kesan Anda terhadap kenyamanan suhu di taman:
a. Sangat sejuk
b. Sejuk
c. Sedang
@d. Panas
e. Sangat panas

Lokasi mana saja yang menurut Anda sejuk?

16. Kesan Anda tentang kebisingan taman:
a. Sangat tenang
b. Tenang
c. Sedang
d. Bising
e. Sangat bising
Lokasi mana saja yang menurut Anda tenang? (n.

17. Kesan Anda tentang hembusan angin pada taman:
a. Sangat pelan
b. Pelan
c. Sedang
d. Kencang
e. Sangat kencang
Lokasi mana saja yang menurut Anda pelan?

18. Kesan Anda tentang kelembaban udara taman:
Ta. Sangat kering
b. Kering
c. Sedang
od. Lembab
e. Sangat lembab
Jokasi mana saja yang menurut Anda lembab?

19. Kesan Anda terhadap kebersihan taman:
a. Sangat bersih
b. Bersih
c. Sedang
d. Kotor
e. Sangat kotor

20. Lokasi mana yang paling Anda disenangi? (jawaban minimal tiga (3))

Lokasi

Ranking

a. Gerbang utama

b. Jalan setapak

c. Area bermain

d. Kursi-kursi taman

o. Lapangan terbuka

WC umum

g. Parkir kendaraan

Ch. Lainnya (sebutkan).

22. Aktivitas/kegiatan apa saja yang ingin Anda lakukan, jika kawasan taman ini Jakan dikembangkan lebih lanjut? (jawaban minimal tiga (3)) 
Kegiatan

Ranking

a. Fotografi

b. Pertunjukan seni

c. Duduk-duduk

d. Memancing

e. Bermain

f. Jalan santai

g. Berjualan

h. Olahraga

i. Lainnya (sebutkan)

23. Jenis fasilitas apa saja yang Anda inginkan untuk menunjang kegiatan tersebut? (jawaban minimal tiga (3))

Easilitas

a. Pusat informasi

b. Tempat duduk

c. Auta

d. Müsala

e. Shêlter

f. Toifet

g. Taman bermain

h. Lapangan olahraga

i. Kotăm/danau buatan

j. Jogging track

k. Parkir

1. Lawhya (sebutkan)

24. Apak han anda merasa puas berkunjung ke taman ini?
a. Sangat puas
b. Puas
d. Tidak puas
e. Sangat tidak puas
c. Sedang

25. Sarandan harapan Anda untuk Taman ini.

\section{Terima kasih atas partisipasi Anda}

Wassalamualaykum Wr.Wb 
Lampiran 4 Kuesioner Scenic Beauty Estimation

KUESIONER

Evaluasi Kualitas Estetika Pada Beberapa Taman Kota di Jakarta Selatan

Data Responden

Jenis Kelamin :

Usia

Departemen

Semester

\section{Skala Penilaian Responden}

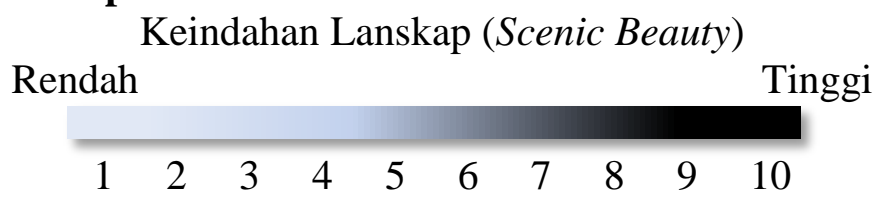

Penilaian Lanskap

\begin{tabular}{|c|c|c|c|}
\hline 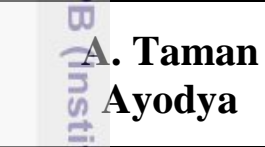 & $\begin{array}{c}\text { B. Taman } \\
\text { Martha Tiahahu }\end{array}$ & $\begin{array}{c}\text { C. Taman } \\
\text { Tangkuban } \\
\text { Perahu }\end{array}$ & $\begin{array}{c}\text { D. Taman } \\
\text { Ujung Lauser }\end{array}$ \\
\hline 1. . & $1 . \ldots \ldots$ & $1 \ldots \ldots$ & $1 . \ldots . .$. \\
\hline 2. ...... & $2 . \ldots \ldots$ & 2. ...... & 2. ...... \\
\hline 3. . . . . & 3. ...... & 3. ...... & 3. ....... \\
\hline 4. . .. & 4. ...... & 4. ....... & 4. ....... \\
\hline 5. . & 5....... & 5....... & 5....... \\
\hline 6. . & 6. ...... & 6. ....... & 6. ...... \\
\hline 7. .... & 7. ...... & 7. ...... & 7. ....... \\
\hline 8. ... & 8. ...... & 8. ...... & 8. ...... \\
\hline $9 . \ldots . .$. & $9 . \ldots \ldots$ & $9 . \ldots \ldots$ & $9 . \ldots \ldots$ \\
\hline $10 . \ldots \ldots$ & $10 . \ldots \ldots$ & $10 . \ldots \ldots$ & $10 . \ldots \ldots$ \\
\hline $11 . \ldots \ldots$ & $11 \ldots \ldots$ & $11 . \ldots \ldots$ & $11 . \ldots \ldots$ \\
\hline 12. ...... & $12 . \ldots \ldots$ & 12. ....... & $12 . \ldots \ldots$ \\
\hline $13 . \ldots \ldots$ & $13 . \ldots \ldots$ & 13. ....... & 13. ....... \\
\hline $14 . \ldots \ldots$. & 14....... & 14. ....... & 14. ....... \\
\hline $15 . \ldots \ldots$ & $15 . \ldots \ldots$ & $15 . \ldots \ldots$ & $15 . \ldots \ldots$ \\
\hline $16 . . . . .$. & $16 . \ldots \ldots$ & $16 . \ldots \ldots$ & 16. ....... \\
\hline 17. ...... & $17 . \ldots .$. & $17 . \ldots \ldots$ & $17 . \ldots .$. \\
\hline $18 . \ldots \ldots$ & $18 . \ldots \ldots$ & 18. ....... & $18 . \ldots \ldots$ \\
\hline $19 . \ldots \ldots$ & $19 . \ldots \ldots$ & $19 . \ldots \ldots$ & $19 . \ldots \ldots$ \\
\hline $20.0 . . .$. & $20 . \ldots \ldots$ & $20 \ldots \ldots$ & $20 . \ldots \ldots$ \\
\hline
\end{tabular}

\section{Komentar:}


Lampiran 5 Data pengukuran suhu udara maksimum $\left({ }^{\circ} \mathrm{C}\right)$ pertahun di Stasiun Klimatologi Pondok Betung, Jakarta Selatan 10 tahun terakhir

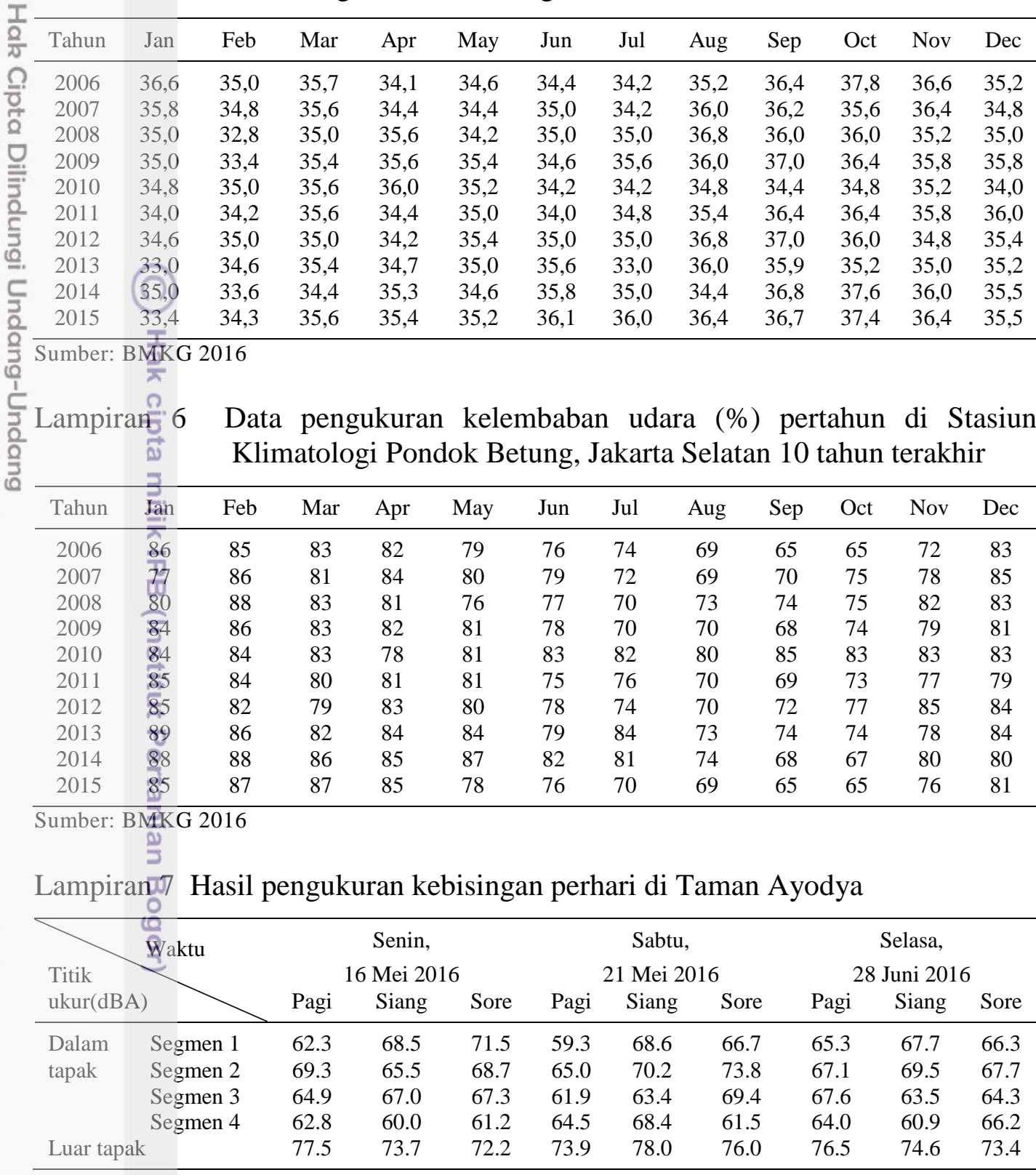

Lampiran 8 Hasil pengukuran kebisingan perhari di Taman Martha TIahahu

\begin{tabular}{|c|c|c|c|c|c|c|c|c|c|}
\hline \multirow{2}{*}{$\begin{array}{l}\text { Titik } \\
\text { ukur(dBA) }\end{array}$} & \multicolumn{3}{|c|}{$\begin{array}{c}\text { Kamis, } \\
19 \text { Mei } 2016\end{array}$} & \multicolumn{3}{|c|}{$\begin{array}{c}\text { Minggu, } \\
22 \text { Mei } 2016\end{array}$} & \multicolumn{3}{|c|}{$\begin{array}{c}\text { Senin, } \\
23 \text { Mei } 2016\end{array}$} \\
\hline & Pagi & Siang & Sore & Pagi & Siang & Sore & Pagi & Siang & Sore \\
\hline Dalam & 69.1 & 60.7 & 75.0 & 67.4 & 71.5 & 73. & 70.1 & 73.3 & 72.6 \\
\hline tapak & 61.4 & 71.1 & 74.2 & 62.7 & 68.2 & 72.3 & 61.7 & 72.4 & 70.5 \\
\hline & 61.9 & 73.4 & 69.3 & 62.4 & 67.3 & 71.0 & 61.7 & 70.8 & 69.9 \\
\hline Segmen 4 & 61.9 & 68.6 & 77.2 & 64 & 63.7 & 62.6 & 66.4 & 64.8 & 72.8 \\
\hline Luar tapak & 72.5 & 75.4 & 77.3 & 74.7 & 74.7 & 76.0 & 73.3 & 75.5 & 76.7 \\
\hline
\end{tabular}


Lampiran 9 Hasil pengukuran kebisingan perhari di Taman Tangkuban Perahu

\begin{tabular}{|c|c|c|c|c|c|c|c|c|c|c|}
\hline \multirow{2}{*}{$\begin{array}{l}\text { Titik } \\
\text { ukur(dBA) }\end{array}$} & \multirow{2}{*}{ Waktu } & \multicolumn{3}{|c|}{$\begin{array}{c}\text { Minggu, } \\
15 \text { Mei } 2016\end{array}$} & \multicolumn{3}{|c|}{$\begin{array}{c}\text { Selasa, } \\
24 \text { Mei } 2016\end{array}$} & \multicolumn{3}{|c|}{$\begin{array}{c}\text { Sabtu, } \\
\text { 25 Juni } 2016\end{array}$} \\
\hline & & Pagi & Siang & Sore & Pagi & Siang & Sore & Pagi & Siang & Sore \\
\hline Dalam & Segmen 1 & 76.6 & 64.6 & 65.7 & 73.4 & 67.3 & 63.4 & 68.1 & 70.8 & 71.8 \\
\hline \multirow[t]{3}{*}{ tapak } & Segmen 2 & 69.2 & 69.8 & 60.6 & 71.2 & 65.5 & 68.3 & 69.2 & 60.9 & 67.1 \\
\hline & Segmen 3 & 75.9 & 67.9 & 61.4 & 67.8 & 61.2 & 59.6 & 68.3 & 67.0 & 63.4 \\
\hline & Segmen 4 & 77.0 & 67.7 & 74.8 & 73.4 & 60.0 & 68.1 & 74.1 & 61.5 & 61.9 \\
\hline Luar tapak & & 79.1 & 72.8 & 75.7 & 75.5 & 74.2 & 74.6 & 73.0 & 71.3 & 72.1 \\
\hline
\end{tabular}

Lampiran 10 Hasil pengukuran kebisingan perhari di Taman Mataram

\begin{tabular}{|c|c|c|c|c|c|c|c|c|c|c|}
\hline \multirow{2}{*}{$\begin{array}{l}\text { Titik } \\
\text { ukur }(\mathrm{dBA})\end{array}$} & \multirow{2}{*}{ Waktu } & \multicolumn{3}{|c|}{$\begin{array}{c}\text { Rabu, } \\
18 \text { Mei } 2016\end{array}$} & \multicolumn{3}{|c|}{$\begin{array}{l}\text { Minggu, } \\
\text { 26 Juni } 2016\end{array}$} & \multicolumn{3}{|c|}{$\begin{array}{l}\text { Senin, } \\
\text { 27 Juni } 2016\end{array}$} \\
\hline & & Pagi & Siang & Sore & Pagi & Siang & Sore & Pagi & Siang & Sore \\
\hline DaTam & Segmen 1 & 71.4 & 71.2 & 67.9 & 54.8 & 56.5 & 65.9 & 67.8 & 70.2 & 64.4 \\
\hline tapak & Segmen 2 & 57.3 & 59.3 & 57.2 & 55.9 & 52.7 & 52.6 & 53.6 & 52.6 & 53.3 \\
\hline 3 & Segmen 3 & 53.5 & 53.9 & 53.1 & 58.3 & 57.1 & 56.1 & 52.6 & 54.5 & 53.3 \\
\hline$\equiv$ & Segmen 4 & 66.5 & 73.2 & 61.9 & 62.1 & 67.3 & 59.5 & 63.0 & 67.1 & 67.8 \\
\hline Luar tapak & & 65.0 & 66.2 & 66.6 & 62.8 & 65.7 & 64.1 & 65.3 & 67.7 & 68.7 \\
\hline
\end{tabular}

$$
0
$$

Lampiran 11 Hasil pengukuran suhu perhari di Taman Ayodya

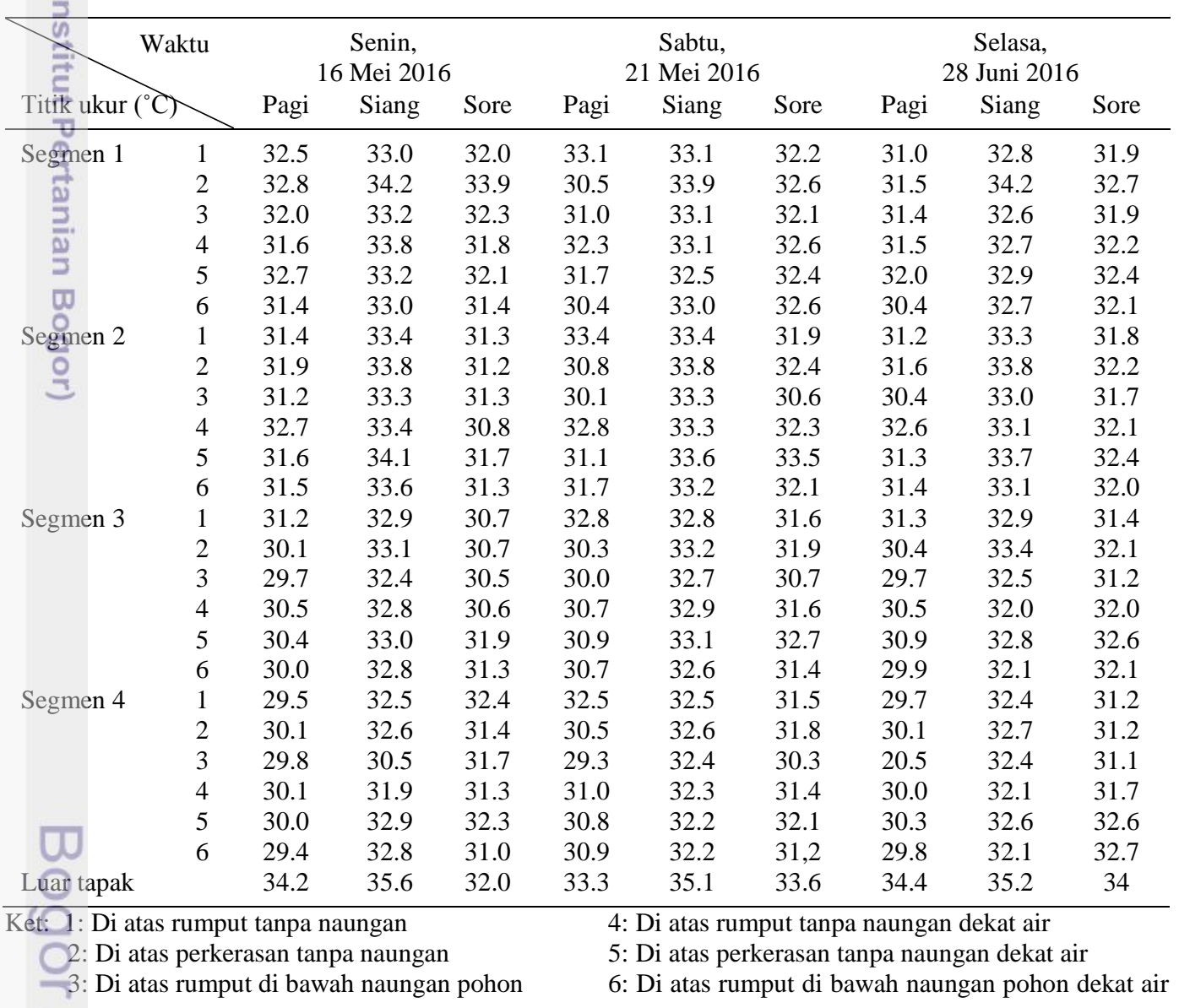




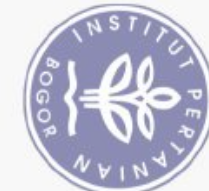

Lampiran 12 Hasil pengukuran suhu perhari di Taman Martha Tiahahu

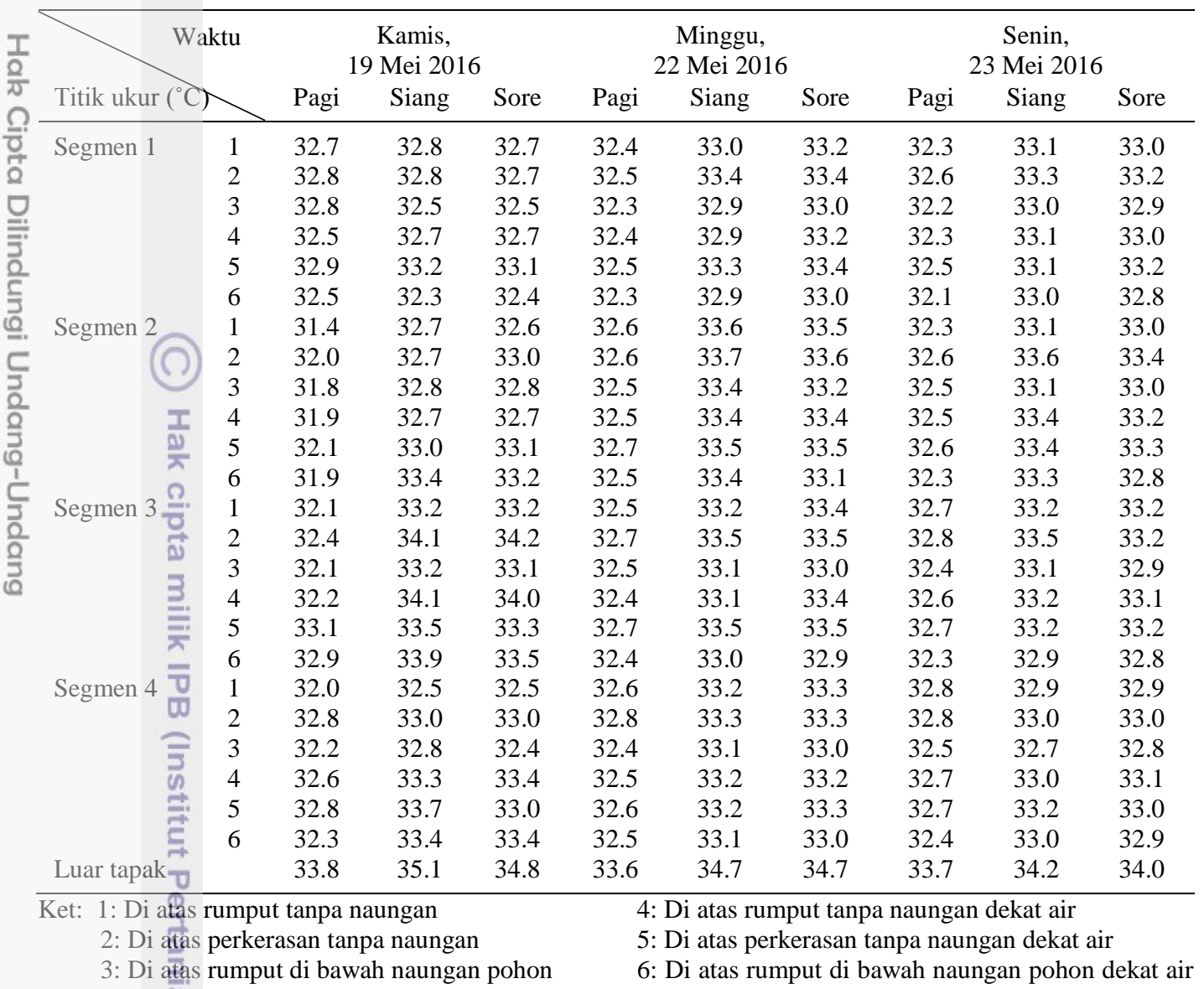

Lampirand 3 Hasil pengukuran suhu perhari di Taman Tangkuban Perahu

\begin{tabular}{|c|c|c|c|c|c|c|c|c|c|c|}
\hline \multirow{2}{*}{\multicolumn{2}{|c|}{ Titik ukur $\left({ }^{\circ} \mathrm{C}\right)$}} & \multicolumn{3}{|c|}{$\begin{array}{l}\text { Minggu, } \\
15 \text { Mei } 2016\end{array}$} & \multicolumn{3}{|c|}{$\begin{array}{c}\text { Selasa, } \\
24 \text { Mei } 2016\end{array}$} & \multicolumn{3}{|c|}{$\begin{array}{c}\text { Sabtu, } \\
\text { 25 Juni } 2016\end{array}$} \\
\hline & & Pagi & Siang & Sore & Pagi & Siang & Sore & Pagi & Siang & Sore \\
\hline \multirow[t]{3}{*}{ Segmen 1} & 1 & 32.7 & 34.4 & 33.7 & 32.5 & 33.2 & 33.1 & 32.4 & 33.8 & 33.4 \\
\hline & 2 & 33.8 & 34.5 & 33.7 & 32.6 & 33.4 & 33.1 & 32.6 & 33.4 & 33.3 \\
\hline & 3 & 32.4 & 33.8 & 33.5 & 32.3 & 33.0 & 32.8 & 32.2 & 33.5 & 32.4 \\
\hline \multirow[t]{3}{*}{ Segmen 2} & 1 & 33.1 & 34.2 & 33.5 & 32.2 & 33.4 & 33.3 & 32.5 & 33.1 & 33.0 \\
\hline & 2 & 33.3 & 34.8 & 33.9 & 32.4 & 33.5 & 33.3 & 32.4 & 33.5 & 33.3 \\
\hline & 3 & 31.5 & 33.6 & 33.5 & 32.1 & 33.2 & 32.9 & 32.1 & 33.2 & 32.2 \\
\hline \multirow[t]{3}{*}{ Segmen 3} & 1 & 32.5 & 33.8 & 32.5 & 30.8 & 33.1 & 32.8 & 32.1 & 32.9 & 32.7 \\
\hline & 2 & 31.5 & 33.1 & 32.7 & 31.2 & 33.3 & 33.1 & 31.2 & 33.3 & 33.1 \\
\hline & 3 & 31.3 & 33.0 & 33.1 & 30.6 & 33.1 & 32.9 & 32.0 & 33.1 & 32.5 \\
\hline \multirow[t]{3}{*}{ Segmen 4} & 1 & 32.8 & 32.8 & 33.2 & 32.7 & 32.9 & 32.7 & 32.6 & 32.7 & 32.8 \\
\hline & 2 & 33.6 & 33.9 & 33.1 & 33.1 & 33.0 & 33.0 & 33.1 & 33.0 & 33.0 \\
\hline & 3 & 31.3 & 33.5 & 32.9 & 32.4 & 32.7 & 32.7 & 32.1 & 32.4 & 32.6 \\
\hline \multicolumn{2}{|c|}{ Luar tapak } & 33.1 & 35.1 & 33.9 & 33.2 & 34.9 & 34.2 & 33 & 35.2 & 34.5 \\
\hline
\end{tabular}

Ket: 1: Di atas rumput tanpa naungan

2: Di atas perkerasan tanpa naungan

3: Di atas rumput di bawah naungan pohon 
Lampiran 14 Hasil pengukuran suhu perhari di Taman Mataram

\begin{tabular}{|c|c|c|c|c|c|c|c|c|c|c|}
\hline \multirow{2}{*}{\multicolumn{2}{|c|}{ Titik ukur $\left({ }^{\circ} \mathrm{C}\right)$}} & \multicolumn{3}{|c|}{$\begin{array}{c}\text { Rabu, } \\
18 \text { Mei } 2016\end{array}$} & \multicolumn{3}{|c|}{$\begin{array}{l}\text { Minggu, } \\
\text { 26 Juni } 2016\end{array}$} & \multicolumn{3}{|c|}{$\begin{array}{l}\text { Senin, } \\
\text { 27 Juni } 2016\end{array}$} \\
\hline & & Pagi & Siang & Sore & Pagi & Siang & Sore & Pagi & Siang & Sore \\
\hline \multirow[t]{3}{*}{ Segmen 1} & 1 & 30.6 & 31.8 & 30.4 & 30.7 & 31.7 & 30.5 & 30.6 & 31.8 & 30.3 \\
\hline & 2 & 31.7 & 32.3 & 31.2 & 31.8 & 32.5 & 32.4 & 31.7 & 31.9 & 32.4 \\
\hline & 3 & 29.3 & 31.3 & 30.2 & 28.9 & 31.4 & 31.4 & 29.5 & 31.4 & 31.4 \\
\hline \multirow[t]{3}{*}{ Segmen 2} & 1 & 30.4 & 30.5 & 31.0 & 30.3 & 30.5 & 31.1 & 30.5 & 30.6 & 31.3 \\
\hline & 2 & 30.8 & 31.2 & 31.0 & 32.6 & 32.1 & 31.7 & 31.0 & 32.0 & 31.7 \\
\hline & 3 & 30.9 & 30.9 & 30.8 & 30.3 & 30.7 & 30.6 & 30.2 & 30.6 & 30.6 \\
\hline \multirow{3}{*}{ Segmen 3} & 1 & 31.8 & 31.5 & 31.1 & 30.7 & 31.2 & 31.2 & 30.9 & 31.3 & 31.2 \\
\hline & 2 & 31.0 & 31.4 & 31.3 & 31.3 & 31.0 & 31.1 & 31.0 & 30.9 & 31.2 \\
\hline & 3 & 30.9 & 30.7 & 30.9 & 29.7 & 30.4 & 30.4 & 29.4 & 30.2 & 30.2 \\
\hline \multirow{3}{*}{ Segmen 4} & 1 & 32.0 & 32.1 & 32.0 & 31.8 & 31.9 & 31.8 & 31.8 & 32.0 & 31.7 \\
\hline & 2 & 32.0 & 31.9 & 30.9 & 32.0 & 31.4 & 31.4 & 31.6 & 31.1 & 31.1 \\
\hline & 3 & 31.0 & 30.7 & 30.7 & 30.4 & 30.1 & 30.0 & 30.3 & 30.3 & 30.2 \\
\hline Luar tapak & & 31.8 & 31.5 & 31.7 & 32.0 & 31.6 & 31.8 & 31.9 & 31.4 & 31.7 \\
\hline
\end{tabular}

Ket: 1 i : Di atas rumput tanpa naungan

2: Di atas perkerasan tanpa naungan

Di atas rumput di bawah naungan pohon

Lampiran 15 Hasil pengukuran kelembaban udara perhari di Taman Ayodya

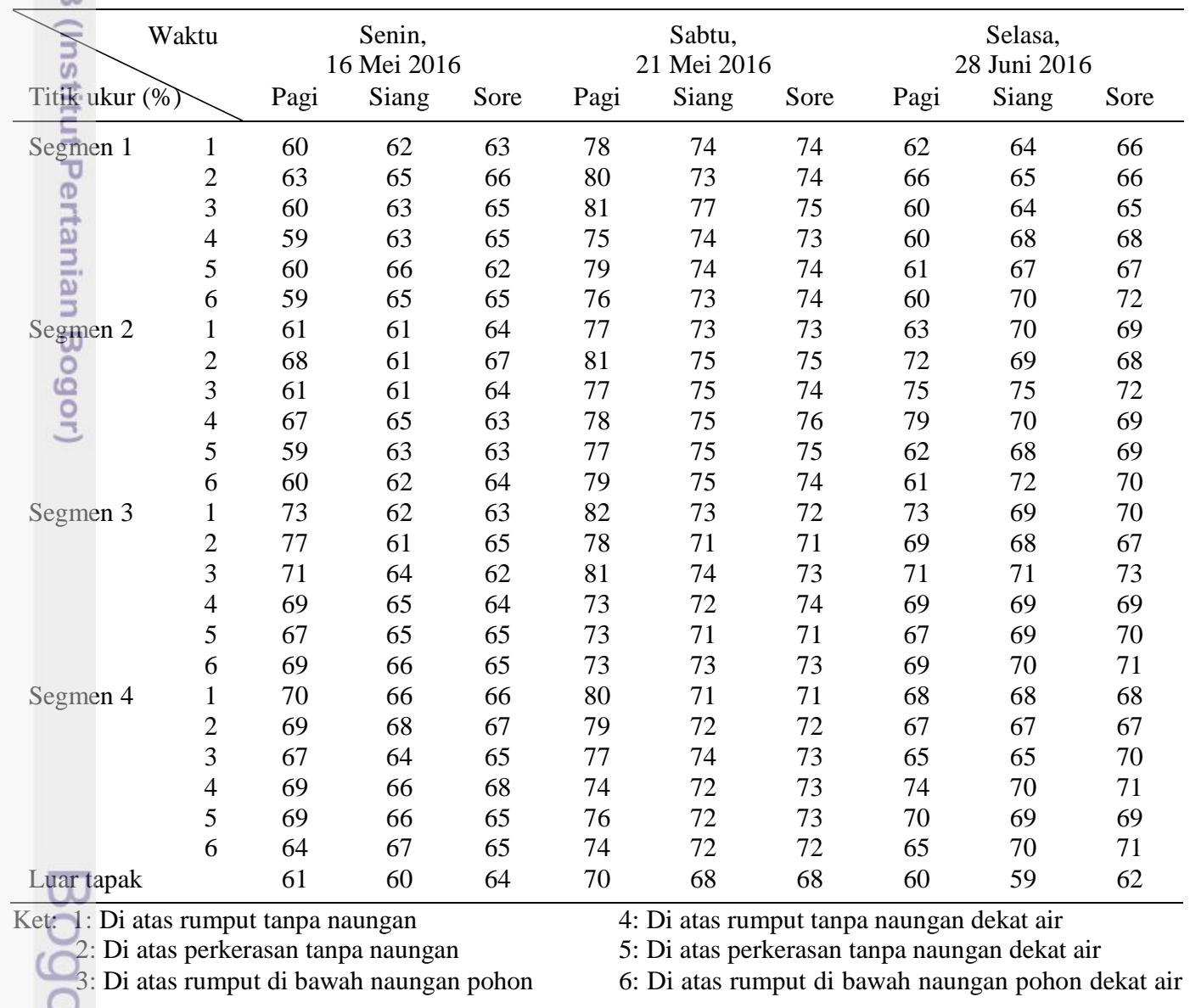



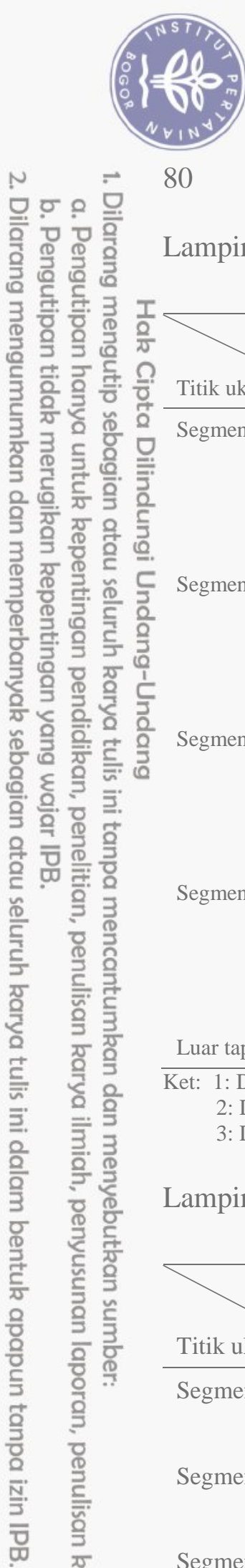

$\rightarrow \quad 80$

Lampiran 16 Hasil pengukuran kelembaban udara perhari di Taman Martha Tiahahu

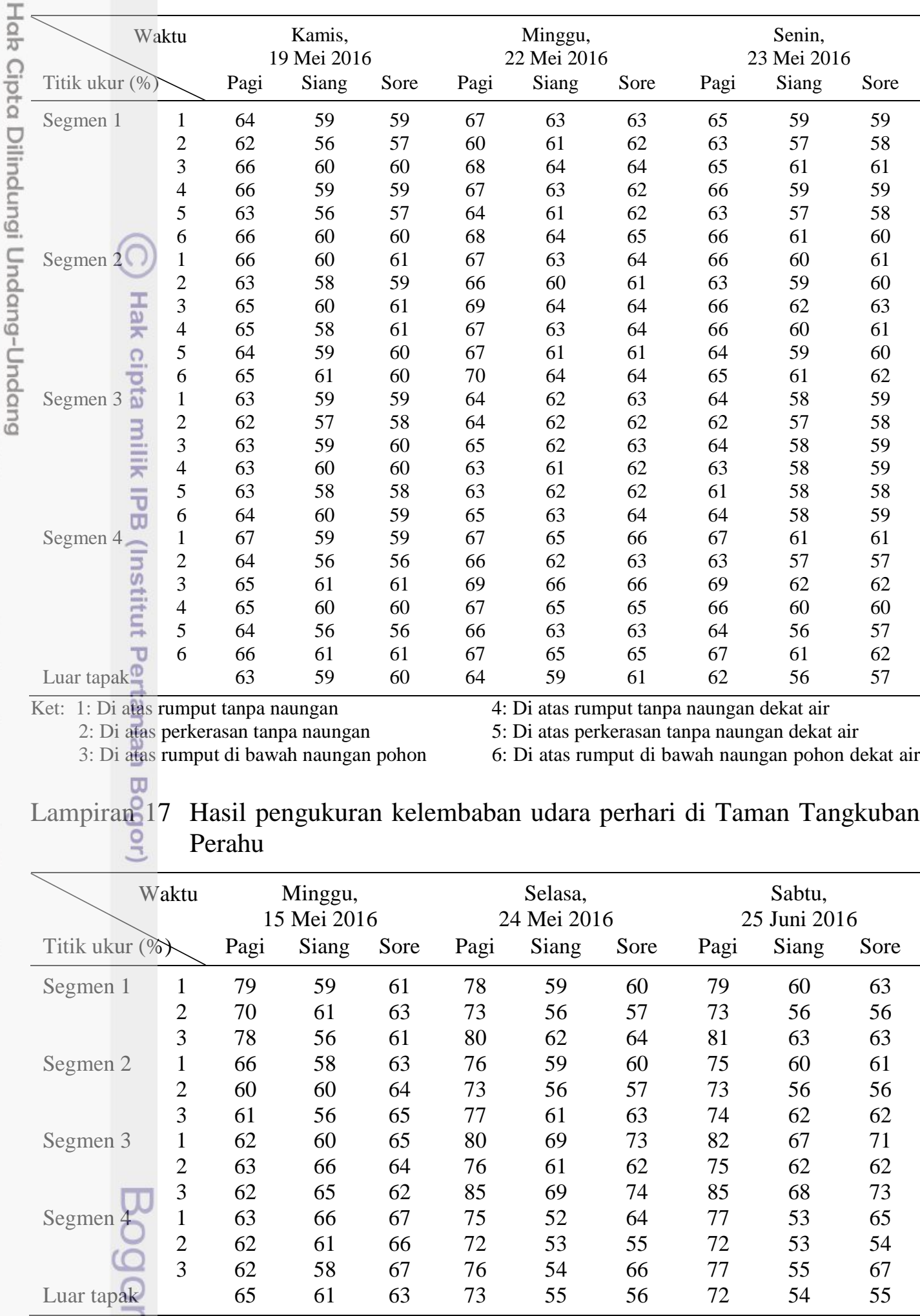

Ket: 1 : Di atas rumput tanpa naungan

2: Di atas perkerasan tanpa naungan

3: Di atas rumput di bawah naungan pohon 
Lampiran 18 Hasil pengukuran kelembaban udara perhari di Taman Mataram

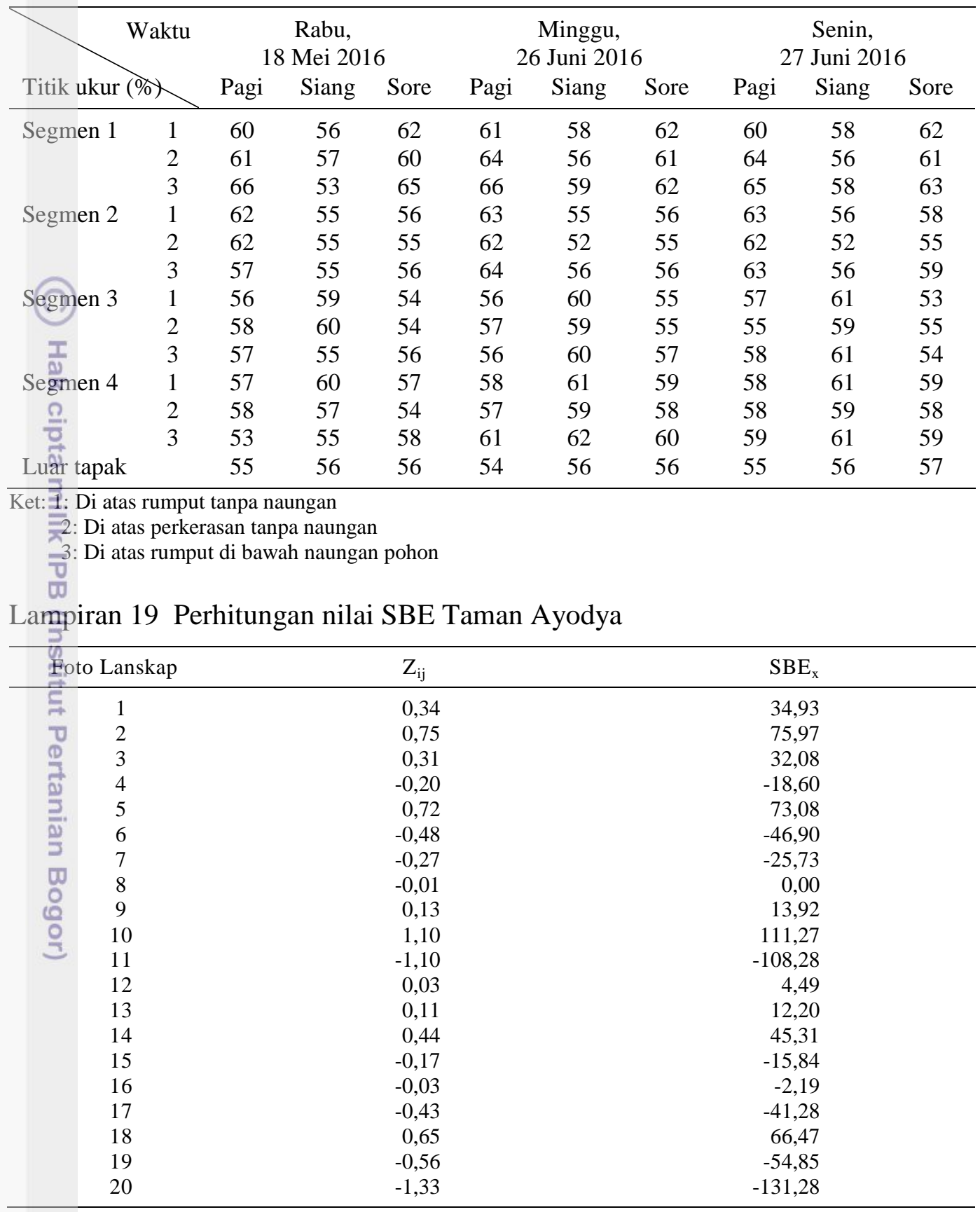

Lampiran 20 Perhitungan nilai SBE Taman Martha Tiahahu

\begin{tabular}{clll}
\hline Foto Lanskap & $\mathrm{Z}_{\mathrm{ij}}$ & $\mathrm{SBE}_{\mathrm{x}}$ \\
\hline $\mathrm{C}$ & 1 & 0,68 & 63,66 \\
$\mathrm{C}$ & 2 & 0,71 & 66,64 \\
$\mathrm{O}$ & 3 & 0,27 & 22,76 \\
$\mathrm{~T}$ & 4 & 0,36 & 31,17 \\
$\mathrm{D}$ & 5 & 0,31 & 26,14 \\
$\mathrm{C}$ & 7 & 0,85 & 80,63 \\
\hline & 8 & 0,74 & 69,39 \\
\hline
\end{tabular}




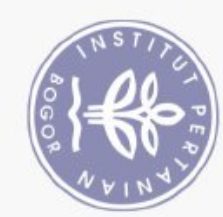

Lampiran 19 Perhitungan nilai SBE Taman Martha Tiahahu (lanjutan)

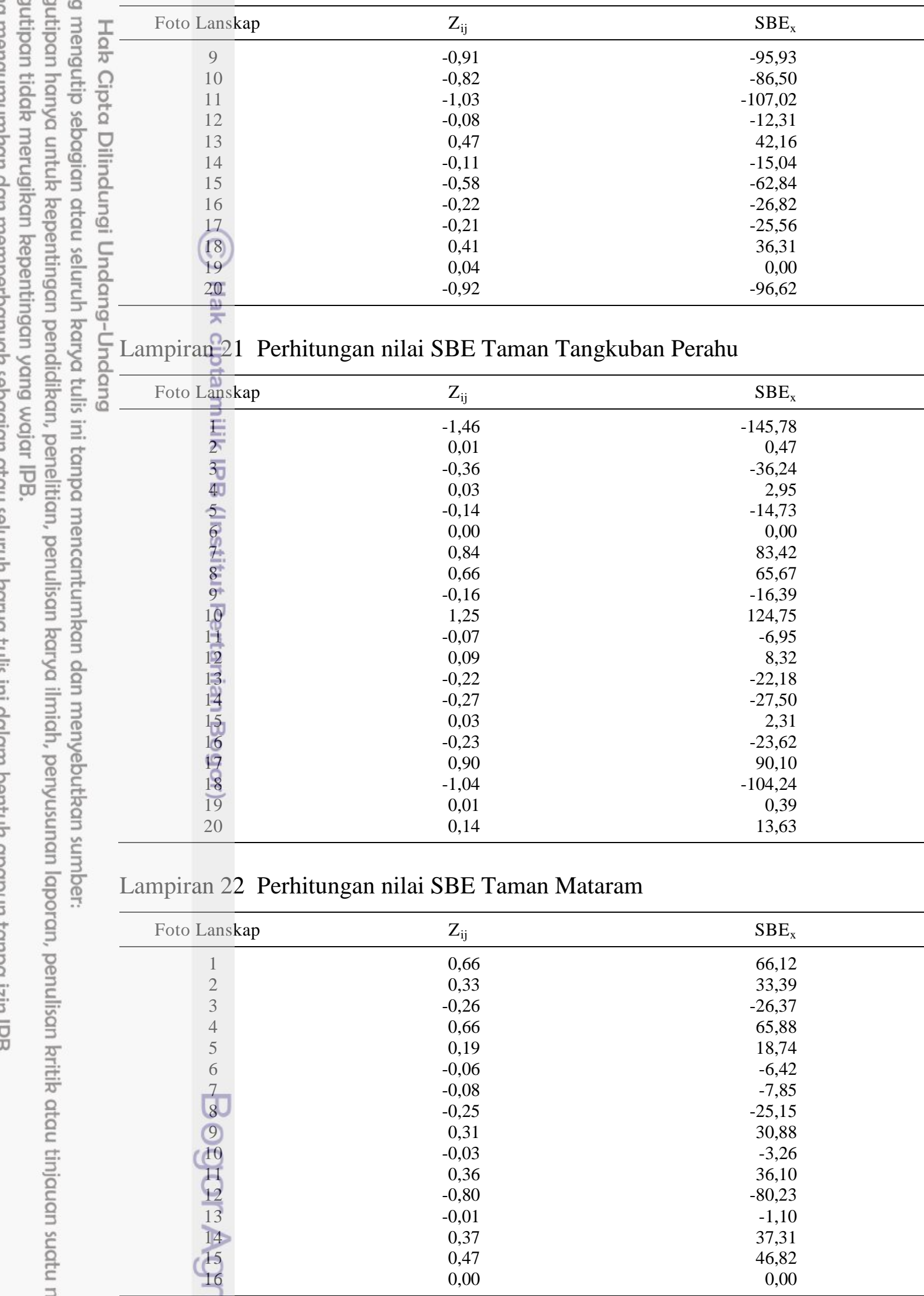


Lampiran 21 Perhitungan nilai SBE Taman Mataram (lanjutan)

\begin{tabular}{crr}
\hline Foto Lanskap & \multicolumn{1}{c}{$\mathrm{Z}_{\mathrm{ij}}$} & $\mathrm{SBE}_{\mathrm{x}}$ \\
\hline 17 & $-1,13$ & $-112,82$ \\
18 & 0,13 & 13,04 \\
19 & $-0,09$ & $-9,05$ \\
20 & $-0,78$ & $-77,71$ \\
\hline
\end{tabular}

Lampiran 23 Foto lanskap Taman Ayodya

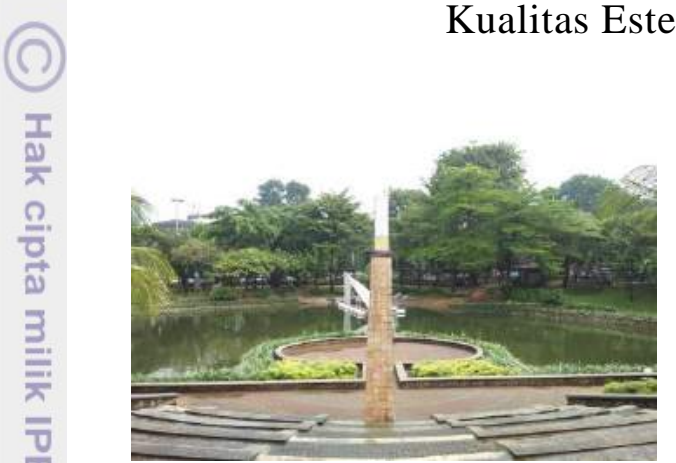

Lanskap $1(\mathrm{SBE}=34,93)$

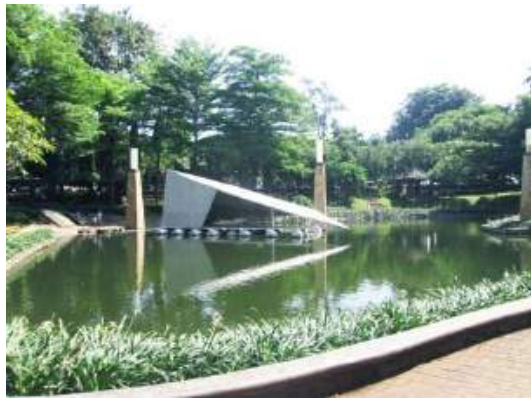

Lanskap 3(SBE=32,08)

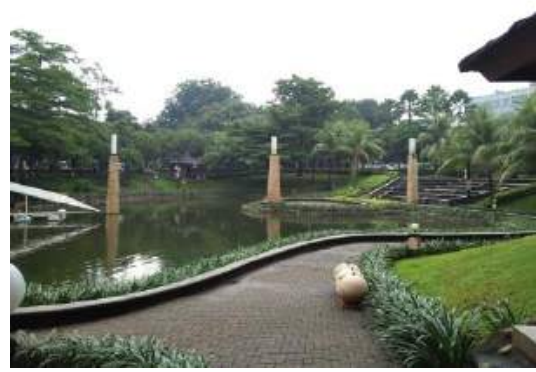

Lanskap 10(SBE=111,27)

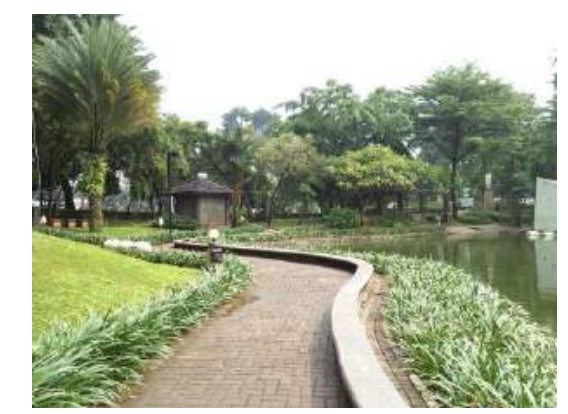

Lanskap 2(SBE $=75,97)$

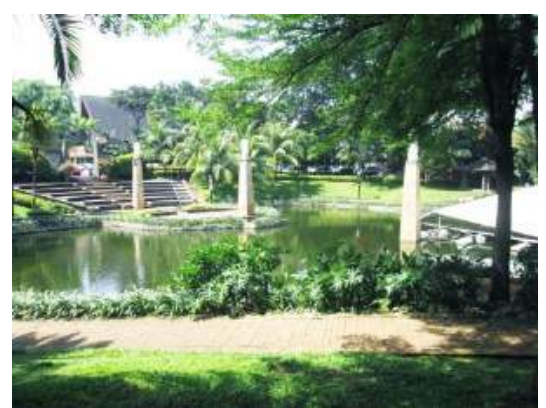

Lanskap 5(SBE=73,08)

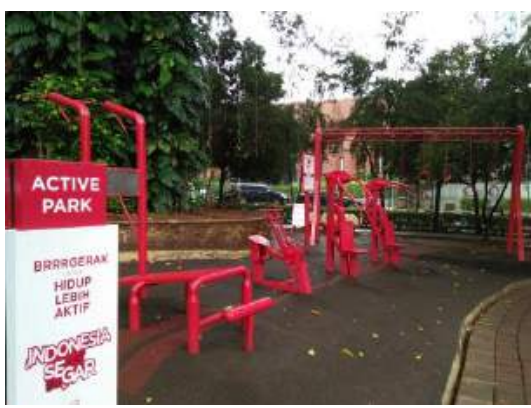

Lanskap 14(SBE=45,31) 

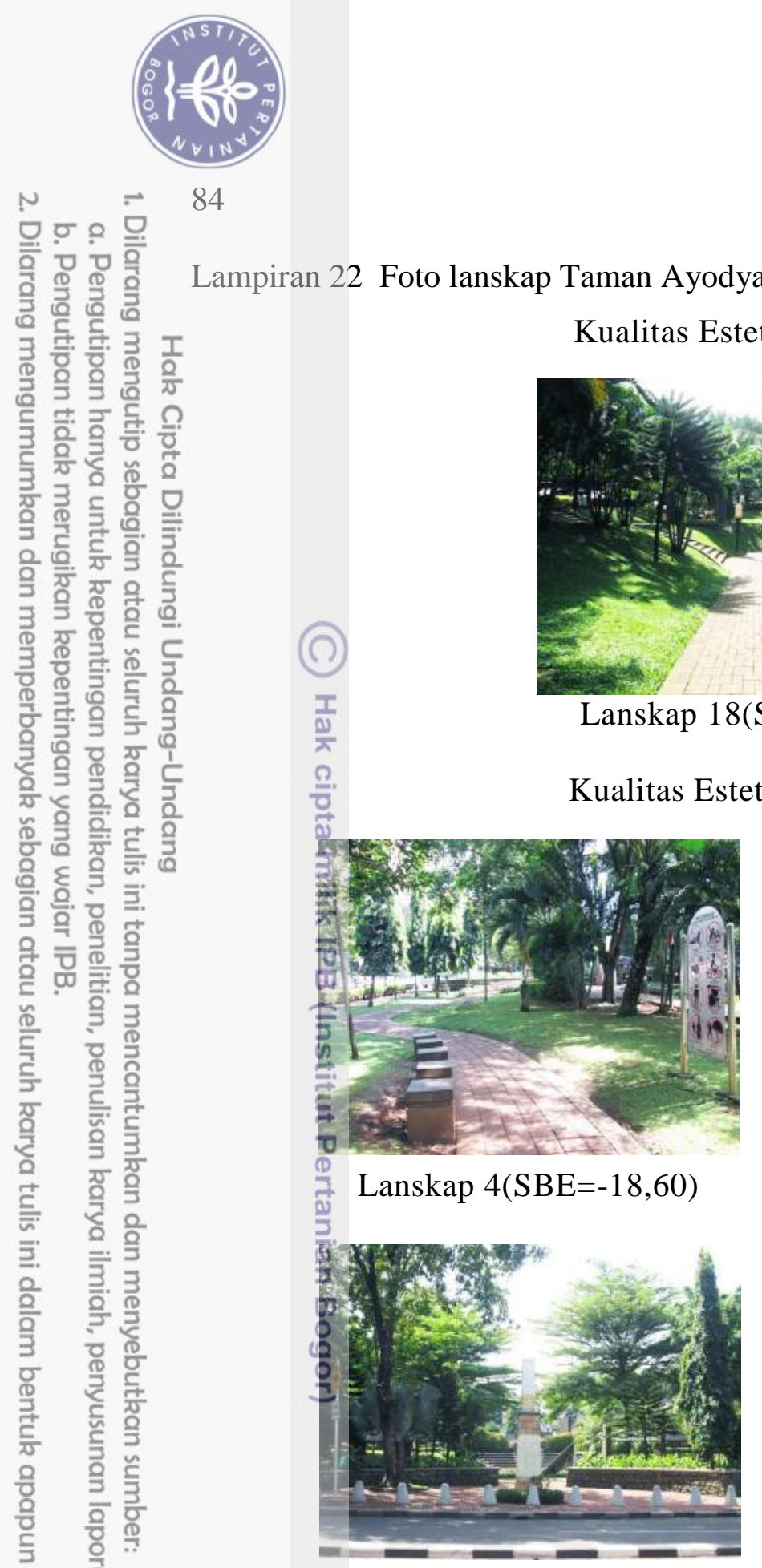

Lanskap $9(\mathrm{SBE}=13,92)$
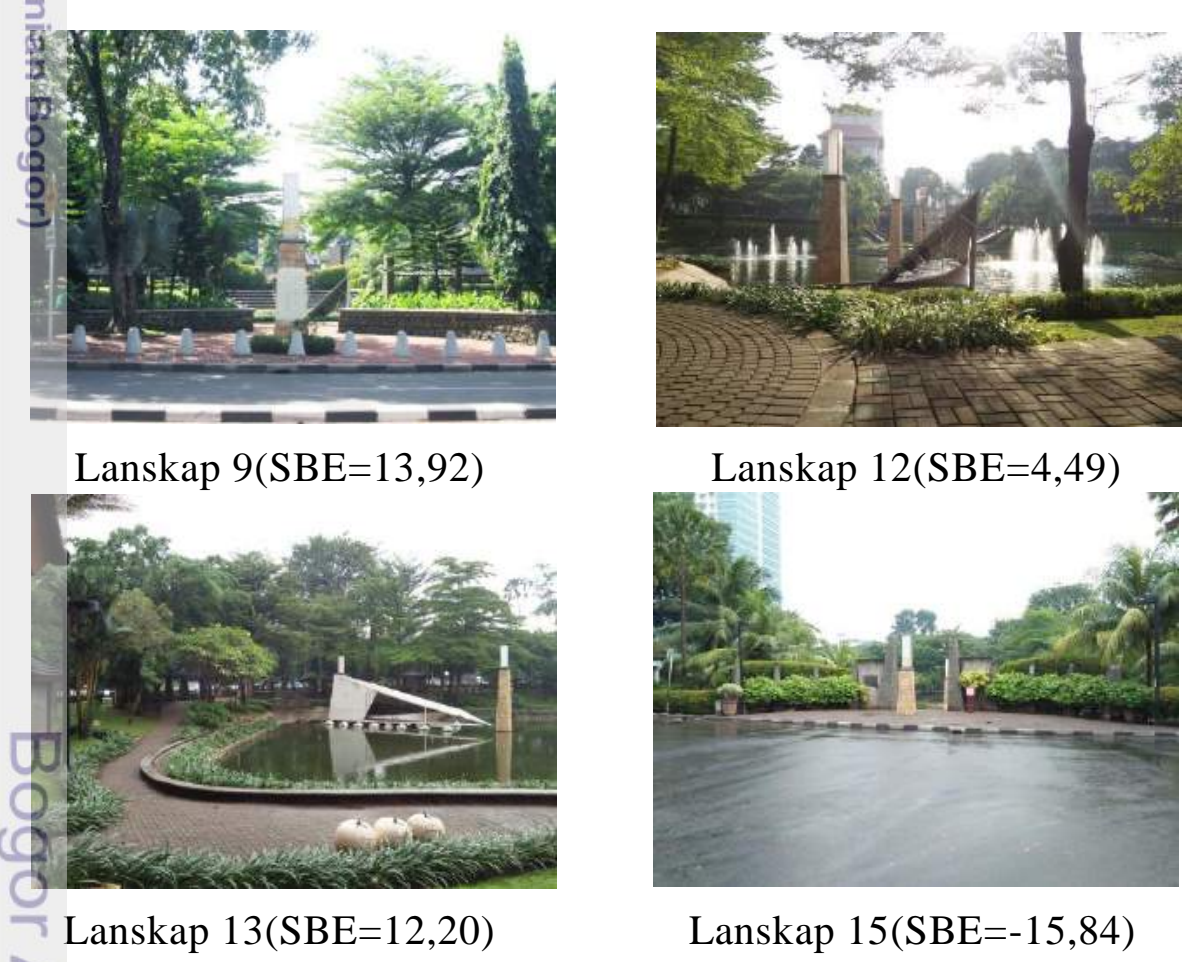

Lanskap 15(SBE=-15,84)

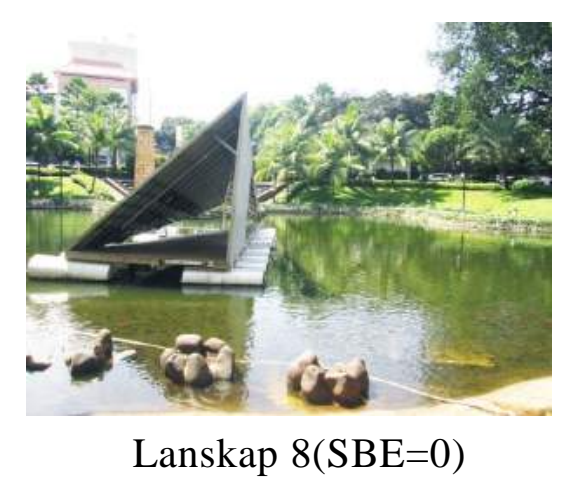


Lampiran 22 Foto lanskap Taman Ayodya (lanjutan)

을 을

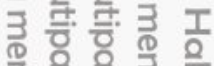

Kualitas Estetika Sedang

范宁高

응형

옥 꼭 을 을

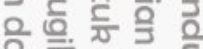

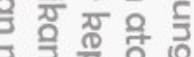

ग

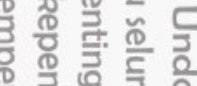

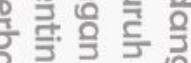

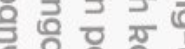

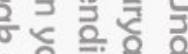

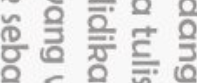

ह 응

을 윽윰

웅 孟空

을 족

రำ

를

을

징

ㄷํㅇ 응

言

은 일

쥬

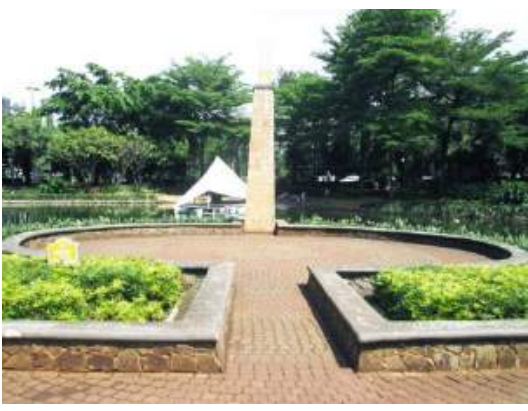

Lanskap 16(SBE=-2,19)

Kualitas Estetika Rendah

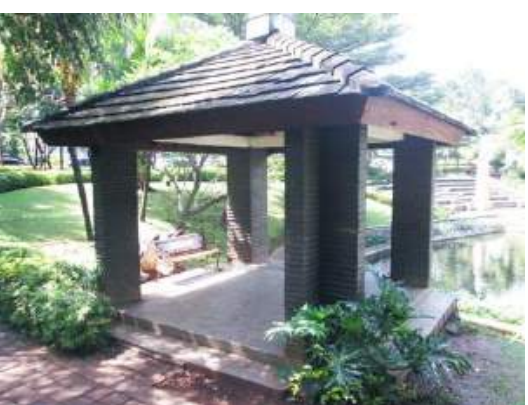

Lanskap 6(SBE=-46,90)

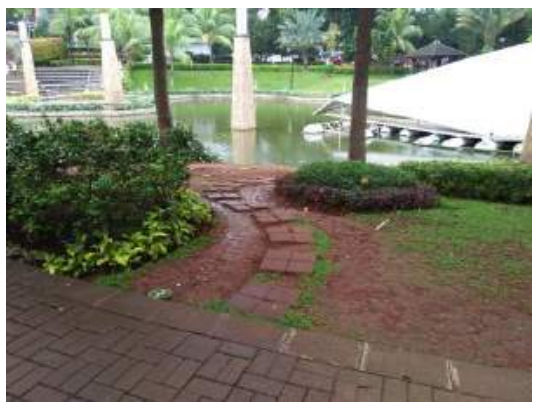

Lanskap 11(SBE=-108,28)

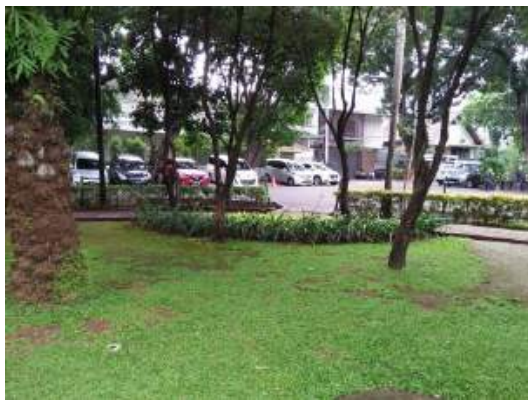

Lanskap 19(SBE=-54,85)

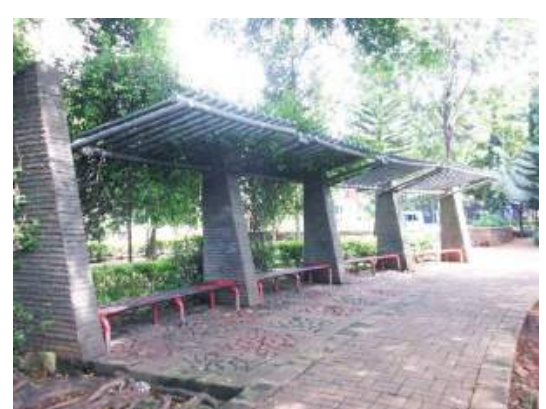

Lanskap 7(SBE=25,73)

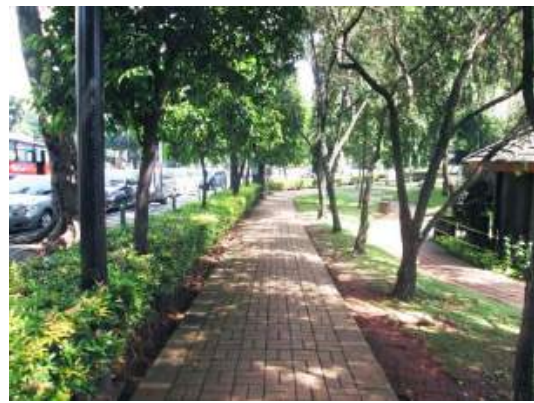

Lanskap 17(SBE=-41,28)

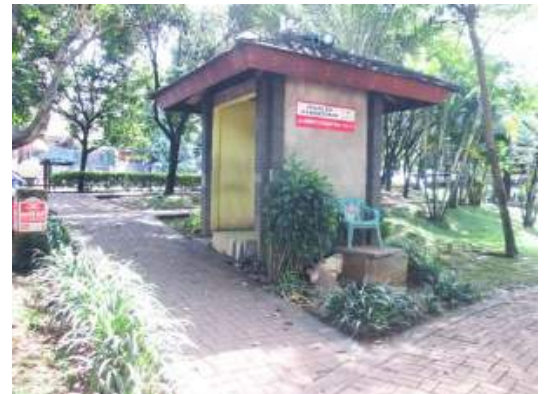

Lanskap 20(SBE=-131,28) 


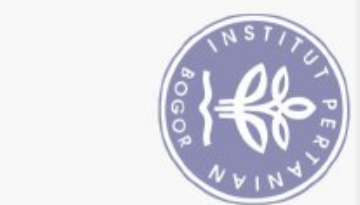

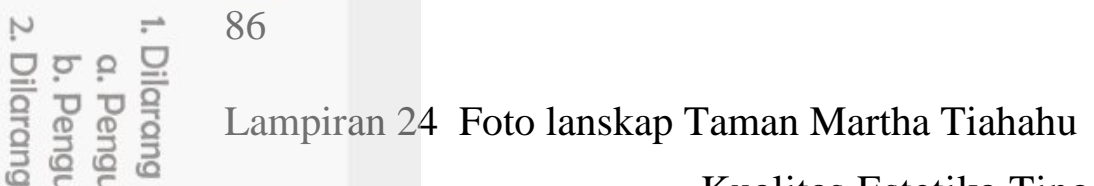

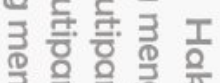

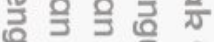$$
\text { 言 흥 흘 음 }
$$

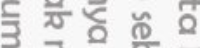$$
\text { 을 곡 을 을. }
$$$$
\text { 은 흘. 동읭 }
$$

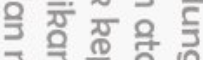$$
\text { उ }
$$

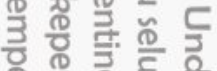

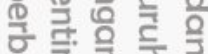$$
\text { 을 융 잉 }
$$

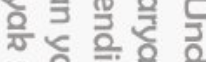

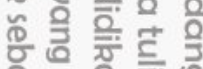

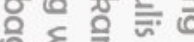

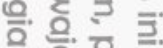$$
\text { 익요 }
$$$$
\text { 웅 } \overline{\mathrm{D}} \text { 을 }
$$$$
\text { 要 }
$$$$
\text { 흘 } \frac{2}{3}
$$$$
\text { ชั }
$$$$
\text { 을 }
$$$$
\text { 을 亭 }
$$$$
\text { गू }
$$$$
\text { 을 }
$$$$
\text { 동응 }
$$$$
\text { 흘 }
$$$$
\text { 흘 공 }
$$

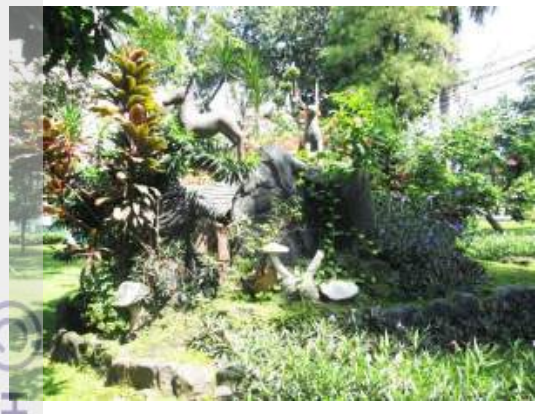

Lanskap 1(SBE=63,66)

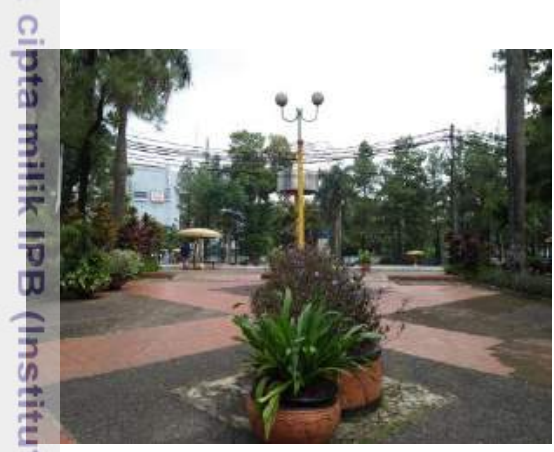

Lanskap 3(SBE=22,76)

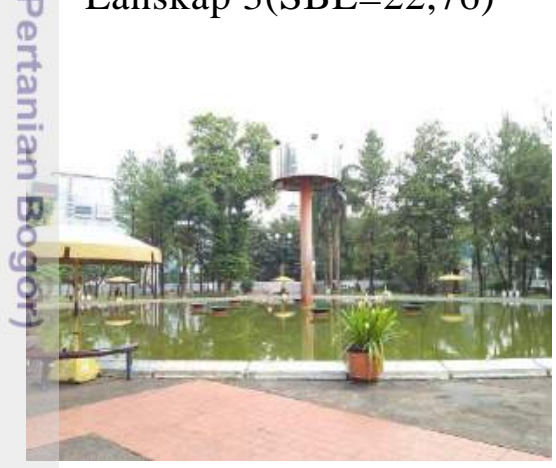

Lanskap 5(SBE=26,14)

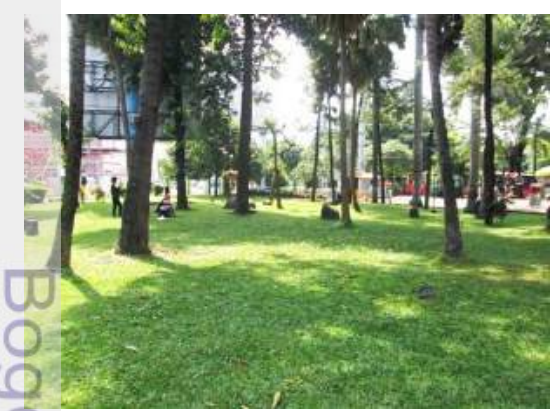

Lanskap 7(SBE=69,39)

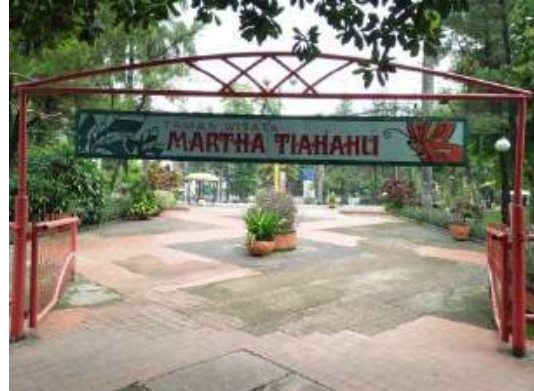

Lanskap 2(SBE=66,64)

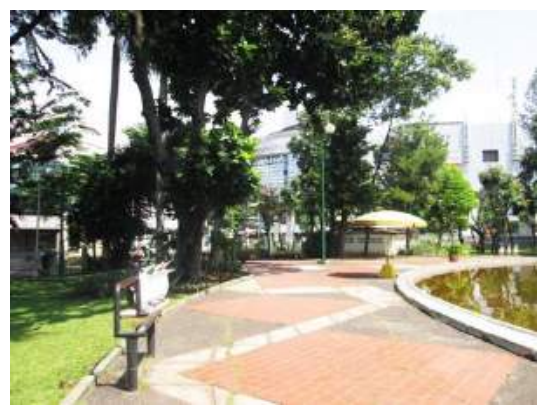

Lanskap 4(SBE=31,17)

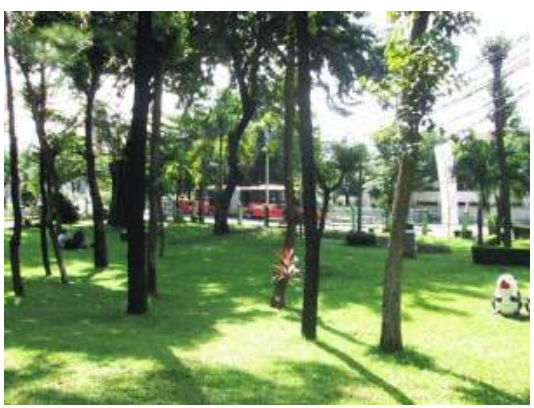

Lanskap 6(SBE=80,63)

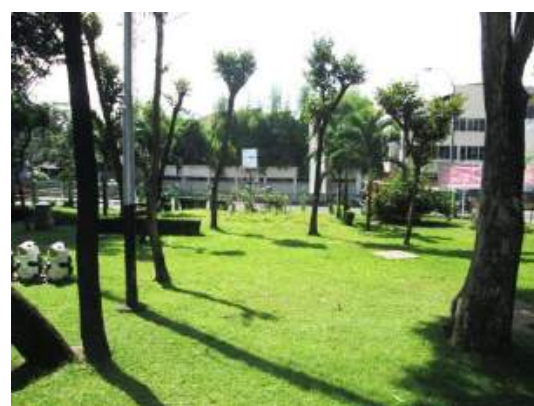

Lanskap 13(SBE=42,16) 


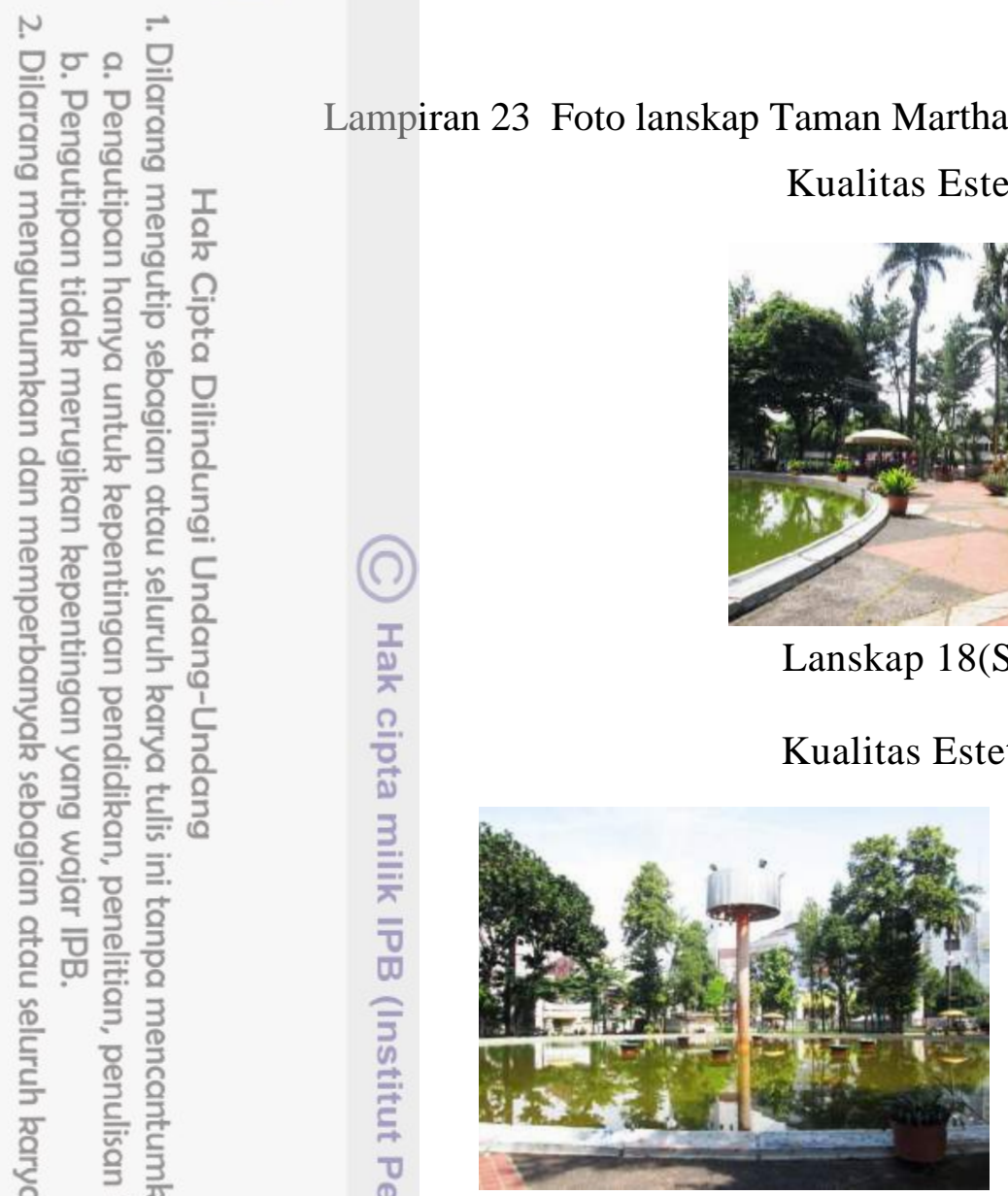

Lanskap $8(\mathrm{SBE}=0,67)$

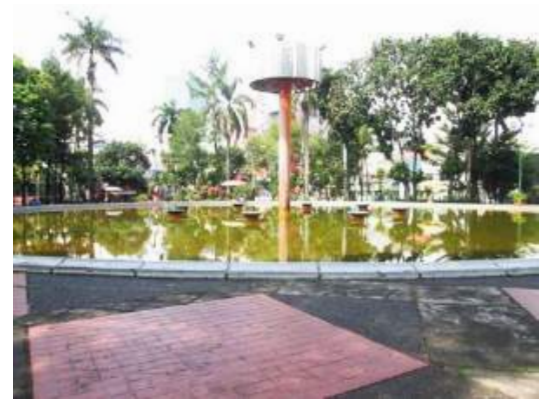

Lanskap 14(SBE=-15,04)

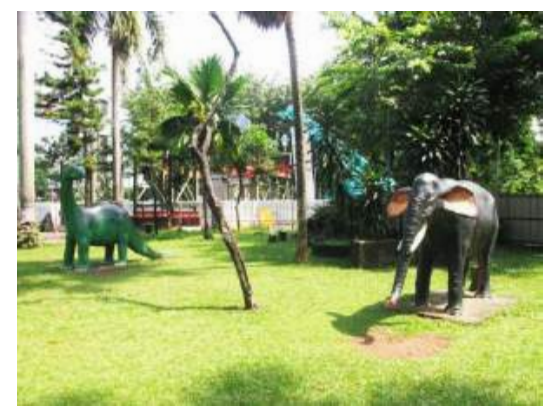

Lanskap 12(SBE=-12,31)

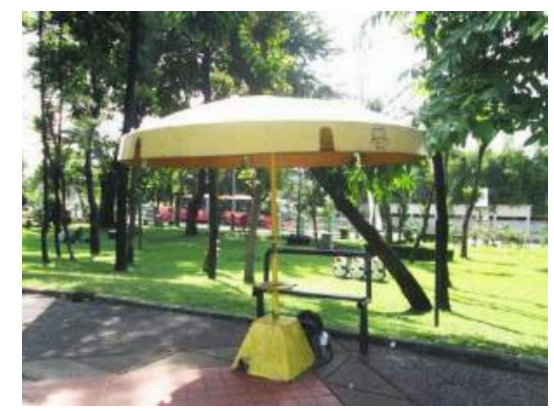

Lanskap 19(SBE=0)

Kualitas Estetika Rendah

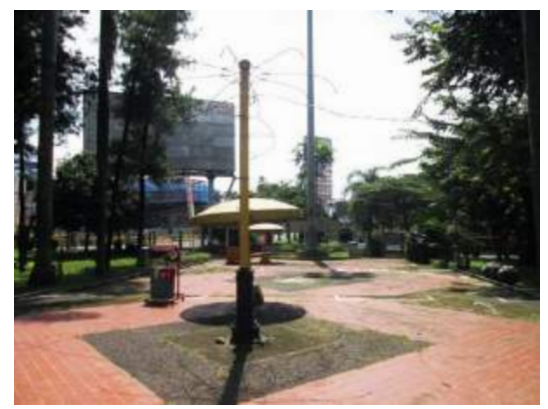

Lanskap 9(SBE=-95,93)

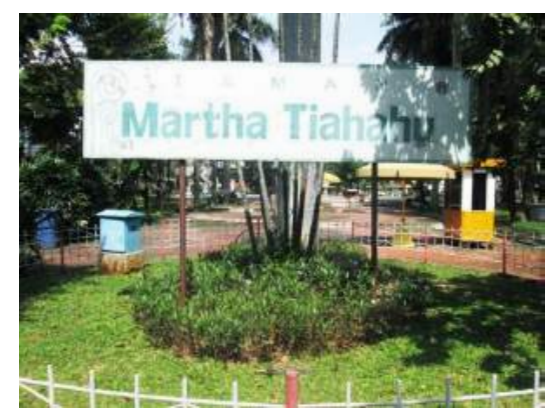

Lanskap 10(SBE=-86,50) 


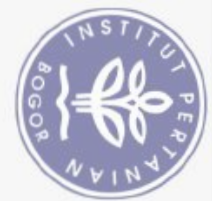

88

Lampiran 23 Foto lanskap Taman Martha Tiahahu (lanjutan)

Kualitas Estetika Rendah

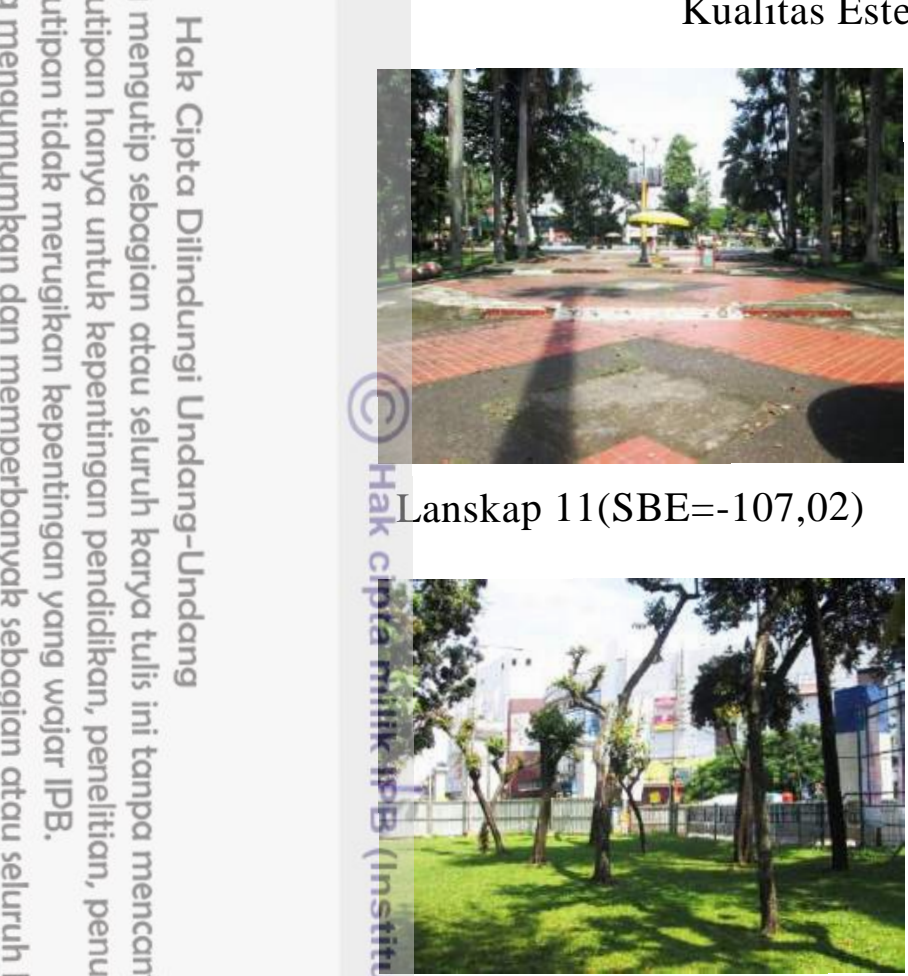

Lanskap 16(SBE=-26,82)

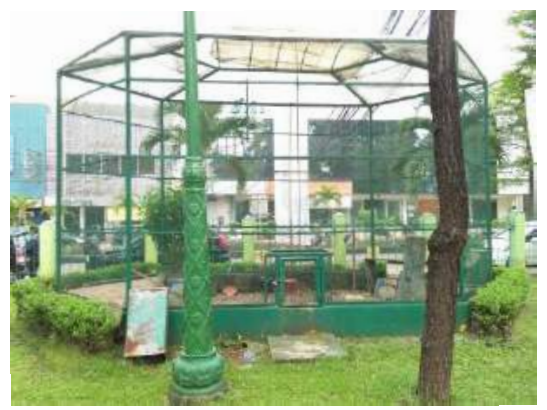

Lanskap 15(SBE=-62,84)

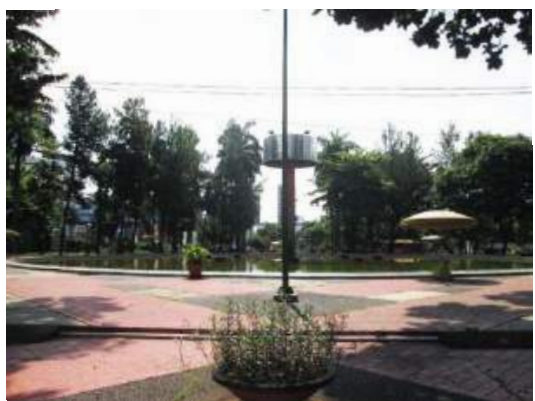

Lanskap 17(SBE=-25,56)

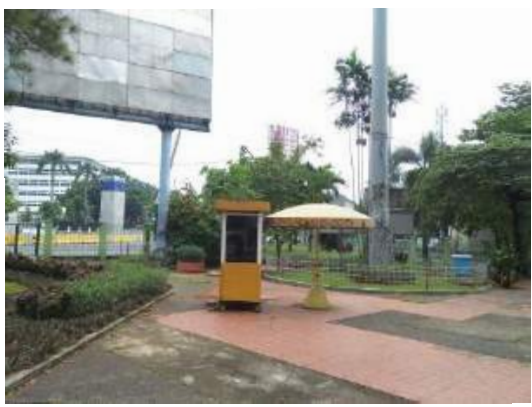

Lanskap 20(SBE=-96,62)

Lampiran 25 Foto lanskap Taman Tangkuban Perahu

Kualitas Estetika Tinggi

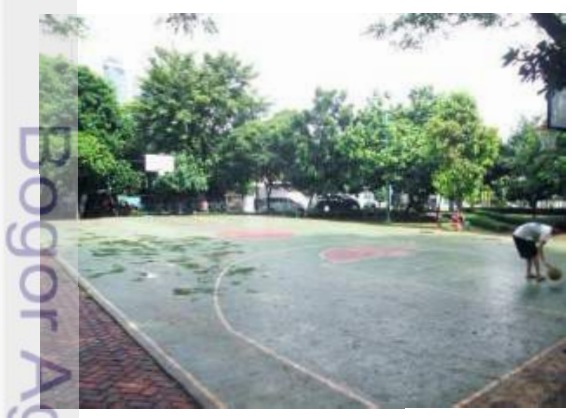

Lanskap 7(SBE=83,42)

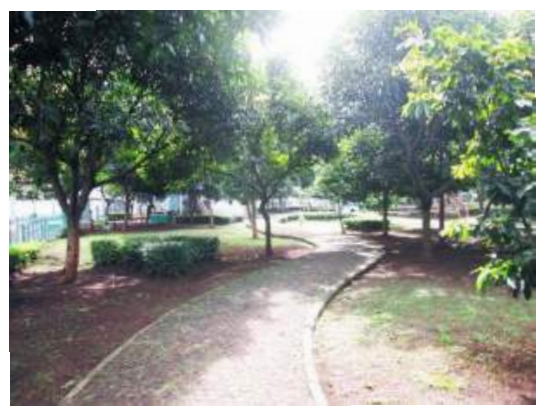

Lanskap $8(\mathrm{SBE}=65,67)$ 


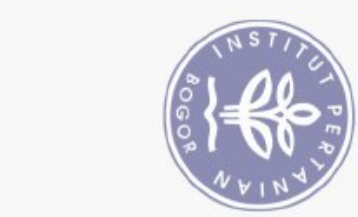

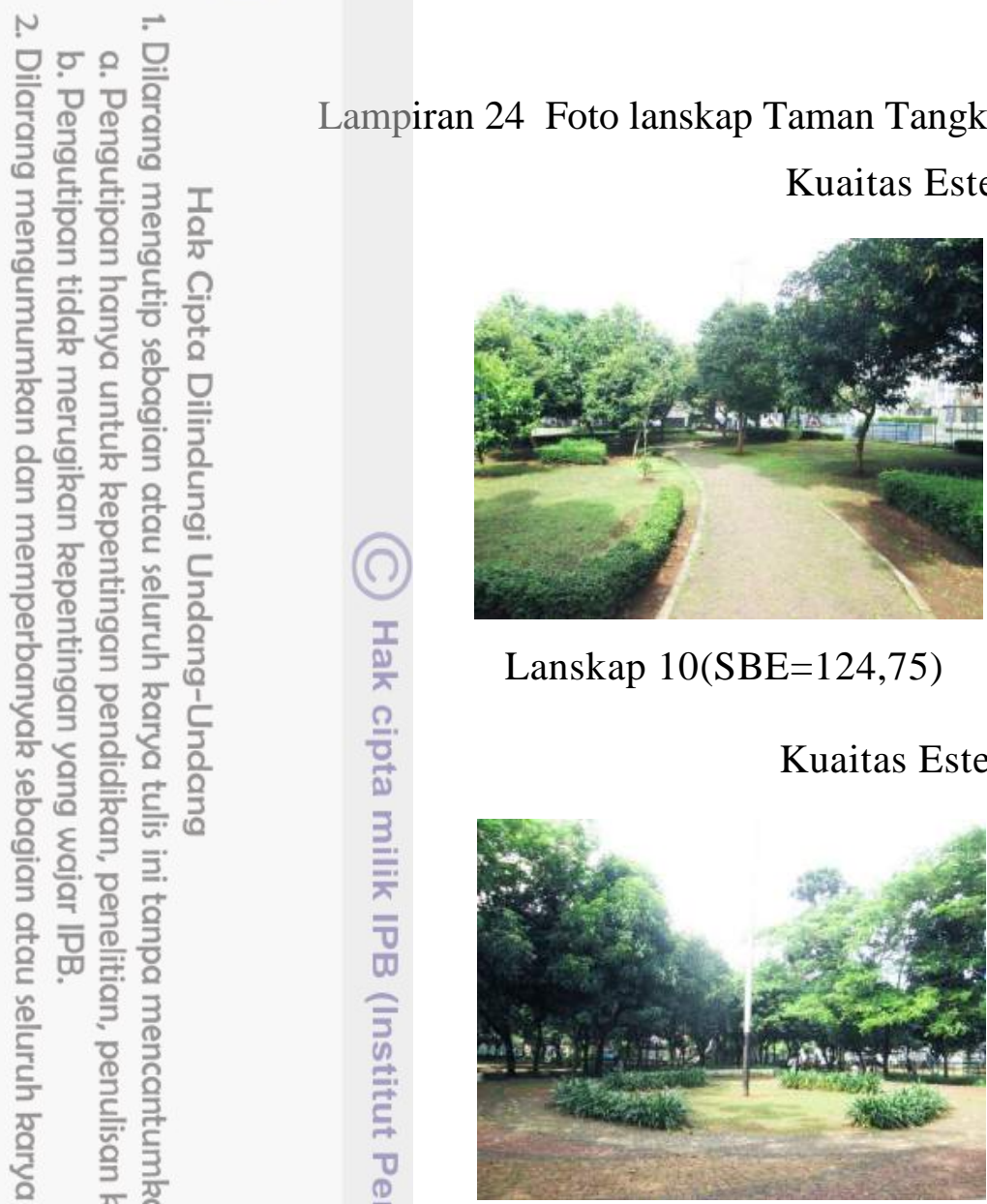

Lanskap 2(SBE=0,47)

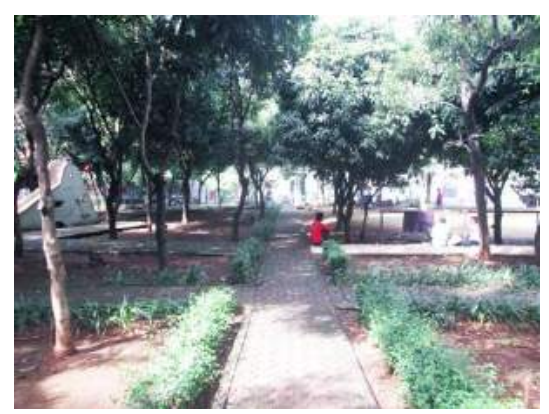

Lanskap 5(SBE=-14,73)

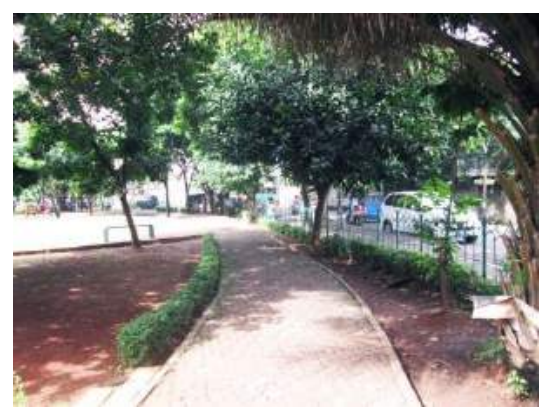

Lanskap $9(\mathrm{SBE}=-16,39)$

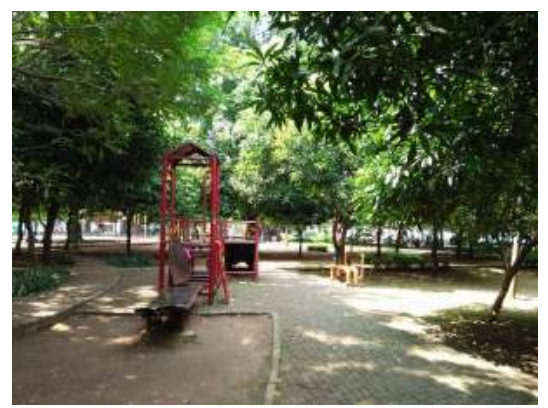

Lanskap 17(SBE=90,10)

uban Perahu (lanjutan)

ka Tinggi 


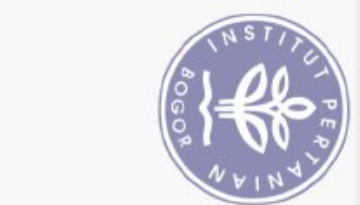

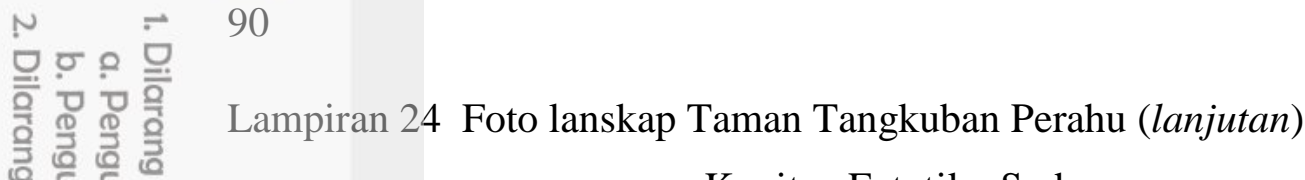

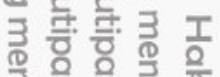

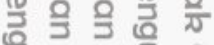$$
\text { 言 흥 흘 음 }
$$

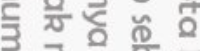

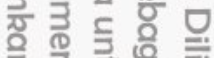

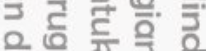$$
\text { 을 ग0 }
$$

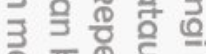

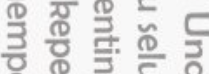$$
\text { 음을을 을 }
$$

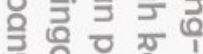$$
\text { 은올 }
$$$$
\text { 능응 }
$$

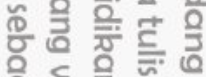$$
\text { 흥 है }
$$$$
\text { 윽 유 }
$$$$
\text { 웅 꿀을 음 }
$$$$
\text { 列 }
$$

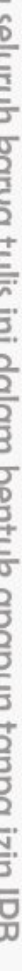$$
\text { 울 }
$$$$
\text { 유 을 }
$$$$
\text { 를 }
$$$$
\text { 을 }
$$$$
\text { 政 }
$$$$
\text { 익 }
$$$$
\text { ㄷㅇㅇ 응 }
$$$$
\text { 을 }
$$$$
\text { 공 }
$$

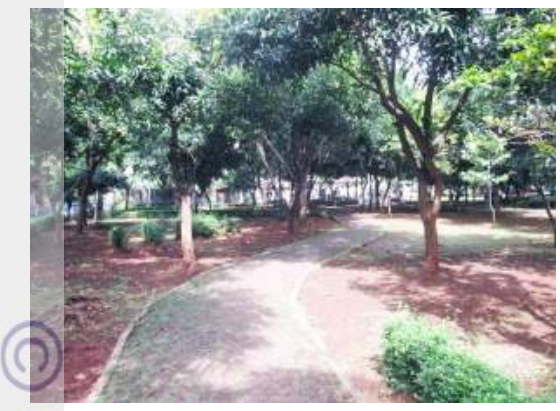$$
\text { 플 Lanskap } 12(\mathrm{SBE}=8,32)
$$

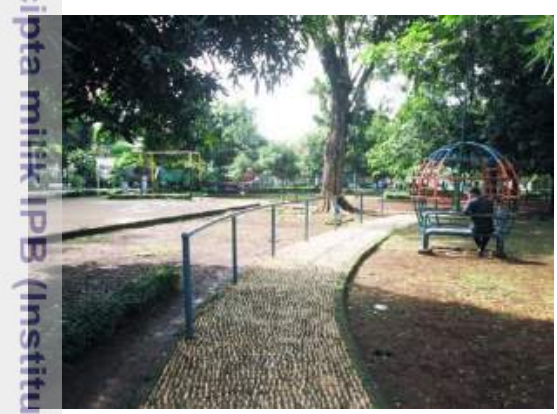

Lanskap 19(SBE=0,39)

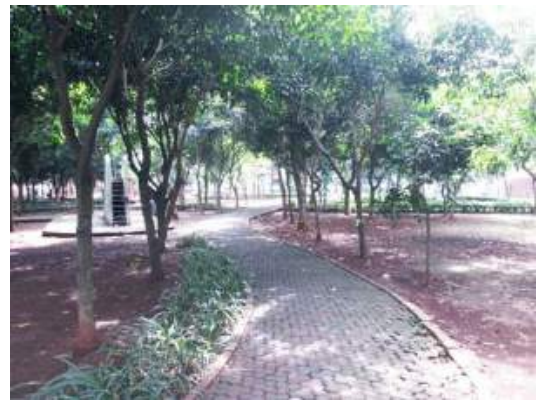

Lanskap 15(SBE=2,31)

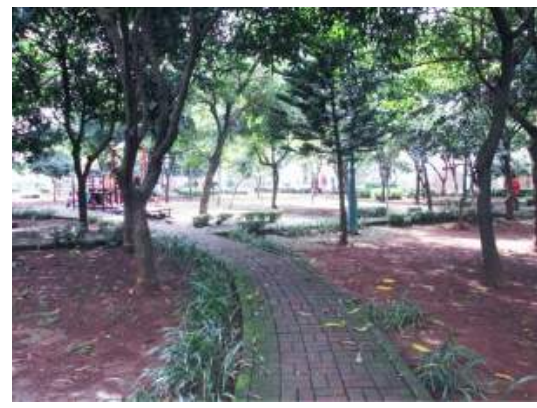

Lanskap 20(SBE=13,63)

Kualitas Estetika Rendah

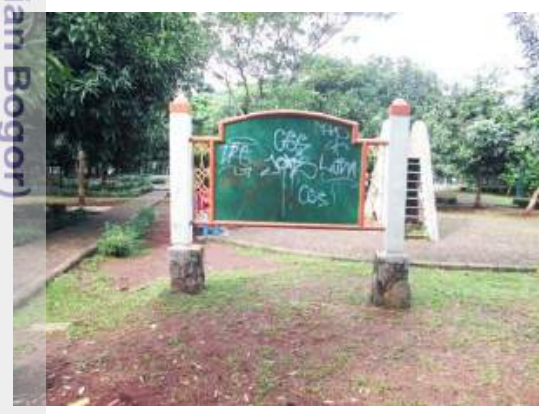

Lanskap 1(SBE=-145,78)

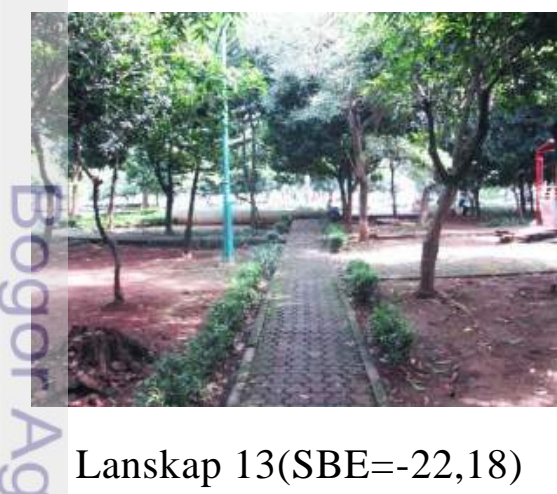

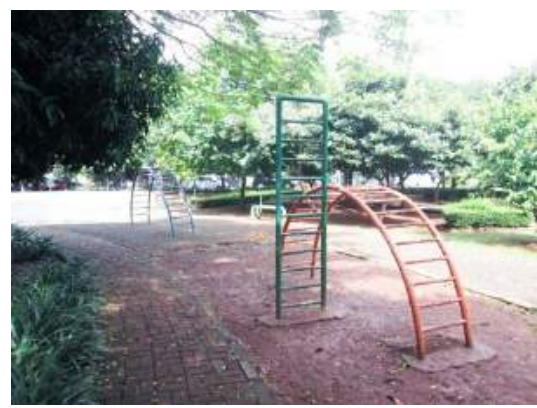

Lanskap 3(SBE=-36,24)

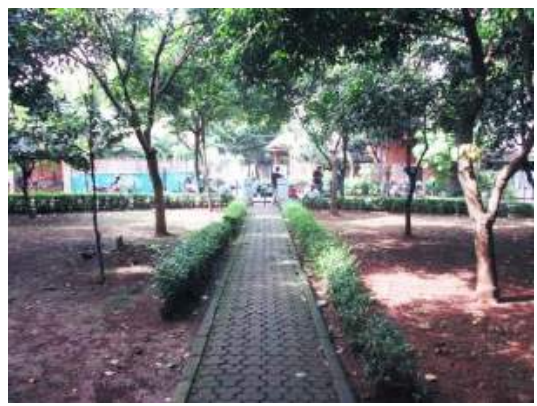

Lanskap 14(SBE=-27,50) 


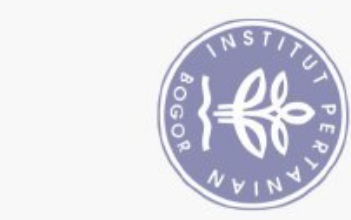

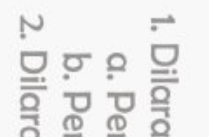

옹혀을

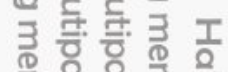

号을 을 응

들 흥흥 응

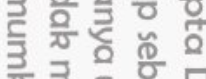

을 콕 을. 을.

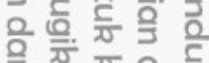

引옥융 웅 을

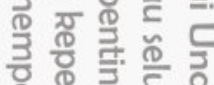

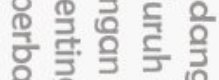

응 장 인

원들 응

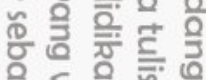

음. ह ฏ

을을 뭉

웅 모를 을

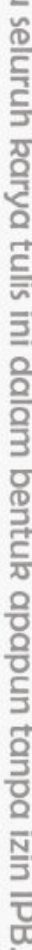

을 $\frac{2}{3}$

(อ)

$\frac{T}{\frac{1}{\pi}}$ ก

Lanskap 16(SBE=-23,62)

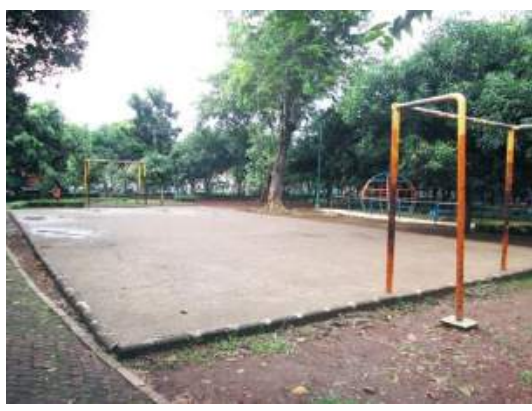

Lampiran 24 Foto lanskap Taman Tangkuban Perahu (lanjutan)

Kuaitas Estetika Rendah

Lañpiran 26 Foto lanskap Taman Mataram

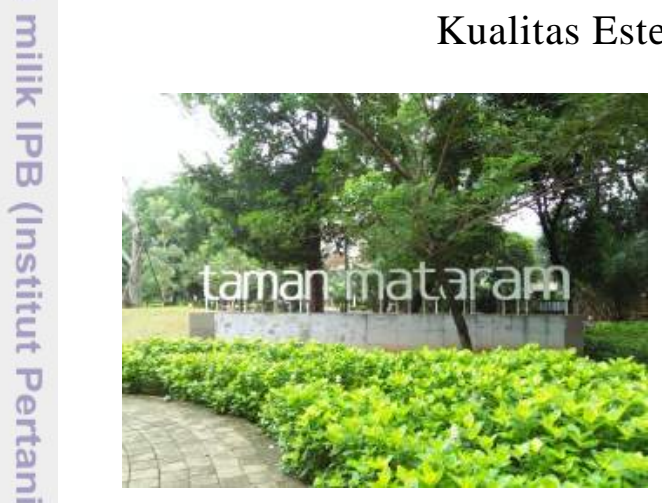

Lanskap 1(SBE=66,12)

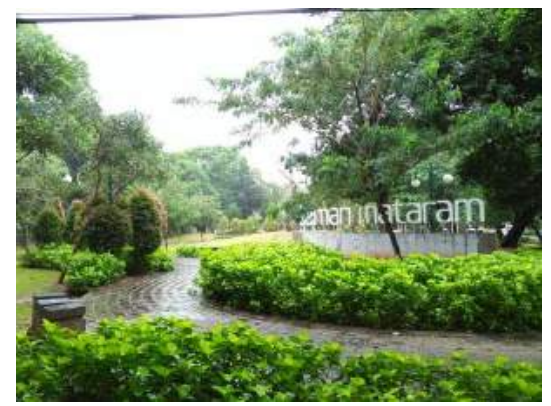

Lanskap 4(SBE=65,88)

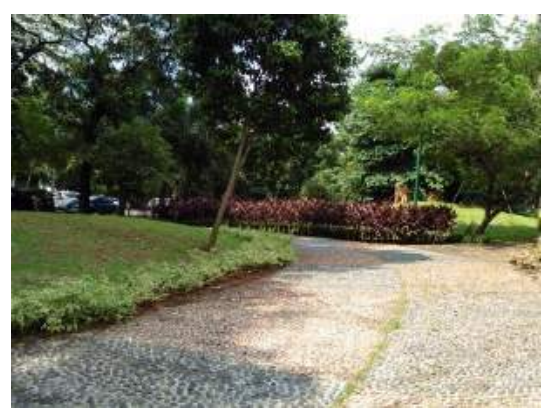

Lanskap 11 $(\mathrm{SBE}=36,10)$

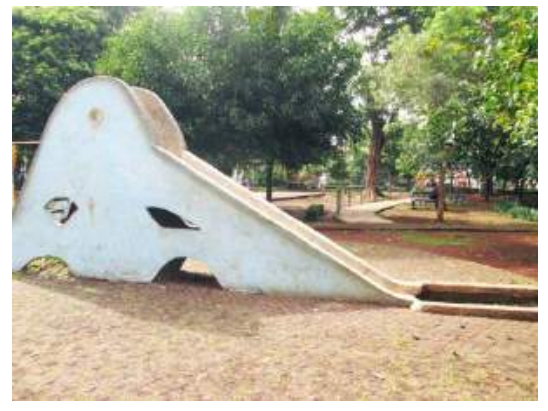

Lanskap 18(SBE=-104,24) 


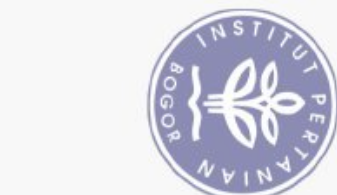

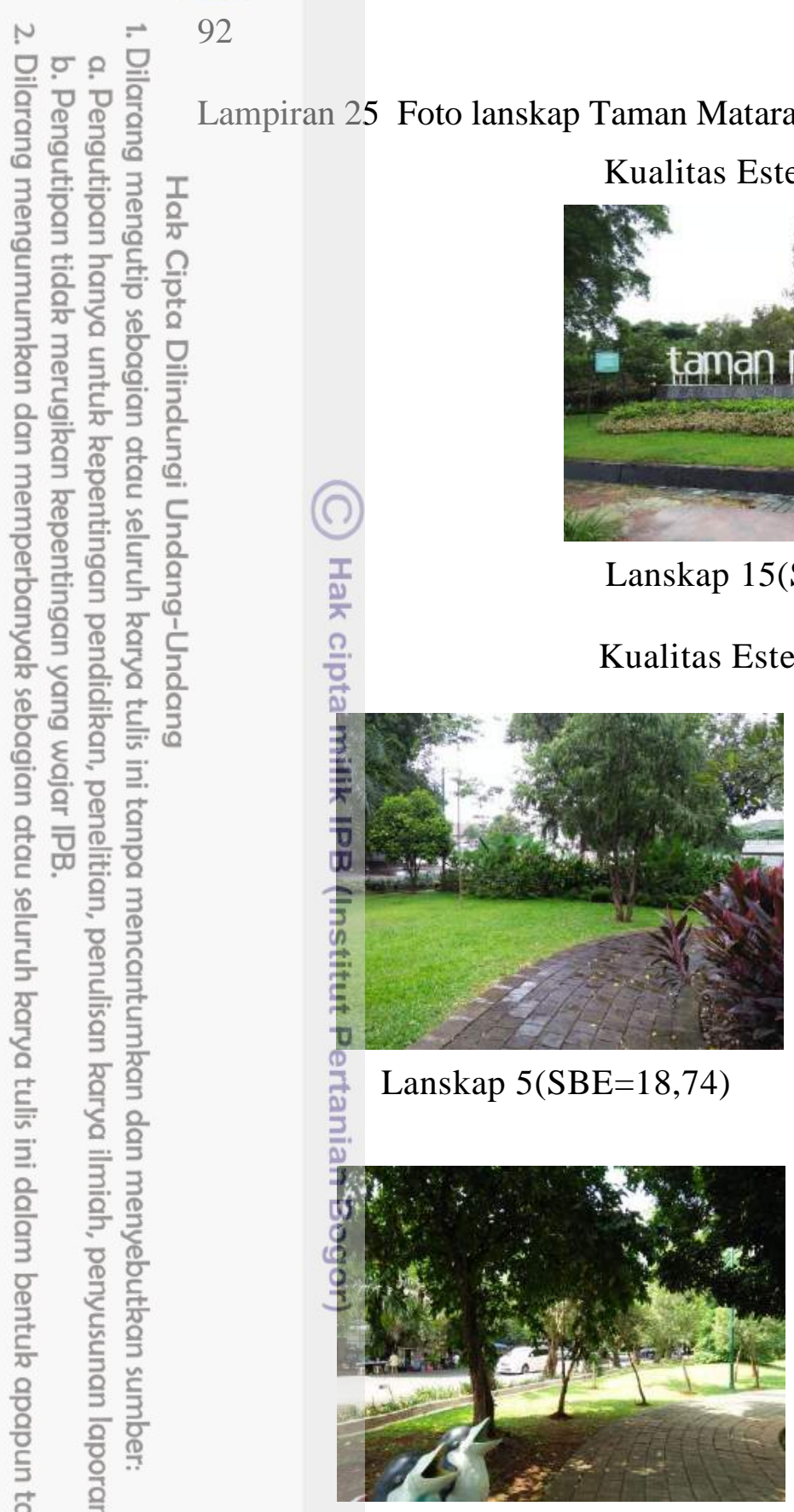

Lanskap 7(SBE=-7,85)

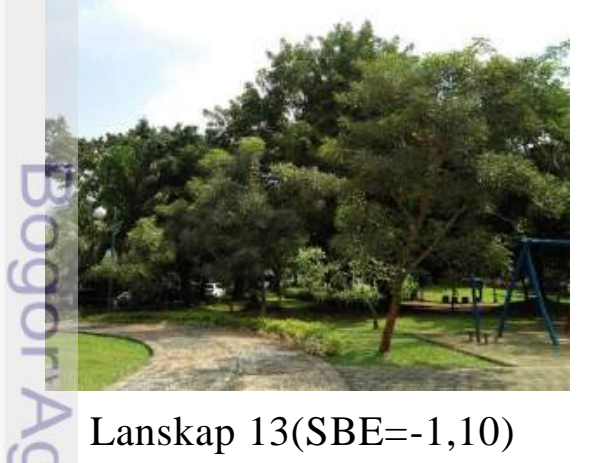

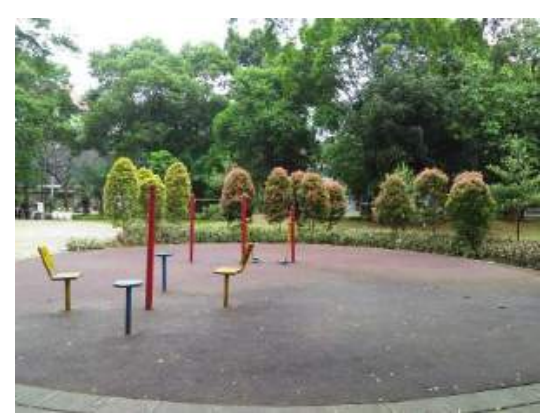

Lanskap 6(SBE=-6,42)

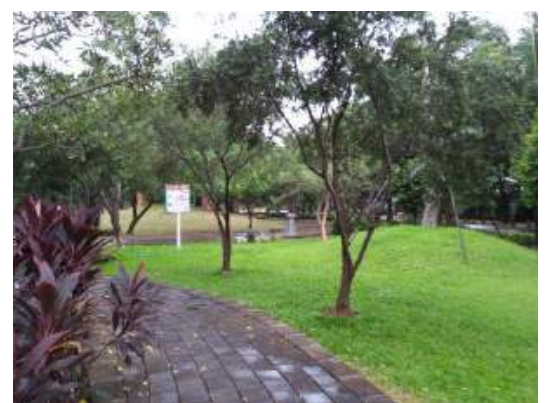

Lanskap 10(SBE=-3,26)

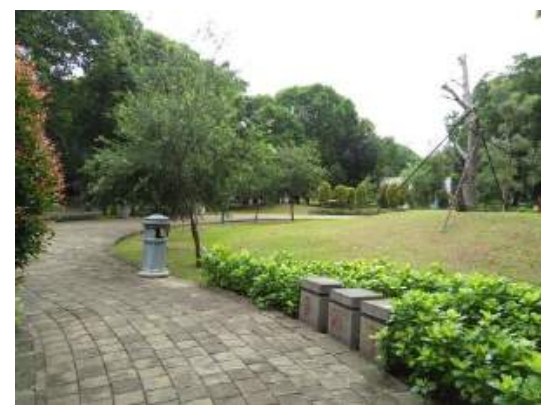

Lanskap 16(SBE=0) 
Lampiran 25 Foto lanskap Taman Mataram (lanjutan)

Kualitas Estetika Sedang

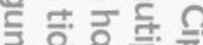

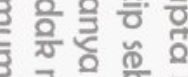

을 꼭 을을. 을

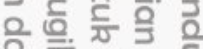

政震

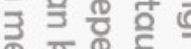

卷

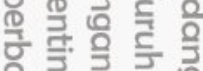

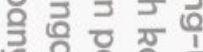

눈흘

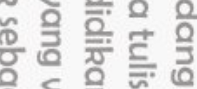

을. 읳

윽옹

웅 面

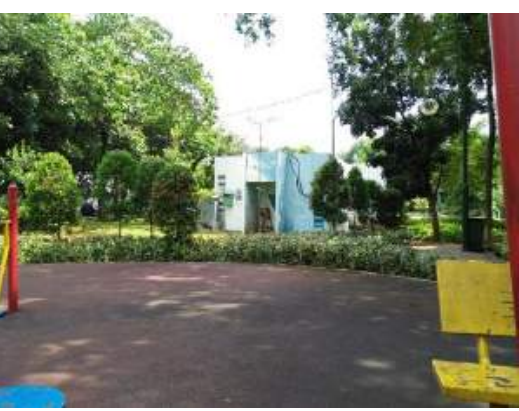

Lanskap 18(SBE=13,04)

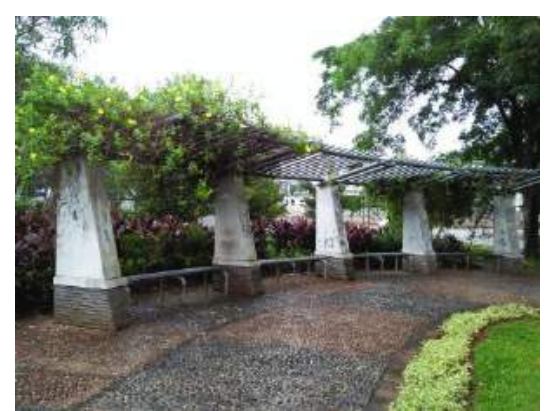

Lanskap 19(SBE=-9,50)

Kualitas Estetika Rendah

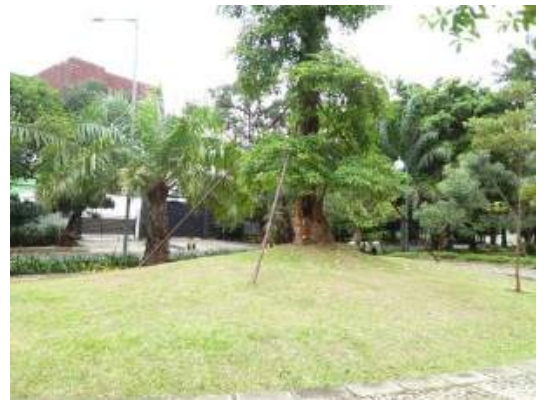

Lanskap 3(SBE=-26,37)

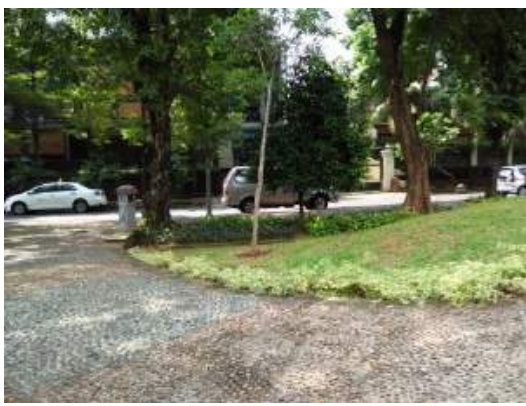

Lanskap 12(SBE=-80,23)

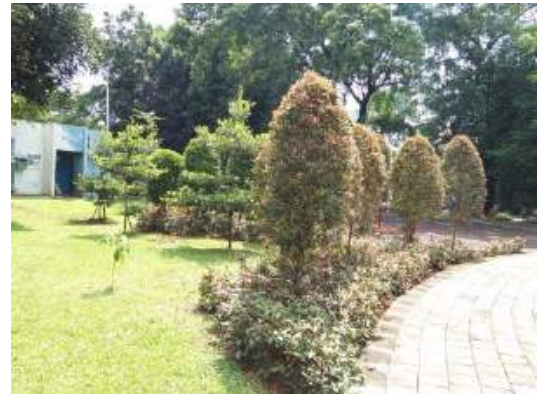

Lanskap 8(SBE=-25,15)

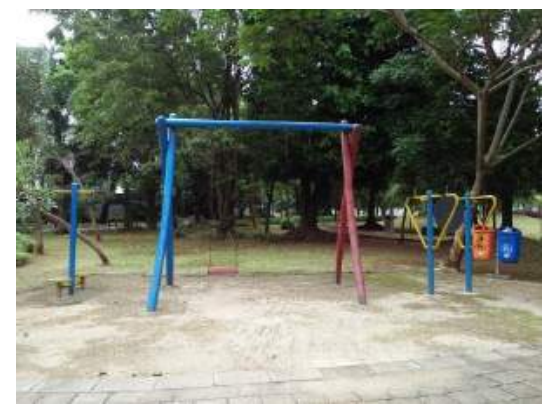

Lanskap 17(SBE=-112,82)

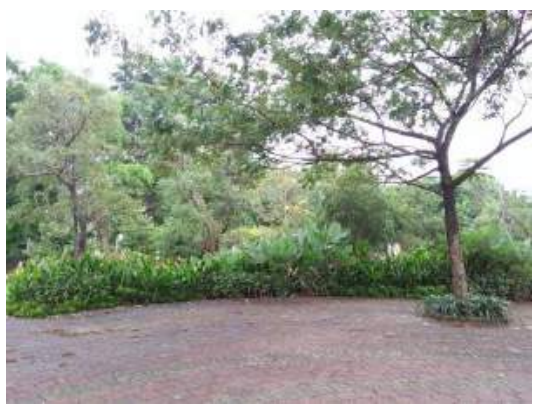

Lanskap 20(SBE=-77,71) 


\section{RIWAYAT HIDUP}

증 Penulis dilahirkan di Jakarta pada tanggal 13 Agustus 1994 dari Bapak ? Sugito dan Ibu Yumi Astuti. Penulis adalah putri pertama dari dua bersaudara.

Penulis mengawali pendidikan tahun 1998 di Taman Kanak-Kanak Al-Innayah Tangerang. Tahun 2000, penulis melanjutkan studi di Sekolah Dasar Negeri Kampung Bambu 1 Tangerang dan tahun 2006 penulis menempuh pendidikan di SMPs Sunan Bonang Tangerang. Tiga tahun kemudian, penulis melanjutkan pendidikan di SMA Negeri 23 Kabupaten Tangerang d.h. SMAN 1 Kelapa Dua - Tangerang dan lulus tahun 2012. Pada tahun yang sama penulis lulus seleksi masuk Institut Pertanian Bogor (IPB) melalui jalur Undangan dan diterima di Departemen Arsitektur Lanskap, Fakultas Pertanian.

Selẩma mengikuti perkuliahan, penulis pernah menjadi asisten praktikum mata kultăh Teknik Penulisan Ilmiah dan Dasar-Dasar Arsitektur Lanskap pada tahun 2016. Bulan Juli-Desember tahun 2014 penulis menerima beasiswa BBM.

Penulis j]̄ga pernah aktif sebagai staf Divisi Fundraising HIMASKAP tahun 2013-201-4, dan aktif dalam kepanitiaan yang diadakan oleh Departemen Arsitektuf Lanskap seperti Masa Perkenalan Departemen (MPD) Arsitektur Lanskap 2014, Fieldtrip Tropika 2014, Hari Pelepasan Sarjana 2015 dan staf Divisi Acâra Indonesia Landscape Architecture Student Workshop 2014. Selain aktif di Departemen Arsitektur Lanskap, penulis pernah menjadi anggota Pejuang Lingkungan BEM KM IPB 2013, staf Divisi Humas IPB Festival 2013, staf Divisi Acara IPB Art Contest (IAC) tahun 2013-2014, staf Divisi Publikasi, Dokumentasi dan Ticketing IAC 2015, dan staf Divisi Dekorasi dan Dokumentasi Gebyar Nêtisantara 2015. 